1970. Sog.

30.0.

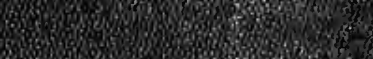

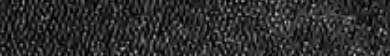

(2)

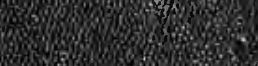

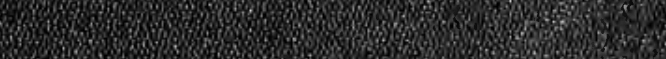

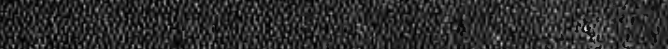
r. 3.

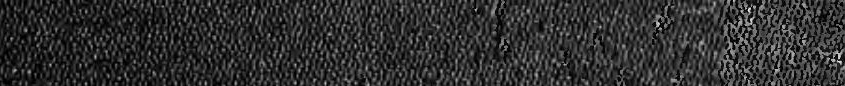
20.0.

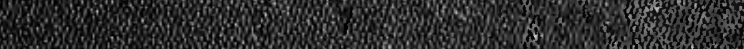

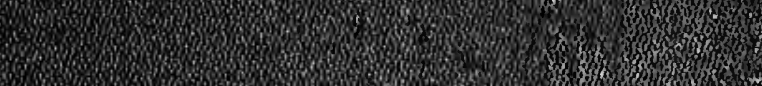

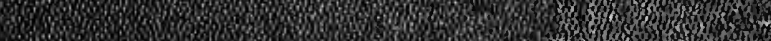
H. S.

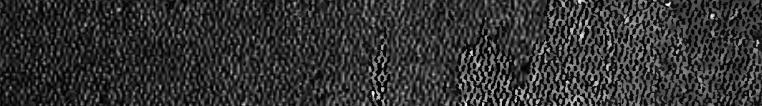
S.

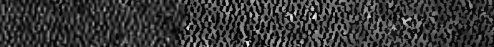

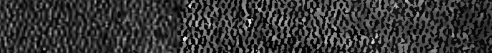

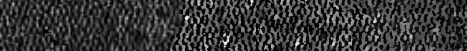
30. 3 .

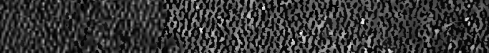

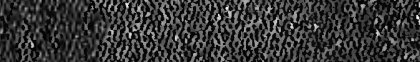
10.

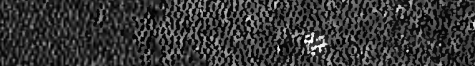

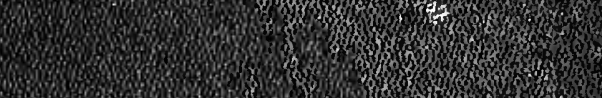

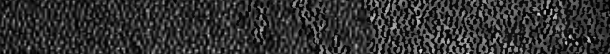
5.

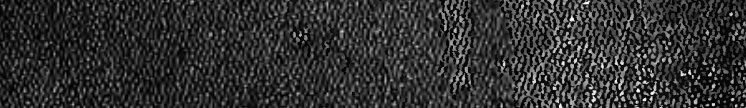

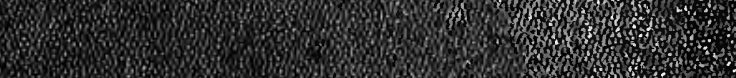

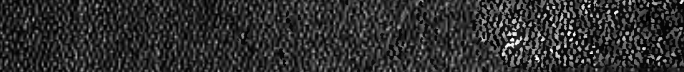
5.

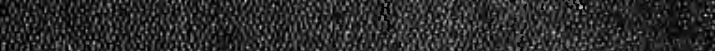

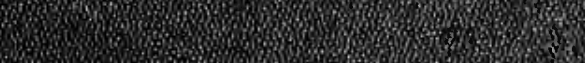

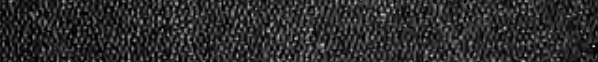
as

-

5 . W. 2.

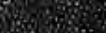




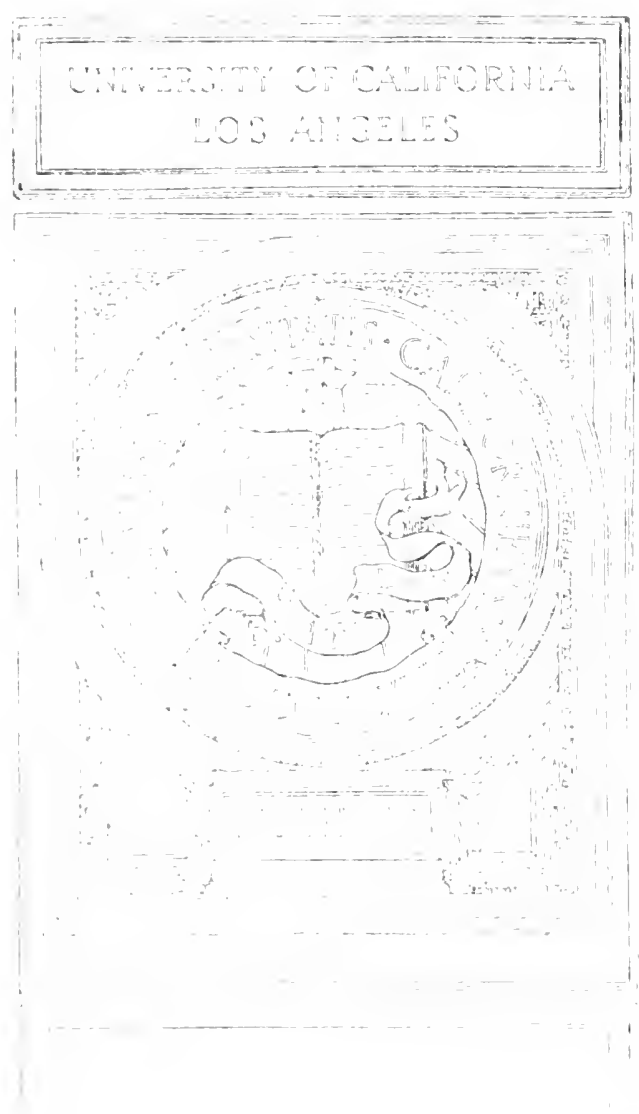






\section{THE}

\section{ADJUSTMENT OF WAGES}


ISY THE SAME AUTHOR.

ENGLISH ECONOMIC HISTORY AND THEORY.

Crown 8vo. I'art I. 5s. Part II. 10s. 6d.

SURVEYS, HISTORIC AND ECONOMIC.

Crown 8vo. 9s. net.

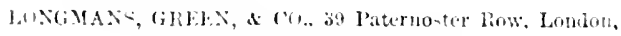

Sin lork and Bomlay. 


\title{
ADJUSTMEN'T OF WAGES
}

\author{
A STUDY IN
}

\section{THE COAL AND IRON INDUSTRIES OF GREAT BRITAIN AND AMERICA}

\author{
BY \\ W. J. ASHLEY \\ PROFESSOR OF COHMERCE IN THE UNIVERSITY OF BIRMINGHAM \\ LATE PROFESSOR IN HARVARD UNIVERSITY \\ SOMETIME FELLOW OF LINCOIN COLLEGE, OXFORD
}

WITH FOUR MAPS

L ONGMANS, GREEN, AND CO.

39 PATERNOSTER ROW, LONDON NEW YORK AND BOMBAY

1903 
IfI.

- 


\author{
M. A.
}

OF WHOM, HAPPILY, IN TWO CONTINENTS,

THE SAYING HAS BEEN TRUE:

9
岁

'COELUM NON ANIMUM MUTAT DUM TRANS MAPE CURRIT'

[' 'oelum non anirnum muto' d'c., an adaptation from Horace, was written by John Milton, at Geneva, in an album which is now among the chief treasures of the Hacvard Library.] 



\section{PREFACE}

THE eight lectures which form the text of the present volume were delivered on the Dunkin foundation at Manchester College, Oxford, during the first three months of the present year. I have thought it best in printing them to make no change in their form, but to content myself with amplifying the narrative or argument here and there by the addition of occasional notes. I have, however, appenderl a great number of illustrative documents. The rules of the English Conciliation Boards may perhaps contain some useful suggestions for the captains of American industry; while England has possibly something to learn from the American 'scales,' as for instance in the determination of machine-mining rates.

It will be understood that these lectures make no pretence to completeness: certainly they do not profess to 'solve' the problem of industrial organisation. They aim only at giving a general preliminary survey of existing conditions, which will make it possible for others to go farther and to come to closer quarters with concrete difficulties; and, although I cannot help) believing myself that the trend of things is in a certain direction, I hope this has not led me to distort or colour the facts. I can hardly expect to have escaped 
altogether the dangers of the professorial manner. But I would ask my readers to remember that it is necesiary to simplify one's statement for the purposes of exposition. I do not really forget that industrial affairs are exceedingly complicated, and that, with all our mechanism of boards and conventions, it is always human nature we have to reckon with-a nature so selfish and yet so generous, so suspicious and yet so sympathetic!

I regret that I have been able to give so small a proportionate amount of my space to the iron and steel trades. It was the limitation of my time and the absorbing and immediate interest of the coal situation, both in Great Britain and in the United States, which made me pass so hastily over the iron industry. But that industry presents features of its own which need thorough and systematic examination. Meanwhile the appended documents will supplement to some extent the one brief lecture on the subject.

The coal situation in Great Britain and in the United States has, for some time past, deserved the most careful and anxious attention. It is almost a commomplace to say, but in this instance it looks as if it were true, that Great Britain has reached a later stage in industrial development. Great Britain has reached the stage in whirh wages are detemined by negotiation between organised bodies of employers and employed. The problem before us here is to work out some principles for the guidance of the nesotiators. Anerica, on the other hand, seens to be just struggling on to the stage of corporate negotiation. Of course this opinion may he an old-world prepossession; it 
may be that America will come to present a new type, corporate in its control of capital, individualist in its treatment of labour; and the Steel Corporation will have many well-wishers in its experiment in this direction. But it is doubtful whether there is room enough in the industrial world for two principles quite so opposite; and an evolution of labour conditions in the United States substantially similar to that of England still appears the more likely.

There have been two events in the United States since these lectures were delivered which have the most direct bearing on the subject. The one is the Report of the Anthracite Strike Conmission, the other is the Merger decision of the U.S. Circuit Court. It is probable that the former will be regarded in the future as a distinct step towards the corporate negotiation of wages. With regard to the immediate and specific causes of contention, wages and the hours of labour, the Commission, as will be seen from the text of its awards printed in the Appendix, has simply granted to the miners one-lialf of their formal demands, exactly what they professed themselves ready to accept months before the President's intervention. It is noteworthy, indeed, that neither in the miners' statement of claim nor in the answers of the operators do we meet any of the arguments based on the price of coal which are so familiar to us in England. The questions raised in the claims and replies, and to which accordingly the Commission felt called upon to address itself, were only those of the relation of anthracite miners' wages to (1) ' the American standard of living,' (2) an alleged recent increase in the cost of living, (3) wages in the 
bituminous fields, and.(4) wages in comparable occupations. This onission of prices is the more remarkable because the Commission proceeds to create a sliding scale, following the price of coal, for the future regulation of wages. It is parallel with recent English practice that the scale starts with a recognised minimm (the wages of the present award), and that the Commission speaks of the absence of a minimum from previous scales as 'a confessed defect.'

But far more important are the Commission's utterances on the subject of 'recognition', for it is in this that the interest of the American situation centres. The Commission felt ' constrained to decline making an award which would compel an Agreement by the operators with the United Mine Workers of America,' on the ground that that body was "not a party to this submission' (or reference). Yet it felt that it was 'incumbent upon it to give some expression to its views on the general question.' Accordingly, it proceeds to express its belief that 'a working Agreement between employers and employees, embodying the doctrine of collective bargaining, contains many hopeful elements;' and it sets forth reasons for this opinion which will be found to harmonise with the general line of argument in this rourse of lectures. The reasons, in brief, are these: that unionism is the natural result of a 'community of thought,' and that to recognise the union when it actually represents the men is now coming to be simply 'at matter of business.' The Commission itself establishes a Boand of Conciliation representing the operators and miners of the antharite district only, and beyond this its award does not go. But it expresses the hope that, 
when the parties brought together on the Board have learnt to deal with each other, 'a trade Agreement between operators and an anthracite mine workers' organisation may commend itself to both sides.' It is evident that the Commission does not regard this anthracite organisation as necessarily quite separate from the United Mine Workers. There are two grave defects in the rules of that body which the Commission explicitly points out; neither of them, however, is inherent in a miner's union, and both could easily be remedied. Its recently revised constitution has given the districts of the anthracite region 'quite independent powers relative to the initiation of a strike, and has removed the chief objection of the operators.' Hence the Commission concludes, and its language is significant, that ' an independent and autonomous organisation of the anthracite mine workers in Pennsylvania, hovever affiliated, in which the objectionable features above alluded to should be absent, would deserve the recommendation of this Commission; and, were it within the scope of its jurisdirtion, the fourth demand of the statement of claim for collective bargaining and a trade Agreement might then be reasonably granted.'

The English reader who has followed the recent course of the negotiations in South Wales must be struck by the similarity of the problem presented to the trade union leaders in the two countries. The problem before the Miners' Federation of Great Britain and the United Mine Workers of America is to concede an 'autonomy' to a district-in the one case to South Wales, in the other to Eastern Pennsylvania-which shall sufficiently correspond to local conditions, and at 
the same time to retain an 'affiliation' which shall be a source of mutual support. That no solution can in the nature of the case be theoretically satisfactory need not hinder the adoption of a working compromise; and if such a compromise puts obstacles for the time in the way of an all-embracing national policy, its postponement will at any rate allow of the acquisition of some useful experience.

The other event to which I have referred is the recent decision of the U.S. Circuit Court of Appeals at St. P'aul, declaring illegal and an actionable offence the Nerger of the Northern Pacific and Great Northem Railroads in the Northern Securities Company. 'This decision has yet to be confirmed by the Supreme Court : but, assuming that it will be confirmed, I am bound to say that the rejoicing and alam with which the judgment has been received are both, in my opinion, mualler for. If it is greatly to the economic adrantage of two businesses that they should combine, the combination will ultimately be effected whatever the law may be. Should one method be judged illegal, another will be adopted; and if the owners of the businesser want to act together, or-in the last resort-if the owners of the one want to sell to the owners of the other, nothing ran prevent them short of the abolition of their lights of property. The result of previous attempts to legislate against capitalist combination has simply been to brimg about a closer form of union instead of a loosep one: and thomgh the recent Mereger case has aroused an unusual amount of excitement, from the maniturle of the interests involved and the fact of the I'resiclent's interposition, it cannot in the 
long run alter the economic situation. But "the long run' will involve some waiting on the part of the financial statesmen of America before they can eflect the combinations which they regard as urgently desirable, and they will have to do their work in the teeth of public obloquy-a situation which cannot but be painful to upright and public-spirited men.

Under these circumstances it may occur to them to reflect that combination among workpeople is only another form of that effort to lessen the disadvantages of competition in which they are themselves engaged: and that, at a time when they certainly want all the friends they can get, it may be politic to show a little more patience with the movement of ' organised labour.' And, on the other hand, it may occur to some of the unionists who now join in the outcry against 'trusts,' that there is no more reason for one railway to bid against another for freight than for one workman to bid against another for employment.

I have to express my gratitude to the many gentlemen who have furnished me with information. Among those who have been especially helpful I give myself the pleasure of mentioning Mr. Thomas Ashton, Secretary of the Miners' Ferleration of Great Britain; Mr. James C. Bishop, Enployers' Secretary of the Scottish Manufactured Iron Board; Mr. W. H. Bowater, coal merchant, Birmingham; Mr. Johı Graham Brooks, of Cambridge, Mass.; Mr. James Cox, Secretary of the Associated Iron and Steel Workers; Dr. Hemy Dyer, Vice-President of the Scottish Manufactured Steel Board; Mr. H. Ecrles, of 
the Briton Ferry Steel Company; Mr. Ralph M. Easley, Secoetary of the Civic Ferleration, Xew York; Mr. John Hodge, Serretary of the Steel smelter's' Assoeiation: Irr. Daniel Jones, Employers Serretary of the Midland Wages Board; Professor Lapworth, of Birmingham; Mr. A. K. Mr.Cosh, Chaiman of the Srottish Coal Conciliation Board; Mr. John Mitrhell, President of the United Nine Workers of America; Irr. Hugh Mnumo, Acting-Secretary of the Amalgamated Society of Steel and Iron Workers; Mr. W. W. Pearson, Employers' Secretary of the Srottish Steel Board; Professor Redmayne, of Birmingham; Mr. Albert Stanley, Miner's Agent for the Camock Chase; Mr. D. M. Stevenson, coal merchant, Glasgow; Mr. D. A. Thomas, M.P. for Merthyr Tyduil: Mr. John Wilson, M.P. for Mid Durhan ; Col. Carroll D. Wright, U.S. Commissioner of Lalbor'; Mr. Ralph Young, Secretary of the Northmberland Miners' Association; and the officers of the U.S. Geolowical Survey.

As to the mipe, it is neeserary to make this ubseration. The map which rommonly bears the mame -The coal Fields of the United States' is a geologival map only, showing the coal deposits of the country. But, as these deposits have muly begmu to be

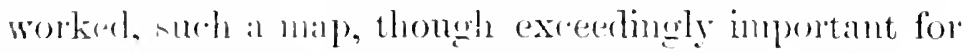
other purposes, is most misleading to the student of actual antemponary industrial conditions. Map) II. in this hook has therefore been constructed by the roughand-reaty poress of taking the geolowiral maps in the Tirenty-sireond Ammal lieport of the U.S. Geolonical Survery, and marking all the counties in the several 
States in which practically no coal was raised in 1901, according to the statistics in Mineral Resoures of the U.S., 1901 (U.S. Geological Survey), as needing to be left out. The residue indicates, of course only in a very rude and general way, the areas in which coal is being actually raised, and may serve until the U.S. Geological Survey gives us, as I hope, something better. Maps III. and IV. are taken, with some adaptation, from the Report of the U.S. Industrial Commission.

Edgbaston: May 1, 1908. 


\section{CONTENTS}

LECTURE I.

INTRODUCTION.

Great Britain and the British Empire . . . . . . .

The duty of the economist . . . . . . . . . . . 7

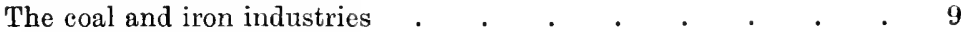

Trade Unionism from the psychological and administrative points of view . . . . . . . . . . 12

Unionism and Political Economy.$\quad$. . . . . . 17

\section{LECTURE II.}

British Coal Fields and Boards of Conciliation.

Description of the British Coal Fields . . . . . . . 22

Completion of the miners' organisation . . . . . . 30

Recognition of the miners' organisation . . . . . . . 32

History of Unionism : the Newcastle Period . . . . $\quad 36$

The Midland Period: Boards of Conciliation . . . . . 40

LECTURE III.

Prices and Wages.

The Minimum Wage $. \quad . \quad . \quad . \quad . \quad . \quad . \quad 45$

The Sliding Scale policy $. \quad . \quad . \quad . \quad . \quad . \quad . \quad .54$

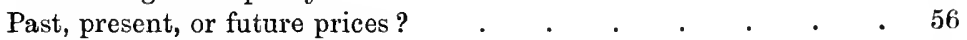

Prices and Sales. . . . . . . . . . 58

Prices and Cost of Production . . . . . . . . 58

Effect of the Sliding Scale on Wages . . . . . . . . 61

Present situation: 'Other Factors' . . . . . . 6.)

Wages and 'the Regulation of the Trade' . . . . . . 68 


\section{LECTURE IV. \\ General Rates ani) their Intehpretation. The Hovis or Labovis.}

The Constitution of the Poards . . . . . . . . . 72

The Chairman as Unpire . . . . . . . . . 75

The Joint Committees of Northumberland and 1)urham . . . 77

The Miner's'Agents . . . . . . . . . . . . 79

The Eight-Hours fuestion . . . . . . . . . . 80

\section{LECTURE V.}

Auerican Conl Fiemps and Joint Agremuents.

Description of the American Coal Fields . . . . . . . 87

General situation of the American coal industry . . . . . $\quad$. 90

'The Joint Agreement system in the Bituminous Fields . . . 95

The Interstate Agreement _ . . . . . . . . . 97

State Joint Agreements: the Illinois Agreement. . . 98

Competition and Unionism . . . . . . . . . . . 103

'The Central Competitive Field' and the admission of other States 105

Combination in the soft coal business . . . . . . . . 108

\section{LECTURE VI.}

The Anthracite Piromleu.

The recent strike . . . . . . . . . . . . 112

The position of the liailroads . . . . . . . . . 114

The results of eompetition . . . . . . . . 118

The attempt of $1892-3$ and its failure . . . . . . . 120

The recent unification . . . . . . . . . . . 123

Labour before and after 1875 . . . . . . . . . . . . . . . . . . . . 127

- Frecdom 'and industrial administration . . . . . 129

The strike of 1900 . . . . . . . . . . 130

The strike of $1902 . \quad$. . . . . . . . . . . . . 133

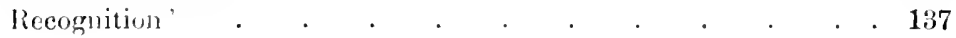

\section{LACTERE V'II.}

'The Iros Indestiry in (imbit Britain and America.

l'ritish lioards of conciliation . . . . . . . . 142

l'revalence of the Sliding sicale policy . . . . . . 146

Sume reasons therefor . . . . . . . . . 149

Anerica: the Amalganated Association and ammual scales . . 152

The stred corporation . . . . . . . . . 155

'The stritic of 1901 . . . . . . . . . . . 157

l'reent situetion: the alternative policy . . . . . . 158 


\section{LECTURE VIII.}

\section{The Legal Position of Trade Unions.}

England and America: resemblances and differences .

The Incorporation of trade unions: the proposal and its reception

in America . . . . . . . . . . 164

The proposal and its reception in Eugland . . . . . . . 169

Its accomplishment in New Zealand and New South Wales . . 172

The legal revolution in England: The Taff Vale Case . . . 175

Present obseurity of the law : the problem of Malice . . . 178

The law of Ageney . . . . . . . . . . . . 179

Effect of recent decisions in strengthening the mions . . . . 181

\section{APPENDICES.}

I. Coal Mining in Great Britain : Sourees of Information . 185

II. Coal Mining in Great Britain : Rules of Coneiliation Boards, \&e.

1. The Federated Distriets: Rules of the Conciliation Board 194

2. Northumberland: Rules of the Conciliation Board . . 197

2A. $\quad$ " Wages and Prices, 1879-1902 . . 200

3. Durhan : Rules of Conciliation Board . . . . 202

3A. " , J J . . . 206

3в. ," Wages, 1897-1902 . . . . . 212

4. Scotland: Rules of Conciliation Board . . . . 213

5. South Wales: Agreement and Rules of Conciliation Board . . . . . . . 218

1II. Coal Mining in the United States: Sources of Information . 230

IV. Coal Mining in the United States: Joint Agreenents, \&e.

1. The Interstate Agreement . . . . . . 232

2. Illinois State Agreement . . . . . . . 234

3. Indiana State Agreement . . . . . . 247

4. Olio : Scale for the Hocking Valloy . . . . . 252

5. Pennsylvania: Seale for the Pittsburg distriet . . 257

6. Passages from the Report of the Commissioner of Labor on the Anthracite Strike . . . . . . 262

V. Iron and Steel in Great Britain : Rules of Conciliation Boards, Sliding Seales, \&e.

1. Midlands: Iules of the Iron and Steel Wages Board . 268

1A. " Sliding Seale for Ironworkers' Wages .

1в. , A bi-monthly Report and Jeelaration of Wages . • · · · · $\cdot{ }^{\circ}$

2. North of England: Aunual Report of the Board for the Manufactured Iron and Steel Trade . . . . 280

3. Scotland: Rules of the Manufactured Iron Trade Board 285

4. , Rules of the Manufactured Steel Trade Board 
V. 4s. Seotland: Steel Board: Form of Statement of Case . 296

5. .. Rules of the Blast Furnaces Board . . . 297

6. Cleveland: Agreenent and scale for Hlast Furnaecs . 302

7. South Wales: liules of the Timplate and Slicet Mill Boird. . . . . . . . 305

8. North-Eisst Coust : Fules of the Board for Ironfoundries 307

VI. Iron and Steel in the United States: Joint Agrecments, \&e.

1. Statement as to the Sliding Seale and Wages, 1837-97 312

2. Agrements between Mamfiacturers and the Amalgamatcl Association . . . . . . . . . 323

3. Aceount of the functions of the Adjuster, . . . 326

4. Tinplate Agreement . . . . . . . . . . . . . 329

V1I. Report and Awards of the Anthracite Coal Strike Commission 333

\section{MAPS}

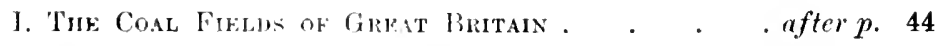

11. Sketen Mal sllowiri CodL AlEas actually worked

(1901) 1. remtin Strates of the American Union " 110

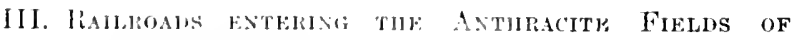

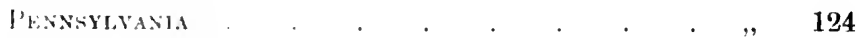

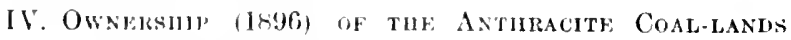

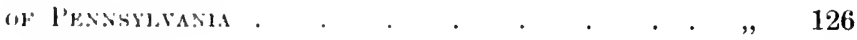




\section{THE}

\section{ADJUSTMENT OF WAGES}

\section{LECTURE I}

I NTRODUCTION

In is with extreme pleasure that I find myself once more face to face with an Oxford audience. Four years ago I had the honour to lecture before the University on an important topic in the economic history of England and her American colonies; ${ }^{1}$ and before another audience I endeavoured to explain some of the leading social characteristics of the great country which was then my home. ${ }^{2} \quad$ But it is fifteen years since I was last charged with a systematic course of instruction in this place. And, in those fifteen years, what vast changes have come about! The industrial supremacy-as that term is commonly employed-of Great Britain has passed away, never to return. Of course, Great Britain still exports a considerabiy larger quantity of commodities than any of its rivals, in proportion to the size of its population. But the extent and physical resources of

1 'The Commercial Legislation of England and the American Colonies, 1660-1760;' printed in Surveys Historic and Economic (1900).

2 'The Economic Atmosphere of America,' printed ibid. 
the United States are such that it only needed a corresponding growth of its population (with the given state of enterprise and knowledge of the industrial arts) to bring about a production of commodities far in excess of that of this little island. The decade from 1890 to 1900 may be regarded as the period when the United States began to forge alsead. This is very clear in the fundamental group of industries with which we are going to be concerned in this comse of lectures. The American production of pig iron (the raw material for all the iron and steel manufactures) exceeded ours for the first time in 18S9. It fell below in 1894; but since then, with the opening up of the enormous and cheaply worked iron-ore deposits of the Lake Superior region, it has been rapilly going ahead; and in 1902 it stood to ours in the proportion of $17 \frac{3}{4}$ to 8 . In the production of steel, after a neck-and-neck rivalry for many years (since, in fact, the introduction of the new Bessemer and Siemens methods in the early seventies), the United States finally left us belind in 1889 ; and since then its ficures of production luave beess soaring upwards, and in 1900 they were aheady twice as large as ours. As to roal, the foundation of our earlier superiority, we have been ontstripped in quantity of ontput since 1889, and (except when mining in America is suspended by strikes) we are likely to stay farther and farther belind; simply because America possessess wide coal tracts, in the sonth and West, which have havdly yed been tomdied. And-to take but a single instance from another aromp of occupations -while the cottom manufacture of this eromtry, our premier industry, has been ahmost stationary for thirtyfive years, the Unitul States passed us in 1900 in the amomint of cotton romsumed ly its mills, although the 
manufacturing development of the Southern States is only just begimning on a large scale.

If, then, we look forward to Great Britain as standing alone in the international comparisons of the future, we are compelled to think of it as occupying, in relation to the United States, and ultimately to Russia also (with its vast continuous empire in Asia and Europe and its evidently enormous physical resources), something like the position which Holland has occupied during the nineteenth century in relation to the Great Powers of Europe. But we may now reasonably anticipate that Great Britain will not stand alone; that it will constitute only the senior, and, for a long time, the wealthier member of a great British Federation. The time is passing when we could profitably compare the productive capacity of the insular Great Britain with that of the United States; the time has not yet come when we can compare with the United States the British Empire as a whole. For at present the British Empire does not form an economic unit. It has been within this same decade that the tide of sentiment in the several parts of the Empire, which just before was at slack water, or possibly even drifting toward dissolution, has begun to set in the direction of closer association. The result of my observation of the young men of Canada in the years $188 S$ to 1892 was a conviction that Canada was then slowly moving either towards union with the American Republic or towards independence. But what the missionary efforts of Imperial Federationists could not achieve, was brought about by the action of other governments. The Venezuela message of President Cleveland in December 1895 revealed a strength of British sentiment in Canada which certainly could not have been previously counted upon; 
and the refusal of the American Government, after the victory of Mr. MeKinley in 1S96, to orant Reciprocity to Canada, threw the new Canadian administration of sir Wilfrid Laurier hack on a policy of preferential tarifls with the mother country. Whatever may be thomght of the merit of preferential arrangements within. the Empire, or of the success of this particular experiment, it is now evident that the Canadian tariff of 1897 opened a new period in the history of the relations between England and her colonies. Meanwhile it has been the appearance of the Great Powers in the Pacific: - of Germany in New Guinea in 1SS4, at Kiao-chau in 1897, and in the Caroline and Samoan Islands in 1899. of Russia constructing her railway at Vladirostok in 1891 and occupying Port Arthur in 1898, of the United States at Hawaii in 1894 and the Philippine Islands in 1898-which has destroyed the isolation of Australia and indicated to its people the practical value of the British comnection. Of the effects upon the Empire of the South African war it is too early to speak: but one thing is rertain. The real obstacle to greater british mity was the weakness, or absence, of rommon daily interests. But now, all over Canada and Australia, there are thousands of men who will look hack. as to the most interesting period in their lives, to the tine when they served side hy side with men from England and all other parts of the Englishspeatimy Empire. The prospect of closer union is enconsanger and. if the mion is to be a permanent one, it will involve ceomomic as well as political cooperation. 'The possibility of ntilising for English manufartures the iron ore of Newfoundland or the rotton of West Afriar will berome something more than a commercial question if the imperial sense con- 
tinues to grow more acute. And yet while this is soand the changed situation is one of the most remarkable phenomena of the last fifteen years-I shoukl like, as one who has made it his business to keep in touch with the sentiment of one great British colony, to drop a word or two of cantion. That the British Empire will hold together, and, holding together, that the union will grow closer-for relations camnot remain stationary -is still (we ought to realise it) rather a matter of hope, of not-too-confident anticipation, than of comfortable assurance. And the future political structure must be constantly conceived of as a free fecleration of selfdetermining peoples, each of whom chooses to associate itself with the parent country because it does itself spontaneously desire to do so. We in England must cease to talk, we must try to cease to think, as if we had made the colonies, and the colonies owed us a debt of gratitude. The colonies feel, and with some justice, that they have made themselves. And if we remember how large a part of the people of Canada and Australia are descended from working folk who left England and Scotland and Ireland simply because they could not make a living here, we cannot be surprised at an absence of grateful emotion, an occasional acerbity of utterance, which would shock many Englishmen if they really knew.

To descend from these high matters of the fate of nations and come to lowlier topics, the fifteen years have witnessed a new start in economic discussion and investigation, and a noticeable widening of the horizon of thought among those persons-far too few-who give any serious attention to economic problems. We have become aware in England that there really are eminent economists in Germany, and their treatises are respect- 
fially received by our writers. When I was a young tutor in ()xford and bean to talk about Gustar Schmoller. I suspect some of my fremols almost supposed that I had invented him. Since 1891 the reproach has been removed from England of not possessing a single scientific jomrnal dealing with economic topics; and the surcessive volumes of the 'Economic Journal,' edited by l'rofesson Edgeworth, have set before us a wrat deal of valuable material, in certain directions at any late of social inquiry. Since 1893 the industrial statistics at the disposal of the public have been notably enriched by the establishment of the Labour Department of the Board of Trade. In Mr. Claters Booth's 'Iabour and Life of the People,' which began to appear in 1889 , we have obtained a store of fresh information, and, what is of more signifcance, an eximple of statistical method such as would do homone to any country, and such as no private person in any other "omutry has ever produced. In the fietd of ofunal theory, the only ontstanding event since the appearance of Mill's 'Principles' in 1847 had been the publication of Jeroms book in 1871 ; and Jevons' influence was rery limited. In oxford the ordinary man lived on Fawrett; thongh his reign was bemg threatened i,y the interesting Inerion text-books of Gemeral Walkel. Sot till Ls:0 did we obtain in Professore Marrallis first rolume a work of amplitude, dignity, and themententes worthy of the subjert and of its beat tratitions. Tlowrere opinions may differ as to the formal arkepuary of its methox, there an be no londer that it represents a new departure in economic sperentations, it llew rentre romal which the younger theorist ma! work with satisfartion. And, finally, in

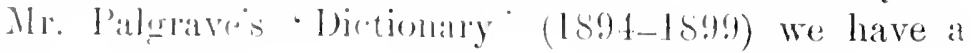


convenient work of reference, fit to be compared with its German and French rivals, and, if inferior to them in some respects, incontestably superior to them in others.

Such, then, have been some of the changes since I last gave a course of lectures in Oxford. And yet I cannot but feel that the opinion which I then held with regard to the duty of the economist is equally valid to-day. My subsequent experience has confirmed my old feeling that, for all save those exceptional individuals who have a gift for abstract speculation-I recognise that it is a real gift, but I am sure that it is very exceptional-the chief duty of the professional economist, and of the serious student capable of doing work for himself, is the ascertaimment of the facts of actual life. These facts need to be classified, and brought under generalisations: they must not be thrown before the reader in a shapeless heap, but grouped so as to bring out their inter-comnection; and, in order that the results should produce an impression on the reader, they must be presented in a certain artistic form. I grant that a nere grouping of observed facts in the light of careful common sense will not of itself carry one all the way one would like to go. Sooner or later it will become necessary to resort to more or less abstract and dechuctive lines of reasoning in orler to bring out the full meaning of the facts. But I an convinced that much, very much, can be done before this necessity arises; and that one reason why the very considerable speculative ability of English economists has so often the appearance of beating the air, bombinans in varuo, is that it has not had furnished to it sufliciently concrete statements of actual groups of circumstances. Perhaps I may illustrate what I mean by calling your attention 
to the state of our economic literature. There does not exist a single treatise describing the organisation and recent development of any one of the great English industries-iron, cotton, woollens, engineering, or shiphuilding. No adequate work has yet been written on the competition of foreign with English wheat. On hardly any of those lancel questions of policy which confront business men who take time to think-questions which they approach fiom the sicle of immediate selfinterest, but which are nevertheless of vast social importance--is there anything more to be pointed to than fugitive masazine articles. I trust that the creation, now begiming, of rourses of higher commercial education in the younger English universities, and the necessity laid uyon their teachers to come into closer contact with business life, may fill mp these deplorable and almost scandalous waps: and by giving the abstract thinkers something, if I may say so, to put their teeth into, turn out, even for them, blessines in disguise. But I do not limit my adrocacy of such work to this possible use of it. I believe that, withont any very subtle reasoning, a mere "xposition of existing conditions will, in many a rase, be of oreat assistance in the business of life.

It nsed to be discussed wamly whether Political Economy shomkd lo regarded as a science or an art, or as both; whether it should be conceived of as a purely oljucetive presentation of the roonomic forces actually at work; or whether it should, in exchange or in ardition, Je conceived of as indicating the conse which wejety meglet to follow to reach a certain end. The discussion was not a roly profitable one; and yet the distincoton is one which it is ssential to keep in mind. The ecommist, whether he wills it or no, cannot stop at the oljective presentation of facts: human nature is 
too strong for him. But there will necessarily be as many economic arts as there are social ideals. Science, however, in the narrower sense, as the statement of what is, can only be one. And it is surely not too much to hope that a time is approaching when good observation and sound generalisation will be recognised as such from whomsoever they may proceed. All that is necessary is that we should keep the two things, fact and ideal, sufficiently apart in our minds; and that it should be reasonably clear at any moment whether we are expositors or advocates.

I have chosen the allied group of industries which have to do with the production of coal, and of iron and steel, as materials and not as finished conmodities, for a number of simple reasons. In the first place, on account of their magnitude. The persons engaged in them number somewhere between an eighth and a ninth of the income-earning population of Great Britain. They are considerably more numerous than all those engaged in agriculture; and if we allow for the persons dependent upon them, we are probably not far wrong in attaching to the industries in question more than one-seventh of the entire population. Coal, iron, and steel, moreover (not including therein machinery and ships), furnish between them one-fifth of our total exports; and though each of them comes far below the seventy-three millions' worth of cotton goods in the list of our exports, coal and iron and steel are next in order, and with their thirty-one and twenty-five millions respectively are far in advance of the woollen exports, which follow behind with nineteen. These are the figures of 1901 .

Not only are the industries great in themselves: 
they include an even greater proportion than their numbers would imply of the workmen organised in trade associations. 'The subscribing members of the miners unions alone are one-fourth of the total number of trade unionists in the country-almost half a million in 1900 out of less than tro millions; they are more than twice as many as all the members of the textile unions put togetler.

This suggests the second reason for giving these trades our special attention. As the largest of industries, they exhibit in its completest form that condition of things which has been characteristic for some time now of all the lare industries of the country: the complete substitution of collective or corporate bargaining about wages for indiridual agreement. While London journalists have been discussing recently the question whether collective bargaining is a good thing or no, as if it were still a matter of choice, the people engaged in these great staple trades have gone on following the deep-roted habit of many years as a matter of rourse. To riscuss the desirability of collective arrangement in the coal inclustry of England is something like discussing the desirability of the atmosphere : it is the enviromment to which it is accustomed, and which all parties take for granted. When a distinguished (oxford tutor long ago became a disciple of Auguste Comte, and berm to preach the doctrines of Positivisn and talk about the 'proletariate, it was remallked that his knowledpe of the 'proletariate' was derived exchusively from the observation of his college serout. I have sometines thought of late that the notions of the labouring alasses entertained by the barrister who write for the papers are derived from their contemplation of the laundresses in their chambers. 
And, speaking seriously, London is a very bad place for the observation of Trade Unionism. London is, in the main, a place of small trades; and it is in the small trades that unionism presents the greatest difficulties to the economist and the moralist. As I shall hope to indicate, the difference between large and small industries is something more than quantitative: in a sense it is qualitative; a difference of kind as well as of degree. And before going further I wish to make it clear that by my statement that collective wage arrangement is the long-established method in the greatest industries of the country, I by no means wish to imply that therefore the method of collective arrangement is desirable in, or even applicable to, all the industries of the land. The question which confronts many an employer in a small trade who seeks to do his social duty, whether or not he shall encourage the growth of mionism in that trade, is-putting on one side altogether pecuniary considerations-by no means an easy one, and must be dealt with differently in different cases. The circumstances of the trade and the character of the union may be such that it is the employer's duty to treat the union with cool indifference: it may even be his duty to fight it with all his might.

But we are not now concerned with cases of this kind. We are dealing with industries in which tens of thousands of men are employed; in which-in England at any rate-the unions obviously represent the great body of the employed; in which for many years past they have been formally recognised by the employers; and in which the officers of the trade societies are regularly negotiated with by the representatives of the employers, not as a matter of condescension, or charity, or courtesy, but as a simple matter of business. I shall 
show by-and-by to how large an extent this is already coming to be the case in the United States, in spite of a widespread opinion to the contrary. And this method of collective arrangement has led universally in England-is begimning to lead in America-to the institution of a certain mechanism for adjusting the remuneration of labour. It is this mechanism in its several forms, and the profomndly important questions of prineiple which are being brought to the front in the course of its working. which will form the main subject of the following lectures.

But, before approaching our proper subject-matter, some general observations may not be out of place. In what I shall say, it will be remembered that I have in my mind whefly the large staple industries of the country. Trade Unionism has been too exclusively looked at hitherto from the points of view of abstract ethics or of abstract economics. It onght also to be looked at from the points of view of psychology and of business administration. And first as to the psychology of the matter. Unionism is only an example on a large scale of the natmal gresariousnes of similars. This is a very deep-seated human tendency, as deep as, or deeper thais, the pursuit of self-interest: a tendency, indeed, wider than humanity, for do not "birds of a frather flock tocether" The best known of American sociologists has based a whole system on what he calls "the consecionsness of kind. I doubt whether this is quite sufficient for a whole system; but it is certainly an illuminating thom the more or less distinct conscionsmess that we are like some people and unlike others is the ultimate cause of all the attractions and repulsions of soejal life. And in no country is the 
operation of this force more universal than it is in England to-day. Scarcely does a profession, however specialised, come into existence than there springs up an association of its members, with offices, subscriptions, and meetings. It was only the other day that the County Councils were given the Whisky Money to spend on Technical Instruction: there is already an Association of Dilectors and Organising Secretaries for Technical Education. In the cases we are now considering, there are tens of thousands of people working under the same conditions, with the same standard of living, influenced in their income and expenditure by the same decisions of their employers. Of course they come together; they talk over their affairs; an esprit de corps, a class feeling, inevitably arises. And in the case of the miners-and only in a less degree in the case of some of the groups of iron-workers-the employment is of such a nature that unless men enter it young they will not enter it at all; and therefore the occupation is largely hereditary. Moreover, in the case of the miners -and again in less degree with some of the othersthe occupation is generally the sole or main industry of the neighbourhood : the bulk of the population is directly or indirectly engaged in it. And thus, as the Majority Report of the Labour Commission pointed out, the miners of the several districts (and the situation is not entirely peculiar to the miners) form what that report calls a 'natural craft.' They would constitute an inchoate or potential trade union, even if no formal union existed. This explains the circumstance that a common policy is sometimes pursued, the hardships of a strike willingly endured, by a considerable fringe of persons in a district who are unconnected with the union. Of course there may be a certain amount of terrorism, 
but it is often quite mnecessary. The mnion may contain only the more provident, or altruistic, or ambitious, or turbulent (which yon will) of the people employed; but, for all that, it may fairly express the sentiment of the whole popmlation. And that is why it has been sometimes fomd of late in America that the best means to get people into the mion is to organise a strike: simply because the mion is felt to be representing a cause which thousands outside have at heart. From the psychological point of view, then, trade unions are not a matter of wonder: it would be a matter for wonder if they did not exist.

Look now at the thing from the administrative point of view. Manufacturing on a large scale-what the Germans call Grossbetrieb (it is a pity we have no neat term for it)-neressarily involves common rules. In the old domestic industry work could be carried on when the workpeople liked - each cottage weaver, each village blarksmith, could begin work and leave off as he chose. But in the modern factory, works, yard, mine, where many men are employed, whether with much or little machinery, it is administratively impossible to treat every man as an individual. He must be subjerted to common hours and other general regulations. This is almost as true of the payment of wages. Introdure piecework as much as you please; pay, if you like, a few peeuliarly skilled or trustworthy men a higher time waye; for the mass of the men, when many are employed, there must be general 'rates' of wases: a separate haresain with every man and a separate scale of reckoming for each are atministratively impossille. But what is necessary in a sinerle business is natural in a whole industry. Besicles the psychologrical influences disposing employers towards what 
Adam Smith long ago called their 'tacit combination,' influences which are strong in proportion as the employers are necessarily brought together at market day, in social intercourse or otherwise, there is the weighty consideration that a conmon policy on the part of all the employers, the observance of the same standards or rates of wage, greatly lightens the toil of conducting business operations. The employer has the task of marketing his product on the one side, and of providing capital, and therewith the technical requirements of the process, as well as of superintending the labour, on the other; it is usually a great nuisance if he has, at the same time, to worry himself as to whether a rival coalowner or manufacturer is paying the same wages or getting his labour more cheaply. Looked at from the employers' point of view, a common rate of wages is mainly a labour-saving device. Of course there are employers, here and there, who break away and pursue a wage policy of their own: this is more often done in America than in England. But, speaking broadly, a common rate of wages commends itself to the employers of a district for administrative reasons, and would do so if there were no mions. Such a method as the sliding scale, making wages vary automatically with the price of the product, was introduced, it would seem, in the iron industry by the masters some time before there was any joint agreement with the men. But it is evident that the subjection of the men to common rules of work and common rates of wages vastly strengthens the sense of identity of interest on their part to which I have already referred. And the step is a short one, though often difficult to take, from common rates to common agreements.

But it follows from this that the greater uniformity 
there is in the labour required, the easier it is to agree upon common rates; and the greater the number of varieties of service performed in the same establishment, the more diflicult it is to make a general rule. An old rate may be clung to by the men after the old uniformity has disappeared; and the resistance to a necessary modification of the scale may induce the employers to declare that collective agreement must be replaced by individual baronining when the new variety was. after all, not incapable of reduction to a rule, though a rule of more intricate application than the old one. Something like this was apparently the position of aflairs at the time of the recent great engineering strike. The industries we are now going to consider are marked hy certain broad similarities in the kind of labour-so that the work of the herrer or the puddler is mun the same wherever he is employed-together with innumerable divergencies in detail. Yet it has been found posible, as we shall see, to regard all these diverencies as variations of measurable degree from certain recognised types, and to derise means for applying the same scale to the several particular cases with a very considerable neasure of success.

Unions exist for many other purposes than to obtain good wages. They have heen among the most powerful forces working in the direction of the limitation of the hours of labour. They have used their influence to secure proper provision for safety; to diminish the employment of rhildren: to serme compensation for arcidents. And nost of them perform to some extent the provident functions of firmolly societies. But their main purpose has been to seremre as high wages as possible; and, after all, the amount of the weekly income is the most inportant single question in the workman's 
industrial life. Now I do not intend to discuss at any length the theoretical question of the possible influence of unions on wages. I would refer you to the excellent, though not very easy, chapter on the subject of Trade Unions in the recent editions of Professor Alfred Marshall's 'Economics of Industry.' You will there see how impossible it is to arrive at one sweeping judgment applicable to all unions or to unionism as such. There are unions and unions; and while some unions may be harmful to the community, of others, such as those we are about to consider, the 'confident' judgment of a man like Professor Marshall is that 'on the whole they facilitate trade.' But there are three observations $I$ might briefly make :

1. The prevalent middle-class and journalistic opinion that in some way unions are necessarily opposed to the 'laws of Political Economy,' is a survival from the economics of seventy years ago. Every English and American economist of eminence takes care to point out that in the wages bargain the isolated workman is usually at a disadvantage in comparison with the employer. Professor Marshall's way of phrasing it is that 'the normal force of supply and demand' will not act freely if the contracting parties have no 'reserve price.' The primary significance of a union, according to him, is that it enables the working-man to have a reserve price. Professor Clark, who is perhaps the acutest economic theorist that the United States have yet produced, puts it in this fashion: 'a slight excess in the number of labourers' puts a 'lever' into the hands of employers which may enable them to pay a wage inferior to 'the productive power' of the men they engage. Such, he says, is 'the original and generally sound 
reason advanced in justification of the organisation of labour.' I I do not refer to these opinions as positively authoritative; but simply to remove an obstacle in the way of the unbiassed consideration of the subject. It is surprising, but it is true, that one is still constantly told, or finding it implied, that unionism is against Political Economy.' Usually this is supposed to reflect discredit on unionism; occasionally it is asserted that this is 'so much the worse for Political Economy.' But if Political Economy is taken to mean what the chief economists of the last two generations have actually been teaching, the opinion indicates simple ignorance.

2. My second observation is that in any particular contention the economist is no more able than any other shrewd observer to determine offhand the exact point at which wages should be fixed. What economic reasoning has done has been to indicate in a very general way the limits within which the rate of wages can move without being detrimental to the particular industry or to the community at large. But the application of this general reasoning to a particular case is extremely diflicult even in relation to the fortunes of a single industry. It involves the possession of certain data which are far from easy to obtain. Wages, let us say, are fixed mululy high when they anse profits to fall below those obtainable in other rqually attraretive fields of investment. They are fixed unduly low when they fall heneath the average wages in other industries, due reand being paid to the other advantages or disadvantiges of the occupation. But whether this point has on has not been reached in profits or wayes is not remlily determined : rertainly it

Political sticne enerterly, xvii. (190:), 561. 
would be unsafe to accept the assurances of either party, however honest they may be, without examination; and in most instances it would be impossible, even with the utmost care in forming an opinion, to arrive at more than a strong presumption, simply because the necessary information is not accessible. And when we come to the wider question of the effect of a certain rise or fall on the community in general, the problem becomes even more har? to determine. We cannot always be conficlent what will be the ultimate real incidence of a new burden on an industry-whether it be a tax or a higher cost of labour. If we decide that it falls on the consumer, we cannot be sure in all cases whether this will be hurtful to the community or not, and if hurtful, to what extent. If we decide that it trenches on profits, we cannot confidently predict the effect of a decline in the rate of interest on the accumulation of capital or of a decline in the reward of management on the supply of business ability. I do not say this to depreciate the value of economic reasoning: even the general and preliminary considerations which will be found in the standard text-books may have a useful effect in suggesting caution and discouraging extreme riews. But they do not provide, nor do they profess to give, definite and immediate solutions. And it must be remarked that, so far as I know, no attempt has yet been made, by any competent investigator, to get to close quarters with the economic issues involved in any notable wages dispute while the dispute was still going on : the nearest approach to it has been in the adjudications of arbitrators in the northern coal trade. But these gentlemen have commonly introduced general economic considerations only incidentally, if at all ; for they are usually prudent enough to give their judgments without their 
reasons. There are, indeed, a few interesting and probably more or less true estimates of the merits of a strike, after the strike is over; but that is hardly so useful.

3. My third point is that all the unions in the coal industry, and all but one of any importance in the iron industry, are exempt at any rate from one criticism often brought against trade unions, whether with justice or not. If the insistence upon a standard time wage pulls all the men down to a dead level and checks production-how far this may be true I cannot now consider-nothing of the kind can be said of the piece wage of the miners, and of the iron and steel workers. The one considerable exception is the Society of Ironfounders, which clings to a method of time-work which is probably quite out of date. ${ }^{1}$ But this is quite a small society compared with the great miners' unions. And there, as we shall see later, the chief ordinary work of the officials is to apply piece-work rates.

4. One final remark. We cannot find absolute logicality in economic organisation any more than in political. Fortunately we English people do not expect it in political organisation. If it were conceivable that workmen should all be content to submit to the paternal rule of their employers, or even yield under protest to the terms they imposed, it night be practical politics to raise the cry, 'Down with trade unions!' But a century's experience has shown that that is not feasible -I am speaking of the staple trades of the country; and almost everyone who has given the matter serious attention, including the majority of the last Royal Commission of Labour and all the economists, has pointed to the obvious fact that the only practical alternative to.

1 Webb, Industrial Democracy, 302. 
strikes-peaceful collective bargaining-depends for its efficacy on the existence of strongly organised unions. But strongly organised mions, though they are indispensable instruments for enforcing treaties, are powerful weapons of attack. We need not cover up the fact that employers are often compelled to yield more than they honestly think to be just, because of the fighting power of the unions engaged. This puts the employer in an awkward moral situation: it is almost more than can be asked of average human nature to demand that he shall rejoice at the growing power of a union; and yet, unless it is strong, it cannot effectively maintain the peace. I cannot help thinking that industrial organisation is something like the present British political system. The ministry of the day always maintains the wisdom of its policy : if we listen only to its members, it is hard to understand how, on any particular measure, anyone who is not either a knave or a fool can possibly differ from them. And yet all the time each ministry knows very well that the existence of two parties is necessary for the working of our political system. It even grumbles at the weakness of the Opposition as harmful to the country, and indeed to some extent awkward for itself, while at the same time it argues that there is nothing the Opposition ought to oppose. This is the inner illogicality of the two-party system which prevents its adoption by our more consecutively thinking Gallic neighbours. But we manage to get along, nevertheless, with our parliamentary government; and similarly the strong men, like Sir David Dale, who have to represent the employers' cause in the North, accept the situation as they find it and make the best of it. 


\section{LECTURE II}

BRITISIL COAL FIELDS AND BOARDS OF CONCLLIATION

Ix order to realise the present situation in England, it is necensary to besin with the actual geographical position and the physical characteristies of the several coal fiekls. The map at the end of this lecture represents the districts where coal is now actually being worked. It represents. therefore, also the districts inhabited by a mining population; it being understood that the mining population is much thinner in some parts than in others. and that here and there their dwellings extend for two or three miles beyond the alctual boundaries of the coal field.

1. Though it is not the largest of the fields, in area, output, or number employed, we may take the Great Northern or Veucustle Field first, because it has been worked much longer and has historically been by far the most important until a comparatively recent period. Its output in 1901 was over 4.5,000,000 tons, and it gave employment to $1.5 .5,000$ persons. The coal is easily worked, and most of that rontained in a seam can be taken ont. Owing to its proxinity to the sea it is easily shipped; and the greater cheaphess of water carriage long gave it an advantage in the London market. Of the $4.5,00(0,0(1)(1)$ tons of total output in 1901, more than 8 millions were shipped coastrise to English ports; while $13{ }_{4}^{1}$ millions were exported. Half the whole output, that is, was sent away by water 
to distant and competitive markets-markets in which any prolonged failure of supply would lose the trade (at any rate for the time); its place being taken, in the case of London, by the Midland coal; in the more important case of the foreign market-practically the Baltic-by the coal of Westphalia. This is a fact to be constantly borne in mind in examining the trade policy of the northern miners. The other half of the northem output is used in the domestic consumption and still more in the manufactures of the districtespecially the engineering works of Nerrastle, the blast furnaces of Middlesborough, and the puddling furnaces of Darlington.

But though this field is the oldest in rorking, and it still stands second both in ontput and number employed, it is gradually becoming of less relative importance in comparisous with other fields. Its output is increasing, but only slowly; and its miners form a slowly decreasing percentage of the total number employed. Thus five years ago it was $20 \cdot 3$ per cent.; now it is $19 \cdot 6$. Moreover, although there is a great deal of coal in the two counties, and mining can be profitably engaged in on the present, and even on a greater, scale for a good many years, the days of the field are numbered. According to the most trustworthy estimates, those of Dr. Hull, ${ }^{1}$ its available resources down to a depth of 4,000 feet are not onethird of those of South Wales; and at the present rate of consumption they will be exhausted in about a century.

2. Next may be taken the great continuous area which stretches from the West Riding of Yorkshire into Derbyshire, with a fringe of Nottinghamshire, and 
which is most conveniently spoken of as the Yorkshire Field. This has at present the largest output, 50,000,000 tons in 1901; and much the largest number of people employed, abont $183,000-23 \cdot 1$ per cent. of the whole: ' nearly one quarter of the total coal-mining population of the United Kingdom.' It is able to ship a certain quantity of coal for the Baltic from Hull; but the railway freight to the coast is a great disadvantage as compared with the Newcastle coal; and the demand is mainly furnished by the manufacturing needs of the great cities in its midst or on its borders-especially Leeds, Bradford, and the woollen and worsted towns of its northern end; Sheffield and the steel manufacture of its interior; and Nottingham and its hosiery on its southern edge. Barnsley is the chief mining business centre, and the seat of some of the largest colliery companies and of the miners' union. The available resources are very large, more than three times as great as those of the northern field; and the output is rapidly increasing; doubling itself between 1860 and 1880, and increasing 66 per cent. in the last twenty years. As the western edge is being worked out or becoming more expensive, mining operations are gradually being thrust further to the eastward into Nottinghamshire.

3. Next we come to what is in several respects the most interesting of all the fields, that of South Wales. Its output is, indeed, somewhat less than that of the northem field, and much less than that of the Yorkshire field-some 39,000,000 tons in 1901; and the number of people employed was in proportion, viz. 150,000 . But its production is increasing even more rapidly than that of Yorkshire: in the last

' Home Office, Mines and Quarries: Statistics (1901), pt. ii. 53. 
twenty years it has almost doubled. Moreover, the coal is on the whole considerably more valuable-its average price per ton in 1901 being about 11s. $8 d$. as compared with $9 s .4 d$. for Great Britain as a whole. ${ }^{1}$ To bring out the meaning of these figures something must be said of the quality of the coal. Coals are divided roughly into two great classes-bituminous and anthracite : terms which are seldom heard outside mining circles in England because our coal is, almost entirely, more or less bituminous, but household words in America, where over a great part of the country hard or anthracite coal is the only coal used in stoves and furnaces for domestic purposes. Coal is generally called anthracite when it contains some 90 per cent. or more of carbon; bituminous when it contains from 70 to 80 per cent. As a rule the coal of a district belongs clearly to one or other variety. But in South Wales there exist unusually large quantities of a coal of an intermediate sort, containing from 80 to 90 per cent. of carbon. This is the celebrated steam coal of South Wales. ${ }^{2}$ And there is a beautiful symmetry about the place of these different sorts of coal in the South Wales basin. The isolated portion to the extreme west contains hardly anything but pure anthracite. There is not very much of it anywhere in South Wales-about $2 \frac{1}{4}$ million tons a year, and half of this is exported. ${ }^{3}$ The extreme east is chiefly bituminous:

${ }^{1}$ Home Office Statistics, pt. iii. 173.

${ }^{2}$ Hull, Coal Resources, 9, note.

3 'Anthracite coal is to a considerable extent shipped from South Wales to continental countries for use in the stoves which take the place of the open fire in our own country, this form of fuel being found much more convenient for burning in inclosed stoves. The actual tonnage so disposed of is not easily ascertained, but it is probably one half of the whole. About twenty five years ago anthracite coal was largely consumed in the making of pig-iron, several important works, including those of 
between these two extremes, mixed with softer coal but preponderating more and more as one moves westward, is the intermediate or steam coal. Now this stean coal produces a greater heat at less expense for fuel and labour than any other, and it is especially desirable for the generating of steam. The better qualities of it are also practically smokeless, and accordingly it is the most desirable for the navy. South Wates, like the northern field, exports a very large proportion of its output; in 1901 almost half, $18,000,000$ out of $39,000,000$. But a lare part of this is of a kind such as other countries will not readily do without. There is, incleed, some steam coal in the north of England, but usually it is so mingled with other qualities that it does not pay to separate it unless price goes rery high. The United States also possesses excellent steam coal in West Virowinia, e.\% that of the Pocahontas mine; but hitherto the cost of freight to the coist and across the Atlantic has been a more than sufficient protection; and South Wales has enjoyed to some extent the advantages of a monopoly. But besikes the south-continental and naval demand, the coal is largely employed in the iron and steel works of the district, which have established themselves there (to some extent moved there from the Midlimds) because of the ease and cheapness with which the desirable sort of iron ore could be brought by water from Northern spain. The question whether. when iron ore and roal lie apart, the coal shall go to the ore or the

Ystalyfera and Amam, having used anthracite fuel exclusively. Nevertheless, anthracite continues to be uscd in increasing quantities for industrial purposes. It is also applied to hop and malt drying, distillery purposes, and in the munerons cases where the absence of smoke is impurtant. In the netropolis it is being much more largely used for raising stcam than it was.-The Iron and Coul Trades Review, January 23, $190 \%$. 
ore to the coal, is being more and more decided, in Europe and America alike, by the ore being carried to the coal.

It may be interesting to notice that the develonment of Cardiff and of its coal trade has been vastly facilitated by the construction of the great docks on the Bute property; and this explains the significance, in the industrial life of South Wales, of the chief agent for the Bute property, Sir William Thomas Lewis-the most strenuous upholder of the sliding scale.

Another point to observe is that the field is intersected by deep river valleys, which have facilitated the getting of the coal and also the construction of a row of roughly parallel railways to carly the coal to the coast. But the more useful a railway is for this purpose, the more disturbance to mining does its stoppage produce. Of these lines the most important is that which brings down to Cardiff the steam coal of the Merthyr Tydvil district; and it is therefore 110 mere accident, but highly significant, that the most epoch-making legal decision of modern times bearing upon the organisation of labour should have been arrived at in the case of the Taff Vale Railway.

4. Not far behind the three fields already described come the Scotch Coal Fields, if we make one single group of them. They lie so closely together that they form in some respects an economic whole; and the coalowners and the miners are each united in a single association. The output in 1901 was sone $32 \frac{3}{4}$ million tons, and the number employed about 101,000. But the several coal basins are separated from one another by other strata; and each field has its distinct peculiarities. Much the largest and most considerable is that of the Clyde Basin; which accounts for 
some $20 \frac{3}{4}$ out of the $32 \frac{3}{4}$ million tons, and for about 63,000 of the employed. This extends over several counties; but the greater part of it (some five-sixths) lies in Lanarkshire, which it almost entirely occupies. The other chief basins are those of Fife (output $5 \frac{1}{2}$ million tous; employed 16,000); Ayrshive (output 4 millions; employed 12,000); and the smaller field

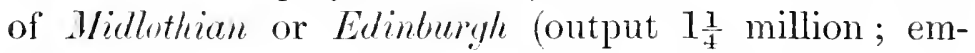
ployed 5,000). In their relation to the market the Scotch fields occupy a position intermediate between that of the Newcastle field and that of the Yorkshire field. They send away by water to competitive markets perhaps a fourth of their product: a much smaller proportion than the northern field, but far greater than the southern. But the different Scotch basins are not all exactly in the same position. Glasgow and Grangemouth export over a million tons each out of the twenty millions produced in the Clyde basin; but the chief demand for Clyde coal is furnished by the manufactures, and especially by the iron and shipbuilding industries, of the district. It is the presence of the clay-band and black-band seams in the coal measures of the neighbourhool of Glasgowfurnishing the ironmasters with the ore and flux as well as the coal they require-that has made Glasgow one of the great centres of the iron and steel interests. But from Kirkcaldy about $2 \frac{1}{4}$ millions are exported, i.e. half the output of the Fife basin: so that the Fife shipping trade is relatively of much more importance. Fife, indeed, competes with Northumberland very closely in the Baltic market. Owing to the quality of the coal, Fifeshire prices have to follow those of Northumberland at the distance of about a shilling; and Northumbrian conditions, including the remunera- 
tion of labour there, are watched very keenly by both masters and men.

Let us add that the output of the Scotch coal fields is steadily growing, as well as the number of men employed, though neither so rapidly as in the Yorkshire or South Wales fields; and that their estimated resources for the future are about half those of each of the fields just mentioned, and not very far from twice as large as those of the Newcastle field.

5. Only one other field remains which can be put in the same class as the four already described-that of Lancashire and Cheshire. Its output in 1901 was $24 \frac{1}{4}$ million tons, and the number employed was about 92,800. The production, with occasional setbacks, is slowly increasing; but the relative importance of the field is apparently diminishing. Under two million tons are exported or shipped coastwise; and the chief demand is for household and manufacturing purposes in the neighbourhood itself. In this respect the field is like that of Yorkshire.

The smaller fields call only for passing mention. Taking them from north to south, there is the Cumberland or Whitehaven Field, which supplies the blast furnaces of Workington; the North Wales Fields in Denbighshire and Flint; the North Staffordshire Field, which supplies the Potteries; the South Staffordslive Field, which supplies the Black Country ; the Coallrookdale Field, which witnessed the introduction of the modern method of smelting iron ore by coal instead of charcoal, and has paid the penalty by its early exhaustion; the coal tracts in Leicestershire, and in Warwickshire about Numeaton; that of the Forest of Dean; and that just outside Bristol. Most of these are not only small but stationary, or even retrogressive, in 
their productivity. The two largest and most interesting are those of North and South, Stafiondshire. In the latter it was the proximity of iron ore and of coal to one another which furnished the foundation for the prosperity of the English iron industry during what may be alled the Wolverhampton period of our commercial history - the sixties and early seventies of last century, before the rise of Mildlesborough and Cardifl. The output of the two fields together amounts to some 14 million tons; and they give employment to 52,500 persons. I am compelled to pass orer the other fields without further characterisation. But the fields of Newcastle, Yorkshire, South Wales, Scotland, Lancashire, and Staflordshire between them produce 94-humdredths of the total ontput, and cecupy a similarly large proportion of the total number of British miners; so that we may safely leave the rest out of our general survey.

Proceeding next to consider the orwanisation of labour in these several districts, we have first to observe that it is now practically all-embracing. An overwhelmingly large majority of all the miners of freat Britain now belong to a trade mion. This has long been the case in Northumberland and Durham; lont it has been by no means miversally so until a quite recent period. As late as 189.j a careful foreign observer could speak of South Wales as a district 'al solutely morganised:' this in his opinion was the only rearen why the sliding scale survived there, after it had passed away in all districts where

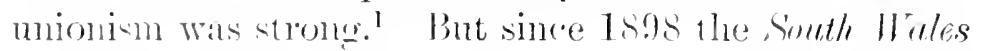

'. M. Wilhchn, in de Rousiers' Le Trade.Unionisme en Angleterre, 209. 
Miner's' Federation has gathered all the local societies under its wing; and the number of subscribing members in the district has almost doubled-yoing from about 72,000 to 124,000 . And, as this example indicates, the movement of the last few years has not only been towards the intensification of mionism among the mining population, but to its consolidation, by the grouping of more and more local societies into great district federations, like the Lancastive and Cheshire Niners' Federation, formed in 1897, or the Scottish, IFiners' Federation, formed in 1894. ${ }^{1}$

The last-mentioned instance furnishes an excellent illustration of the extent to which considerations of business and administrative convenience are favouring the association of men into large bodies under the more or less effective control of small representative councils with which the masters may readily negotiate. In the report of the conferences between the Coalowners of Scotland and the Scottish Miners' Federation, which led to the formation of the Scotch Conciliation Board, in 1899, it is interesting to observe the anxiety of the coalowners that 'the whole country shall be got into line.' ${ }^{2}$ At the next meeting the chief representative

1 This consolidation is due in part to the policy of the Miners' Federation of Great Britain, which refused to admit the Lanarkshire miners by themselves, and urged the federation of all Scottish miners. The Federation of Great Britain still includes a certain number of separate county associations, received at an earlier date; lout, whenever it has had an opportunity of late, it has insisted on federation mto great provincial groups as a prerequisite of admission to the British Federation.

2 'The Champan . . . One thing that this committee' (of coalowners) 'would like in the formation of such a board is, if possible, that we should try" to have all the districts of the comtry represented. Some of our members feel that, unless their districts are to be represented, then there is great"difficulty in their joining a board to act for the whole comntry, so that we would throw out the suggestion that between this time and our meeting, a month hence, you should try to get the whole country into 
of the men amnounced, to the satisfaction of the employers, that 'the Stirlingshire miners have now formed themselves into an organisation and have made application to the Federation - dissolving the previous independent union; and he took credit to himself for having thus carried out his 'pledge' to 'extend the influence' of the Federation. On the other side, the employer's also in each district are now sufficiently well organised to allow of negotiation in a representative capacity. "In some cases the association came into existence at first for other purposes, e.y. in Northumberland for the regulation of prices; ${ }^{2}$ but the common pressure of labour difficulties has made combination necessary everywhere: and thus organisation on each side, at various dates and in varying degree, has stimulated, by opposition, or actually by encouragement, completer organisation on the other.

We may observe also that, with the completion of

line, if possible.'-Proceedings at Conferencc, March, June, July, 1899, 102. $C f$. the subsequent discussion, 106 seq.

' It is more difficult to obtain information about employers' unions than about workmen's unions, since the former do not make any returns of membership, funds, expenditure, ic., to the Board of Trade. But a list of coalowners' associations, with their secretaries, will be found in the Directory of Industrial Associations, published by the Board of Trade in 1902 ; and the rules of the associations of coalowners (Northumberland, Durham, South Wales and Monmonthshire, Lanarkshire, Cannock Chase, North Wales, West Cumberland, and some others), which were com. municated to the Royal Labour Commission, are abstracted in its volume Rules of Associations of Employers and Eimployed (1892), 103-109. It is said that some of the associations (probably the smaller ones) attempt in some degree to regulate the price of conl, by issuing winter and summer price lists; that some of the coalowners of the several districts refuso to join in this action and consequently abstain from joining the local associations. But, however incomplete the membership of the associations may be, it is ovident that the arrangements they make in the matter of wages are accepted by the great body of coalowners.

"Interview with Mr. R. O. Lamb, in Conciliation in Trade Disputcs (Nrweastle Leader Extra) 1894. 
the miner's' organisation, the old refusal to grant what is known as 'recognition' has altogether passed away. This has been already implied, but it is worth dwelling upon for a moment. The difficulty about recognition was one of the sorest points in the early history of unionism; it is still a source of trouble in some of the small trades in England; while in America it bulks very largely in almost all industrial disputes. But in the older coal fields of England the unions have been recognised (i.e. formally treated with as representing the men) for more than a generation-in Northumberland for instance since 1871 ; and, even in those districts in which unionism has been slow in developing, the stage of recognition has been reached for some years past. What was meant by refusal to recognise may be illustrated by the correspondence which passed between the secretary of the County Board of Lanarkshire Miners and the secretary of the Lanarkshire Coalmasters' Association as late as 1887. The men's secretary had written on behalf of his Board to request an advance in miners' wages; to which he received the following reply, which I quote in extenso, as a 'select document' in industrial history: "Dear' Sir,-I have now had an opportunity of laying your letters before the Executive Committee of this Association, and, out of courtesy to you, I am instructed to reply that all questions of wages will be settled between the coalmasters and their workmen direct, in accordance with the rules of this Association. Yours truly, __ Secretary.' ' And in 1893, while the English coalowners of the Midlands, during the great strike, were gravely and politely negotiating with

${ }^{1}$ Royal Commission on Labour. Evidence, Group A, ii. 74. 
the representatives of the English Federation, the Scotch coalowners refused to meet the representatives of the similar Scotele body. But now, as I have before said, the two parties in Scotland are regularly represented on the Board of Conciliation, and all the office work which it requires is anicably managed by the very writer of the letter just quoted in conjunction with the men's secretary.

What I want to emphasise is that for the earlier reluctance to recognise the union there was usually a sound commercial reason. Of course there was a good deal of crude human nature in it; such as personal dislike of the labour 'agitator.' There was, and is in Anerica, the weighty consideration that to recognise a mion is to strengthen it: to be treated as representing the men enables the union to tighten its hold upon them and to draw in the hesitating. But, besides this, we must allow for the fact that mutil a muion is so strong that it really represents the sreat mass of the men engaged, and so well disciplined that the men will follow their leaders, it may be waste of tine to negotiate with the union's officials. 'To the employers it is a matter of indiflerence how the representatives of the men manage to "arry ont their anleenents-whether they are given 'plenary power' to negotiate on belualf of the mincrs, or whether they have to obtain the subsequent acquiescenco of their constituents by aroment and the weight of their influence. The employers at a Conciliation Board are not pinnaly philanthropists or statesmen: they are primarily the purchasers of a (rommodity, labour; and what they want to be assured of is that the other party can 'make telively of the soods. And thus a complote and well-tisciplined

' P' de Rousiers, The Lubour Question in Britain (1836). 228. 
union does not need to beg for" 'recognition;' it will be recognised like any other business fart.

This is the primary consideration. But it is evident that the representatives of the men will secure more respect from the employers' representatives if they have a thorough acquaintance with the letails of the work to be discussed. And here a contrast at once presents itself between unskilled and skilled labour. Unskilled labour is commonly easy enough for anyone to understand; while the workers in unskilled crafts can seldom produce from among their midst men of sufficient education to do the secretarial work of the societies, let alone present their case clearly to the employers. Naturally enough the labour leader in this case seems to the employer a mischievous outsider. But in the great skilled industries, like the textile trades or the coal trade, there is so much technical detail involved in the negotiations, that only men thoroughly trained in the occupation itself can undertake the adrocacy of the workman's cause. It has been often pointed out that legislation itself has helped to produce this class of technically competent labour representatives in the mining industry. The hewer's of coal are paid by weight. Hitherto it has been impossible to devise automatic weighing machines which will meet all the requirements of the situation. And everywhere, in America as in England, trouble has arisen from the suspicion of the men-whether well or ill founded matters not-that the employers' weiglımen might act unfairly. The demand of the men that they should be allowed at their own cost to provide a cherli weigluman was granted by the Mines Regulation Act of 1860 . By the amended Act of $18 S 7$ it has actually been provided that a bare majority, ascertained by ballot, of the 
miners in any particular pit can decide to appoint a checkweigher, and that then his wages shall be paid by a compulsory deduction from the wages of all the men employed at that pit. As a result a whole class of cherkweighers has come into existence. But such men must have had experience in work at the face of the coal, or they would not know theil business. They must be trusted by the men. or the check would be valueless; they must possess some intelligence and readiness with figures, or they could not keep the accomnt. Nen like these are naturally marked out to be the officials of unions; and, as a matter of fact, a large number of the officials, from the secretaries of single pit branches to the secretaries and presidents of the oreat feclerations, are or have been checkweighers. Such men may not possess any knowledge of the commerial side or of the engineering side of the mining business; but they have a thorough knowledge of the processes and conditions of lolump : and this constitutes, so far as it goes, a solic ground for the coatmaster's respect. ${ }^{1}$

Having said so much with regard to the oroanisation of mining labour in general, I propose to call your attention in particular to the merohaniom for the determination of wases. This is now miversally effected, with the exreption of only one district, by means of Boards of Conciliation, equally representing the two parties. The one exception is south Wales, where, up

'It is one of the merits of Mr. and Mrs. Webb's books to have called attention to the growth of the class of technical expert ofticial in unionism. On the eheckweigher in particular, sce their History of Trade Unionism, 28:7 ser., and Industrial Democrary, 16, 44. F'or the biography of the President of the Cammock Chase Miners' Association, de Rousicrs. Trute-Unionisute, 201 . 
to the present, wages have for many years been determined by a sliding scale. Whatever may be the result of the negotiations now going on, we may be quite sure that a Board of Conciliation will soon be established in South Wales; ${ }^{1}$ and then that method-though with important differences, to which I shall recur, between the several districts-will be absolutely miversal in Great Britain. A brief outline of unionist history will bring out more clearly the significance of the statement.

Let us begin with the miners' unions of Northumberland and Durham. There was first a period of complete want of organisation down to about 1842. Then came thirty years in which the mions gradually grew stronger, and a long series of strikes, especially prevalent in the sixties. Then, with the prosperous trade of the early seventies, came the recognition of the unions for the sake of convenience, and the fixing of wages by joint agreement. Then, as depression set in, wages became more difficult to adjust, and the men agreed to arbitration. This was the period when arbitration won its first great successes, and Sir Rupert Kettle gained his high and well-deserved reputation. $\mathrm{Bu}^{+}$, as both parties accepted the principle that wages should be determined by prices, the practical result of these arbitration proceedings in both counties was to work out the relation which, it was held, ought to exist between wages and prices-starting with a certain year as basis, when the relation was assumed to have been acceptable to both parties. These relations needed only to be written down to form a sliding scale; and so it was that the series of arbitrations led to the adoption of a sliding scale in Durham in 1877 and in Northumber-

1 This has since been the case. For the rules of the new South Wales Board of Conciliation, see Appendix II. 5. 
land in 1878. In sonth Wales it har been introduced in 1875. It might appear that the evolution had reached its highest point and no further progress was possible. The words of Professor Mumro in 185.j are well known: 'It seems to me that the principle of the sliding scale is the greatest discovery in the distribution of wealth since Ricardois enunciation of the law of rent. That it has a creat future before it, not only in the iron and coal tracles but in other industries, I have no doubt.' Professor Mnnro was doubtless paying, as he thought, the highest possible compliment to the shiling scale; even though a critic might observe that the two discoveries of the law of rent and of the sliding scale are discoveries in altogether different senses. A young Oxford economist was more cautious-Irregular Neg(otiation, the Board of Arbitration, and the Sliding Scale were, according to him, only 'stages in the theoretical order of development.' ' But most people would probably form the impression that the theoretical was also the desirable and the final. As is well known, the sliding scale hals, until very recently, been tenaciously adhered to by the coalowner's of South Wales; and it was forced back upon their men in 1898 after a desperate strike on their part against it. Yet as a formal institution it was being abandoned in the North of England at the very time when eromomist s were awakening to its merits.

In Northumberlund a scale was agreed upon in 1879. It governed wages until 185\%, when the men gave notice to determine it, in order to have it revised in their farour. This amendment was anicably agreed

'Sliding Scales in the Irem Industry (Nanchester Statistica Society, 1886). 26.

2 I'riec, Industrial Perece 1887', 7-8. 
to in 1883; and the revised scale continued in force till 1886. But the devisers of the scale had not contemplated a period of steadily falling prices; and prices dropped so low that the sliding scate no longer-in the language of Mr. Ralph Young, the well-known miners' secretary - gave the employers the relief that was required.' ' The enployers now in their turn gave notice, and asked for a reduction in the basis. The men struck, in spite of the remonstrances of their leaders, and were badly beaten. The employers secured the reduction they asked for: but by this time both parties were heartily sick of the words 'sliding scale,' and no new one was drawn up. For the next few years general changes were mutually agreed upon from time to time at conferences between committees of the two parties.

In Durham a scale had been indopted in 187t. In 1879 the coalowner's demanded a revision of the scale, and carried it throngh after a six weeks' strike. In 1882 and 1884 it was readjusted - the last time so effectually that it stood the hard times that followed for three years after the neighbouring comty scale har? succumbel. But, suitable as it was for bal times, it was not equally well adapted to the good times that now began. In 1889 the men gave notice to determine it; and, from that time on, wages, as in Northumberland, were settled by conferences without recourse to an accepted scale.

With the abandonment of the sliding scale ended what may be conveniently spoken of as 'the Newcastle Period' in the mining labour movement. During this

1 Interview in Conciliation and Trade Disputes, 2. The four interviews, in this 'Newcastle Leader' Extra, with Messrs. Young, Lamb, Patterson and Simpson, give, from the two sides, the best brief narra. tives with which I am aequainted of events down to 1894 . 
period the example of the northern miners, and especially their acceptance of the sliding scale, was very influential; and of the several transitory attempts to bind together all the miners of the country in one national association, that of the Miner's' National Union, which was dominated by the two northern counties, under the leadership of Mr. Thomas Burt, was the most successful. During the sliding scale period it included Torthumberland, Durham, and Yorkshire. But in the late eighties opposition began to show itself among the Yorkshire miners, led by Mr. Benjamin Pickard. The Forkshiremen advocated a more bellicose policy than the northem leaders favoured, and in particular they put forward the principle of a minimum (or, as it was called in more picturesque, if less precise, popular language, a living) waye. They thundered against the principle that wages should follow prices: let prices, they demanded, follow wages; at any rate, let prices be so fixed as to include a liring or minimum wage; let such a wage be a first charge on coal mining. The northern men were not disposed to adopt the new policy; and there were other causes of dissension between them. Arcordingly, in 18ss-9 the Yorkshire niners seceded, and fomded the Miners' Federation of Ereat Britain, in avowed rivalry to the National Union, which, being now reduced to Northmmberland and Thrham only, soon went out of existence. And so becan what we may all "the Yorkshire or Midland Period, the period in which the example and policy of the Yorkshire Federation and of the Federation of Great Britain, of which it is the leading member, have becu the most powerful influences in determining the direction of unionist aetivity.'

1 The accounts most free from lias of these transactions will be found 
In 1893, the year of the great Midland strike, the Federation included all the men of the Midlands, of Yorkshire, and of Lancashire - a third of all the miners of the country. Into the merits of that strike, one of the most important episodes in recent industrial history of this country, I camnot now enter. Many members of my audience remember it very well; and I need only remind you that the Federation struck against a large reduction demanded by the coalowners, and that after a suspension of work for sixteen weeks the Government intervened to bring the parties together and arrange an armistice until a Conciliation Board should be established. But it may be asked why the Yorkshire and Midland miners were ready to strike at a time when the coal market was certainly not buoyant, while the northern miner's refused. The explanation has already been given in our comparison of the markets of the northern and of the midland fields. The midland market is mainly an inland and home market, and the demand, to a considerable extent, has to wait and go on piling itself up until it can be satisfied; while half the northern coal goes to foreign markets, which could readily be supplied from other sources. And as a matter of fact the midland coalowners were able to clear off their stocks during the strike, and, when it ended, to go on paying, first the old wages, and then, under the decision of the new board, the former wages only slightly reduced.

But it is the establishment of the Board itself in 1894-which was spoken of at the time as almost a counsel of despair-which has been the most fruitful in consequences. In the first place, it has lasted, with

in M. Wilhelm's chapter in de Rousier's' Trade-Unionisme, 219, and in the Circulaires of the Paris Musée Social, A. 3, 6 (1896), 16 (1897). 
renewals from time to time, up to the present, and it has been agreed to by both parties till January 1904. Ten years is not a despicable term of life, and during that time it has prevented all gemeral strikes in what are called 'the Federated Distriots.' In the second place, the example has been followed by the establishment of similar boards everywhere else. In Northnmberland a Conciliation Board was established in 1S94, terminated in 1896, and re-established in 1900, and is still in existence; in Durham a board was created in 189\%, terminated in 1896 , and re-established at the end of 1599 ; in Scotland a Conciliation Board was similarly established in 18.99; in South Wales, as I have said, one is now in process of formation. In the third place, the rules for the Board of the Federated Districts, while stating that its function is "to determine the rate of wages" for a given period, say nothing whaterer of the principle to be followed in deteminim the rate. It leaves it open to the board to make wages follow prices, or to take any other considerations or' 'factors' (as they are called) into account. And the same is true, with limitations in two cases more apparent than real, of all the other Conciliation Boards so far established. But, finally, the Federated Districts Board is limited in its work by both a minimum and a maximum. The text of the agreement runs: 'to determine the rate of wages within the following limits-namely, that during such period the rate of wages shall not be below 30 per cent. above the rate of wages of $18 \delta S$, nor mole than fol per cent. alove the rate of wages of 1bss.' 'This is a very awkward way of stating the thing. It would be murh simpler to take a fresh starting-point; but the old phraseology is 
long-lived, and the minimum is likely to be described for indefinite years to come as so much per cent. above the rate or standard of $188 \mathrm{~s}$. Now such a compact may be fairly described by the coalowners as a matter of temporary expediency, and they may be so confident that during the short term of the agreement prices will not fall very low that they may think the promised minimum of no practical importance. But the miners have naturally regarded the compact as an acceptance of their principle of a minimum or living wage. And so it has been generally interpreted by the miners elsewhere. True to their old convictions, the Northumberland and Durham men have attached no such minimum proviso to their Board. But the Scotch miners, on the constitution of their Board in 1899, secured a minimum of $31 \frac{1}{4}$ per cent. over the 1888 basis, though in the first instance only for a year. One of the chief coalowners present at the conference justly remarked that the leader of the men had 'clone a good deal when he had got a large body of men, both at this end of the table and at his own, to come to one mind on this principle' of 'a minimum wage.' ${ }^{1}$ And, finally, in the draft agreement which the South Wales coalowners themselves presented to the men for acceptance last December, a minimum has appeared: "during the continuance of this agreement the rate of wages shall not be less than $16 \frac{1}{2}$ per cent. above, nor more than $57 \frac{1}{2}$ per cent. above, the December 1879 standard of wages paid at the respective collieries.' The men, in order to put them-

${ }^{1}$ Procedings at Conference, 158. The speakel added, as to the principle, that the coalowners held it to be "quite within the region of experiment only.' But it has reappeared on the renewed agreement of 1902, and is now $37 \frac{1}{2}$ per cent. above basis. 
selves in line with the Ferlerated Districts, now that the South Wales Federation has joined the Miners' Federation of Great Britain, are sticking out for a ninimum of 30 per cent., which they will probably get; but over the question of principle there is no longer any dispute in the Welsh roal field. 


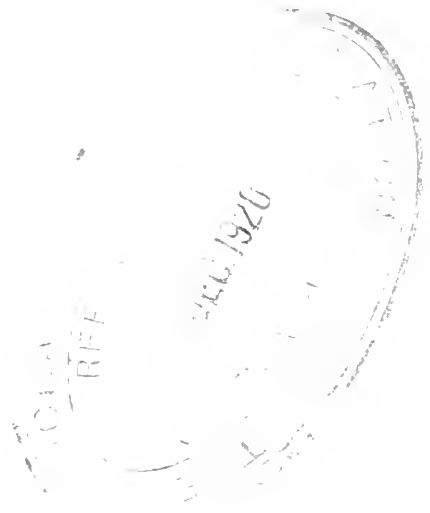

-

$-$ 


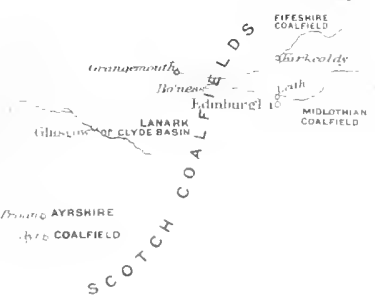

TH E

COALFIELDS GREAT BRI'TAIN.

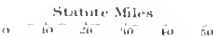

1tatem
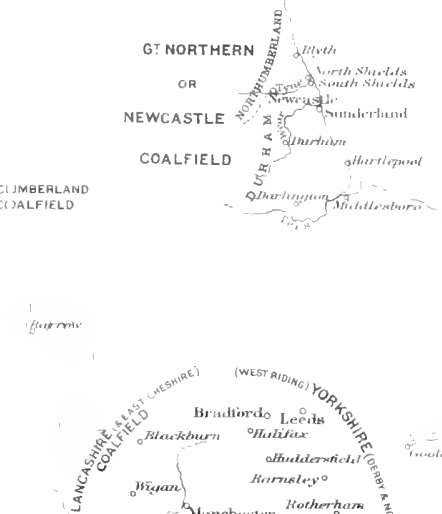

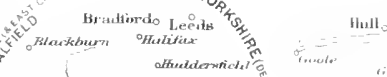
sita

Anomeley 0 shatieldo

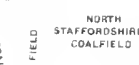
Ghesterfiedt

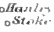
Nortuaghimo $\frac{7}{m}$

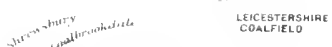

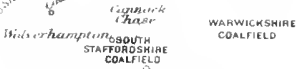

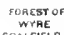

COALIELLO
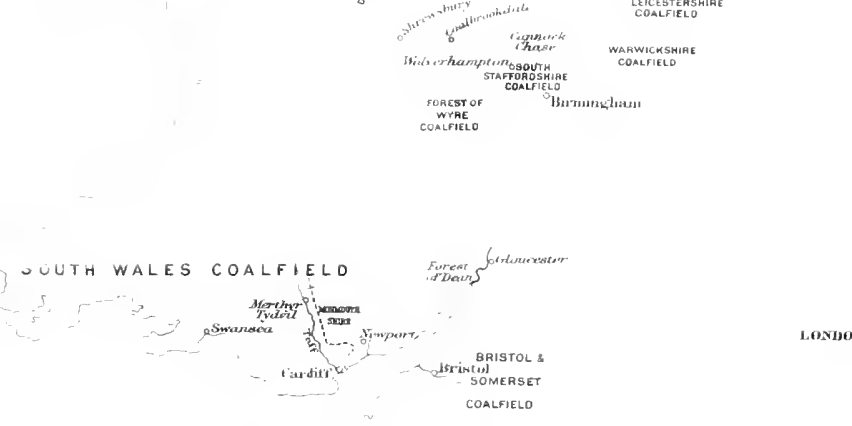


\section{LECTURE III}

\section{PRICES AND WAGES}

The principle of a minimum wage, recognised, in the sense explained, in the agreement in the Federated Districts in 1894, has not yet been subjected to any severe practical test. For some years after that date the price of coal did not vary very much ; from 1898 to the middle of 1900 it went up to a great height and wages went up with it. For the last two years prices have been dechining from the point then reached; and considerable reductions have everywhere been effected in wages by the mechanism of the Conciliation Boards. In the Federated Districts last June Lord James, acting as chairman of the board with a casting vote, gave a reduction of 10 per cent. from the previous 60 per cent. above standard; and he is at present engaged once more in considering the rate. But wages still stand at 50 per cent. above standard; and there is a pretty wide margin between that and the 30 per cent. of the accepted minimum. There has not yet been sufficient depression to bring the actual wages dangerously near the minimum; and it will be then that the strain will come.

When, however, the strain does come, it is by no means improbable that it will still be found possible to maintain the minimum in the Federated Districts of England and Wales. Let us be clear what the minimum involves. It does not involve any right to 
employment. It does not compel any coalowner to keep his mine open ; it only compels him, if he wants to work his coal, to pay so much a day for working it. The minimum is the wage which an average miner is able to earn with an ordinary day's labour at the piece rates established for that particular mine or seam. The rule, therefore, does not even compel a coalowner to give the usual maximum of five days' work a week. The individual coalowner-and coalowners generallymay think it wiser, when prices go down and wages are irreducible, to work only two or three days a week, and by diminishing the output, check the further fall in price. And, so far as the miners are concened, their leaders are ready to avow the opinion that if the maintenance of the minimum means weekly earnings too small for subsistence, or incleed no earnings at all, even such a consummation were better endured than the sacrifice of the daily minimum. Better, they would say, that savings in the Friendly Societies should all be swallowed up; better even that people should starve and a whole popnlation slowly abandon an occupation, than that the occupation should be carried on on terms dangerous, in their judgment, to the permanent well-being of the workers. A minimum tomage rate, working out into a minimum day wage, would not, therefore, necessarily mean ' a living wase' for the year or even for the week, in spite of the reneral confusion of thought on this subject during the great strike of 1593. On the other hand, experience has abundantly iroved, though apparently the contrary is often assumed, that the acceptance of extremely low piece wages is also no guarantee that a total wage can be secured on which the workmen ran wholesomely live. And miners have the same reasons, whether bad or 
good, as the lawyers for believing that the policy of 'minimum or no service at all' is, on the whole, the more advantageous one.

Certainly it is not clear that in the Federated Districts, including therein South Wales and Scotland, the minimum wage will meet with insuperable obstacles. Although the demand for coal fluctuates somewhat with the price, and fluctuates also, so far as manufactures are concerned, with the state of trade, and, so far as household uses are concerned, with the severity of the winters, it is to a considerable extent a necessity of modern life, a necessity the price of which may rise very considerably without proportionately checking demand. So long as the minimum is anything like what has actually been proposed, and the price does not rise very high, I see no reason why the additional cost of labour involved in the minimum should not be thrown on the consumer. The effect this might have on English trade generally is a complicated question, and I know of no very convincing attempt to answer it; but miners are no more likely to pause to consider such problems than the coalowners themselves. And it is notorious that the coalowners have not refrained from demanding the highest price that circumstances could give them, even when the high cost of fuel was evidently endangering the iron and steel manufactures of the "ountry.'

1 The only attempt, so far as I know, on the part of any economist of reputation to deal systematically with the problem of the possible effect of a minimum wage upon English trade in general is to be found in Professor Smart's Stulies in Economics (1895), 42-46. Mr. Smart concludes thus: 'This is the argument most often used against any organisation which aims at keeping up mining wages. Englind must have cheap coal if she is to remain what she is. Wage is the largest element in the cost of production of eal; consequently there must be no artificial barrier in the way of making miners' wages as low as necessary to 


\section{I am dealing now only with the Midland districts and Lanarkshire, which supply in the main a home}

compete with the world which bnys our coal and our manufactures.' He justly comments: 'It is not a pleasant argument. It sounds to me as if we proposed doing with the miners what a general is sometimes foreed to do with a regiment-when it is absolntely necessary to gain time, and he orders it ont to hold a position where he knows it will be cut to pieces. But if we admit the premiss, "England must have cheap coal," we must face the conclusion fairly and squarely, and not shut om cyes to it.' One would think that if the conclusion is so mpleasant, it night be worth while to examine more elosely the premiss.

With curvent forecasts of the effect of a minimum wage on English industry may be profitably compared the following comments of the Economist in its Review of 1900 (Smplement to its issne for February 16, 1901) on the high prices secured by the coalowners in that year: "There is not an industry in the country that has not suffered from the enhancement of the cost of production consequent upon this dearness of coal. And while coalownors and miners, being hmman, have taken the fullest advantage of their olportunity, it is not surprising that their undisguised determination to screw the utmost farthing out of consumers without regard to ulterior consequences, should have caused the question to be raised and disenssed, perhaps more eagerly than ever before. whether it is right or expedicnt that this limited class shonld be permitted such a perfectly free hand in exploiting, for their own benefit and to the detriment of all the rest of the community, the coal resources of the country, which constitute a great national asset. To our iron and steel industries the high price of coal has been specially hurtful. In the cognate industries of the United States there was, towards the end of Mareh last, a great breakdown. Prices, which during the previous boom period had becn pushed up . . rapidly collapsed. and it became apparent that production... had outrun demand. As a measure of relief, the American manufacturers songht strennously to enlarge the existing, and to open up new. foreign markets for their products, and to achieve that end were prepared to make heary cuts in prices. To our mannfacturers this competition would have been serious in any ease, but it certainly wonld not have prevailed against then to anything like the extent it did had it not been that, in contending against it, they were handieapped by the high price of coal, which constitutes so large an item in the cost of production. As it was, the Americans were able not only to ent us ont to some extent in forcign markets, but also to wrest from our manufacturers some of our riwn lome trade.'

It is not likely, in our existing industrial system, that either coalowners or coalminers will be influeneed by considerations ontside their own inmediate interest. They incritably pursue the same policy as all others engaged in lmsiness; and the noral condemnation sometimes expressed by men of other trades is meonseiously hypocritical. 
market, and with South Wales, which supplies foreign markets which would be compelled to pay quite high prices for steam coal because they cannot get it so good and so cheap elsewhere. ' The limits to this endurance are such prices as would induce a supply from other directions. I suppose a very high price maintained for some months might even attract to England coal from Germany and France. More pressing is the danger that the Mediterranean trade of South Wales would be captured by American collieries. Some American coal was actually shipped to France during the high prices of 1901. American coal is more cheaply mined than English; and American enterprise may substantially reduce freights. Nevertheless, between the cost of delivering South Wales coal and American coal in French and Mediterranean ports there is still, and is long likely to be, a margin sufficiently large to permit of the maintenance of wages at a reasonable minimum. ${ }^{2}$

And, as already remarked, the premiss that 'England must have cheap coal' is by no means free from doubt. The argument that England needed cheap labour to maintain its foreign trade was invoked with equal sincerity against our Factory legislation. Evidently it is a question both of degree: 'How cheap must be the coal or the labour?' and of other' and possibly counterbalaneing considerations.

1 The position of the Midlands as doing 'a land sale business' and being therefore better able to keep up prices, is a commonplace with the coalowners of other districts. For an example from Scotland, see Proceed. ings at Conference, March-July, 1899, 37. And in the discussions on the coal tax the representatives of other districts commonly spoke of Wales as having a quasi-monopoly; e.g. Sir Edward Grey, as reported in The Times for June 12, 1902. Half the Scotch export, as we have seen, is from Fife; see above, p. 28. For an outside opinion, see de Rousiers, Labour Question, 208: 'It would, therefore, be bad policy for the Durham and Northumberland miners to create a coal famine in their (foreign) markets, although such a course might be advantageons to the interests of the Midlands.'

2 Freights vary every month. In October 1900 when the high prices of English coal turned American attention to the subject, the American 
Whatever may be the effect, moreover, of fluctuations in demand, I suppose there can be no doubt that coal prices fall more rapidly in times of depression and far lower than they otherwise would, owing to underbidding-the anxiety of coalowners and their selling agents to clear off their stocks at almost any price. When they offer to sell at reduced prices-especially when they make long contracts-they hope to reduce their labour cost. There is some force in the argument that the mere knowledge that labour cost camot be reduced beyond a certain point would itself have a certain steadying effect upon price, and so enable a better wage to be paid. ${ }^{1}$

Competition among coalowners may, however, be limited by combination among themselves as well as by irreducible costs. It is true that combination has not hitherto been particularly successful, especially in times of depression. In South Wales, for instance, attempts at combination have repeatedly failed: but (not to speak of the Newcastle Limitation of the Vend, which survived till 1844ㄱ), there was a local Sales Association in Durham in $189 j$ which had a consideral,le effect upon prices for a time; ${ }^{3}$

Consul-General at Bareclona reported to his Govermment (U.S. Consular Reports, No. 821) that the freight on conl cargoes to that port was 11s. 6d. per ton from Cardiff, and 12.6. 6d. from Neweastle and Glasgow, while from America it ranged from 20s. to $22 s$, thongh in May one cargo had been imported at a cost of 188 . a ton.

${ }^{1}$ This is the nsual contention of the miners. Thus Mr. Weir argued at the Seotch Conference in 1899 (Proceedings, 12:3): 'If yon'-the coalowners - 'would compete less anong yourselves you would have less to do with competing with others ontside, and if we had the ninimum wage fixed at $6 s$. it wonld help to stop the competition anong yourselves, because you would have that charge to face.'

Its history is given in an article by Professor Cohn of Göttingen, in the Economic . Fournel, v. 5.50.

: It was estimated that there were twenty-six million tons in the 
there is to-day, and has for some time been, a similar association which regulates prices in Fifeshire; and even the agreed price of the Coal Exchange does something to check excessive underselling among the merchants in the London market. But the air is now more fully charged with the spirit of combination than at any time during the last fifty years; and we may anticipate renewed attempts at combination or amalgamation in colliery business on a large scale. And it is significant that one of the main purposes of the proposed Coal Trust of the late Sir George Elliott was to provide the miner with a suitable minimum wage: it is noticeable also that one of the heartiest advocates of the cause of the miner's in South Wales, Mr. D. A. Thomas, M.P. for Merthyr, and himself a great coal merchant, is also the author of a plan much discussed some few years ago for a combination of all the steam-coalowner's of England to prevent underselling. Now that the men are everywhere well organised, and that the coalowners are accustomed to work with them on Conciliation Boards, we may expect that any such combination will be supported by an alliance with the unions-probably taking the form, on the part of the unions, of an agreement to withdraw labour from a coalowner selling beneath the price agreed upon. The men woukl be quite ready for such an alliance. It was the representative of the men in the Scotch negotiations of 1899 who called the attention of the coalmasters to the success of the Westphalian Coal 'Kartell.' I will quote his words: 'I dare say most of you have read the last report of the coal trade in Westphalia in Germany.

association, and seven millions outside it in that county.-Proceellings of the Durham Board, April and May, 1895, 97. 
That is very interesting indeed, because it repeats the history of our coal trade here. For many years . . . local competition had brought down the price to a point at which the employers could not make profits and pay fair wayes. The employers, under joint cooperation, agreed to prevent competition in future, and the consequence has been that wages have gradually risen there-risen by almost one-third-and profits have kept steady. . . The men can get steady employment all the year round. It is better for the general trade and better for the workmen.' ' In 1901 the same speaker declared to the coalowner's, "If it comes about that prices fall beyond a certain point, then we will gladly join in any well-devised scheme to keep the prices at a point which will enable you to pay us $S s$, per day and get a fair return on your invested capital." :

But in what I have been saying hitherto of the practicability of a mimimum wage, I have expressly linited myself to those districts which are either free from foreign competition or enjoy a limited monopoly in foreign markets. The difficulties would be more considerable in the case of Durham; and still more serious in the ase of Northmberland. The same is true, however, of Fife, where the minimum principle has been recognived for some years; thongh it has not yet been severely tried. Fife and Northmmberland compete against one another in the Baltic market; and an agreement between them to divide the market, withont rompeting in price, is rertainly not impossible. But both Torthumberland and Fife are exposed to Westphalian competition. The eflorts of the Westphalian unions may be expected to bring Geman wages nearer 
to English; and the 'solidarity' of mining labour-which the English leaders do all in their power to promote by means of International Congresses-may go so far that no nation will spoil the miner's cause in another country by invading his home market. But it is the German home market which we are already supplying; and we camnot suppose that Westphalian miners would back up a Northumbrian demand for a minimum by refusing to supply the furnaces of their own country. To the outside observer it certainly looks as if the Northumbrian miners had good reasons for hesitating to admit the minimum into their working programme.

With the exception of Northumberland and Durham, the operations of all the Conciliation Boards are at present limited to the range of rates between a minimum and a maximum. It will be observed that the men make no difficulties about the acceptance of a maximum. To them it is far more important that wages should never fall below a certain point than that they should sometimes rise extremely high. They are ready to barter the one advantage for the other; and they argue, with some reason, that if the employers are sometimes given by the maximum limit cheaper labour than they might otherwise secure, they ought to be able to sometimes pay more than the immediately existing state of trade would warrant. ${ }^{1}$ The force of this contention will depend on the comparative likelihood of the two situations. It must be noted that the maximum

1 Thus Mr. Smillie, the chief miners' representative, at the Scotch Conferences of 1899 frankly confessed: 'My own opinion is that the minimum wage may be rather against the employers when things are very dull, but the probability is that if trade keeps good for eighteen months or two years the maximum will wo.k out very much in favour of the employer.' His anticipation would scem to have been to some extent fulfilled. 
of 60 above standard in one case, and 100 above in the other, was actually reached in the Federated Districts and in Scotland in 1900-1, when a mere sliding scale would have given higher wages; ${ }^{1}$ so that hitherto the pliability of the nuen has been more sererely tried at one end of the scale than that of the masters at the other or minimum end.

Given a minimum, one of the strongest of the miners' current arguments against the sliding scale passes away. The chief popular objection to it-to quote a South Wales miner's phrase in conversation with me recently - was that "the confounded thing had no bottom.' If, however, a minimum and a maximum are first agreed upon, cannot wages between these two limits be determined by the movement of prices, i.e. whether arowed or not, by a sliding scale of some sort?

This is now the usual contention of the masters. Lord Darey, arting as chairman of the Durham Board in 1895. Was compelled to remark to Sir David Dale: "You see what your argument really comes to is this, that I ought to go back to the old sliding scale.' The

1 For the Federated Districts, sce Minutes of Bourd of Conciliation, May 1, 1902, 14. The representative of the miners there gives the following reason for a moderate maximum: "The noment the market comes down, the wages nust come down-we knew that. That is why we did not want to press, to follow up to 80 per cent. and 90 per cent., because we knew that when it reached the top there would be nothing but bother.' In Scotland (Proccedings at Conferences, May and June 1901, 81) the chief coalowners' representative, Mr. MeCosh, was very explicit. - Prices went up, and wages rose to the maximmm, and I should admit that, if an arrangement had not been made, probably we would have paid more wages for a time.' On this Lord James of Hereford, as neutral chaimun, remarked, 'That would have been a truer sliding scale.'

" Hc went on to say: "Now the old sliding scale was abolished in 1889 , because the workmen, rightly or wrongly, did not consider it fair 
convenience and simplicity of such an arrangement are certainly strong arguments in its favour. But it is worth observing that this has not always been the view of the masters. Thus in 1872 the Northumberland employers refused an advance on the ground-among others-that 'they did not admit that wages are regulated or ought to be regulated, except indirectly, by the price of the produce.' I The method of allowing wages to follow prices did break away from any immediate attention to the supply and demand of labour." Now that the sliding scale has been abolished in the North, there is an inclination on the part of the mell to appeal to the state of the labour market. Thus $\mathrm{Mr}$. Burt argued before the Northumberland Conciliation Board in 1900 that "the demand for labour is a factor as well as the price of coal in determining wages.' 3 Yet in a trade in which there is usually little complete unemployment; where slack time means fewer days for all rather than complete loss of work for many; and where the men are so completely united that none would think of offering to work at less than the county or general rate, wages camnot well be regulated

and equitable to them. So you must not ask me to go back to the old shding scale.'-Durham Proceedings, September and October, 1895, $11 \mathrm{l}$.

1 Northumberland Miners: Report of Special Council Meeting, March 1900, 111.

" In this sense Professor Munro spoke of the sliding scale as ' a striking departure by both masters and men from competition as a regulator of wages.'-Sliding Scales in the Coal Inulustry, 19 ; cf. Sliding Scales in the Iron Industry, 22.

${ }^{3}$ Northumberland: Rep. Spec. Couneil Meeting, March 1900, 64: 'Sliding scales-we are not here to depreciate them-took no cognisance of anything but the arithmetical side of the question, but a board like this can, and that is one of its many adrantages; it can take into account other important considerations, and one of the other inportant considerations that often runs concurrently with good trade and prices, but does not always run coneurrently with the condition of trade, is the state of the labour market.' 
mainly by the immediate supply of labour. And hence it seems natural to fall back on prices as at any rate something definite to go upon.

Prices, let us grant, are some sort of inclex of the profitableness of an industry, and therefore of the ability of the employers to pay wages-some sort of index of what economists call (though the general public does not) the National Dividend, or amount divisible between the parties engaged in the manufacture.

But we must first ask, what prices? Many grave practical difficulties still arise on this subject. There is first of all the difference between price quotations or newspaper prices, and actually 'realised' or' 'ascertained prices,' due to the greater or less prevalence of the practice of making rontracts some time ahead. Then there is the difference between the prices of a recent past-e.q. of the last three months, and 'current' or 'existing' prices. Thus, on the Northumberland Board in 1900, one of the leaders of the men went so far as to make the power of the board to pay regard to current prices the feature diflerentiating it from a sliding scale. 'I have always held,' he said, "that the principle of this Board was very much hisher than the principle of an arithmetical slidine scale, and that one of the principal factors of such a brard at this was to take in the prevailing prices and the conclition of trade when the board was siting, and not what had taken place four months previounly.' ' In the lirst two years of the Scotch Board it seems to have been its usual practice to pay regard to current prices; and the leader of the miners put this very clearly: : If wages must follow prices, we hold that it is on present prices

$$
\text { ' Rep. Spec. Council Mecting, } 87 .
$$


that wages should be based.' ' But if present prices, why not the expected or anticipated prices of the near future? There can be no objection to that on principle -granting that prices should regulate wages-if the anticipations are reasonably safe. Accordingly Lord Davey, in 1595, told the Durham people: 'If you are prepared with evidence of a buoyancy in trade at the present time, I an prepared to receive it as relevant fact. ${ }^{2}$ And in Northumberland the representative of the coalowners in 1900, at the end of a long discussion, declared that 'they did not so much object to the principle, to a certain extent, of taking into consideration the prices of the ensuing three months, provided it cut both ways: 3 The chief, and in my opinion conclusive, argument against such a polic $\mathrm{y}$ is that future prices are not reasonably certain. The award of Lord Davey on that occasion had to be revised a very short time afterwards, because he had assumed a 'buoyancy' which, as it turned out, did not exist. It is naturally annoying for the men to continue for three months to receive low wages when prices have risen-but they will get the rise in time if regard is paid to realised prices; just as it is annoying to the masters to be compelled for thiee months to pay high wagres when prices have fallen - but they also will get their relief by-and-by.

But still, whether past, present, or future prices are considered, they are prices after all; and in spite of what was said in the discussions, so long as any prices are followed, the principle of the sliding scale is still recognised.

It is a more fundamental question whether prices

1 Proceedings, xii. 36, 81. For the present rules see Appendix II. 4.

${ }^{2}$ Durham Proceedings, September and October 1895, 14.

s Northumberland Rep. Spec. Council Neeting, 90. 
(past, present, or future) are a sufficient index of the profitableness of an industry.

In the first place, it is conceirable that there might be a large sale at a low price, and that this might be more profitable than a small sale at a high price. This is apparently one of the ideas at the bottom of the general demand on the part of the miners that 'volume of trade' shall be taken into consideration. ${ }^{1}$

Another idea leading to this demand is that at the same price the sale might conceivably be larger or smaller, and that the larger it was-with less proportionate 'dead charges' or fixed expenses-the greater would be the profit. ${ }^{2}$ The accountants, it is understood, who are acting for the Board for the Federated Districts, have recently been instructed to prepare statistics of 'output' as well as of 'price;' and it remains to be seen what arguments will be based upon them.

In the second place, a low price of coal may be rendered possible by a diminution in the cost of production and so not necessarily mean low profits, and an increase in cost of production may render desirable an increase in price without bringing higher profits. Oddly enough this argument has been urged by both parties in different districts as against the contentions of the other side. In Scotland in 1899 it was the masters who urged it $;^{3}$ in Durham in 1895 it was the men. ${ }^{4}$ In Durham the men have refused to co-operate in the

1 In America this has been urged by the operators; see below, p. 110, n. 2. Cf. Lord Davey's remarks, Durham Procedings, April and May 1895, p. 83.

2 This is pointed out by Lord Jimes of Hereford in the Proceedings (before the Board for the Federated Districts) on December 9, 1902, 36,37 .

3 Scotch Proeeedings, 27, 71 .

${ }^{4}$ Durham Proecedings, April and May 1895, 36, 74, 76, 85. 
accountants' ascertaimments for this very reason that they are limited to selling price. 'Let the employers,' said their argument, "broaden the work of the accountants. Let their ascertainments be as complete as possible. Let them show all that affects the cost of production. Let the accountants be something more than mechanical reckoners up of a set of figures placed before them, and let them be balancers of the losses and gains of the transaction.' Whether this is possible as a piece of accounting I cannot say ; but Lord Darey the Chairman, acting as Umpire, agreed that ' a rise or' fall in prices may not indicate a rise or fall in the saleable value as a profitable merchantable article,' owing to changes in the cost of production. If a primu fucie case could be made out that this was actually so, he thought it "quite within the power of the Umpire to require information from the books of the owners as to the relative cost of production per ton of coal at one period and at another:'

If a change in cost of production took place only in big jumps and at rare intervals, it might be met by a readjustment of the scale. But the readjustment of the scale is always a most delicate and troublesome business ; and it must be allowed that we have here a valid reason for leaving the rate to the deliberations of a board or the decision of its chairman, unfettered by any formal scale.

Grant, however, that, as a rule, prices indicate profits, in what proportion are the joint gains to be shared? In ordinary times this is a purely academic question which interests economists, ${ }^{1}$ but not the parties concerned. Some employers have themselves suggested that a division into equal parts is the 1 E.g. Smart, Studies, 80, 81. 
proper arrangement, and have justified a particular rate on the gromud that it secured this end. both parties are usually quite content with rough and ready increments or decrements in wages without any exact apportiomment of the joint product. But it is when prices are ruling abnomally low or high that the dificulty arises. It is obviously desirable at the lower end of the scale that wages should not fall quite as fast as prices, and this may be balanced by a similar retardation of their rise at the upper end of the scale. Yet scales drawn up on those principles have again and again been terminated by the employers when prices fell very low on the ground that they did not give them sufficient relief, and by the men when wages were high on the ground that they did not give them sufficient benetit." The fact is that coalmasters and union leaders, able men as they are, have always legislated for the moment; and no scale has been volunturily adhered to by both sides for many years. This, it will be said, is a defect of mechanism, not of principle; but, when a lasting mechanism is almost beyoud practical possibility, the attempt to construct it may well be abandoned, even if the principle continues to be recognised as theoretically sound.

Now, however, we come to the last and most fundamentally important point of all. Grant that, as things are, with the almost unrestrained competition that commonly prevails among coalowners in most districts, prices do indicate profits. Ought prodits to be determined by prices so obtained? Ought the condition of the mining population to depend on the coalowners'

I Scotch Proceedings of $1899,25,26,68,74$. Cf. Durham Procedings, September, Oclober, 1895, 111.

${ }^{2}$ Cf. Munro, Sliding S'ales in the Coal and Iron Industries, 145. 
unregulated struggle for the market? Ultimately and at bottom, the quarrel of the miners with the dependence of wages on prices is a quarrel with the practice of umrestrained competition.

Two observations have to be made on this point. The first is that any system which makes wages 'automatically' follow prices-whether there is a formal sliding scale or not-facilitates the competition of sellers by the reduction of 'friction.' It is a commonplace among economists and statisticians that, as a rule, wages both fall and rise more slowly than prices. The resistance which he will meet with in his effort to reduce wages acts more or less consciously as a restraint upon an employer in deliberating upon a policy of low prices. But an arrangement by which wages pretty speedily follow prices without much opposition, diminishes mo tanto the restraining pressure, and leaves the employer free to follow the state of the market for the time being. This was recognised even by the earliest and most enthusiastic advocate of sliding scales among economists-Professor Munro. 'An employer,' he says, 'has not the same motive to hold back his stock of coal under a sliding scale' - and the same is true of any plan tantamount to a sliding' scale-'as if wages were regulated by competition.' It is true that he goes on to say that 'trade will be in a sounder condition the more quickly profits and wages adjust themselves to new economic conditions." 1 And it may be argued that to the workman the thing is as broad as it is long; if the employer has to wait a shorter time for wages to fall when prices fall, the workman has to wait a shorter time for wages to rise

1 Stiding Scales in the Coal and Iron Industries from 1885 to 1889. 146. 
when prices rise. This is true enough. But the workman naturally cares more to keep wages from sinking than to insure their rising. And in any case the lessening of wage-friction must tend to promote the more frequent oscillation of price. Whether one thinks, as Professor Munro thought, that that is 'a sounder condition of trade, will depend on one's general social philosophy.

The other observation is that, under the conditions which prevail in the coal trade, the existence of a formal or informal sliding scale actually tends to depress wages. It seems that it is a common practice among coalowners and middlemen to 'sell forwarl' over long periods. The extent to which this takes place is much disputed; it seems to be more general in some districts than in others, and in periods of depression rather than in periods of prosperity. I It ought not to be impossible to secure trustworthy estimates of the extent of the practice; but I do not know where to find them. Meanwhile, it is safe to say that the practice does extensively prevail, and that, so far as it prevails, it is likely to have a prejudicial effect upon wages. It is only human natme that the sellers of coal should reflect that, if they contract forward at lower prices, they will be to some extent reimbursed by a reduction of wages consequent upon the lowered price. If this is so, instead of prices being quite independently determined by other circumstances apart from wases, and then wages following suit, prices may be in some measure affected by an anticipated fall in wages, and

1 For instance, a Scotch coalowner spoke as follows in January 1901 : 'The contracts do not affect prices as in former years. Our prices last ycar were kept down by low-priced contracts, but our prices this year are not being kept up to anything like the same cxtent by higher-priced contracts.'-Scotch Conferences, xii. 30. 
then wages have to be lowered to correspond with the prices so determined. The point was well put by the leaders of the men in the Durham hearings in 1895. 'We have formed a wrong conception of a Conciliation Board if the result is only to assist competition and rush down wages.' ' And again, 'It is well known that there is a fierce underselling going on among our owners. The evil effects of this course will be seen when it is considered that the average selling price by which it is sought to reduce our wages is the joint result of those who desire to secure a fair price, securing profit to the capitalist and a . . proper wage for the workman, and those who have no such regard. Surely something better is to be expected from our attempts at conciliation. This board must not be looked upon as a safe, ready, expeditious and certain means of recoupment by those who are guilty of such actions.' -

Among the Scotch miners, the objection has been recently stated by Mr. Smillie, their leader, in the following terms: "We don't think the colliery owners are entitled to enter into forward contracts with any large corporation at a price under which they can pay the then current rate of wages, and then turn round and ask us to have a reduction of wages merely because they have entered into contracts below the price which will entitle them to go on paying the wages which we are entitled to have.' 3 ' Entitled' is a matter of opinion; but the argument itself is sufficiently clear. To these excerpts we may add the following oratorical utterances of $\mathrm{Mr}$. Brace, the Vice-President of the

I Durham Proceedings, April and May 1895, 46.

2 Ibid. September and October 1895, 26.

3 Scotch Conferences (1901), xiii. 118. 
South Wales Federation, and the leader of the recent successful assault on the sliding scale:

- The great weakness of the sliding scale was that it recognised prices as the sole factor in the regulation of wages. Was it not a fact, year in and year out, that the sliding-scale principle for regulating wages allowed, nay encomraced, men who had not invested a penny in the industry to sell hundreds of thousands of tons of Welsh coal before they had bought an ounce? This was not romance, but a great fact that condemned the sliding scale as a systen of regulating wages. When these merchants had entered into contracts to supply coal at $1 s$. less than market prices, they did their utmost to force down the market to the position which they had created, and in spite of the fact that the lower it went the greater hardships would be imposed on the men.' '

The opinion expressed by these quotations from the miners' leaders in Scotland. the North of England, and South Vales is not confined to the miners. It has been shared by a good many outside observers; "2 among others by a great coal merchant like MIr. D. A. Thomas. Even the "Times' "orrespondent at Cardiff, a strenuous defender of the sliding scale. and quite convinced that 'the great collieries in Sonth Wales, which deal directly with the Admiralty and the principal shipping lines. may safely be trusted always to get the best prices available, still confesses that "bargains have been made by middlemen from time to time, for reasons of their own, which have secmed to give colour to the

1 'The Colliery Guavdian, August 29, 1902.

2 Thus Mr. II. Read writes in the Économic Jonrnal for 1894 (iv. 333): "Coalowners make contracts at rery low rates because they know that. under the operation of the sliding seale, part of their loss will le recovered from the men's wages.' 
suggestion of cut-throat competition and unnecessiny cutting-down of prices.' 1

The controversy, then, limits itself to the extent tr, which a formal or informal sliding scale has this effect; that it has it to some effect would seem to be beyond dispute. It may be maintained, with much show of reason, that the disadvantage, so far as it exists, is more than counterbalanced by the regularity of industry which long contracts make possible. On the other hand, in a trade like that of South Wales, where a small excess in supply always leads to a more than proportionate fall in price, and the constant temptation to colliery managers is to reduce average cost by increasing output, and so still further flood the market, ${ }^{2}$ it may be argued that what is needed is to restrain rather than facilitate competition, even to the extent to which a formal or informal sliding scale may do it. The problem, as you see, does not surrender itself to simple and confident solutions.

The result, however, so far as the miners are concerned is that, for the present at any rate, their leaders on the several Conciliation Boards have everywhere declined to accept the principle that wages should be determined by prices alome. Even the highly conservative $\mathrm{Mr}$. Burt, reasoning with some ardent spirits in Northumberland, in 1900, and asking: "To what should we look except price as the main factor in determining the rate of wages?" is careful to add, "not the only one.' 3 And in Scotland the men's learler's, after every attempt in 1899 to pin them down to the

1 The Times, Janualy 1, 1908.

2 This is well shown by $M_{1}$. D. A. Thomas in his Notes on the Coal Trade 1895.

${ }^{3}$ Northumberland Special Couneil Mecting, March 1900, 111. 
proposition that, between the minimum and maximum, wages should be determined by price alone, avoided the admission by always compling' 'the selling price of coal' with 'the state of trade.' In 1902 the Scotch Conciliation Board was reconstituted and a compromise was arrived at and formulated in the following language: "The arerage net realised value of coal at the pit bank for the time being, taken in conjunction with the state of trade and the prospects thereof, is to be considered in fixing miners' wages between the minimum and maximum for the time being; and in current ordinary circumstances a rise or fall of $6 \frac{1}{4}$ per cent. in wages on the $1 S 8 S$ basis for every $4 \frac{1}{2} d$. per ton of rise or fall in the value of coal is reasonable.' The words italicised will give, it may be conjectured, abundant scope for the introduction of other considerations than prices. ${ }^{1}$

1 The present Scotch formula has been described, from the side of the coalowner's, as ' an arrangement which, if it might not guide us altogether, will at least give $\mathrm{HS}$ a very strong lead in the determination of what wages may be paid' (Proceedings, xv. 10); and from the side of the miners as 'not an antomatic system, but some method under which we could agree that reasonable grounds came in for demanding an increase or a reduction in wages' (Proceedings, xvi. 4). There has, as is natural, been some divergence of opinion between the two parties subseruently as to the weight to be attached to price considerations. Whenever the coalowners laid great stress on price, the miners protested that they had never agreed to 'an automatic sliding scale,' and the owners disclaimed any such intention on their part (itid. 72). The Sheriff of Perthshire, adjudicating as neutral chairman on July 11, 1902, thus pronounced upon the terms of the agreement: "Article 2 has not. in my opinion, the effect of fixing an inflexible sliding scale. It contemplates that the net average realised value of coal at the pit bank for the time being shall not be the sole consideration in fixing the rate of wages, but that the state and prospects of trade are to be taken into consideration also.... If it be assumed that it was intended to establish a regular sliding scale, then the coalowners' view of the agreement wouk be the logical one. But, in my opinion, whatever was the intention of the parties or a section of them, the terms of the agreement as it now stands do not support' that "argument in its entirety... The provision as to the ratio of the rise 
That this is natural and proper is now generally recognised by the employers. Thus the leader of the Durham coalowners, Sir David Dale (though, as we have seen, according to Lord Davey, he afterwards fell from grace), opened his case thus in 1895: "The interests at stake are far too large and too important to be based merely upon an arithmetical calculation. We have dealt with them by a more careful survey of the whole condition and tendency of the trade.' even the Welsh coalowners, in the draft just put before the men, go no further than to say: "In considering any proposal for an alteration in the general rate of wages, the price of coal shall be a factor.' ?

The situation is not easily summed up. On all the Conciliation Boards the representatives of the miners now insist on discussing all the circumstances of the trarle, and not prices only; and their claim is practically allowed. The consciousness on the part of coalowners and selling agents and middlemen that lowered prices are no longer quite so certain to be followed by lower wages can hardly be withont some effect in checking the tendency to cut prices in periods of depression. It is true, however, that in the recent

and fall of wages to the rise and fall of $4 \frac{1}{2} d$. per ton in the prices of the coal is not so expressed as to make that a hard and fast rule, but rather to indicate a rule for guidance, other things being equal' (Ibid. 129, 130). See the text of the Agreement in Appendix II. 4.

1 Durham Proceedings, Aprit and May 1895, 15.

2 In the final agreement this phrase was replaced by the following: 'In considering any proposal for an alteration in the general rate of wages the said minimum of 30 per cent. shall . . be consilered as equivalent to such an average net selling price per ton of large coal (not being less than 11s. 3d. nor more than 12s. 3l.) as shall be forthwith determined by an independent person.' But a new clanse was added: "Nothing in the clauses of this agreement is to preclude either side bringing any matter's before the board or independent chairman which they consider factors bearing upon the wage question.' See Appendix II. 5. 
prosperous times the miner's' representatives were content to base their demands for higher wages upon the rising prices of coal; and in $\mathrm{S}$ cotland ${ }^{1}$ they have consented to what has been happily called ' a tentative scale' for ordinary times. ${ }^{2}$

Just now in the Federated Districts the discussion turns on the means of ascertaining the state of the trade. The demand made here, and indeed elsewhere, for an inquiry into profits is simply due to the doubt whether prices are a sufficient indication of the total earnings of the industry. If it should turn out that coalowners' profits are on the average higher than those in other comparable forms of investment, a claim might be put forward for a larger share of the joint product in the form of wages. But if - what is much more probable-it should appear, in the less flourishing period on which the coal trade is apparently now entering, that depression affects profits as well as prices, then the miners may be driven back once more on their fundamental contention. 'We object,' said Mr. S. Woods, on behalf of the Miners' Federation before Lord James of Herefort in December last, ' and have always objected, to wages being governed by prices on this one ground, that we have no voice whatever in fixing the prices-they are fixed absolutely without consulting the workmen.' 3 And in the same sense Mr. Brown, the Secretary of the Scottish Miner's' Federation, a year or so ago: "In dealing with wages in relation to prices, I think it ought to be borne in mind that there are 70,000 miners in Scotland, and they have 110 say as to what the price of coal is to be.' 4 of

1 And now in South Wales? 2 Scoteh Proceedings. xvi. 188.

'Minutes of Mecting of the Board of Conciliation, December 9, $1902,34$.

4 Scoteh Procedings, siv. 24.5. 
course the miners' leaders will be just as loth, when profits are low or non-existent, to have wages governed by a trade policy in which they have had no 'say,' or 'voice.' What they are driving towards is nothing so foolish as interference with the conduct of particular businesses. What is vaguely floating before them is a 'regulation of the trade' as a whole, in which they shall take a formal part. Certainly the only means of mitigating the severity of recurrent crises in the coal trade is by slackening output when the decline of prices begins. Evidently the coal trade could not by itself rise altogether superior to a general depression, affecting, let us say, some of the chief coal-using industries. But it might be so regulated as to bear the stress more easily; and if its example spread, seasons of severe general depression might become things of the past. I have already quoted some expressions of willingness on the part of the miners to join in the regulation of the trade; in Durham some years ago they even demanded that their wages should be regulated only by the prices of the short-lived Sales Association. ${ }^{1}$ Probably the form of 'regulation' which will first be resorted to will be a checking of output by means of 'stop-days;' and if the coalowners are reluctant to adopt this measure, the men will doubtless attempt to carry it out by their own organised strength. If the recent decision of Mr. Justice Bigham in the South Wales 'Stop-day' case remains law, the Miners' Federations will have no penal-

1 " We recognise the worth of the Coal Sales Association, and repeat our assertion that had not some of the employers remained outside, and forced down the prices, this reduction would not have been required. If this be disputed, let the employers base their claim upon the prices realised by the Coal Sales Association alone. Otherwise we are at the mercy of a system of competition which cannot be stopped by the present reduction.'-'Workmen's Rejoinder' in Durham Proceedings, April and May 1895, 69. 
ties to fear in adrising their members to the amount of breach of contract involved in an occasional general holiday. ${ }^{1}$

But it is only six years ago that the great majority of the South Wales coalowners were ready to join with the men in a scheme for restricting the output; ${ }^{2}$ and similar co-operation between coalmasters and coalminers is not at all unlikely in the future. Or there will be some mole formal alliance there and in other British coal fields. For it will evidently be towards some

1 The decision of Mr. Justice Bighan was full of the unexpected. In consequence of recent legal rulings (see below, Lecture VIII.) the South Wales Miners' Federation had anxiously songht to make it appear that the advice in question did not proceed from itself but from the miners' members of the South Wales Sliding Scale Committee. Mr. Justice Bigham pushed all such pretences on one side and fixed the responsibility where it evidently belonged. But then he went on to lay down that for giving such advice-although it led the men to break their contracts in the sense of staying away from work one or two days-the Federation was not liable in tort. "I find that the Federation and all the other defendants acted honestly, and without any malice, and in ordering the stop-days did no more than that which they conceived to be in the best interest of the men whom they represented, and for whom they were acting; and I find, moreover, they had lawful justification or excuse for what they did in this, that having been solicited by the men to advise and guide them on the question of stop-days it was their duty and their right to give the advice, and to do what might be necessary to secure that the advice should be followed.' I quote from the verbatim report in the Colliery Guardian for Angust 15, 1902. The whole argument of the judge should be read.

2 Compare the comments on Mr. Justice Bigliam's decision of a writer in the Colliery Guardian for August 15, 1902: "It is necessary, fully to appreciate this conclusion, to go beyond what appears in the judgment itself and to lay empliasis upon the fact that the coalowners have, in previous years, joined with the men in an endeavour to regulate the out. put. Both in 1896 and 1897 a committee (first of the associated sliding. scale owners and afterwards a committee which included non-associated owners) considered and approved, and in 1897 actually drafted and recommended a scheme for keeping up prices in South Wales by limiting the output. Obviously these are facts which must have weighed heavily in the judge's mind. The men have done what the master's were willing to do in 1897, but for the fact that the required percentage of adherents to. the scheme was not secured.' 
arrangement for restraining competition that the logic of the situation will point.

${ }^{1}$ Meanwhile it is not, I should think, even from the miner's' point of view, altogether to be regretted that the recent attempt of the Miners' Federation of Great Britain to induce the Welsh miners to make an agreement with the coalowners for one year only, should have met with ill success. The intention was that the three agreements for the Federated Districts, for Scotland and for South Wales, should be made to terminate at the same time, and thus an opportunity be given for the creation of a single board, which eren Northumberland and Durham might conceivably be induced to join. Whatever may be said for such a grandiose conception from the miners' point of view, I cannot but think that the experiment will have a better chance of success when the several boards already in existence have had a longer experience, and especially when they have led to the more distinct formulation of a wage policy suitable for times of depression. 


\section{LECTURE IV}

GENERAL RATES AND THEIR INTERPRETATION.

THE HOURS OF LABOUR

LET us now look more closely at the constitution of the boards. That for the Federated Districts consists of an equal number, fourteen on each side, of representatives of 'the Federated Coalowners' and of the Miners' Federation of Great Britain-' with a chairman from outside who shall have a casting vote.' 'All questions,' run the rules, 'shall, in the first instance, be submitted to and considered by the board,' i.e. in the absence of the chairman, "it being the desire and intention of the parties to settle any difficulties or differences that may arise by friendly conference if possible.' 'If the parties on the board cannot agree,' then the meeting is adjourned and the chairman summoned, the matter again discussed, and, in default of an agreement, 'the chairman shall give his casting vote, which shall be final and binding.' It is provided in the joint agreement that, when the office of chairman becomes vacant, "the board shall endeavour to elect another chairman, and, should they fail, will ask the Speaker for the time being of the House of Commons to nominate one.'

The rate fixed by the board at its initiation in 1894, viz. 30 per cent. above the standard of $18 s 8$, remained unchanged until the autumn of 1898 . From that time onward wages were successively raised $2 \frac{1}{2}$ per cent. above 
standard in October 189S; 5 per cent. in April 1892; $2 \frac{1}{2}$ per cent. in October $1899 ; 5$ per cent. in January 1900 ; 5 per cent. in October 1900 ; 5 per cent. in January 1901 ; and 5 per cent. in January $1902^{1}$ reaching therewith the maximum, 60 per cent. above standard. All these advances the board was able to agree upon by itself, without calling in the assistance of its neutral chairman. But things have not gone so smoothly since the ineritable reduction in coal prices began.

In May 1902 the board manimously agreed to recommend a reduction in wages of 10 per cent. (to take effect ; per cent. in . June and j per cent. in August). But, although it does not appear in the Rules of Procedure, ${ }^{2}$ neither party on the board apparently regards itself as possessing unlimited 'plenipotentiary" powers. Exactly how far they suppose they can go without referring to the bodies they represent is not clear. During the rise in coal prices the coalowner representatives had frequently to go back and consult their constituency before granting the increased wage demanded by the miners. And now in 1902 the recommended reduction had to be laid before the men. The men by a large majority refused to accept the recommendation of their leaders. ${ }^{3}$ Accordingly it became necessary to

1 These were not all separate agreements. The board agreed more than once to spread the advances orer a period of some months.

2 For which see Appendix II. 1.

${ }^{3}$ Yorkshire roted against accepting the recommendation by a majority of almost nine to one; Lancashire and Cheshire alınost unanimously; Derbyshire by a small majority. On the other hand, all the districts in the Midland Federation proper 'decided to leave the whole ease in the hands of the Federation Board, as they had full confidence in the Board,' and the same was the opinion of Nottingham. The voting seems to have been, as a rule, by the 'Comncils,' at the rate of one vote for fifty members.

Four years before, when the rise began, the officers of the Miners' Federation had found considerable difficulty in carrying the men with 
invoke the services of the neutral chairman-Lord James of Hereford, who decided upon a reduction of 10 per cent., to take effect in July. It is evident that the party which has been unable to carry its constituents with it is in a very embarrassing position in the subsequent arguments before the neutral chairman. Even if in the earlier discussions they thought they had a just claim for better terms, and only yielded for the sake of peace, the fact that they did yield inevitably diminishes the effect of their subsequent arguments against the arrangement. And yet their duty to the societies, whose paid executive officers they are, compels them to do their best as adrocates.

In November the board was again called, this time in consequence of a simultaneous application of the miners for a 10 per cent. increase and of the coal. owners for a 5 per cent. reduction. Agreement was impossible, and the neutral chairman was at once called in and heard arouments on December 9 last. His decision has hitherto ${ }^{1}$ been deferred, awaiting certain returns from the accountants which both parties have agreed to call for.

In Northumberland the constitution of the board is much the same: here it is fifteen on each side. Here

them. "When the agreement for a $2 \frac{1}{2}$ per cent. advance was reached in 1898 the men did not like it, and some who were on the Conciliation Board were not satisfied. Others who were not on the board liked it still less and criticised the action sererely and bitterly. especially in Lanca. shire. The men took a ballot to decide whether or not they would accept and approre the decision of the board. Some of the delegates opposed it actively, declaring that their representatives on the board had been outwitted. At that juncture Mr. Pickard and others issued a manifesto requiring courage, in which they declared that the decision was a boon to their interests and should not be declined. It was accepted.'-McPherson in Bulletin 28 (May 1900) of the U.S. Department of Labor, reporting a statement by Mr. Ratcliffe Ellis, the Coalowners' Secretary.

${ }^{1}$ Until, indeed, the end of April 1903. 
also there is 'an independent chaiman;' and the County Court Judge for Northumberland, Judge Greenwell, has been chosen by the two parties. 'In default of agreement by the two parties' the chairman 'shall have power to decide such question as he may see fit, and his decision shall be final and binding on all parties.' But in Northumberland, apparently, the chairman is expected to preside at ordinary meetings. At most of the quarterly meetings which have taken place since the re-establishment of the board in 1900 , some change has been made in the county rate. At first there were advances; but since February 1901 there have been reductions; and in two cases out of three the board has been compelled to leave the matter to the decision of the chairman.

It is obvious that under such circumstances, both in the Midlands and in Northumberland, the chairman tends to become an arbitrator. The proceedings seem to differ from the arbitrations of an earlier period in that, (1) an attempt is always made first to settle the matter by regular negotiation between the parties in a formally constituted board, (2) when they fail to agree, there is a permanent chairman to fall back upon, and no time need be lost or difficulty created by preliminary contentions as to who shall be called in, (3) the chairman is limited to a range of wages between a maximm and minimum, (4) by the decisive rejection of the sliding scale the chairman is wamed beforehand against a merely 'mathematical' determination of wages by reference to the realised prices of the last quarter. In spite of these differences, however, there is a real danger that the habit of appealing to the neutral chairman's decision may seriously weaken the Conciliation Boards. Men are not likely to put their contentions into a con- 
ciliatory shape or to give patient attention to the arguments of the other side, if they start with anticipating that the whole matter will have to be gone over again before the neutral chairman. This contingency would be less likely if the miners' representatives had authority to come to an agreement without referring to their constituents; and it is on the growth of a more distinctly representative organisation on each side that we must rely for the more adequate fulfilment in the future of the functions of the boards.

In Durham, for reasons which are not apparent, and which can only be conjectured as personal, the two parties on the board since its reconstitution in 1899 have managed to agree on each of the long series of quarterly changes (all of which, in this comnty also, have been reductions since February 1901), without calling in an outsider. Each side is represented by eighteen; one of the owners' representatives acts as chairman, and one of the miners' representatives as vice-chairman-each with a representative and not a casting vote. The language of the rnle 'as to the desire and intention of the parties' is the same as that of the Midland Board; but the Durham men have frankly recognised the logic of the situation and call the ontside arbitrator not 'neutral chairman' but 'umpire' -which he really is.' They appoint their umpire ammally, and by manimous consent have each time elected Lord Davey; but so far they have had no need for his services on the present board.

My time will not allow me to deal with the Scotch Board, except to say that a reduction of so large an amount as 25 per cent., recommended to the men by

1 It is significant that in some of the circulars of the Miners' Federasion Lord James of Hereford is spoken of as 'Umpire.' 
their representatives on the board, was accepted after a ballot of all the 70,000 miners employed, in March 1901. But since then the board has three times failed to come to an agreement, and has called in as neutral chairman Lord James of Hereford on one occasion, and on two occasions the Sherift of Perthshire.

The rates fixed by the boards or their chairmen are all general, or (in Northumberland and Durham) county, rates. They determine primarily the wages of the hewers (or cutters of coal), and these are followed in certain proportions by the other classes employed. But they do not settle the exact rate per ton to be paid to the individual miner: they only determine what he shall be able to earn, by normal exertion, in a normal day, at the rates actually current in the particular mine and seam. The changes in the general rate are sometimes so marked and the character of the men's labour so evident that a readjustment can readily be effected. But often it is very difficult; and the manager of a mine may believe himself to be paying above the proper rate, or the men believe themselves to be paid below. Some machinery, therefore, is necessary for the interpretation of the general agreement and its application to unusual or exceptional circumstances. It is here that the Northern Counties distinguish themselves for the excellence of their arrangements. All such questions in each county are settled by a small Joint Committee of six from each side with a legal chairman. These are not the magnates of the coal trade or Miners' Association: they are the ordinary officials of the two parties, men of technical coal-mining knowledge, not necessarily of commercial knowledge. The disputes are often so 
technical and remote from general consiclerations, turning upon the relative hardness of different kinds of coal and the like, that an employer's' official is sometimes delegated to look into a matter and his report accepted by the men's representatives, and sometimes similarly the employers' representatives entrust the matter to a miners' representative. These joint committees have gone on doing their work for more than a quarter of a century, interpreting the srates whatever they may be at the time and however settled. This is one of the greatest triumphs of common sense the industrial world has yet seen. The joint committees, indeed, are not uniformly successful; local stoppages do occasionally still take place when the men refuse to listen to their officials; and serious strikes may still occur in those few rollieries not in the Coalowners' Association and susceptible to its pressure. ${ }^{1}$ Nevertheless the joint committees succeed in maintaining the peace on the whole. It is the only part of the mechanism for adjusting wages that the ordinary manager comes in contact with. The high questions of policy involved in the comnty rate are settled above his head; and when he cannot come to terms with the local pit branch, he falls back with a sigh of relief on the joint committee. Being human, managers still sometimes speak as if they were hampered by this arrangement. But let there come some trouble in the Midlands, and they at once pride themselves on the existence of the joint committees as evidence of the superior wislom of their own northern counties."

${ }^{1}$ An instance in which 127 men were engaged is conmmented on in the Durham Miners' Monthly Circular for December 1899.

${ }^{2}$ For the Durham Joint Conmittee Rules, see Appendix II, 3A. An interesting and quite eulogistic account of the working of the committee will be found in Professor G. von Schulze-Gacvernitz's Social 
Outside the two northern counties no such mechanism exists for interpreting general agreements and applying them to particular cases. So far as the work is done at all, it takes the form of negotiation between the mine manager and a union functionary known as the 'Miners' Agent.' Thus the Camnock Chase Miners' Association, with its thirty pit branches and its 4,000

Peace (1893), 173-186. Another account is given in Webb, Industrial Democracy, 192-5, where the tribunal is described as 'impartial,' but 'cumbrous, expensive, and dilatory for deciding mere issues of fact.' That the system involves some delay is apparently true. Giving evidence in 1891 Mr. Patterson, the Secretary of the Durham Miners, said that of late the number of cases had been inereasing so rapidly that they some. times conld not be disposed of by the committee for six months; and Mr. Wilson spoke of six weeks as a quite likely delay if a case was not reached on the agenda.- R. Com. on Labour, Group A, i. 5, 30. I am informed by Mr. Wilson that 'in these later years' the business of the Durham Joint Committee has not been so congested as in 1891. The argument of the Webbs that the work conld be done more effectively by conference between a single professional expert on each side, as in the cotton industry, is hardly convineing; for one can hardly suppose that the circumstances are so readily reducible to arithmetic as the counts of varn and other technical 'particulars' in the textile trades. For the manager's point of view see Bulman and Rednrayne, Colliery Working and Management, 80-81. From the latter work I extract the following table showing how the 761 cases brought (578 by workmen, 183 by owners) before the Joint Committee in Durham in 1894 were dealt with :

Referred to local arbitration 76 Per cent.

Settled by agreement between two parties in dispute . . . . . . . .

Decided by committee . . . . .

Withdrawn · · · · ·

Fuled as being ont of jurisdiction of committee

\begin{tabular}{rr}
225 & 29 \\
205 & 27 \\
242 & 32 \\
13 & 2 \\
\hline 761 & 100
\end{tabular}

A most elaborate abstract of Joint Committee Decisions, Agreements, Awards, Reports, Practices, Rules dc. has been prepared in a number of rolumes by the officials of the Durham Miners' Association; and the 'lodges' are urged to consult the precedents thins provided before sending in any case to the Joint Committee. Similar Minutes of Joint Committee proceedings are furnished to its members by the Coalowners' Association, and are filed by colliery managers. 
members, has for its one permanent paid official an 'Agent' whose business it is to discuss grievances with the employers, and to appear for the union at the annual congresses of the Midland Federation and of the general Federation of Great Britain. The same is true of most of the unions which compose the Midland, Scotch, and Welsh Federations In several cases in recent years coalmasters and unions in these districts have taken advantage of the Conciliation Act of 1896, and have applied to the Board of Trade to appoint a Conciliator. In some of the cases both parties have concurred in asking that the appointed person should act as Arbitrator and give a binding award. The representative of the Board of Tralte has usually been able to settle, or facilitate the settlement of, the dispute; and this is so far satisfactory, especially when the appeal was made without stoppage of rork. But as recourse to the Board of Trade has probably meant as a rule the failure of the means nearer at hand, the circumstances would seem to indicate that the Agent system does not work so well as the Joint Committee system of the Nolth-from which no appeals came."

So much then for the mechanism for the determination of wages. But you will remember my remark that the divergence between Yorkshire and the northern counties was not entirely a matter of wage policy. And there is one subject of contention too momentous to be passed orer, and that is the period of labour. The Federation of Great Britain pursues with ardour the policy of legislative limitation of the hours of labour, and demands a statutory eight-hour day :

1 See 1st, 2 nd, and 3rd Reports of the Board of Trade of Proceedings under the Conciliation Act, 1896 (1897, 1599, 1901). 
the miners of Durham and Northumberland steadily oppose the demand, and their representatives not only argue and vote against the Eight-Hours Bill in Parliament, but display the even greater courage required to resist the proposal in the International Miners' Congresses. But for the opposition of the northern miners and their determination, if the bill must pass, to exempt themselves by local option, a statutory eighthours day in mines, 'from bank to bank,' would already have been established in England. And the situation becomes the more perplexing when we learn that the northern miners themselves work a good deal less than eight hours.

The explanation is not really to be found in any theoretical objection to State interference, or in any belief that trade-union pressure is less injurious to individual liberty than State compulsion. Principles of this kind, though they may be sincerely expressed by the leaders, are too abstract to sway the mining ponnlation of a couple of counties. The northern miners, indeed, have never been backward in demanding State interference when they thought it for their interest. The explanation lies in the conditions of northern labour. There the double-shift system prevails as the usual arrangement, and each shift is short. Everywhere else, though night shifts are worked at busy times, there is usually only one day shift, and it is long-nine or ten hours. But the labour of the men involves the labour of boys in loading the cars, \&c. The first shift going down in the North at, say, 4 A.м., the hewers will not have cut enough coal for the boys to have much to do until about 6 ; so the boys go down and besin work then. But the first shift coming up at about 10 , the boys can hardly leave then, after 
only four hour's' work, and so they are kept on until the second shift comes up at 4 P.M. ; and they are thus ten hours underground. The long hours of the boys are, therefore, conditioned by the short hours of the men: if the men worked a single long shift the boys could have a short day's work. How far, then, is it true to say that the boys are sacrificed to the men? This is a question to which one ought to be slow to give a positive answer without personal investigation. The work of the boys is certainly much lighter than that of the men: and as the boys are the soms and brothers of the men themselves, who have many of them been through the same experience, one can hardly suppose that the ten hours' work involves grave physical strain. But an eight-hour day for the boys would necessitate a complete reorganisation of mining labour: some of the miners believe it would lengthen their own working day: nobody in the North sees his way throngh the impasse: they think well enough should be left alone; and they are irritated that mere Yorkshiremen should set up to teach them their duty! It is unfortunate for the Eight Hours cause that the generally superior cunditions of the North should thus block the way. It is possible, however, that the more general application of recent improvements in the methods of hauling coal, and especially the introluction of electrical traction, may diminish the need for boy labour, and that the problem will thus becone more manageable. ${ }^{1}$

But this opposition of the northern miners does not

1 Even at present it does not seem a huge one. According to the Home Office Mineral Statistics for 1901, ii. 54, boys between the ages of thirteen and sixteen formed only 5.7 per cent. of the persons employed in the northern coal field. 
account for the opposition of the coalowners, especially in the other, the Federated, districts. They oppose it on the ground that a limitation to eight hours wonld cause a diminution of the output. The statement presented by the Representative Coalowners at the recent Conference (December 1902) with the Miners' Federation was as follows:

- We are satisfied that we are considerably within the mark when we say that the decreased output which would result from an eight-hours bank-to-bank day wonld not be less than from 11 to 18 per cent. at the most favoured collieries to as high as 30 per cent. at those less farourably situated. We should be within the mark in assuming a general average reduction of output of 25 per cent.' They proceed to argue that 'the standing expenses of a colliery distributed over' a smaller output means increasing the cost of every ton raised.' They point out that mnless the tomnage rates of wage were increased, which the Federation does not ask for, a diminished output means reduced earnings. If, on the other hand, tonnage rates were raised, this would still further increase the cost of getting the coal.

This is the main contention of the coalowners; and, on the other side, though there are some who assume a smaller ontput per man per day, and adrocate the restriction as a way of securing steadier employment, the Miners' Federation as a body denies that a smaller ontput will result, and bases its case on the desirability in itself of a shorter day's work.

The coalowners' argument is the same as has been urged by the employers against every reduction of the hours of labour. It ought not, therefore, at once to carry us off our feet. On the other hand it is not, 
therefore, to be disregarded. Reductions of time in the past, in this as in other industries, have not, as a matter of fact, caused a reduction of output. Isut, unless the arts of production so improve that ultimately no human labour at all is required beyond the pressing of a button, it is obvious that somewhere a point must be reached when labour camnot be curtailed without affecting produrt. The question in any particular. case is whether or not that point has been reached. 'The matter is an exceedingly complicated one, and involves many other ronsiderations besides the speed of labour at the face of the coal. It involves, for instance. the question of meal-times; and the more important questions still of the efficiency of the hauling and winding nachinery. If everything remained unchanged but the hours of labour, it may be readily granted that output would diminish. But will everything remain mohanged? It would be foolish to dogmatise; but it maty be observed that what is, so far as I know. the most thorough discussion of the subject, that by the late Professor Munro, ${ }^{1}$ reaches the conclusion that other things would not remain the same. Economies of time. improvements of machinery. and other like consequences of the proposed legislation would, in his opinion, result in the maintenance of the present output. Professor Munro's conjectural summation of probabilities is borne out by the results of recent American experience. An eight-hour day was obtained in 1898 . by the miners in the chief bituminous coal fields of the United States. The day is one of eight hours 'at the face' of the coal, which is not the same as from 'bank to bank; nevertheless the change was a reduction of labour-time. and

"Economir Joumal. i. (1891), 281. 
might have been expected to affect production. And the coalowners (or 'operators' as they are called) in the older fields around Pittsburg did maintain next year before the Industrial Commission that the men did only four-fifths as much in eight hours as in ten. Yet it seemed to be the general opinion in newer coal fields, with newer plant and more fresh enterprise among the coalowners, that the output had been little if at all diminished. Thus a large mineowner from Ohio reported as follows: "When the mine is prepared to take care of the coal, I believe, in our Massillon district, the miner can mine as much as he could before in the eight and a half or nine hours, because a large part of that time he was waiting for cars, or something of that kind. It depends largely upon the equipment of the mine for taking out coal. If the coal can be handled promptly, the miners can produce as much in eight hours as they did before in nine or ten.'

Q.--Has the shorter workday had the effect of improving the mine equipment as a general thing? A.--I think it has.' an example from one of his own mines where "we had increased our ability to handle coal by the addition of a double-decked cage in place of the single-decked, which enabled us to hoist two cars at a time instead of one, and gave us an opportunity to get out more coal in a given time than we could before.' ${ }^{2}$ In Scotland,

1 Report of the U.S. Industrial Commission, xii. 171.

2 Ibid. 110. Cf. the account of the way the eight-hour day was carried (on the motion of a leading operator of Pennsylvania, Mr. Pobbins) in the Chicago Convention of 1898, in Mr. J. E. George's article in the Quarterly Journal of Economics for July 1898. See also the letter there given (457 note), from a prominent operator in Northern Illinois: 'The men are adjusting themselves to the eight-hour day, and, though not getting out as much coal as in ten hours'-this was only six weeks after the 
also, it may be observed the eight-hour day has been universal since Jamnary 1900 ; though there it is eight hours at the face, i.e. allowing half an hour for breakfast, about seven and a half hours actual work.

Noborly, however, not even the English War Office, likes to be compelled to become more efficient against his will; and the necessary initial expenditure, though it may be more than repaid in a short time, may be hard to comprass in the less profitable among the midland mines. The coalowners lay stress upon the great differences that exist between collieries, and the hardship that the reduction of hours would cause to some of them, especially those who work the thimner seams. Legislation in this direction, like legislation or tradeunion pressure in other directions. would probably tend to crowd ont not only the incompetent managers but also the smaller capitalists, and help forward that absorption of the smaller by the bigger concerns to which many look for a better organisation of the coalmining business from top to bottom.

change had bcen male - 'have increased their output considerably, owing to the fact that they have learned how to get their coal ready in shorter time.' 


\section{LECTURE T}

AMERICAN COAL FIEI,DS AND JOINT AGREEMENTS

From Great Britain let us now pass over to the United States.

In considering the production of coal in that country we have, to begin with, to draw a sharp distinction between the bituminous or soft and the anthracite or hard variety. This distinction, which we may forget in Great Britain-since our supply of pure anthracite is so small as to be almost negligible-is of the utmost importance in the Lnited States, where anthracite still forms almost one-fourth of the total output. ${ }^{l}$ Let us clear the geography out of the way by saying that the anthracite of the United States is practically a monopoly of Eastern Pemnsylvania, which produces 99.9 per cent. of the total quantity mined. Anthracite is still of rast consequence to the country. but its relative importance is markedly diminishing. Its output has hardly doubled in the last twenty years, while that of bituminous has been multiplied almost five-fold. Hereon hangs the story of one of those vast transformations of industrial activity which have characterised the past century, and most notably in America. Down to about 1840 the small quantity of iron prodnced in the United States was smelted with charcoal; this process sur-

1 About 473 million 'long' or 'gross' tons (of 2,240 lbs.) in 1898, out of not quite $196 \frac{1}{2}$ million tons; in 1899 , not quite 54 million tons out of under 231 millions ; in 1901, 60 millions out of under 261 millions. 
viving, after it had disappeared in England, owing to the abundance of wood. About 1840 anthracite coal began to be used for that purpose; this being rendered possible by the introduction at that time of the hot blast. From 1840 to 1870 , roughly, was the period of 'anthracite iron; ' and during this time Eastern Pensylvania, which produced both iron ore and coal, was the main coal and iron producing district. But about 1860 bituninous or soft coal began to be used for smelting purposes; by 187.5 its use caught up with that of anthracite; and since then the huge advance in the iron product of the United States has been dependent on the use of coke " nade from hituminous coal)." Thus in 1898 more than $10,000,000$ tons of pig-iron were smelted with bituminous, 1,000,000 with anthracite aur coke, a quarter of a million with charcoal, and not one-tenth of a quarter with anthracite alone. The explanation is to be found in the greater cheapness of the mamufacturing qualities of soft coal. Anthracite is limited in supply, and the landowners are able to secure a larger royalty; it is placed deeper in the earth and requires more expensive shafting and tunnelling; and it needs expensire machinery for breaking, while soft coal can be sold 'run of mine' or 'screened. The cleanliness and freetom from smoke which are characteristic of anthracite have made it the farourite domestic fuel with the whole population of the eastern half of the United States; and as houses are all supplied with stoves and furnaces saited for the consumption of hard coal and not for soft, even a temporary stoppage of supply causes widespread discomfort. But the manufacturing kinds of soft coal are much cheaper;

1 Taussig, Tariff History of the U.S., 128 seq.

2 Taussig, Quarterly Joumal of Economies, xiv. 147. 
and, for that and for other reasons, hard coal is being rapidly displaced by bituminous both for smelting, for use under boilers, and for other industrial purposes. As a consequence, Pittsburg, which is in the heart of the soft coal district and within fifty miles of the most important coke-making region, that of Comnellsville, has become the greatest iron and steel centre of the United States.

Pittsburg is in western, not eastern Pennsylvania; separated from the eastern or anthracite field by a couple of hundred miles or thereabouts. And while Eastern Pennsylvania has a monopoly of anthracite, Western Pennsylvania still produces some 40 per cent. of the total bituminous output. Thus Pennsylrania is even to-day much the most important of the mining states. But the coal region extends beyond the borders of the state, and stretches southwardly and westwardly into Maryland, West Virginia, and Ohio-West Viryinia being third in the order of coal-producing States, with $9 \frac{1}{2}$ per cent. of the total bituminous output, and possessing the celebrated Pocahontas steam coal. Continuing along the Appalachian highlands, roughly parallel with the coast, coal is found in Kentucky, Tennessee, and Alabama; and the production of the latter state is growing rapidly, especially around the new city of Birmingham. But, for the present, operations in these states are comparatively limited.

The two other most considerable fields outside Pennsylvania and the adjoining states we may speak of as the Central and Western. The Central occupies about half of Illinois, a considerable region in Indiana, and a portion of Kentucky. Illinois produces almost 12 per cent. of the total bituminous yield, of which a good deal goes northward to Chicago and westward to 
St. Louis. The Western deposits are being increasingly worked in Iowa, Missouri, and Kansas, and these states furnish rather more than $T$ per cent. of the whole.

Before describing the organisation of labour, the map suggests some preliminary observations on the general situation of the coal industry in the United States. It is an industry which has. until recently, stimulated to the very utmost all the tendencies towards individualism which are already so strong in that comntry. I use 'individualism,' let ne remark, in neither a good nor a bad sense; I ust it for that readiness, that determination, to go one's own individual way, which one characterises as enterprise or money-making, selfreliance or self-conceit, rugged strength or angularity, according to the circumstances and one soint of view. Elsewhere I have tried to show how this spirit of individualism was created in America by the circumstances of its early history." And certainly the coal industry for the last thirty years has provided it with a congenial enviromment. Keen competition is almost inevitably called forth when the demand for a commodity is increasing, in its amount and widening in its geographical area and when the field of possible production is opening out with equal rapidity ; and this has for some time been the general tendency in the coal trade of the United States, even if the development has not been absolutely continuous. As to the demand, the growth of the railway system and the filling up of the West, the increase of the population, the growth of the cities, the rise of manufactures, and, especially cluring the last

1 These percentages refer to 1898 , and are taken from the Coal Trade of the U.S., issued by the Burean of Statistics, U.S. Treasury, 1900.

2 Surveys, Historic and Economic, 405-421. 
few years, of the iron and steel trades-all these intercomnected phenomena have meant the appearance of a vast demand which promises fortunes for those who can supply it. If, indeed, the coal deposits had been limited or difficult to work, the supply might have soon fallen into a few hands, and been early subject to some sort of regulation. But the deposits are enormous. Even the anthracite production has easily outstripped the anthracite demand; and there is plenty of coal-land yet to be 'developed.' Bituminous coal has been found more and more widely distributed; it is now mined in half the States of the eastern side of the country; it lies near the surface, and is cheaply extracted; and the older districts have been subjected to the keen competition of quite new rivals in younger states. Think what these facts must have stood forthat West Virginia mined in 1880 about $1 \frac{3}{4}$ million tons, in 1900 over $22 \frac{1}{2}$ millions ; or Alabama not much more than $\frac{1}{4}$ million in 1880 , and more than $8 \frac{1}{4}$ millions in 1900. Of course there is competition in Great Britain, and the output of some fields, as we have seen, has grown more rapidly than that of others. But all these conditions appear in the Cnited States in a form far more acute. And what does keen competition mean? It means that,-given the alternation of periods of prosperity and depression, an alternation which, though now retarded and now hastened, seems well-nigh as regular as the movement of the ticles,-there are bound to be recurring seasons of over-production. To meet demand at times of great prosperity fresh mines are opened, new machinery introduced, more men engaged; and then, when depression follows, there is a 'capacity' far in excess of the demand. Moreover-and this applies especially to 
the anthracite mines-the accumulation of fixed capital itself leads to excessive production at stagnant seasons, since it is usually more economical to work a mine so long as anything at all can be earned over running expenses, or even for some year's to run it at a loss, rather than close it entirely. Add to this, that the seasonal variations in demand, which everywhere perplex the coalowner, are even more troublesome in a country with a continental climate-a climate, that is, marked by great extremes of heat and cold: and we have no difficulty in explaining the ups and lowns, the great successes and the great losses, the recklessness, the jealousy and irritation, that have attended the development of America's coal resources.

All this strengthens the natural tendency of employers everywhere to feel personally aggrieved by demands for higher wages. Many coal operators undoubtedly get their labour as cheaply as they can, and give no thought to the lives of the people they employ. But there are scores of high-mincled, public-spirited, God-fearing, philanthropic men, feeling keenly the stress of competition and spending anxious days in scheming against their rivals, who think that they are benefactors to their race simply by 'giving employment,' and who resent a strike as positively ungrateful and, as it were, a mutiny in the face of the enemy. They feel this the more because the greater mobility of American society, the more numerous business openings, the temptations toward political service and political office, are constantly depriving the manual labouring classes of their natural leaders. Here is a passage from a recent book by $\mathrm{Mr}$. John Graham Brooks, who has made it his business, for some years past, to get into close touch with all labour move- 
ments in America of any real significance: "I can count from memory thirteen men in Massachusetts, who were in their time and place leaders, who now occupy positions in politics or business. A friend tells me that in Chicago he knows of more than thirty men, formerly at the front in their respective unions, who now hold political office in that city. . . . At Pittsburg, during the steel strike, I tried to find some of the ex-presidents of the strong trade-union there. The most important of the former officials had gone into other occupations.' 1

The establishment of satisfactory relations between employers and employed would thus have been a slow and arduous business in any case; but all the difficulties we have already noticed have been enormously increased by the fact that mining labour is very largely foreign and non-English speaking. In 1830, 58.1 per cent. of the miners in Pennsylvania were foreign-born, 57.4 per cent. in Illinois, 59 per cent. in Ohio." Originally the immigrants into the mining districts were English, Scotch, or Welsh; but about $1875^{3}$ the stream began to flow from Hungary, Bohemia. Poland, and Italy, until these countries now furnish the bulk of the mining population. Thus the chief coal company $1 n$ the anthracite district employed in 189017 per cent. of Polish 'nationality and parentage' 21 per cent. in 1895,24 per cent. in $1896 ; 5.9$ per cent. Hungarian in 1890,10 per cent. in $1895,11.2$ per cent. in $1896 .^{4}$ The advent of the 'Hun,' as the Hungarian is commonly called, has been very welcome to the employers.

1 Social Unrest (1903), 4.

" Report of the U.S. Industrial Commission, xv. Intro. xxxiii.

${ }^{3}$ Virtue in Bulletin 13 of the Department of Labour (November 1897), 749 .

${ }^{4}$ Rep. Ind. Com. xr. 392. 
It gives them for a time cheap and docile labour; it has enabled them again and again to defeat the unions; in the soft coal fields it has facilitated the introduction of coal-cutting machinery. It is probable that at first the operators directly or indirectly assisted immigration. 'The importation of 'contract labour' was, however, marle illegal in $1885 ;{ }^{1}$ and, indeed, it has not been necessary for some years past for the operators to trouble themselves about the matter. Once the stream was set flowing, it continned to flow; and this would seem to indicate that, however bad the conditions might be under which the new comers worked, they were better than those in their own country." After a time, too, their standards of living begin to rise. But it is none the less true that their arrival has seriously endangered, and in places destroyed, the native American standard of living; and any one who is interested in the theoretic question as to what deter-mines the rate of wages, and wants to make out a case for the 'standart of comfort,' may be advised to turn his attention to the story of immigration into America. It may easily be imagined that the foreignness of the labour does not tend towards mutual sympathy and appreciation between employer's and employed; and though most of the foreigners are decent and usually docile folk, they have had little experience in the art of self-govermment; and their proneness to violence against blacklegs, if not greater than miners of other races display, seems more terrible to the American imagination when they are called 'Huns' and speak a foreign language. Of course, with so many races

1 Virtue, op. cit. 750.

2Cf. the impressions of Mr. Spahr when he visited the Pennsylvania coal fields in 189s; America's Worting People (1900), 127-131. 
represented, the formation of strong unions is exceedingly difficult, and it is most surprising that so much success has already been achieved in the task of labour organisation. In many districts the unions are formed on the lines of language. Among the employees of a single company there will be found perhaps half a dozen branch unions composed of men belonging to as many nationalities; and proceedings at great mass meetings of strikers have often been carried on in as many as six languages-English, Magyar, Bohemian, Polish, Lithuanian, and Italian. ${ }^{1}$

So much, then, for the situation in general. And now we will begin with the organisation of labour and the machinery for wage adjustment in what is by far the most important branch of the industry-the bituminous. Here we have to realise what-after all we have said of the difficulties of the position-is really a most astounding fact, that in the four great states of Pennsylvania, Ohio, Indiana, and Inlinois, producing 62 per cent. of the total bituminous ontput, and emplo ing more than 125,000 men, there has been in existence for the last five years a system of 'joint agreement' which has so far worked quite satisfactorily on the whole and has altogether put an end to general strikes.

Observe the term 'joint agreement.' The equivalent English term 'collective bargaining' - which was probably first happened upon, and was certainly popularised, by the Webbs 2-has found a place in England in at least one formal agreement of the first

An interesting account is given in Lostie's Monthly for November 1900.

¿ Industrial Democracy (1897), pt. ii. ch. ii. 
inportance, the Terms of Settlement in the engineering dispute of 1898.' But it is not likely that the term will come into ceneral use in the United States; ${ }^{2}$ where the phrases 'joint agreement system' or (from the method of arriving at it) 'joint conference system in shortened forms the "agreement" or " conference system '-are alrearly coming to be widely employed. 'Joint arreenent' has the merit of being at once understood by the ordinary business man, who is arcustomed to use it in other connections; while 'collective bargaining' smacks of the econonists' lecture room and imposes the umrelcome strain of abstract thought."

Into the origin of the Joint Conference System in soft coal mining I have not time to enter at any length. It is sufficient to say that it was the outcome, early in 1898, of a general strike. Trade was improving after a period of depression, during which wages had fallen very low; and the leaders of the young and vigorous national miners' association, the United Mine Workers, seized the strategic moment to put forward their demands, both for an increased wage and for a method of joint conference which would dispense with Strikes for the future. ${ }^{4}$ Of course no such organisation springs at once fully armed from the brain of an industry; there has always been a long period of gestation; and

1 Text in Econ. Journal, viii. 118. See official note to $\$ 4$ (p. 120), 'Collective bargaining between the unions and the employers' associations is here made the subject of distinct agreement.'

'Cf. Professor Durand's observations in Teq. Ind. Com. xvii. pp. lxxvi-lxxviii.

3 The Final Report of the Royal Commission on Labour, 54, 116, speaks frequently of the agreements themselves as ' collective agreements.'

${ }^{4}$ I purposely omit the lesser causes of dispute-company stores, methods of sereening coal, period of payment, appointment of checkweighmen, \&e. \&c. 
in this case unionism had had a long and chequered history before the victory of 1898 . Indeed before then, for a period of eight years, from 1886 to 1894 , there had been a system of interstate agreement by representatives of the two parties meeting in annual convention. But the experiment failed from want of concert among the operators and of coercing power upon the side of the miners. The operators of Southern Illinois had never joined; those of Northern Illinois withdrew in 1S8s; those of Indiana in 1899; and the whole plan disappeared in that most disastrous of all situations-a strike against a falling market and against the desperate effort of every operator to save himself by cutting under his neighbours.' 1

The system since January 1898 has been as follows:

1. An 'Interstate Convention' (otherwise described as a 'Joint Convention' or 'Conference') of operators and miners from the four states of Pennsylvania, Ohio, Indiana, and Illinois, takes place early each year. A large number of delegates are present,-in 1901, 499 miners and 182 operators; but the negotiations are chiefly carried on by a Joint Scale Committee of thirtytwo persons, i.e. four members from each side from each state. The final decision of the precise rate to be paid for the ensuing year is usually referred by the Scale Committee to a sub-committee of sixteen. The Scale Committee reports to the Convention from time to time the progress which is being made; and after discussion in general conference-where also each side is allowed four votes for each state-the unsettled questions are referred back. When the Joint Scale

${ }^{1}$ This most significant bit of history is given by Mr. George in Q. Jour. of Economics, xii. 196-199. 
Committee makes its final report, it is usually adopted unanimously without change. ${ }^{1}$

It is to be noticed that there is here no element of arbitration, no judgment cutting the knot of a dispute by an outside Umpire, or Chairman with casting vote, as in England. It is a method of pure bargaining: and hitherto it has been required that all final votes, either of the Scale Committee or of the Convention, shall be unanimous.

At present while the miners at the convention are all the regularly appointed representatives of the society of United Mine Workers (who, indeed, have usually been engaged in holding their own annual convention before they are joined in joint convention by the operators), there is ' no such definite organisation of all the operators of the four central states; and the agreements are signed only by a few operators as the representatives of those present in the convention, but with no particular power to coerce such operators as refuse to be bound.'"

2. The general agreement, it will be readily understood, requires a good deal of detailed interpretation and expansion in its application to the several parts of the enormous area concelned. Accordingly there needs to be a whole network of local agreements. There is one for the Pittsburg district of Pemsylvania; ${ }^{3}$ as many as six or seven for Ohio (one particular area, the Hocking district, which produces one-third of the Ohio output, being what is called 'the basing district' 4 ), two for

1 Rep. Ind. Com. xvii. :327, from which also some sentences in the above account have been borrowed.

2 Ibid. xvii. 329. A specimen Interstate Agreement, that for 1900, will be found in the Appendix IV. 1.

3 That for 1901 is given in the Appendix IV. 5.

4 That for 1900 is given in the Appendix IV. 4. 
Indiana. ${ }^{1}$ In each case the miners at the conferences are the regular representatives of the district union, while ' in most instances there is no very formal organisation of the coal operators.' ${ }^{2}$ In Indiana there is provision for the arbitration of disputes in particular collieries by a small committee, two from each side, with an umpire, if need be, selected by the four; and, pending settlement, no stoppage is allowed.

In Illinois, however, there is a most elaborate system of state and district agreement which deserves careful attention, first becanse it applies to some 40,000 men in the state, and secondly because it indicates the ideal towards which the other states are working. ${ }^{3}$ To begin with, the coal operators are better organised than elsewhere, and the Illinois Coal Operators' Association is able to act on behalf of the whole body of coalowners in the state. Its members meet amually in joint convention the delegates of the miners (after the State Convention of the United Mine Workers); thus in 1901, 15.5 operators were present and $26 S$ miners' delegates. The procedure is the same as at the Interstate Convention; and the rates of wages to be paid in each of the nine districts, and in each of the several localities comprised in the districts, are arranged by a Scale Committee of two operators and two miners from each district, and, after discussion, accepted by both parties. The State Agreement begins by reciting the Interstate Agreement just made between the operators of the four states and the United Mine Workers at the Interstate Convention, fixing the pick-mining price of bituminous : mine-run coal at Danville, taken as 'the basic point' for

${ }^{1}$ One for bituminous and one for block coal. The bituminous agreement for 1900 is given in the Appendix IV. 3.

${ }^{2}$ Rep. Ind. Com. xvii. 332.

3 The text of the agreement for 1902 is given in the Appendix IV. 2. 
the state, and then proceeds to adjust all the other district rates in accordance therewith. 'Recognition' of the union could hardly be carried to a further point than it is in this agreement. Membership of the union is practically made compulsory, for its officials are treated throughout as the natural representatives of the men. In case of 'local trouble' at any shaft, there is provision for negotiation between the pit boss and the miners' local president and pit rommittee; in case of their disagreement, between the superintendent of the company and the president of the miners' local executive board, and so on, up to the highest state officials. Although it is not mentioned in the agreement, the Operators' Association employ a skilled expert, called their Commissioner, whose business it is to settle the most difficult cases in consultation with the State President of the United Mine Workers. ${ }^{1}$ So much are these two men trusted by the two parties (performing as they do in some measure the functions of the joint committees of Durham and Northumberland), that in the wage agreement itself the determination of the exact wage is, in some cases, either left to Commissioner Justi and President Russell, and ' then to become a part of this contract,' or to a small committee composed of these gentlemen and two or three from each side. Even more interesting is the readiness of the Illinois operators to trust to the sound sense of the President of the national union himself. In 1901 a most troublesome dispute arose in the Danville sub-district as to the timbering of the working places. It was finally decided at a joint meeting of the miners and operators of

1 It appears from the Report of the Fourth Interstate Convention (1901) 56, that there is a functionary bearing the same title in Indiana also. 
the sub-district to refer the matter to Mr. Mitchell, President of the United Mine Workers of America, and Mr. Justi, the Illinois Commissioner; and these, after visiting the mines, recommended a series of fairly precise rules, which were at once adopted. Remembering that, to many worthy persons in America, Mr. Mitchell is the typical firebrand, one rubs one's eyes with surprise when one learns that 'this decision in general favoured the contentions of the operators.'

But I want to further illustrate the close co-operation between the operators' association and miners' union arrived at in Illinois. The agreement of 1902 lays down that 'the right to hire and discharge, the management of the mine and the direction of the working force are vested exclusively in the operator, and the United Mine Workers of America shall not abridge this right,' and 'the operator's will recognise the pit committee in the discharge of its duties as herein specified, but not otherwise.' ${ }^{2}$ But the operators also 'agree to check off mion dues, assessments, and fines, from the miners and mine labourers, when desired, on proper individual or collertive continuous order, and furnish to the miners representative a statement showing separately the total amount of dues, assessments, and fines collected.' This, while it does not explicitly establish compulsory union membership, must necessarily-from the wholesale and rough-and-ready way in which such things have to be done-practically bring it about. ${ }^{3}$ On the other hand, it is agreed that

${ }^{1}$ Rep. Ind. Com. xvii. 335.

$=\$ 13(f)$ and $\$ 17$ of the Illinois Agreement, given in Appendix IV. 2.

3 What is called 'the eleck-off system' is formally recognised by the Indianu Agreement, $\S 17$, and by the Agreements of the several districts of Ohio. The text is given in Appendix IV. 3 and 4. The leaders of the United Mine Workers have, I believe, hitherto endeavoured in vain to get 
work shall never be suspended while a complaint is being investigated, and ' if any day man refuse to continue at work berause of a grievance. . and such action shall seem likely to impede the operation of the mine, the pit committee shall immediately furnish a man to take such vacant place at the scale rate, in order that the mine shall continue at work; and it shall be the duty of any nember of the United Mine Workers, who may be called upon by the pit boss or

'the check-off systcm' made part of the Interstate Agreement. It is said that 'dues are checked off for the organisation in every field except the Pittsburg district,' and in Indiana and Ohio this has been the practice 'for more than ten years' (Report of the Fourth Interstate Convention, 105, 114, 166). The discussion upon the subject in the Joint Scale Committee at the fourth Convention will be found of extreme interest. The miners' leader's urged (1) that they could not enforce the rates agreed upon unless all the miners belonged to the mion; as Mr. Mitchell put it, ' as long as our organisation is held responsible for the observance of every agrecment that we enter into, that every man that is employed by your companies should hold allegiance to the organisation.' Another miners' representative frankly represented that. now the operators had recognised the United Mine Workers 'as a business institution,' they' 'should go one step farther and help us to compel the rebellious of our own ranks to be parties to the compact.' The leaders argued also (2) that the larger their funds were, the better able the would be to coerce the operators of West Virginia in the way desired by the operators at the Interstate Convention. Mr. Robbins, representing the Pittsburg operators, replied that to check off union dues would lead to legal difficulties, and that so many of the Pittsburg miners were outside the union that it would be improper for the operators to 'take sides.' 'It is folly to talk of putting other things into this agreement, which is hard enough as it is. As to the facts. We have checked off a checkrreighman's fund throughout the entire district, because the checking off of a checkweighman fund is legal and is authorised by the laws of our state. We have offered, further than that, to check off the expenses of delegates to their state conventions, district conventions, national conventions, and interstate conferences. We have refused, and by the advice of onl attorneys do refuse, to agree to check off a fund that will put us into the conrts, and we are not going to put ourselves in that position. We have a district that is partly organised and largely unorganised, and it would immediately make a conflict between organised and morganised men in the Pittsburg district, where we would be taking sides where I say we have no business to be taking parts' (Report, 106). 
pit committee, to immediately take the place assigned to him.' ${ }^{2}$ Above all, 'the operators are hereby guaranteed the hearty support and co-operation of the United Mine Workers of America in disciplining any miner who from ignorance or carelessness or other cause fails to properly mine, shoot, and load his coal.'

Now why this conversion of the great body of the bituminous operators to systematic co-operation with the union? Simply because they were tired of the reckless competition that had previously prevailed, and saw in the mion the only means of obtaining uniformity, at any rate in the cost of their labour. To be relieved from the necessity of perpetually watching their competitors to see whether they were getting their labour more cheaply and, if they were, of forcing lower rates on their own men in the face of continual ill feeling, if not of actual strikes, would be worth some little possible sacrifice in the matter of profit. The depression of 1593 had broken down the old agreements and turned every operator's hand against his neighbour; and now that trade was reviving, the coal of West Virginia, mined by cheap and unorganised negro labour, was pushing its way into the western markets, in competition with Pennsylvania and Ohio, and the coal of Southern Illinois was beginning to compete with that of Northern Illinois in the Chicago market. ${ }^{3}$ It was the feeling that it was only the action of the men which could set limits to a competition which most operators hated even while they felt driven to it, which caused so many of the operators themselves to sympathise with the strike of 1897 . The Pittsburg operators had lately

1 Illinois Agreement, $\$ 13(b)$ and $(c)$ $\because$ Ibid. $\$ 5(b)$.

' George, Q. Jour. of Economics, xii. 193-194. 
endeavoured, without the aid of their men, to carry through a so-called ' uniformity scheme,' but had failed to secure the adhesion of the 9.j per cent. of the operators which was deemed necessary." The men on their side recognised that the 'large majority of employers' were 'not responsible for the conditions'-the low wages-which they found fault with. They were 'due,' they said, "to the actions of a few who have cut prices far below the demands of the market, thus demoralising the trade and cutting wages indiscriminately."

When, therefore, the operators had accepted the joint agreement plan, it at once became their interest that the union should be strong. Like the Scotch coalowners before referred to, they urged upon the miners' leaders the necessity of extending their organisation ${ }^{3}$ and the majority of them have since watched with 'equanimity the various strikes, some of them serious, which have taken place: for most of these strikes have been necessary to coerce the operators in particular districts who refused to abide by the general agreement. Indeed the operators rely on the miners to enforce the joint agreement by threat of strike; and the Report of the Industrial Commission ${ }^{4}$ grimly records the advance towards a common rule in the words: "As a general thing the United Mine Workers have been sufficiently strong to bring the rperators into line.'

We are now in a position to realise the full signifi-

1 George, Q. Jour. of Economics, xii. 204.

2 Itide. 191.

3 "That the agreements arrived at in the joint convention (of 1898) might be as far-reaching as possible, it was unanimonsly voted that the miners' national officials begin a campaign of organisation in all states where the miners were poorly organised, such as West Virginia, Kentucky, Alabama, and Iowa.-George in Q. Jour. of Economics, xii. 457. Mr. George quotes also the Black Diamond (the journal of the operators): 'to this the operators pledged their hearty support.'

xrii. 329. 
cance of the Interstate Convention. I have avoided hitherto using the terms generally given to the area covered by its agreement. It is ' the competitive field,' 'the competitive district,' 'the central competitive field,' 'the competitive coal fields.' All these indicate that the prime purpose of the agreement is to establish a substantial uniformity of labour-cost over all the states whose product appears in the same markets. It establishes this uniformity for an output which is about as large as that of the English fields of Yorkshire, Lancashire and Cheshire, and the Nidlands; so that the 'competitive coal fields' of America may be fairly compared with the 'Federated Districts of England.' In both countries the purpose is the same-to eliminate labour-cost differences from market competition; or, in other words, to lift competition on to a level plain of labour-cost. ${ }^{1}$

In each country the desirability of extending the mechanism to outside districts largely turns upon a question of fact-do the outside districts compete in the same market? In America it is allowed by all parties that this is the case with West Virginia in relation to what, to avoid ambiguity, I shall speak of as the 'central competitive area.' It is sufficient to look at the map to see that the coal tracts of West Virginia are simply an extension of those of Pennsylvania; and now that they are being opened up by large capitalists with the aid of cheap negro labour (employed, many of

1 As against the principle of uniformity, the operators at the conventions have sometimes invoked the principle of paying men what they are 'worth.' But by ' worth' they have apparently sometimes meant individual strength and capacity, sometimes market value as determined for the time being by the demand and supply of labour in a particular. locality. The recognition of 'worth,' however, in this latter sense might go far to destroy the whole agreement. See the discussion in Report of the Fifth Interstate Convention, 106-108. 
them, by white miners on a plan of sub-contract), they are a perpetual menace to the stability of conditions in the whole of the rentral area. Hence both parties are anxious that the orwanisation of the United Mine Workers should be extended to this district; and some of the operators at the joint convention are inclined to blame the union for having "failed to fulfil their earlier promise that they would increase their strength in West Tirginia and force the operators of that state to make terms, and come into the interstate agreement.' It would seem that up to the present the efforts of the union have met with only slight success; and, unless they make more rapid progress, West Virginia will constitute a serious source of danger to the joint agreement when depression in the coal trade again becomes acute. ${ }^{1}$

About other states there is not the same unanimity. The United Mine Workers have added enormously to their numbers in many other states: and joint state or district conferences have succeeded in drawing up agreements in Kentucky, Tennessee, and Alabama, in Iowa and Misomri. Kansits and Michigan. The question now is, shall any or all of these states be admitted to the Interstate Convention? The miners are in favour of it; the operators have litherto opposed it. Michigan has been repeatedly discussed; but the arucial anse is that of lowa, which now produces some four or five

1 An account of the discussions on this point up to 1900 will be found in the lieport of the Industrial Commission, xvii. 329. The subject occupies a large space in the Reports of the Fourth and F'ifth Interstate Conventions (1901 and 1902). The representatives of the operators have usually alleged the competition of West Virginia as a reason for lowering the rate; while the representatives of the miners have replied that it is the Pennsylvania operators taking part in the convention who have invested in West Virginia and are responsible for its competition, and that the United Mine Workers have already succeeded in serewing up wages a little in one or two districts of that state. (See Note below, p. 111.) 
million tons annually. The miner's allege that Iowa is 'as directly a competitor with Illinois and other states in the present system as West Virginia ; while the operators leclare that the conditions in Iowa are already 'fair' enough, and that there is 'no excessive competition' with the central area. Moreover, the admission of Iowa and other states would, the operators declare, make the Convention unworkable. The operators of the four states now included are sufficiently acquainted with the conditions of the whole area at present dealt with; they have not a like knowledge of Iowa. And it is difficult enough as it is to get unanimous consent of all the delegates: it would become impossible if there were more states to harmonise. Let a new group of states be formed west of the Mississippi with its own Interstate Convention and Iowa as its nucleus. To which an Iowa operator replied, that any new groups that might be formed "would still compete with one another and with the central field, and that some form of agreement between all fields would be desirable.' If such intergroup competition cloes make its appearance, the policy which has led to the present system will doubtless dictate its enlargement by the establishment of some sort of supreme Coal Congress. It may be conjectured that the representatives of the two parties will by that time have a somewhat freer hand, and will not be expected to carry with them the acquiescence of two large assemblies. ${ }^{1}$

1 The quotations in the last paragraph are drawn from the Report of the Industrial Commission, xvii. 328. In the Fourth Interstate Convention, 1901 (Report 174), the objections of the operators were thus summed up by Mr. Robbins, the most prominent of their representatives: "This Interstate movement, with its rules and its peculiar organisation, is different from anything that exists in this or any other country. It is a movement that is full of pitfalls. It is one where a very small minority can block the entire proceedings of the majority and prevent a settlement. 
What is coming to be known as the 'regulation' of an industry may, however, be aimed at from more than one direction. Uniformity of labour-cost will remove one of the chief causes of differences in selling price; on the other hand, miformity of prices will diminish the temptation to cut down the labour bill. A main cause for the general strike of the miners in 1897 was the almost complete absence of combination among the bituminous owners, and the repeated failure of selling agreements. But there are indications that this state of things is passing away. The present anti-trust law puts formidable obstacles in the way of pooling or other similar combinations of producers, so long as each retains his legal independence; for that very reason, as the economic forces pushing men towards common action do not cease their pressure, the law has the unintended effect of encouraging complete amalgamation,-which of course no statute can prevent. And so in Pennsyl-

. . That rule was adopted for protection on both sides. It was adopted as a mutnal protection. To increase the possibilities of disagrcement and failure is against the interests of the movement. It is against the interests of the movement for the miners as well as for the operators. The movement has been successful now since it was started last in Chicago. We lrave come together now in these four cities and have made agrecments, and I tell you to let well enough alone. There is no reason why the states of Iowa and Michigan should be selected out. You can just as well select ont other states. Kentucky and Alabama are just as competitive and more competitive than the states of Michigan and Iowa.' The advocates of the inclusion of Iowa had maintained that that state and Michigan were more closely eonnected with the states represcnted than the others named: "If you form other conferences, if you form a conference south of the Ohio river, another one west of the Mississippi, have three conferences as was suggested last year in Indianapolis, then I say that Iowa and Michigan belong to this conference nevertheless. We compete with Missouri coal just a little, we compete with Kansas coal just a little; but we compete with Illinois and Ohio and the block coal of Indiana in all of our markets' (ibid.49). All this is denied by the operators (ibid. 46). It should not be inmpossible to obtain a trustworthy report on the facts of the case which would be authoritative with both parties. 
vania in 1899 an amalgamation was effected of all the 140 bituminous properties accessible to railways, in the Pittsburg coal district. 'This is the Pittsbury Coal Company, with 32 million dollars in 7 per cent. cumulative preferred stock, and a like amount of common stock, the greater part of which was thrown in as a bonus to subscribers in the hope that it might earn something some day. Side by side with this was created the Mononyahela River Coal Company, with a nominal capital of 30 million dollars (one-third bonds, one-third preferred stock, one-third common), dealing with all the coal of the state sent down the Ohio and Mississippi. These two great companies began with a mutual understanding, and they are now under one control. Together they form the largest single coal business in the world, with a considerable railroad mileage not only in Pennsylvania, but also at the western end of Lake Superior. To the great lakes it sends some six million tons annually, and it owns docks at various lake ports. Such a combination evidently makes it much more feasible to maintain a steady price, and therefore a steady wage rate, in Pennsylvania. Of course it strengthens the coal-owning interest in its negotiation with the miners. But the New York banker who financed this amalgamation declared before the Industrial Commission that he 'found that the leaders of labour organisations were fully alive to the advantages of dealing with one concern, rather than with a hundred and forty. So far as the company was concerned, instead of being indisposed to deal with the representatives of organised labour, they were 'doing it all the time and preferred to do it.' The arrangement with the United Mine Workers was entirely satisfactory, and

1 Not including the coking coal. 
there was not the slightest friction. The labourer, he went on to say, has as much right to combine as they had to combine these properties, and a right to be represented by the organisation. A manager who wouldn't listen to such representatives 'ought to seek other employment.' 'If I owned the property, he would:'

A close combination among all the bituminous operators for the purpose of controlling prices is probably not for the present a matter of practical politics, though to this I shall recur. But something like this, in close confederacy with an equally complete combination of the miners, is the ultimate ideal of the leaders of the United Mine Workers. They do not like to be called 'a trust,' but what they do believe, as they expressed it before the Industrial Commission, is that 'the best interests of the coal trade would be served' by 'a general union' or 'association' of both miner's and operators, "treating mutually and voluntarily together, and holding selling prices up to reasmable rates."

${ }^{1}$ Rep. Ind. Com. xiii. 101-102. Cf. xix. 230. For a list of ten other large consolidations in 1899-1902 among soft coal operators, see Mineral Resorres of the United States, 1901 (U.S. Geological Survey), 280.

${ }^{2}$ Rep.Ind. Com. xii. 63. Something may be added here as to the considerations which are urged in the American Interstate Conventions with regard to the causes which onght to influence wages. Unfortunately it is not possible to institute a comparison with discussions in England because the final negotiation in America takes place in a Sub-scalecommittee, whose proceedings are not reported. In the Convention and in the Scale Committee most stress is laid upon prices. But the leader of the operators, Mr. Robbins, of the Pittsburg Coal Company, has also done what in Great Britain it has usually been left for the miners to docalled attention to the matter of volume of trade: "It is not a question of price that governs alone; it is a question of volune of business; that is as necessary as price.'-Rep. Fourth Convention, 55. The operators also have urged that an alleged increase in the cost of mining should be talsen into account (i己id. 157). On their side the miners have pointed to an alleged increase in the cost of living as justifying a rise in wages (itid. 69), and have disclaimed any intention to rely upon their "great 
$-450.940$

$=$ 
strength '(Rep. Fifth Convention,52). As to what the prices are or have been, neither party has been inclined to accept the figures produeed by the others. The miners have quoted " the journals published in the interests of the operators' (Rep. Fourth Convention, 70); the 'Government coal reports' (Rep. Fifth Convention, 42), and especially the Reports of the Illinois Bureau of Statistics (ibid. 63). As to the latter one operator declared that "the operator's do not give the state statistieian the figures as to cost of production or selling price. It is none of the state statistician's business, and we won't give him the information.' Accordingly ' the Coal Pieports of Illinois are all buncombe and rot' (ibid. 78). Mr. Pobbins, on behalf of the operators, offered in 1902 to substantiate his facts by a referenee to his books (ibid. 74). The American 'scale' (which is simply a rate and not a sliding seale) fixes wages for a year; and Mr. Robbins went on to propose that the realised prices of one year should determine the wages of the next: "To show our good faith in the matter we made the proposition that a scale should be established based upon what our books would show as to the relative difference in the selling prices of coal in the year 1901 and the year 1900, and if the records would show that there was an increased price, a relative increase in the price of mining would be paid; and if it shows a decreased selling price a relative decrease in the price of mining would be paid, (ibid. 122). Whether this has led to anything like the British system of accountants' 'ascertaimments,' I do not know.

[Additional Note to Lecture V.-It appears that while the great strike in the anthracitc region (described in the next Lecture) was proceeding in Eastern Pennsylvania, a severe strike was also being engaged in, for sereral months, in Wcst Virginia, in consequence of the refusal of the operators to 'sign a seale' laid before them by the U.M.IV. of $A$. The strike was only very partially successful; but the miners were granted an inerease of 10 per cent. in wages in certain districts; and, in one important district, that of Kanawha, where some 7,000 men were employed, an agreement was finally reached with the operators, recognising the right of the men to combine. This the U.M.W. regard as 'establishing for the first tine the moleus of an organisation in West Virginia.' An account of these transactions. from their point of view, is given in the Minutes of the Fourteenth Annual Convention (1903), 38, $52-54.7$ 


\section{LECTURE VI}

\section{THE ANTHRACITE PROBLEM}

I propose, in this lecture, to concentrate your attention upon the anthracite or hard coal industrythe coal-mining of Eastern Pennsylvania; and this not only because of the recent strike. That strike, indeed, has been one of the most significant in the history of industry. It is, I think, only the third occasion in modern times that an almost complete cessation has taken place (outside Russia or India) in the supply of a necessary of life for several millions of people. The only parallels that occur to one are the potato famine in 1845 and the cotton famine in Lancashire during the American Ciril War. The recent coal famine in America was likewise the result of war-of civil indus. trial war-and of civil industrial war in the country itself that suffered. It is the first time that 'organised labour' has actually succeeded in enforcing an embargo on a necessary article of consumption long enough to secure its purposes.

And, as a consequence of this, it is the first time the chief Executive Magistrate of the United States has intervened and compelled the parties to the dispute to refer their contention to a tribunal appointed by himself. It was an important step when, in 1894, the President of the United States appointed a Commission to report on the great Chicago railroad strike. But by that time the strike was practically over, and the report 
of the Commission had no share in determining the issue: but now both parties have been compelled to resume work while the case is being heard by a Commission whose judgment they will be compelled by public opinion to obey. Just what the nature of the pressure may have been which President Roosevelt brought to bear upon Mr. Morgan, and through him upon the coal operators, we shall have to wait a few years before we learn. Nor, indeed, does it much matter ; there are more than one means of coercion in the hands of the executive government of a great state. And it does not matter what the motives were which influenced the President. I have equally intelligent American friends who believe, some of them, that it was sheer humanity which impelled him to intervene, and, some of them, that it was a deplorable regard for the electoral interests of his political party. In either case, the step has been taken and the precedent has been created. If it has an effect only as great as its nearest parallel-the intervention of the English Gorermment in the midland coal strike of 1892-and opens a new period in the relations between mining labour and mining capital, in the same way as the creation of the Board for the Federated Districts has done in England, it will have left its mark on history.

I ask your attention, howerer, to the subject, for other reasons: because it sets before us, not the labour. problem only, but a whole series of typical problems of modern industrial life in general and of American industry in particular; and, above all, because it illustrates the necessary approximation in our time of the two problems of the combination of labour and the combination of capital.

You will remember that the anthracite of the 
United States is practically all found in Eastern Pennsylvania, separated by some two hundred miles of mountainous country from the Pitsburg soft coal in Westem Pemsylvania. In appears in a number of narrow bands or strips of land: the northermost (or Wyoming) field being 50 miles long, and in its widest part $5 \frac{1}{2}$ miles across; the southernmost (or Schuylkill) 55 miles long, and in its widest part 4 miles across, but much of it very narrow. ${ }^{1}$ The eastern middle (or Lehigh) field and the western middle are smaller, in proportions which the eye may easily gauge on the accompanying map. The total coal area is $483 \mathrm{sq}$. miles. The number of persons employed in 1900 was 143,831.2 This is not far short of the total number employed in the 'competitive bituminous fields' under 'the joint agreement, althongh the tomnage raised, some $47 \mathrm{mil}$ lions, is very much less-little more than half." The number of men is somewhat smaller than in our Great Northern or South Wales fields. This will give some impression of the masnitude of the problen.

Let us begin by observing that in the anthracite coal fields an element makes its appearance as of primary importance which is hardly present at all as a determining factor in the bitmminous fields; and that is the element of transportation, or, as we call it in England, transport. Coal mining is not only dependent on the railway companies for the carriage of the coal: the railroads themselves now own by far the greater part of the coal-bearing land in the district. The accompanying map indicates the ownership of anthracite coal lands in 1896 ; the absolutely black patches

1 Roberts, The Anthracite Conl Industry, 5. See Map IV. opposite p. 126.

2 Bulletin 43 of the Department of Labor, 1194.

s Cf. McLeod in Rep. Ind. Com. ix. 567. 
representing the properties, in that year, of what are known as the 'independent operators.' In that year the independent output was estimated at some 34 per cent. of the whole; by 1901 it has fallen to 29 per cent. ; ${ }^{1}$ it is now probably a good deal less. ${ }^{2}$ There could scarcely be a better example of the way in which absolutely free competition works towards its own destruction. Two out of the eight railways concerned were, indeed, engaged in mining from the time they reached the district; but most of them, on the contrary, only entered into the mining business to secure their freight tonnage from competition. Thus, the largest owner of coal-land at the present time is the Philadelphia and Reading Railway (known for short as the "Reading"). This railway down to 1871 did not own a yard of coal-land. It had enjoyed up to that time, however, a practical monopoly of the traffic from the southern anthracite field; but in that year two much greater railroarls, the Pennsylrania on the west and the Lehigh Valley on the east, began to enter its territory and compete with it for the carriage of coal. ${ }^{3}$ The Reading company believed, and doubtless with reason, that it must, at almost any cost, "assure the permanence of its tommage; ' and for this purpose it began to buy up coal-land right and left. Other railway companies have done the same for the same reason. They are no longer allowed by law to operate their coal mines directly; they all make use of subsidiary companies (corporations) for the purpose, sometimes bearing a similar name-thus the Philadelphia and Reading Rail-

${ }^{1}$ Rep. Ind.Com. ix. 535.

${ }^{2}$ Roberts (August 1901), 66, raakes it 20.99 per cent.

3 The situation will be at once apparent on examination of the accompanying Map III. opposite p. 124. 
load Co. works through the Philadelphia and Reading Coal Co.; sometimes bearing a quite different name -thus the Pennsylvania Railroad works through the Scranton Coal Co. But, having become coal operators mainly in self-rlefence against other railroads, they are exceedingly formiclable competitors for the independent operators. The independent operators are dependent mpon them for the carriage of their eoal; and they ran charge what rates they please for the service. As to whether the rates have often been excessive in themselves there is a good deal of controversy. They are. muloubtedly, much higher than those which the same companies charge for carrying soft coal; but for various reasons the hanling and unloading of soft coal are really less expensive. ' Certainly there has frequently been a wideypread and intense feeling among the independent coalowners that they were being penalised by the rates charged. It was no reply that the railroads charged themselves (i.e. the subsidiary mining companies practically identical with themselves) the same rates as they charged every one else. For to them it was but transferring the money from one pocket to another. And the feeling among the independent operators has been such that they have again and again tried to get railroads of their own. One or two of the biggest coal companies have constructed little lines from their own mines to some one or more of the great competing roads. ${ }^{2}$ But the proposal which has frequently been mooted in one or other district to construct, in the interest of the small operators, a new railroad all the way to tide water has invariably broken down. The railroads, threatened by

${ }^{1}$ Rep. Ind.Com. ix., Digest xxvii.; Bulletin 43 of Dep. Labour, 1163.

* E.g. Coxe Bros. \& Co, a road of 40 miles, Rep. Ind. Com. ix. 590. 
a new rival, invariably offer good terms to a sufficient number of those independent mine owners who have pledged tonnage to the new line to induce them to part with their property, and so once more to exorcise the danger even at a heavy cost. ${ }^{1}$

It must not, indeed, be supposed that the predominance of the railroads has been due simply to their powers as carriers. It has been caused quite as much by their greater command of capital. Nining, as first carried on in these parts, required very little capital. The operators worked at the outcrops; they took what they could get easily and cheaply; and then many of them left the workings, uncharted and uncared for, to be a source of danger to future generations. As deeper shafts have become necessary and more capital has been called for-both to meet the greater cost of successful mining and the greater financial risk involved in seeking the coal ${ }^{2}$ - the larger ('apitalists (mainly the railways) have been able to buy up the small holdings, and have justified their presence by developing resources which would otherwise have remained unutilised. ${ }^{3}$ Not that railways lave been alone in taking advantage of the situation: there have grown up two or three other great coal-mining companies which have owned but little railroad: ${ }^{4}$ and there is everywhere a tendency towards the absorption of the smaller in the larger concerns.

The combination of mining with railroading has one minor consequence which is worth noting. It makes it very difficult, if not impossible, to disentangle

${ }^{1}$ Rep. Ind. Com. ix., Digest xxvi.

2 MeLeod, in Rep. Ind. Com. ix. 570.

${ }^{3}$ De Rousiers, Les Industries Monopolisées aux États-Unis (1898), 100-103. Roberts, 19.

4 E.g. Coxe \& Co. and the Pennsylvania Coal Company. 
the accounts of the two businesses. And when the miners emploped by the railroads refuste to believe what the officials tell them of the small or non-existent profits of the mining business, and declare their conviction that the railroads are making lare profits as carries's of coal, they are simply echoing what the independent operators are always saying. There may be an answer (o) this: it maty be true, as the president of the Reading Company avers, that neither the carrying nor the mining branch has paid any profits for geats on a perfecty genuine and unwatered stock.' Still. some of the roads have muloulstedly at times obtained larese profits on their carring business; and anyway the situation is such that no very convincing fintmeial statement seems arailable."

This, then. is the first point : practicatly all the coal is carried. and more than three-quarters of it is mined, by eight great railwa! companien. Hitherto the demand foom the Whet and South has been comparatively small-perhaps one-fifth of the whole. All the rest is comsumed in the eastern states, from l'enusyrania northward ; and a rery large part of it is campel to tide-water, as it is called, at New York and Philadelphia, to be thence distributed.' The carying roads have consequently been driven for many years past into the fiercest competition, a competition which has exhibited on an increasingly large scale all the phenomena which we have now learnt to expect. The inevitable result has

${ }^{1}$ Bulletin 4 s̈ of Lab. Dep. 1160; Rep. Ind. Com. ix. 566.

2 Roberts, Anthracite Indwstry, 75 ; Virtue, in Quarterly Journal of Economics, x. 321 (April 1896).

${ }^{3}$ See the evidence before the Industrial Commission (Report. ix. 474) of Mr. Grcene, the well-known authority on 'Corporation Finance.' Cf. the observations in Final Report of Ind. Com. xix. 448.

${ }^{4}$ Rep. Ind. Com. ix. 562. 
been the repeated attempt. Anring the last thirty rears, to moderate the competition by some measure of combination. sereral plans have been resolted to: an acreed schedule of tide-water pricts-iel. priecs at competitive points: a definite dirision on allotment of tidewater tommage: an allotment of permissible ontput : a curtiliment of total output by gentral stoppages. Bu until recently each has hoken down after about a years trial. Iesperation drove the road into one compant after another. Lut the mentories of business men ale surprisingly short and after a few monthe of companat tive punperity. the members of the combination simply broke awa from their agreements. They could not control their selling antent- - all anxions to ilo as large a trate as they combl posibly get hold of : and each distrusted the wher. and believed the other was plitying fast and lowe with ile agreement. These plain men of common-else hatre expended an amomnt of casuistry

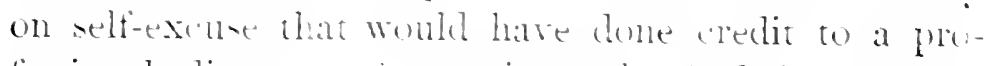
fessional direcon of comeciences. And it must be confessed that. eren it all the participants in the

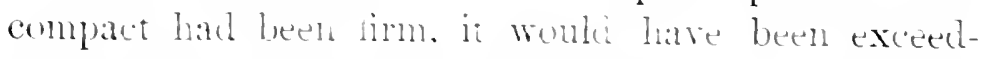

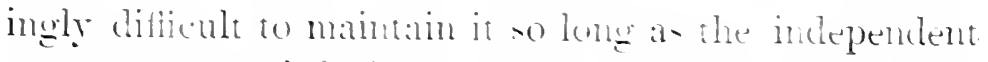
operater were left free ont-icle -imcluching some quite large comerers: and while one great railway company,

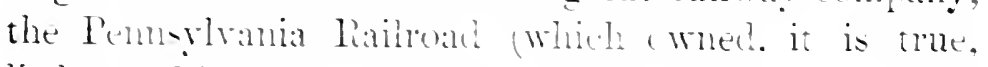

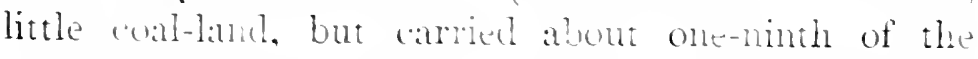

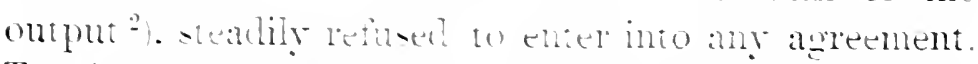

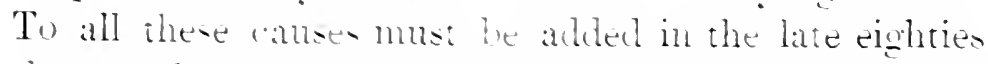
the popular omtery anainot monopolies. and the rarious

The whole history of the mater is clearly set forth $i y$ Mr. Virtue in the Quarterly Jomal of Economic's for April 189 (x. 290 sequ.

In 1900. Fis. Ind. Cim. xix. 44 . 
legislative measures prohibiting combination in restraint of trade.

of all the railroad companies it seems to be generally agreed that it was only the Reading which was never guilty of breach of faith. The Reading is nothing but a local Eastem Pennsylvanian line, withont any of the through traffic of some of its rivals; it is dependent almost entirely upon its carriage of anthracite, and therefore impelled to get control of as much of it as it can; and it has for some time owned much the larger part of the sonthern or Schuylkill field. It has always been the comprany which has felt competition most keenly, and whose financial position has been most perilous. Twice it has been bankrupt, in 1880 and 1884, after "periods of free competition.' Under these circumstances its anxiety for combination is easily explicable, and its faithfulness to its word certainly admirable. Tou may be surprised, perhaps, at its cheerful re-emergence after each bankluptcy. Time was that when the profits were ont the business would die; but with our modern fixed or specialised capital we have changed all that. A bankrupt business goes into the hancls of a receiver ; it is 'reorganised,' relieved of some of its debt, and once more enters into the fray, competing on equal terms with companies which are trying to meet all their obligations.

In 1892 the Reading had for its president a real general of commerce, a certain Mr. McLeod; and Mr. McLeod devised a new method of controlling the situation, which only failed owing to a quite unforeseeable concurrence of circumstances, and which anticipated the successful effort of more recent years. He realised that it was impossible to enforce a mere

${ }^{\prime}$ Roberts, Anthracite Indusiry, 310. 
agreement among roads remaining legally independent; and he hit upon the policy of 'consolidation by lease.' The two nearest rivals to the Reading road (as the map shows)-putting on one side the always impracticable Pennsylvania Railway - are the Central Railroad of New Jersey and the Lehigh Valley Railroad. Early in January 1903 President McLeod, having won over the two other directorates, brought about a lease of these two roads to the Reading, ${ }^{1}$ and so secured the direct control of almost 4 per cent. of the total quantity of coal carried. The actual shipments had been about 21.47 per cent. by the Reading, 11.51 by the Central of New Jersey, and 1.j.81 by the Lehigh Valley." The combination now also commanded, besides access to Philadelphia, two alternative routes to New York, and a route also to the Great Lakes. The only very powerful rival remaining outside was the Lackawamna road, which carried some 13.16 per cent. of the total shipment; but, as will be seen from the map, this tapped only the northern field. It was either not worth while or impracticable to lease, or be leased by, this road; but the acceptance of a common policy by this road also was insured by large purchases of stock by Lackawanna and New Jersey directors in one arother's railways, and their appointment on one another's boards. And now there were the independent operators to be brought into line. It had long been the practice of some of the roads to buy coal from independent operators along their lines, paying them 55 per cent. of what the coal fetched at tide-water. Mr. McLeod now offered them 60 per cent. if they

1 This was the practical result of the arrangement, which legally was rather more complicated (Rep. Ind. Com. xix. 455).

${ }^{2}$ Figures of 1895 in Roberts, Anthracite Industry, 74. 
would sign contracts for longer periods, seven or eight year's. ${ }^{1}$ Most of them were glad enough to accept these terns; but some, it is sair, had to be convinced by an advance in freight rates.2 So now some 70 or so per cent. of the whole business was gathered into one set of liands.

But Mr. McLeod looked beyond the anthracite field itself. 'My idea,' he aftermards told the Industrial Commission, "was to benefit the consumel' as well as the corporations I represented by bringing every interest, so far as possible, into one hammious oryanisutim." ${ }^{3}$ He proposed to do something towards eliminating that unnecessary, or, at any rate, too abundant middleman, the coal dealer, by erecting large 'pocket depôts' in certain places in the city of New York and other large cities, and expected to save the family consumer some 75 cents (3s.) a ton by the new plan. Noreover, to steady the trade, to counteract in part its seasonal character and enable the mines to be worked more regularly - a great boon to the men, by the way-he built two large storage bins near the Reading mines, where during the dull months of spring and summer he could house 300,000 tous of coal. ${ }^{ \pm}$

This masterly conception was too vast for a company to successfully carry out which enjoyed only the very mediocre financial reputation of the Reading. The Reading had to borrow eight million dollars; and, before the money came in, the financial crisis of the summer of 1893 began to cast its shadow before, and the money market became too tight for the operation. It is true there had been a good deal of public outcry when coal

'Rep. Ind. Com xix. 456 ; ix. 563.

"Virtue, Q. Jour. of Econ. x. 306.

${ }^{3}$ Rep. Ind. Com. ix. 568.

Ibid. ix. 564. 
prices had gone up and Congress had appointed a committee of inquiry. It is true also that the lease of the Central of New Jersey was of doubtful validity, and it was being attacked in the courts. ${ }^{1}$ It seems, moreover, that the attempt of the Reading to secure the control of one of the great New England roads, the Boston and Maine system, in order to get a market for its coal in the cities of Massachusetts and Maine, aroused the hostility of the financial interests associated with other railways." But it is probable that the stringency of the loan market would have been sufficiently hampering, without these additional causes, to wreck the scheme. And so far was the Reading from carrying out its projects, that it once more became bankrupt itself, and passed into the hands of a receiver.

Then the same old story was repeated. Each company, in desperation, lowered its prices, driven by the competition especially of the unfortunate Readingwhich no longer, while bankrupt and before reorganisation, was under the necessity of earning interest on its obligations. ${ }^{3}$ The year 1895 marked the lowest point reached by prices; and then the task of restoring 'harmony' was again undertaken. As the tide of prosperity began to return, the intensity of the struggle for existence diminished; until finally, in the years 1900-1901, when the tide reached high water, a practical consolidation has been actually, and, so far as we can see, permanently effected of a sufficiently large proportion of the coal interest to control the whole situation. In this last act of the drama Mr. Pierpoint Morgan takes the part as protagonist, but this time with success, which Mr. McLeod had tried to fill in the

1 McLeod in Kep. Ind. Com. ix. 572. Cf. Virtue, Q.J.E. x. 316 n.

2 Rep. Ind. Com. xix. 456. 3 Virtue, in Q.J.E. x. 317. 
preceding act-takes it at any rate in the public eye. It is common now to speak of 'the Morgan interests' in the anthracite coal business. ' How much has been due to Mr. Morgan's personal initiative, we must wait some time before we find out. Meanwhile, what we do know is that some very large financial operations, much bigger than these which broke down Mr. McLeod in 1893, have been successfully carried through-for a very substantial reward if the arrangement proves profitable-by the banking house of Messrs. J. P. Morgan \& Co., and that last year Mr. Morgan was in such a position that he could compel all the coal interests to accept President Roosevelt's proposal which they had just before positively declined. Without, however, seeking to determine who the strategists actually were, or troubling about the details of the several arrangements, it will be enongh for our purpose to observe the general nature of the new disposition of forces.

In the first place, it has been found possible at last to effect the railroad consolidation which the Reading has long set its heart upon-that between the Reading and the Central of New Jersey. ${ }^{2}$ This was effected by the purchase by the Reading of a majority of the Central's shares. This not only ended a most disturbing rivalry, and enabled the Reading to send its coal direct to New York, instead of by the expensive roundabout route vîे Philadelphia; it also brought under the Reading's management the coal-lands of the New Jersey Central. These lie mainly in the southern field, which is much further from exhaustion than the northern field; and by their acquisition the Reading is able to boast that it 'now owns and controls 


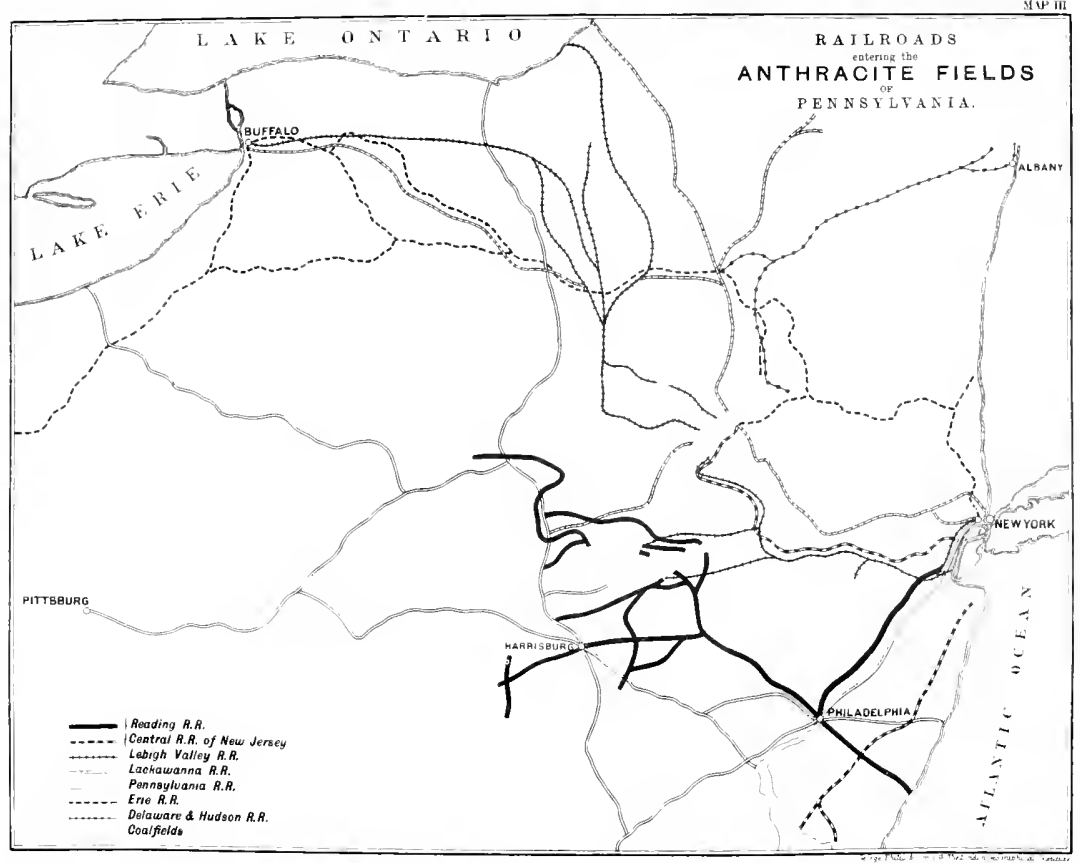


about 63 per cent. of all the unmined anthracite coal in the state of Pennsylvania. ${ }^{1}$

But the significance of this is for the future to see; and if the reserves of other fields are smaller, their operators are still in the field of competition. Accordingly it is thought advisable to take measures for the removal or the control of the individual operator: and that is the second feature in the process of consolidation. The largest single operator remaining, other than the great railroads, was the Pennsylvania Coal Company in the northern field, whose output was about 5 per cent. of the whole. Its shares have now been bought up by Morgan's, and sold to the Erie Railroad. ${ }^{2}$ The Erie has incurred a heary debt for then ; but it has tried to safeguard itself by establishing a sinking fund of 10 cents per ton, which, it is calculated, will about suffice to extinguish the debt by the time the coal is exhausted (i.e. in this case, some fifty years hence). This is a good example which it is understood some other lines are thinking of following. Hitherto they have bought coal-lands and added the price to their bonded indebtedness or other similar burden of 'capital' upon which they continue to seek to earn interest or dividends even after the coal is exhausted; and thereby they have given some ground for the charge of over-capitalisation which the leaders of the miners commonly bring against them.

As for the multitude of small operators, it was sought to control them by offering to fix the contract prices of coal they sold to the roads at 65 per cent. of tide-water prices, and by making the contract cover the

1 Rep. Ind. Com. xix. 462.

2 As to the price paid, sec Rep. Ind. Com. xix. 459 ; and cf. McLeod, ibid. ix. 572 . 
whole life of their properties. There was some difficulty in making them all agree to sign away their freedom for ever; and just what the situation may be at present is not readily ascertained. They are probably kept sufficiently under control, so far as price is concerned, by the railroads' command of the means of transport. They are not equally under control so far as their relations to their men are concerned; and herein consists one of the present industrial difficulties. It will be remembered that they probably still mine about one-fifth of the output.

These consolidations and other arrangements, it will be seen, still left some seven great companies facing one another. It is in the plan which has been resorted to to prevent their unlue competition that the chief novelty of the present system lies. This is the now famous rommunity of interest plan. ${ }^{1}$ It is really very simple-nothing but the acquisition, through purchase or exchange, by a few large capitalists who are disposed to work harmoniously together, of sufficient stock in all the roads to secure a powerful influence in their management. Some optimistic financiers seem to think that this plan, which has been largely adopted in several of the great industries of the country, will quite prevent any great disaster in the future, by bringing to the support of any one interest in danger the financial backing of all the others. Whether this is so or no, the plan does appear to have been pretty effectively carried out in the case of the anthracite roads. No one knows exactly which roals are concerned or to what extent; but it seems to be evident that, for the last three years, the anthracite roads have all of them-including even the Pennsylvania-followed a common policy 


\section{NORTHERN OR} WYOMING

\section{F I E L D}
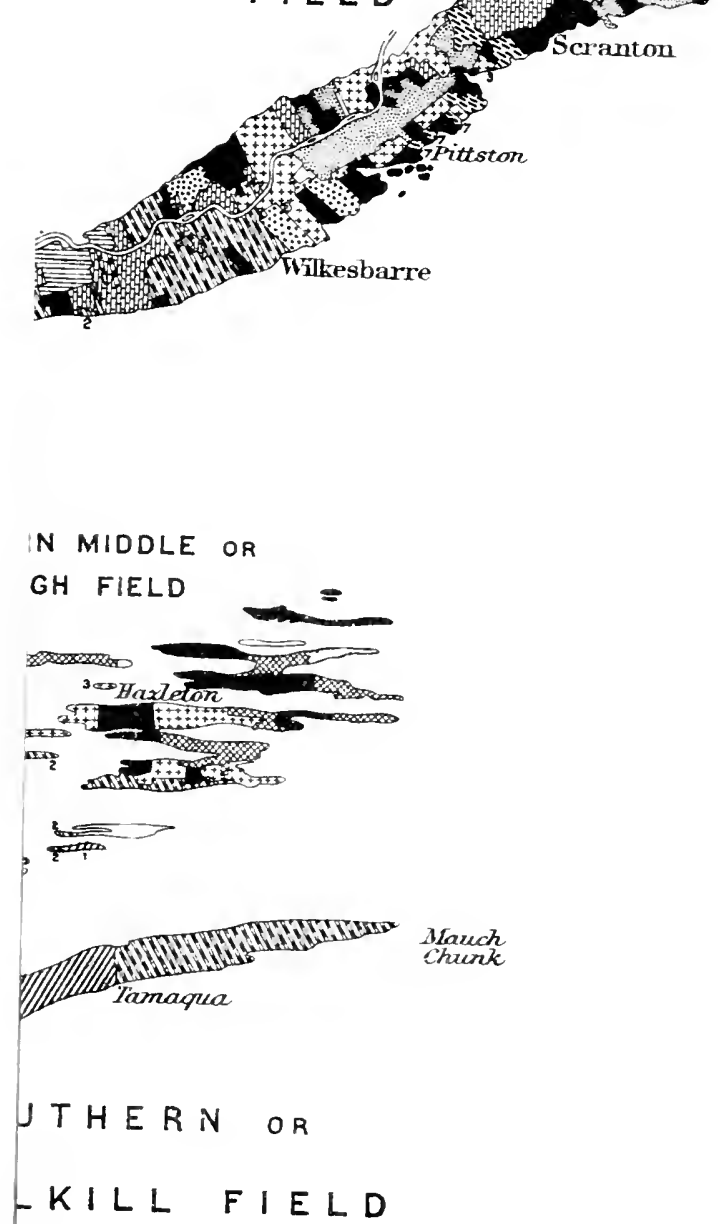


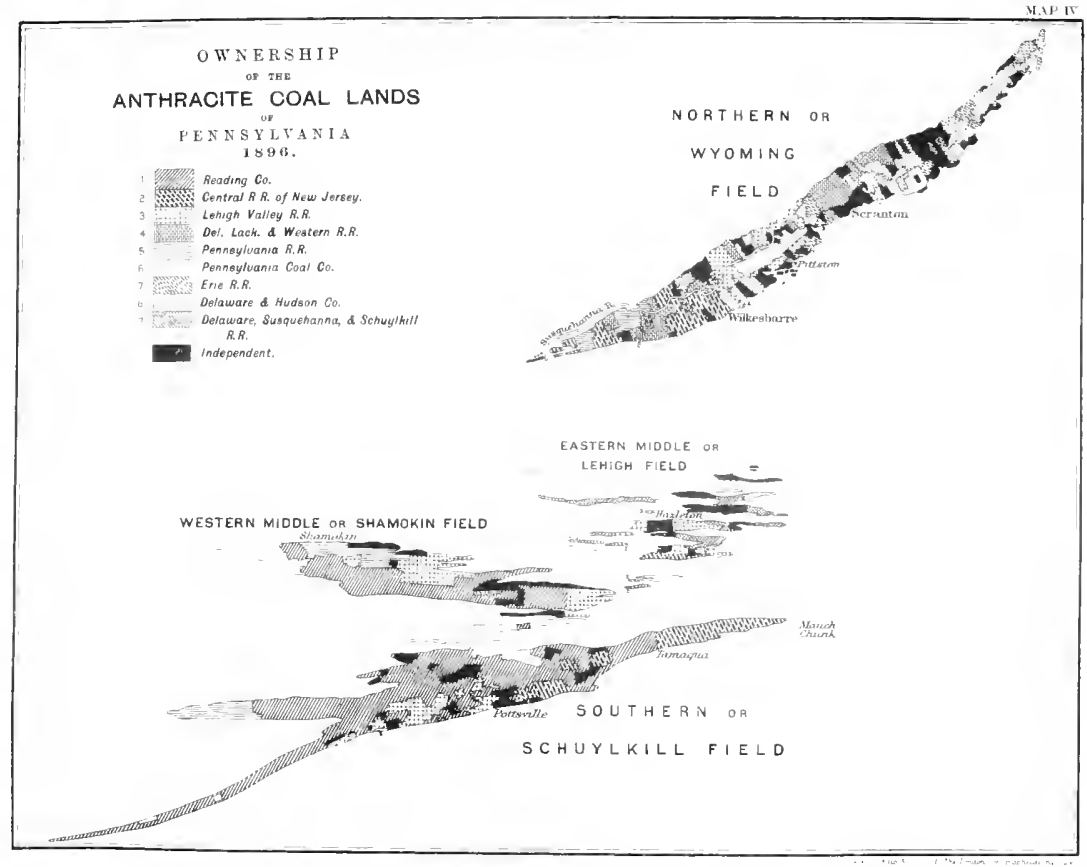


with regard to price and with regard to quotas of tonnage.

Capitalistic combination, we may then say, is now to all intents and purposes complete in anthracite coalmining. It may have been hastened by exceptional ability now and then; but to anyone who has looked into the history of the matter it gives the impression of some slow-moving natural phenomenon, working itself out to completion almost without the intervention of the human will. These 'coal barons' are, after all, not long-sighted schemers; they are very ordinary men, moved, whither they hardly know, by every day's pressure of circumstances. Their primitive philosophy is one of individual enterprise; like most Americans in business, they are fair examples of the 'economic man ;' and, if umrestrained competition has ever had a fair chance in the world and failed-not on account of government action or any other exceptional circumstances, but just because it is in the long run opposed to the nature of things-it has been in Eastern Pennsylvania. ${ }^{1}$

But what has all this to do with the organisation of labour? This: that, even if other circumstances had been favourable, the operators were for many years far too much taken up with the commercial struggle to have any time or thought to spare for the inclustrial side of their business. Moreover, in the central and southern anthracite fields, there existed a sliding-scale arrangement whereby miners wases varied with the price of coal at tide-water; and this quite satisfied the conscience: if wages went down, or employment

1 For the economies possible under combination, see the testimony reviewed in Rep. Ind.Com. ix., Digest xxxii. 
dwindled, masters and men were but partners in misfortune. How unfavourable, however, the other cilcumstances were the history of the sliding scale itself suggests. From the evidence of both sides before the recent Industrial Commission one would gather that the sliding scale was the invention of the operators in 1875. So great are the changes in American life, so complete, in particular, the chasm which divides this seneration from the preceding in anthracite mining; that it is only academic historical investigation which brings out the fact that the sliding-scale method was originally forced upon the operators in 1869 by tradeunion pressure." There was then a strong union-the Working Men's Benevolent Association-in the anthracite regions, composed of miners of American and British blood, officered largely by men who had had experience in English and Welsh unionism. They followed contemporary English precedent in urging the adoption of the sliding-scale principle; there were the same difficulties as to the basis, and as to the proportions in which wages should follow prices-difficulties which were referred to arbitration; and there were heroic attempts in 1871 to found district boards, composed of three miners and three operators, with an umpire, to settle all local questions. ${ }^{3}$ But all this machinery came to an end in 1S75. "The long strike' in that year ended in the unconditional surrender of the men and the destruction of the Workmen's Benevolent Association; the sliding scale was retained for the convenience of

I Report, ix. 583, xii. 146.

* Dr. Virtue's article on 'The Anthracite Mine Laborers' in Lulletin 13 of the Department of Labor (November 1897) presents some of the work done by him in the Graduate School of Harvard University.

3 Somewhat like the joint committees of the North of England. 
the operators, but there was no longer a joint committee to ascertain selling prices in a way satisfactory to both parties. The destruction of the union was soon followed by an almost complete change in the personnel of the labouring force-men of American and English stock leaving, or putting their sons into other occupations, from chagrin at defeat, from ambition to rise in the world, from indisposition to work by the side of foreigners, and half a dozen other motives, and their places being taken by 'Huns' and Poles. No continuous union tradition could survive under such circumstances. Moreover, about this time the Reading and some other railroad companies began to enter into mining, and the consolidation of mine properties began to take place apace; and if the formation of larger competing units makes combination easier when they wish to combine, it makes competition keener when they wish to compete.

For almost a quarter of a century the operators in the anthracite district were practically untroubled by strikes; and here. again, in the matter of industrial administration, the policy of 'freedom' was given a fair trial, if ever it was.' And the result is a sufficient comment. It was not so much the irregularity of employment; that might be ascribed to the nature of

1 " We had twenty-three years of perfect peace-nothing to trouble us in our mines anywhere,' said a leading operator, $\mathrm{Mr}^{\prime}$. Olyphant, in the operators' interview with the Commissioner of Labor, June 10, 1902 ; Bulletin 43 of the Dep. of Labcr, 1210. Cf. the remarks of Dr. Virtue in Bulletin 13 (1897), 748: "Since the failure of the strike of 1887-8 there has been no organisation of importance among the anthracite miners. . . The great obstacle to union here, as elsewhere, is lack of confidence and faith among the members; and scarcely anywhere is that obstacle so great and so hard to remove as among the coalminers. Here is ignorance... in an unusual degree; ... a marked dissimi. larity in race, language and religion; ... and above all the steady, united opposition of the operators to the rise of any sort of labor organisation.' 
the industry. It was not so much that wages were low, for that may be disputed-and lowness of wage is relative; but it was that the whole mechanism of industrial remuneration was allowed to become antiquated and unbusinesslike (if 'businesslike' means a compliment). To pass over a crowd of other grievances -companies' stores, companies' tenements, docking, monthly parment (in spite of the state law demanding fortnightly payment), absence of check-weighmen, \&c. - look only at the matter of the charse for gunpowder. The miners use a good deal of gunpowder in blasting. This they buy of the operator. and they had to pay $\$ 2.75$ per kew for it. It became well known that it cost the company wholesale from 90 cents to $\$ 1$. The defence of the operators was that this price had been agreed upon at some earlier period to offset an adrance in wages. But, if so. why not readjust the wages and charge the market price for powrer? Can anything be imagined more calculated to create constant irritation? The fact is that mless there is pressure from the employed-especially when there is fierce competition among the sereral concerns in the businessthere is often far too little inclination to give serious attention to the management of the labour. So long as labour is quite passive, it does not attract the attention of first-rate business ability; the task of watching the market is quite interesting and absorbing enough; and industrial administration does not present itself as a matter of high policy until some day ' labour' stops the machine. The London Dorks are a case in point.

The tro great strikes of 1900 and 1902 hare been due to the extension to the anthracite region of the influence of the great union of soft-coalminers-the 
United Mine Workers. Flushed with their success in the great bituminous strike of 1897 , and in the establishment of the Joint Agreement system in the conpetitive soft-coal area, it was inevitable that they should turn their attention to the anthracite field-inevitable because of mere fellow-feeling; inevitable also because of that love of national completeness of organisation which is so prevalent in all directions and among all classes in America; inevitable, finally, because there is still some competition between bituminons and anthracite. In a rough sort of way we mar find a parallel in the extension to South Wales of the Miners' Ferleration of Great Britain. After a strike of forty-two lays the struggle of 1900 ended in an armistice, in which the adrantage was on the side of the men. Entering into the strugole with a membership of less than $\$, 000$, the union came out with a membership of $100,000 .^{1}$ The degree of solidarity which the 'national organisers' succeeded in bringing about among a population composed of fonteen nationalities, is indeed marvellous. One considerable independent operator had for years made it a part of the contract of hire that all difficulties should he submitted to local arbitration, and that his men should never strike. Nevertheless, most of his men went on strike in order to secure a general settlement. How far they were justified would depend in some measure on the extent to which it had been a voluntary and conscious contract. Less doubtful was the propriety of the miner's' refusal to accept concessions from a single railroad-eren though that road was the Reading, employing. 25,000 out of the 130,000 men on strike-until all the operators would accept a conmon settlement."

'Rep.Ind. Com. xvii. $190 . \quad$ 'Itid. 191. 
The settlement in 1900 was premature and unstable, because it was brought abont not by economic but by political forces. Mr. Baer, the present president of the lieading Railroad, has recently told us the story:

"Shortly after this strike was inaugurated, Senator Iranna' - the most influential of the Republican politicians --' Inet a number of gentlemen and insisted that, if the strike were not settled, it wonld extend to Ohio, Indiana, and Illinois, and the election of Mr. McKinley and Mr. Roosevelt would be endangered. He insisted that he was anthorised to settle the strike through $\mathrm{Mr}$. Mitchell if the operators would asree to a 10 per cent. advance in wases. After a good deal of pressure had been brought to bear upon the presidents of the coal companies, and positive assurances were given that the situation was really dangerous, President Mchinley sending to me personally a gentleman to assure me that Ohio and Indiana were in danger unless some adjustment were made, we agreed to put up a notice which was prepared, as we understood, at Indianapolis, and furnished by the United Mine Workers.'

What did the men secure? They gained an immediate rise in wages, and the gmpowder grievance was redressed. The sliding scale was abolished.2 But there was no provision for future readjustments of the rate, nor for the settlement of local disputes. The miners aroued: "The anthracite coalowners form a combination - -it will be remembered how very appropriate this arement was in 1900. "If combination is good for capital, it is good for labour. We

' Bulletin 43 of Dep. of Labor, 1204.

"Indeed, if one may trust the account in Roberts' Anthracite Industry, 200, some of the miners' leaders put forward the claim, of which we have heard so much in England. that "wages shonid govern the selling. price, and not price wages.' 
should organise in order that combined labour may do business with combined capital.' ${ }^{1}$ But in this settlement combined capital had refused to do business in any formal way with 'combined labour,' or, as the phrase went, in any way to 'recognise' it. They refused to meet the leaders of the United Mine Workers, and the terms finally agreed upon had come to them through third parties. ${ }^{2}$ And that is why I called it an armistice.

The events of the next two years can only be understood when we remember the sudden collapse of many earlier labour movements in the United States. The success since 1897 of the United Mine Workers in the bituminous districts is probably much more impressive to an average Englishman than to an average American. As I have elsewhere said. ${ }^{3}$ the state of mind of the elderly hard-headed American capitalist is that of Browning's Legate, 'I have knowl four-and-twenty leaders of revolt: Let him but liold on, he thinks, and the trouble will pass awar.

The first great anthracite "impaign terminated at the end of October 1900: the second began in the middle of May 1902. We are not far enough away in point of time to see the events of that period in true perspective, and I lo not propose to play the part of judge, still less that of adrocate. In the course of the second strike the miners put forward certain specific demands with regard to wages, hours of labour, and the weighing of coal, which were to some extent

1 Roberts, Anthracite Industry, 200.

2 Cf. the comment of the New York Nation in its issue for November 1, 1900: "The men have received "concessions," but they do not go back to work under any "agreements." The operators have merely " declared" their intentions and "posted " notices.'

${ }^{3}$ Surveys, 416. 
discussed in the course of the negotiations.' But the preliminary and primary cause of the strike was the refusal of the coal operators to grant 'recognition' to the United Mine Workers' Union. What 'recosnition' means was repeatedly explained in the clearest terms by both parties: it means any form of direct negotiation with the national oflicers of the mion."

The concessions of 1900 expired in April 1301. In March there was a convention of the three anthracite districts, which voted that the national executive boald of the whole union. together with the officers of the three districts, should approach the operators and propose a joint conference to deternine wages for the ensuing year. The operators refused to agree to such a conference; but certain 'outside friends of the labour movement' browght about ' an interview' between the leaders of the miners and certain representatives of the

1 They will be found in Bulletin 43, 1150.

2 It may be worth while to quote two definitions. One will be found in the proceedings of the Industrial Commission (Report. ix. 575), where one of the members of the Commission observed: "We understand that they have upwards of 80 per cent. of the men organised, and that they are moving in the direction of getting recognition for their union; that $i s$, that they shall confer and arrange a scale of prices and fix conditions for every sneceeding year, as is done in the bitmminous regions.' A second is in the Report of Mr. Loomis, Superintendent of the Coal Mining Department of the Delaware, Lackawanna, and Western Railroad Company (in Bulletin 43 of Dep. of Labor, 1191). Under the paragraph-heading Recognition of the Union he says: "The question of ecognition is one that has been prominent before the operators sinee the strike of 1900 . We have agreed to meet committces of our own en:ployees, and adjust any actual grievances. These committees are in most eases selected by the United Mine Workers' Union or so-called "Locals." In other words, we are dealing indirectly with the local unions at the different mines. We have refused, however, up to this time, to deal with any of the national officers of the mion, and have taken the position that they, not being acquainted with the conditions which exist at the different mines, are in no position to talk intelligently about them; and not being our employees have no right to interfere or attempt to dictate to us.' 
coal roads. No authoritative account of what then occurred was given to the public by the operators. The account which the miners' leader's gave to their union was that the operators 'held out the hope that, if during the present year the mine workers demonstrated their willingness and ability to abstain from engaging in local strikes, full and complete recognition of the organisation would unquestionably be accorded at a future date;' ' and with such assurances the United Mine Workers thought it best to be content for the time. The operators, on their side, posted notices that work would go on upon the existing terms for another year -until April 1, 1902; and probably many of them expected, and some of them hoped, that the condition they had imposed would never be fulfilled. There were undoubtedly a good many local strikes in the year that followed, and the operators had some difficulty in maintaining discipline in their mines. However, in February 1902, the United Nine Workers invited the operators ' to a joint conference of operator's and miners . . the object of the conference to be the formation of a wage scale for the year beginning February 1, 1902, and ending March 31, 1903.' The presidents of the various coal companies all declined the invitation; and on March 14 they once more posted their own independent notices in the following terms:

- The rates of wages now in effect will be continued until April 1, 1908, and thereafter subject to sixty days' notice. Local difierences will, as heretofore, be aljusted with our employees at the respective collieries.'

Still once more did the Miners' Convention propose a joint conference, and once more the operators 
dechined; and then the strike was inevitable. ${ }^{1}$ It was only lelayed, and the situation was in no resper.t really altered by the intervention (at the request of the miners) of the Civic Federation. The Civir Federation is an organisation of distinguished American citizens for the purpose of mediation and conciliation in labour disputes. It had alleady lone good service in terminating industrial disputes elsewhere; but its interrention is certainly more appropriate in the case of employers or emploved who possess no strong urganisation of their own. It might also conceivably perform a useful service, when one party to a dispute is really beaten, by enabling it to 'save its face,' and yield gracefully on alleged grounds of public interest. But in the present case the two parties were well organised; they knew their own mind; and it was really better for the community, in spite of the suffering it would occasion, that the fight for which both sides had been 'spoiling' should finally take place. We camnot but feel a certain sympathy with the remark of the President of the Reading Company, 'Anthracite mining is a business, and not a religious, sentimental, or academic proposition.' 2

For it has to be clearly understood that the ultimate arbiter in the industrial world, as in the world of international politics, must be force: the determining decisions an commonly be arrived at only by an avowed or tacit trial of strength. This sounds rery materialistic and brutal ; though, even in ordinary warfare, it has been observed that there must be a man and some sort of human will at the other end of the bayonet. But the statement becomes an economic commonplace when for 'force' we put the more harm-

1 The correspondence is given in full in Bulletin 43 of the Dep. of Labor.

$\because$ Ibid. 1187. 
less-sounding 'forces,' and say that ' the conditions of labour are determined by the play of economic forces.' And this really means the same thing if we include the human will among our forces, and remember that an immediate victory does not necessarily mean a final settlement. "We can get men to do the work for so much.'- 'You cannot get men to do the work for so much.' 'We will not submit to a reduction of profits.''You must submit to a reduction of profits.' Antagonisms like these can only be brought to an issue, in our present society, by a trial of strength. They could only be determined otherwise if we possessed, what we do not possess, an accepted doctrine as to what wages or what profits were in themselves desirable. Of course in the trial of strength, in this instance, the starvation of the men and the bankruptey of the masters, the usual 'sanctions' of the law of competition, were reinforced by the public interest in keeping itself warm in winter. But this also is a 'force,' like others.

As I cannot see my way to joining ofthand in the rondemnation of either party, let me put before you, as fairly as I can, what I understand to have been the contentions of earh. On the side of the men the contention was that the determination of wages by joint agreement was desirable: and we do no injustice to them when we suppose that, in their belief, such 'recognition' would strengthen the union in various ways, and so enable it to secure better conditions-among others, higher wages. On the side of the masters it was argued that such joint agreement was impossible, because the conditions of anthracite coalmining were so complicated that no common agreement was possible on the subject; ${ }^{1}$ that, if possible to start

' This was put in different ways by different operators. Mr. Baer, 
with, the difficulties of "interpretation" would be insuperable, and would caune so much friction that it had better not be attempted. Moreorer, such an agreement, they declared, would mean submitting to the 'dictation' of the men, and being compelled to give higher wages, which the tracle could not aflord. The men of course aroued that the trade rould afford to pay higher prices. The operators urged that the union had not prevented unnecessary local strikes, and that the men had often been unruly and untrustworthy. The union replied that if it were "recognised, as in the bitmminous districts, it wonld have mole hold upon the men, and would 'discipline' them itself. The operators on their side again alleged that the union was everywhere trying to compel men to join the soreiety, and declared that 'every man has an inalienable right to work.' ' To which the union could reply that a practically universal membership was a condition precedent to eflective union action, and that it was their business to get all the men in by legitimate means. As to the means, there is usually a strange reluctance on the part of the intelligent public to face the facts of human nature. Of course there is a sreat cleal of coercion in cases like this of the anthracite union-coelcion which begins with denunciation and goes on to hustling, and the President of the Reading Company, argued that it was impracticable to form a wage scale for the whole anthracite region, and declared that 'the dissimilarity between anthracite and bituminous mining is so great that it does not follow that any success attending the creation of a uniform wage scale in the bituminous region could be repeated in the anthracite fields.'-Bulletin 43 of Dep. of Labor, 1176. The President of the Scranton Coal Company went further, and said that even a conference of all his own miners would be impracticable.-Ibid. 1182.

1 Mr. Thomas, representing the Erie Railroad, went on: 'And if he is required to have a licence from a labor leader to do so, I say the time has come for a new Declaration of Independence.-Ibid. 1215. 
may go on to a good deal worse. Considering what the population was in the anthracite fields, we may be surprised that there was not much more violence. Of actual physical violence there was, indeed, hardly any ; and the public authorities ought to be strong enough to prevent it. But no display of police can make a small minority really quite free to do as they please in the midst of a great majority imbued with unionist principles. In the case of 'a natural craft,' such as the coalminers form when they constitute the bulk of the population, the question for a business administrator is not one of ethic's, but one of intelligent forecast of circumstances. Are the great mass of the miners really united, and how long are they likely to hold together? The event proved that they could hold together for several months, long enough to terrify the people of the United States with the dread of cold; and the event proved also that there was substantial unanimity among the men. ${ }^{1}$ Uncler these circumstances the criticism to be passed upon the operators is not that they dicl something morally wrong (the matter is by no means clear enough for any such condemnation), but that they showed defective business judgment. Anticipation of the way in which masses of men are likely to act is just as much a matter for 'business sense' as anticipation of the market.

Further comment is best postponed until the President's Commission has made its report. ${ }^{2}$ Meanwhile it is worth while observing that Mr. Carroll D. Wright, the well-known statistician, who has been engaged in the study of industrial affairs for thirty

'The impressions of an eye-witness will be found in Dr. Roberts' article on 'The Anthracite Coal Strike in its Social Aspects' in the Economic Journal for March 1903.

2 See the Preface. 
years, and who as Commissioner of Labor was asked to look into the matter in June last and report to the President, does not think the difliculties in the way of a joint agreement insurmountable. But he suggests that the agreement on the part of the operators should be made with a "new' 'anthracite coalminers' union, in its autonomy to be independent of the United Mine Workers,' 1 though possibly affiliated with it. The operators have betn very sore, or have professed to be sore, at the invasion of their district by a soft-coal mion "which has its headquarters in the State of Indiana.' It is something like the annoyance of the South Wales coalowners at the interference of the Miners' Federation of Great Britain. But, in the first place, but for the action of the United Mine Workers the anthracite miners would have remained unorganised, and would not have secured the concessions of 1900: without their heip, the anthracite unions are much more likely to fall to pieces, both berause of their more composite foreign membership, and also because of the greater consolidation of capital in this field; and, so long and so far as anthracite and bituminous coal compete in the same markets, a common policy is economically justifiable. I conjecture that the miners will think themselves bound in honour not to dissociate themselves from the soft-coalminers; and even if they announce their readiness to do so, the necessities of the situation will force them into unity of action practically indistinguishable from unity of organisation.

And now let us return to what we have seen of the organisation of capital in the anthracite field. With the establishment of 'community of interest' on the

${ }^{1}$ Bulletin 43 of Dep. of Labor, 1166. The text of Mr. Wright's suggestions is given in Appendix IV. 6. See also Appendix VII. 
capitalistic side, some of the chief causes of the unsatisfactory industrial conditions of earlier years have already disappeared. The operators are sufficiently united to enter into and carry out a joint agreement if they wish to; the lessening of the commercial tension, with the moderating of competition, leaves them time and energy for what is undoubtedly a difficult and delicate business-the drawing up of a common rate, and its adaptation to particular circumstances; while the non-recurrence of periods of 'cut prices' will make it possible for them to pay fairly good wages, and that more regularly. And, as to the relations between the anthracite and the bituminous districts, it is more than possible that the connection will at no distant date grow closer on the capitalistic side. It is an open secret that some of the capitalists who now control the hard-coal output have already begun to lay their plans for bringing soft coal under their direction: and this by their command of the railways. ${ }^{1}$ If they should succeed in their project, it will be too ridiculous to object on principle to a combination of the men who hew the two kinds of coal. The American people prides itself on its sense of humour.

${ }^{1}$ Brooks, Social Unrest, 19. During 1899 and 1900 four of the great soft-coal carrying roads, the Pennsylvania, Baltimore and Ohio, Chesapeake and Ohio, and Norfolk and Western, were brought under one control. These do not operate mines, but they are able by combination to 'abolish to a considerable extent the competition of different coals in the same market which caused low prices to the mine owners.'-Rep. Ind. Com. xix. 230 . 


\section{LECTURE VII}

THE IRON INDLSTRY IN GREAT BRITAIN AND AMERICA

I HAVE taken so long over coal that I shall be mable to deal as I had intended with iron and steel, except in the most rusory mamer. There are, however, a few things I should like to say in a summary way about England, and then we will return to America. The whole field of the iron industry and a larce part of the field of the steel industry in Great Britain is corered by a network of boards of conciliation. There is the oldest of them, The Board of Conriliation and Lrelitration for the Manufartured Fron and Steel Trate of the North of England, whose thirty-fourth annual report has just been issued. ${ }^{1}$ There is The Midland Fron and Steel. Wages Board, whose twenty-seventh ammual report was presented at Birmingham this moming.2 At Glasgow the two branches are divided, and there is The Board of Conciliation and Arbitration for the Manufartured Steel Trade of the West of Scotland, now in the thirteenth year of its existence; ${ }^{3}$ and The Scottish Mamufactured Iron Trade Conciliation and Arbitration Board, established six years ago. ${ }^{4}$ In South Wales there is The Welsh Plate and Sheet Conciliation

1 Given in Appendix V. 2.

2 Narch 2, 1903. Its Pules and Sliding Scale, together with a typical Quarterly Report, will be found in Appendix, V. 1, V. 1A, and V. 1B.

${ }^{3}$ Its rules are given in Appendix V. 4.

${ }^{4}$ Appendix V. 3. 
Board, now in its fourth year. ${ }^{1}$ Horeover the Association of Steel Ingot Manufacturers (embracing both the North-East Coast of England and the West of Scotland) has been in the habit, for some years past, of arranging rates of wages in informal conferences with the Steel Smelters' Association.

In the case of 'manufactured,' i.e. puddled or rolled iron, the wages of puddlers form the basis in relation to which the remuneration is determined of all the other classes of operatives employed. The blast-furnacemen, making the crudest form of iron, pis-iron, which serves as raw material to the puddler, fall within the operations of another series of similar mechanisms. There is The Board of Conciliation established letween the Ooner's of Blast Furnaces in Siotland and the Scottish Blast. Furnaremen; and though in the Cleveland district there seems to be no permanent board, wages are determined by a sliding scale. set forth in an Ayreement between the Cleveland Irommusters' Association and the Representatives of the Blast-Furnoremen employed at the Associuted Wriks, which provides that all disputes shall be referred to a Committee representing the two parties. Nor are the irmfmnders, or even the comparatively snall body of pattem-makers who serve them, without their boards where their numbers are at all large. And at Newcastle there meet periodically the Board of Conciliation for the Ironfinemeling Industry of the NorthEast Coust (since 18.4), and the Board of' Conciliation jor the Pattern-maling Incinstry of the North-East Coast. All these boards, I believe. are working pretty well ${ }^{2}$

1 This is of peculiar interest, since it provides for the representation on the board of four workmen's unions-the Steel Smelters, the Tin and Sheet Millmen, the Doekers, and the Gasworkers. The rules of the workmen's section are given in Appendix V. 5.

${ }^{2}$ For the rules of three of the last mentioned, see Appendix V. 6-8. 
In the Midland Iron Trade, about which I am naturally best informed, there has been no strike for a good many years. Recently, at the suggestion of the Operatives' Section of the Standing Committee, Sir Benjamin Hingley was presented by the board with his portrait, in recognition of his services as chairman for twenty years-at a cost, coming out of funds provided almost equally by the two parties, of 325 guineas!

Now the first thing to observe is that all these boards depend for their eflicacy on the existence, and practical recognition by the employers, of strong trade unions among the men. On the north-east coast the Constitution of the Ironfounders' Board expressly states that 'the parties to the Boart are the Associated Employers of the Tyne, Wear and Tees and Hartlepool Districts, and the Friendly Society of Ironfounders of England, Ireland, and Wales.' The Associated Employers now, I understand, form the North-East Coast Association-a member of the great Employers' Federation of Engineering Associations; while the Friendly Society of Ironfounders, extending through the whole of the country, has some $1 \$, 000$ members, an annual income of some $£ .5,000$, and mexpended funds amounting to $£ 100,000$.' Similarly 'the parties' to the neighbouring pattern-making board ' are the NorthEast Coast Engineering Employers' Association and the United Pattern-makers' Association ; and the patternmakers, though there are necessarily only few of them, some 4,800 , have funds to the amount of about £s per man. All the other boards, following the example of the oldest, that for the Manufactured Iron Trade of the North

The only recent breakdown of a board has been in the case of South Wales Siemens Steel. This expired, or passed into a state of suspended animation, some eighteen months ago, after an activity of three vears.

1 Figures in Board of Trade Report on Trade Unions for 1901, 122. 
of England, carefully avoid any formal 'recognition ' of the union. The reason is, of course, that the creation of the North of England Board goes back some thirty-four years, to a time when unionism was only beginning to obtain respectful treatment, and when the principles on which rests the successful working of such bodies were not so clearly understood as they are now coming to be. The phrases used in erery case are such as the following: "The board shall consist of one employer and one operative representative from each works joining the board;' 'the operatives of each works shall elect a representative by ballot;' 'the chairman shall be appointed by the employers' section from among their body. The vice-chairman shall be appointed by the operatives section from among their body. A secretary shall be appointed by the employers, and a secretary shall be appointed by the operatives,' \&c. ${ }^{1}$ One might read through a score of the board's reports and not guess that there was such a thing as a mion in existence." But all this time the operatives' representatives are to all intents and purposes representatives of the union, and the operatives' secretary of the board is invariably a leading official of the union. Thus the national Secretary of the Associated Iron and Steel Workers is the secretary of the North of England Board; and the national Secretary of the similar Scotch society, the Amalgamated Steel and Iron Workers, has been the operatives' secretary on all the three Glasgow boards. It is undoubtedly the case that the fighting strength of the unions sometimes secures them better terms than the masters' own judgment would volun-

1 See the Constitutions of these Boards in the Appendix.

2 This coy reticence is, however, passing away. Thus the Report of the Midland Iron and Steel Wages Board for 1901 explains the recent legal action taken by the Ironworkers' Association and its Secretary. 
tarily offer : on the other hand, the strength of the union is the only guarantee that the mutual agreements will be lovally arcepted by the men.' Perhaps our characteristically British and indirect way of doing a thing, without saying we are doing it, might contain a useful suggestion for the American anthracite situation.

The second point to observe is that throughout the mannfactured iron trade (with the exception of the ironfounders), as well as in several branches of the steel trade, weneral rates of waces are determined by shiding scales. In the case of the manufactured iron trade of the North of England and of the Midlands, the scale has been long established and works automatically. Wages are in a fixed ratio to the 'average net selling price, deduced arcomding to recognised rules from the quantities and prices of the various descriptions of iron as ascertained by areountants every two months. Tn the case of the Midland Board, the principle is recognised that wages shall be rid. per ton above the North of England rate for purdling, in order to make up for certain northern "extras.' and therefore that if the accountant's ascertaimment does not sive fid. above the northern late the lifference shall be made up. Some irritation is occasionally felt by the men

' It may be worth quoting the following express recognition of this necessity for strong unions for the purpose of pcaceful adjustment of wages by Mr. Trubshaw, Chairman of the Masters' Association in the South Wales steel industry: "He did not in the least object to their being affiliated with a union, but what he held was that it was absolutely necessary that the union should be a strong one. Now that the masters had a strong association and the men were banded together in a strong union' (the British Steel Smelters' Amalgamated Association) 'he felt quite satisfied that their deliberations ... would end in peace. . . . He was glad to see a number of the boys and youths of the trade present with the seniors that night. He would like to take the opportnnity of asking them to join some strong union, so that they might be guided in their actions.'-British Steel Smelters' Monthly Report for February 1900, 87. 
in this, as in the coalmining industry, when newspaper reports of advances in the price of iron are not immediately, or not at all, borne out by the ascertainments of realised prices ; ${ }^{1}$ and it is much to the credit of the men that they acquiesce so readily in the assurances of their representatives that the prices are fairly returned. The Scotch Iron Board, formed in 1898, has, indeed, been unable to agree upon a permanent sliding scale, in spite of the strong feeling of the employers that 'the best method of preventing difficulties' is an 'automatic system, independent altogether of the opinions of either side.' $^{2}$ But a certain rate for puddling in proportion to realised price-formulated in the phrase 'shillings for pounds, plus 2.s. Gid. premium net'3-having been provisionally agreed upon until a permanent sliding scale should be drawn up, it has been continned from time to time by vote of the board for so-and-so many 'audits,' ${ }^{4}$ and seems almost as firmly established as if it had been formally arcepted. The representatives of the men explained to the employers in feeling terms how hard they found it to arry their men with them: - Our delegates.. a are placed in a very peculiar position. They have to meet in their works sometimes hundreds of men who do not understand how the award has been arrived at, what has been done here, or the arguments which have been used on both sides.' And the men's representatives are therefore naturally loath to tie their hands nore than they can help, especially as they realise that they "are only beginning just now to grasp the business side of the iron trade." "J

1 Midland Report, July 1902. Cf. Scotch Iron Minutes of September $15,1898,15$.

${ }^{2}$ Minutes of Meeting, September 15, 1898, 2.

${ }^{3}$ Ilid. 27.

${ }^{4}$ This is a common Scotch equivalent for the English 'ascertainment.'

"Minutes of Meeting, September 15, 1898, 3. 
We have already seen that the Midland wages are arljusted so as to be equiralent to those of the North of England. Similarly the Scotch irommasters represent that they cannot pay higher wages than their North of England rivals. ' There is a general desire on the part of both parties in each district that wages should everywhere be 'on a level,' and there are no great difficulties in the way of discovering the facts. But the circumstance that Wnglish and Scotch ironworkers belong to different unions renders it less easy than it might otherwise be for either set of men to be thoroughly well informed of conditions elsewhere.

In the case of blast-furnace men mannfacturing pig-iron, the scale of wages follows the quarterly ascertainments of the net average selling price of the pig-iron. In the Middlesborough district this is taken for convenience as sufficiently indicated by ' $\mathrm{No}$. 3 Cleveland Pig-iron.' The nominal 'standard' is paid when the price is between $34 . s$ and $34 . s .2 .4 d$.; and the scale provides for price falling to $29 s$, with a deduction from standard of 6.25 per rent.. and rising to $60 \mathrm{~s}$ with an arddition to standard of 35 per' rent., 'and so on in either direction in the same ratio;' although it is agreed that for 'spare furnaremen' there shall be a 'minimum rate of wage' of $3 s$. a day.

And finally, at the other end of the manufacture, in the manufactured steel trade of Scotland, while there is no formal sliding scale, there is an informal one, inasmuch as 'a rise or fall of 10 s. per ton in the price of steel plates is taken to mean a rise or fall of 5 per rent. in wages.'?

1 Minutes of $1900,22$.

"From MS. Notes kindly furnished to me by Dr. Dyer, the Vice-Presi. dent of the Scotch Manufactured Steel Board. Dr. Dyer goes on to explain 
I must content myself with this exposition of the actual state of aliairs, and can only just touch in passing upon the interesting question why the sliding-scale method seems to possess so much vitality in theiron trade, while it has had to be abandoned in name and greatly modified in practice in the coal-mining industry. Probably the explanation is to be found in two circumstances. In the first place, the 'long-contract' or 'selling-ahead' system, which, as we have seen, has always endangererl the sliding scale in the coal industry, does not exist at all in the iron and steel trades. The reason is thus given by the Serretary of the Associated Tron and Steel Workers:

- In coal, wayes and demand are perhaps the two principal factors in the general selling price, while in our own trade wages count but little; demand does not always count much more, but the price of ran material is the detemining fartor, perhaps more than in any other industry. This varying, uncertain and ofttimes bewildering finctuation in the prices of raw materials renders long contracts in the iron and steel trades too dangerous and speculative; and so our wages under our sliding scales respond more readily to the

that "the difliculty is to fix when a price has been established. Both sides have hitherto taken my decision on this point after an examination of the order books of a few representative firms.' The Sccretary informs me that "other departments in the works of the firms connected with the board base their clains, or are arranged with, according to its decision.' The wages of the steel smelters employed by the ingot makers of the NorthEast Coast and the West of Scotland apparently follow in practice the nett selling price of ship plates. I am informed by the Secretary of the Smelters' Association, Mr. John Hodge, that in the abortive negotiations some years ago for the creation of a formal Board, the union expressed its readiness to accept a sliding scale definitely based upon the ascertained prices of plates. This they agreed to for the sake of the advantages of an 'autonatic' regulation of wages, in spitc of some theoretic difficulties not unworthy of consideration. 
actual conditions of trade than would be the case in the coal tracle: '

And, in the second place, there is some reason to believe that combination anong the employers has been more successful in "lesulating" prices in the iron than in the coal industry. The Marked Bar Assoriation in the Midlands is reputed to be notably efficient in that direction; and the significance of the fact is apparent when one observes that "ham form the most considerable item in the acrountants ascertainments. And in the North of Fugland there is said to be 'a lirm grip' upon prices by the manufacturers, adjusted according to the price of raw material and the general state of the matrket."

No wide diveronce between the inchustrial policies of laroe bodies of men is ever withont its explanation in the surrounding circumstances. If these two causes explain the diflerence between the ironworkers and the miners, the former are ready to have their wages determined by prices simply because the movement of prices means to them something different from what it means in the case of coal.

It may be asked, however. what there is for a board to do if wages are determined antomatically in accordance with an agreed scale. If the scale will work quite antomatically, there is no need for a board so far as general rates are concerned; and so the Cleveland irommasters and blast furnacemen, with a scale agreed

' From a Letter from the ironworkers' Secretary, Mr. James Cox.

"From Mr. Cox's Letter. I have been glad to find that these two suggestions, which I laid before $M T r$. Cox and in which he concurred, also meet with the concurrence of Mr. Daniel Jones, the employer's' Secretary of the Midland Board, himself a man of experience as a manager of ironworks. It is noteworthy that at the Scoteh blast furnaces a minimum and maximum form part of the Agreement; see $\$ 2$ of Schedule in App. V. 5. 
to for three years, have no board. But it is a good thing that the two parties should meet periodically; it promotes mutual understanding. Moreover, the scale may seem to one or other party to require revision from time to time, or the number of descriptions of iron to be included in the ascertaimment may need to be added to or lessened. Still, the annual meeting of the full board is naturally rather formal. More activity is shown by the bi-monthly meetings of the smaller standing committee, whose business it is to settle questions of interpretation and of application to unusual circumstances.

Particular grievances are commonly referred by the standing committee to the two secretaries, who are frequently empowered to visit particular works and try to arrive at a settlement. And it is interesting to see how great is the assistance which the operatives' secretary (usually, it will be remembered, the secretary or president also of the union) renders to the businesses represented, by removing trivial misunderstandings, and by inducing the men to continue at work while their grievances are under consideration. ${ }^{1}$

Returning now to America, you will not be surprised

1 "It is a matter for" congratulation that during the lattel' half of the year no complaints have been before the board. this being to a great extent due to the faet that Councillor Cronin and the operatives' representatives at the various works have been able to adjust any disputes which have arisen.'--Minutes of the Fourth Annual Meeting of the Seottish Manufactured Iron Trade Conciliation Board, January 1901, 12. 'It is a remarkable fuct that during the year nut a single case from the works has been submitted to the standing committec. This may be aceounted for, to some extent, by the greater efficiency and recognition of their duties by the operatives' works representatives, the intervention of the operatives' secretary, and in a large degree to certain principles having been laid down in past years by the decisions of the standing committee.'Annual Peport of the Midland Tron and Steel Wages Board for the year ended December 31, 1902. 
to learn that the fundamental ideas of oromised labour in the iron and steel industry in that comntry do not creatly differ from those in vogne in England. In what I have to say of the matter I shall be compelled to limit myself to the years before the smmmer of 1901 , the date of the steel strike. There has yet been hardly time to see what is going to be the ontrome of the events of that year.

There has existed for more than a quarter of a century a lare and, for much of the time. a powerful mion known as the Amalgamated Association of Iron, Steel, and Tin Workers of the United States-itself, as the name intuplies, a comsolidation of some much older bodies. It was one of these sorieties, the United Sons of Trulean. (omposed of the puldlers around Pitsbure, which drew up in 186i.j, in concert with representative employers, what seems to have been the first sliding sale in aither America or England." The Amalgamated Association has chung to the old tradition. The iron trade has widened and split up into several branches. and the new methods of mannfarturing soft steel have enormonsly enlarged and modified the industry. The Amalgamated Association has endeavoured, with a fair measure of success, to include all the new lorandhes and to rover the whole of the country. The Inerican passion for "ompleteness has so far prevented the growth of geographically rectional societies, like the English Assoriation and the Scotch

1 Rep. Ind. Com. xvii. 339. The text of the "Memorandum of Agreement, made this thirteenth day of February 1865, between a Com. mittee of Boilers and a Committee for the Iron Mannfacturers, appointed to fix a scale of prices to be paid for boiling pig.iron. based on the mannfacturers' card of prices 'will be found in Mr. Carroll D. Wright's article on the history of the Amalgamated Association, in the Q. Jour. of Economics for July 1893. Cf. Mrunro in Scales in the Iron Industry, 2. 
Amalgamation, or the splitting-off of the steel worker's from the iron, which seems to be taking place to some extent in Great Britain. And throughout, the Amalgamated Association in America has abided by its policy of annual ronferences and joint agreement to sliding scales. The state of things in 1900 and the years immediately preceding was that four scales were drawn up annually by as many divisions of a general Conference Committee appointed at the annual Convention of the Association, in consultation with the several interests inrolved. It is significant that by 1900 those other interests were no lonser represented, as they had been, by assoriations of manufarturers, but by single great companies which had taken the place of the indiridual employers. Thus one division negotiated a scale for boiling (i.e. puldling) ant allied processes with representatives of the Republic Iron and Steel Company, instead of with the Association of Bar-Iron Manufarturers. hecanke that company now inchuded most of the bar-iron mill. A rerond division negotiated with the same (ommprny a wale for iron bars and plates and allied products. I third conferred with representatives of the Anerican Sheet Steel Company, which included nearly all the sheet steel mills in the country, and no longer with an Isworiation of Iron and Steel Sheet Manufacturers. And finaliy, a fourth negotiated with the American Tinplate Company, which had brought together nearly all the tinplate mills. ${ }^{1}$ The method of conference seens to have been less cumbrous than that of the soft-coalnininers, and the Conference Committee seems to have been more independent of the Convention. Besides these ceneral agreements, there

1 The substance of the Agreements for 1900 will be found in Appendix VI. 2. 
were local agreenents in the case of rail mills and other establishments not corered by the general conferences.

In all the agreements for different classes of iron the sliding scale followed the price of bar-iron, as ascertained every two months. ${ }^{1}$ In the case of the baliron mills, the manufacturers employed an expert, called an Adjuster, who enjoyed the confidence of both sides. It was his business, in conjunction with a small committee, to report bi-monthly as to what the average price had been for the preceding period; and it was his duty-and a duty rery successfully performed - to settle with the officials of the union any disagreement that might arise as to the construction of the agreement." Each scale, it must be remembered, was only agreed to for a year: and it always contained a minimum proviso. ${ }^{3}$ In 1895 the Amalganated Association numbered 34,000 members in 2!rl) local mions.

But though the Association included, it would seem, most of the skilled operatires in most of the iron and steel "mills of the comntry. or at any rate of those turning out the more finished forms of steel, it by no means included all. One great exception was the large Carnegie plant at Homestead, near Pittsburg. There an ill-advised strike in 189.2, one of the most terrible in its incidents that has ever occurred even in America, had absolutely destroyed the local mion, and had created a state of aflairs in which no man dared join the Association. I gladly relieve myself of the responsibility of pronouncing upon the merits of the dispute

1 A statement of prices between 1837 and 1897 is printed in Appendix VI. 1.

2 An account given by himself of the duties of the Adjuster, Mrr. James II. Nutt, will be found in Appendix VI. 3. The ascertainments are based on the sworn statements of manufacturers.
"Rep. Ind. Com. xrii. 339 seq.
4 Irid. 213. 
by referring you to what seems an impartial account of the strike, to be found in the Economic Joumal for 1893 , from the pen of my Harvard colleague, Professor Taussig. ${ }^{1}$

The Carnegie mills were not alone in being nonunionist; many of the mills in the great capitalist combinations just referred to (though apparently usually a minority in each branch) had not been unionised in 1901; and the scales signed annually as the result of conference, while they might have more or less affected the wages paid in others. were only definitely agreed to so far as the mills which the company recognised as union mills were concerned. The agreement, e.g. for 1901-2 in the tinplate branch opens thus: "We, the American Tinplate Company, parties of the first part, and the Tinplate Workers' International Protective Association of America," parties of the second part, do hereby agree that in all mills recongised by the parties of the first part as nou oryanised the following scale of prices shall govern the wages of employees.' 3 Such was the situation when the United States Steel Corporation was formed, early in 1901.

Into the history of the formation of that gigantic capitalistic combination we camot now enter. It is enough to notice that it is the most stupendous example yet witnessed of a process which is probably going to transform more and more the organisation of industry

1 The benefits conferrcd upon society by the action at this time of the Carnegie management have been set forth with entire sincerity by Mr. Schwab on many occasions, before the Industrial Cummission and elsewhere, and his arguments are easily accessible; while a less optimistic view of the resulting situation will be found in a chapter in Mr. Spahr's America's Working People.

2 A branch of the Amalgamated Association. 'International,' in the titles of American trade unions, is intended to include Canada.

3 Text in Appendix VI. 4. 
--the process known as industrial 'integration:' the process, namely, of bringing under one ultimate control the whole series of operations in any particular field, from the secming of the raw material to the turning out of the finished product. Hitherto great undertakings have usually concerned themselves mainly with one or other end of the series of operations or with some intermediate phase. But, with the widening of the market, the representatives of the two ends are coming inevitably into conflict. The finished product people, to insure a supply of material at a price that -uits them, are more and more tempted to produce that material themselves, and so curtail the narket of the raw material producers. The raw material producers, on their side, are anxious to serure a steady demand for their output, and for this purpose are inclined themselves to work up their materials into finished goods. Naturally, in this general statement, 'materials' and 'finished goods' are only relaîive terms.

Now in the steel business there had come to be two sroups of weat consolidated companies-one, of which the Camegie Steel Company was far the greater, which produced steel billets, ingots, bars, plates, and slabs, all constituting the material for the second group of companies, which turned these billets \&c. into tubes, wire, tin-plate, sheets, structural material, and other relatively finished goods. And things had come to such a pass that each group was believing itself obliged to enter into the business of the other. ${ }^{1}$ An internecine conflict was imminent when the financial interests (which, for reasons I need not pause to explain, were at this time in control of most of the companies) inter-

1 The history of the matter is given by Mr. Meade in the Quarterly Journal of Economics for August 1901. 
vened and prevented the conflict by welding all the opposing interests into one great organisation-the United States Steel Corporation.

In this transaction the Carnegie Steel Company, which was best equipped for the struggle, had secured the best terms, and its manager, Mr. Schwab, was appointed President of the combination, which now included some 75 per cent. of all the steel interests of the country.

Into this combination had entered three of the great companies with which the Amalgamated Association of Iron and Steel Workers had been accustomed to 'sign' the annual 'scale.' The Amalgamated knew what the Carnegie Company's policy had been; and though the several constituent companies in the new corporation were left free to manage their business as before, the Amalgamated naturally dreaded the influence of example. They thought they had better take time by the forelork, and, before the Homestead influence should begin to deunionise the partially mionised subsidiary companies, make an effort to completely unionise them. Acordingly. when the time ame to sign the scale, e.\% with the Sheet Steel Company, they demanded that the scale should be signed for all the twenty-eight mills belonging to the company, and not for the twenty-one only which had hitherto been recognised as 'organised' or 'union;' and similar demands were made on the other companies. How far this demand agreed with the wishes of the men in the mills not previously recognised as 'union' it is hard to say. In some cases branch unions had secretly been formed in them; and the employers seemed to go so far as to say that it was a breach of faith when the men of a mill, not previously ' recognised' as 'union,' volun- 
tarily mionised themselves. In other ases it may be true that the demand of the Amalgamated was tantamount to rompelling the employers to coercively unionise a mill.' However, in the strike that followed, the Amalgamated was badly beaten. They had miscalculated the extent of their command over the labour market; they had exagserated the probable eflect of a prolonged strike upon the stock market. It was this last mon which they had counted; for sreat masses of the bonds of the companies were still in the hands of financiers. But the American people just at that time were rather proud of the Steel Corporation as the husest thing of its kind, and destined to rominate the world; and high prices for steel do not rome home to the masses like high prices of roal. There was no popular outcry and no panir in the money market, and the strike failed. It was never one for wages in the present, but arowedly one to compel complete 'recogntion' of the mion, and that only-so as to influence wages in the futme.

It has been several times pointed ont already that the combination of rapital farilitates the introdurtion and maintenance of the method of collertive bargaining or joint agreement-when rapital is ready to adopt it. It also, as this last example shows, enommously strengthens capital in its resistance, so long as it wishes to resist. We camnot expect so momentous an issue as the nature of the mechanism for the adjustment of wases to be determined without protracted conflict in a comntry where the individualist spirit in business, and therefore the monarchical spirit in business, is so strong as in the United States. The leading Imerican business men, however, are in their way

1 Cf. Talcott Williams in American Review of Reviews for September 1901. 
industrial statesmen. They will not be content simply to suppress unions again and again : they will seek an alternative policy. Mr. Schwab's own policy has just been announcel as one of profit-sharing; and he is now carrying through a scheme to facilitate the acquisition of stock in the Steel Corporation by the operatives employed. I am ready to confess that I am not absolutely sure he may not succeed thereby in killing unionism in his particular branch of trade. I hold no brief for unionism. It is not an end in itself, but only a means to an end; and the end or ends may conceivably be reached in other ways. But I doubt whether the management of the Steel Corporation realises the grave practical difficulties in the way of the permanent success of this alternative policy. The problem is one very larcely of business administration-how to deal. with least expenditure of time and energy, with large masses of men engaged in more or less similar work. Ind I should not be surprised if American business administrators, after desperately fighting unions until they are tired, should suddenly come to terms with the men, and organise 'joint agreements, with a completeness and with a thoronghness the work has never seen. The critic may object to such an allianre, and talk of the interests of the consumer. But we have so long idolised the consumer and with such unsatisfactory results, that society may do well to try the experiment of thinking first of the producers-of all the prodncers.

1 An abstract of the scheme is given in the Labour Gazette of the Board of Trade for February 1903. The plan provides (1) for the accuisition by cmployees of preferred stock, $(2)$ for the payment of an additional 'dividend' of 5 per cent. to empl wees who keep their stock, remain in the service of the corporation and 'show a proper interest in its welfare and progress,' (:) the parment of a still further dividend to employees who remain in service for five years and whom the corporation 'shall find deserving thereof.' 


\section{LECTURE TIII}

THE LEGAL POSITION OF TRADE CNIOXS

Thos: of you who have done me the honour to listen to the previous lectures of this course will have antiripated the conclusion: that the differences between the United States and Great Britain in the matter of the organisation of labour are differences of degree and not of kind. This is true of the whole of the industrial life of the two countries: and, when one stops to reflert, one sees that it must necessarily be so. Both are engaged in carring on large-scale production, with the assistance of modern marhinery; both exhibit that 'capitalism' which is the neressary result of modern mechanical methods; both are inhabited by peoples of the same stocks; both are self-governing republicsthe one of the Presidential and the other of the Cabinet type; and they share the same ideas of political and personal liberty. In certain deep fundamental traits, indeed, all countries resemble one another which have entered into the modern phase of capitalistic production; and Tokyo, Bombay, Lyons, Bradford, and Fall River present more than one identical problem. But between Great Britain and the United States the resemblance is peculiarly close, as may be illustrated by the fact that exactly what some English observers are saying just now of America, French observers, until recently, and some of them even now, have been saying of England. Both English observers of America and 
French observers of England are holding up the individual enterprise, the self-reliance, the energy and vigour of the observed country as examples for their own.

The differences of degree are not inconsiderable. The spirit of independence, readiness to look after one's own interests, readiness also to let other people take care of themselves, are undoubtedly more widely diffused in America than in England. The greater opportunity for individual advancement so often to be found; the fact that the population of the New World represents that part (or the descendants of that part) of the less comfortable classes in the Old World which had such exceptional enterprise that they tore themselves up from their old roots and crossed the Atlantic; the more abundant food enjoyed by the large body of the manual labouring class; the dryer, brighter, and more stimulating climate-all these, and a score of similar influences, have had their effect. And it is obvious that England, for good or for ill, is less completely defeudalised socially than America. America is a far less 'deferential ' country, to use Bagehot's phrase. On the political side this 'deference' has been, on the whole, hitherto a great advautage for England: it has left the administration mainly in the hands of 'the governing' classes,' though subject to the salutary check of a public opinion which prevents the grosser forms of corruption. But one set of consequences of such a state of mind cannot be enjoyed without another sot. And as 'deference' implies the recognition of differences of social status, it involves in industry a 'class-consciousness' which has greatly strengthened English unionism. All this is true; and yet how carefully all such statements need to be guarded will occur to us when we reflect 
that the Yorkshire or Northumberland miner, or the Lancashire operative, is hardly over-burdened with 'deference' in the usual sense of the word!

What, I think, we may fairly say is this. First, that the population of the United States is still far more agricultural and rural than that of England; and, in the smaller country towns, of which there are hundreds, the tone is set by the fairly comfortable, very independent, farming rlass, tilling their own land. In such towns unionism is probably weaker than in similar English localities. Such are the neighbourhoods, for instance, described by the lady of [owa who writes under the name of $\mathrm{O}$ (tave Thanet; and of its people her phrase 'the contented masses' is true enough.' Moreover, one cannot help, suspecting that in many of the smaller industries of England, whether in great towns or small, there still survives not a little of the old guild spirit in its later and more decadent aspect. And the mobility of American conditions will not suffer the prudent selfishness of a little stationary group. But when we pass from the mainly rural areas, or from those charming ' residential ' districts which are all that a travelling Englishman usually sees, to the great staple industries of the country-coal-mining, iron and steel working, the textile manufactures, \&c.-we come to conditions much more like those in this country. The fact is that when men are engaged in considerable numbers upon a comparatively few uniform operations, they must of necessity receive a more or less uniform treatment from their employers, and they inevitably tend (if they are men of European stock) towards a more or less formal unionism.

The moral of the trade union history of America

1 See her article in the Forum for October 1894. 
will be drawn differently by different observers. It may be said, with perfect truth, that unions have never yet succeeded in America in maintaining for any considerable period their influence and numbers. Their story has been that of one great wave after another, each breaking soon after it has reached a head. But I cannot help thinking that with the filling-up of the country, and the lessening of the opportunities for individual advancement, there has been a distinct progress on the whole towards a more permanent solidarity. The history of the efforts towards the unification of labour may suggest, it is true, the very same conclusion as the repeated failures to unify capital led to in the ante-trust days-the conclusion, for instance, that M. Paul de Rousiers reached with regard to the anthracite operators as lately as 1896 , i.e. that they were always destined to ill-success. ${ }^{1}$ But, as the successive capitalistic combinations are now seen each to have represented a stage towards a more permanently unified control, so, with graver difficulties to contend with, the consolidation of labour has nevertheless made considerable headway. One should not prophesy unless one knows; and it is conceivable, as I have before said, that a gigantic counter-policy of labour-partnership, such as the Steel Corporation seems about to initiate, may so conciliate the workpeople that labour unions will no longer be maintained. But I doubt whether such a counter-policy is sufficiently in keeping with the democratic temper to be permanently successful, and, moreover, whether it does not require more continuous prosperity on the part of the Corporation than can be reasonably counted upon. And, if this is so, the only alternative to mionist

1 Les Industries Monopolisées aux États-Unis, 125. 
co-operation in the management of industrial life would seem to be State control. Meanwhile the striking similarity between the tendency everywhere in England, in the industries we have examined, towards 'collective bargaining,' and in America towards 'joint agreement' - the tendency in each country a spontaneous and independent one, and certainly not merely imitative -is surely impressive to the neutral spectator.

In the short time that now remains to me, I want to call your attention to the question of the legal position of mions, and especially to the bearing of that question on the proposal to give joint agreements or collective bargaius a legal validity enforceable by process of law. 'Those of you who hare studied the history of political theory will remember the way in which great ideas, such as the divine right of kings or the sovereignty of the people, make their appearance from time to time in the most diverse contexts, and as theoretical justification for very widely diflerent parties. It is much the same in the listory of economic ideas: 'laissez faire,' for instance, is at one time the gospel of 'Liberalism,' and at another time the creed of 'Conservatism.' The particular topic before us furnishes an example of the same piquant juxtaposition of opposites.

During the recent anthracite coal strike in America it was again and again urged by the operators that, if the miners' mion wished them to enter into a joint agreement with it, it ought to become incorporated and so capable of entering into an enforceable contract. Thus one operator replied to Mr. Mitchell's invitation to a conference that he 'questioned whether the method of conlucting the aflairs of the company would be improved by entering into arrangements which do not 
have the legal quality of contracts;' while another declared that "until the umion assumes some legal and pecuniary responsibility, no contract would be of any avail.' Mr. Wright was so impressed by these contentions that, in his report to the President, to his 'suggestion' that the anthracite miners shonld form a separate union of their own, he added the clause, ' and be financially responsible for its agreements.'

This report has concentrated attention in America upon a proposal which hitherto no one perhaps had taken very seriously: the proposal that unions should be incorporated. The state of the law is apparently very much what it is in England : unions have refrained from becoming incorporated because they did not wish to be. Things are a little different in that, in several states, the incorporation of trade unions is expressly permitted by statute, ${ }^{2}$ and a federal law authorises the incorporation of national unions. ${ }^{3}$ In the state of New York a number of unions have actually incorporated themselves. ${ }^{4}$ But the stronger trade unions have almost all refused to avail themselves of the opportunity. Before 1902 there was, indeed, some division of opinion on the subject among labour leaders. Two or three of the heads of very important unions regarded incorporation as in itself desirable, e.g. the president of the Cigar Makers' Union ${ }^{5}$ (with some 27,000 members), and the president of the Amalgamated Association of Iron, Steel, and Tin Workers. Said the latter in 1899 before the Industrial Commission, 'I hope thie time will come when the Amalgamated Association will be able to take ont

${ }^{1}$ Bulletin 43 of the U.S. Department of Labor (November 1902), $1175,1212,1166$. The more important passages in Mr. Wright's Report are printed in the Appendix IV. 5.
"Rep. Ind. Com. xvii. 616 seq.
${ }^{4}$ Ibid. vii. Digest, 106.
3 Text, izid. v. 126.
s Ibid. vii. 172 . 
letters of incorporation and become a chartered institution.' But he would not. he went on to say, advise it until his men were ready, and they were not ready yet. They had not yet completely learnt the lesson of discipline and obedience to the constitution of the union, and some of them still indulged in unauthorised strikes. ${ }^{1}$ But most labour leaders were not so favourable to incorporation even as this. Their state of mind is well expressed in the evidence before the Commission of Mr. Compers, the President of the American Federation of Labor, in the same year, 1899. He did not believe that a contract could be practically enforced by legal proceedings against an employer who sought to evade it; the only way to enforce it was 'by the power of the organisation '-i.e. by a threatened strike; and if a union was strong enough to bring an employer to terms, it did not need to be incorporated or make a formal agreement. ${ }^{2}$

Confronted anew in 1902 with the demand that unions should incorporate themselves, 'organised labour' saw in it only a device of the enemy, and would have nothing to do with the proposal. ${ }^{3}$ Some outside impartial observers, also, felt that the call for trade-union incorporation was at any rate premature.

1 Rep. Ind. Com. vii. 388.

2 Ibid. vii. 601 4. The president of an American union holds practically much the same position as the secretary of an English union.

3 'It is, indeed, strange how many gentlemen are solicitous for the trades union to become incorporated, and to be placed within what they called the purview of the law, in order that it nay be mulcted in damages for any suit that may be brought against the organisation. We leave out the opportunity for harassing the union by interminable lawsuits. And besides this, the union attacked from any and from all sides would be in constant litigation, and it is unquestioned that our organisations could not attempt to retain counsel, either in numbers or in talent, comparable to the counsel which is always at the command of wealthy concerns.'--Mr. Gompers at the Industrial Conference held under the auspices of the National Civic Federation, Deccmber 1902, Report 262. 
Incorporation, with the consequent power over the unions of the law courts, would, they thought, frighten multitudes of men from joining the labour organisations. And Mr. Graham Brooks urged with much force that the method of voluntary joint agreement had an educational value such as belonged to no compulsory observance of a contract. ${ }^{1}$ But the most forcible utterance was that of Senator Hanna, at the December (1902) Conference of the Civic Federation. Senator Hanna, the chief manager of the Republican machine, is certainly the most important among the men, other than the President, who are in public life at the present day in the United States. He is also a large capitalist, and a man of considerable business experience. To many of my 'mugwump' friends in the United States he is the incarnation of all evil; and it is open to anyone to believe that, in saying what $I$ am now going to quote, he was thinking only of gaining votes. But I take the liberty of believing that Senator Hanna was sincere in what he said. His point was that the unions-he was thinking of the great unions, and especially of that of the miners-could, on the whole, be trusted to carry out any agreements they made. I make no apology for quoting the passage, especially as it incidentally carries down the history of the United Mine Workers a stage later than I have hitherto brought it.

'In the discussion during the great coal strike . . . I heard the argument that it was an absolute necessity that incorporation must be had, because a contract with working-men was worthless. The test has come; for when, in their dire extremity, the anthracite miners of Pennsylvania appealed to their fellows in the bitu-

1 Report of Conference of Civic Federation (1902), 352. 
minous fields in the West to come out and strike in sympathy, in order that comditions might be forced upon this country which would conforce a settlement of the trouble, it is known to many other's that the bituminous coal miners thus appealed 10 were under contract for a year, known as the Interstate Contract, between the producers and the operators of those sections of the country. Under the constitution of the United Mine Workers it hecame the duty of their presickent to all together a clelegates "onvention to act upon that question. Those of us who had followed this trouble from the begimning with interest and anxiety felt that it was an important moment in the history of the labour question as to how that would be settled. For my part I had confidence as to the outcome. The convention met at Indianapolis, represented by persons or proxies of 1,000 delegates: and the appeal was made coming from the striking miners of the antluracite region to their fellow-workmen under most distressing circumstances and conditions, under influences which are so potent among that class-brotherhood sympathy. That convention appointed a committee of twenty-three to consider the application. They spent nearly a whole night considering it; they were confronted with the fact that they had made a contract with their employers, which for the fourth time had been made, to work for a scale agreed upon, to be in operation for one year, upon which the sales of coal were made and contracts binding upon the operators were made. After full consideration, allowing sentiment to play its part upon the minds and hearts of those men, with calm, cool judgment and loyalty to their agreement, that committee reported unanimously against a sympathetic strike. . . . That report was made to that convention the day fol- 
lowing, and was adopted unanimously by 1,000 votes. They agreed to stand by the word they had given in making that contract.

'Now, gentlemen, that case came up at a time when all the conditions surrounding it were as aggravating and forcible as could be brought into play. Therefore I say that the test has come, and the men have won the confidence of the whole people of this country, and, as far as I am concerned, satisfied me that we want no incorporation of labour organisations.' ${ }^{\prime}$

I must now ask you to return to England and to go back a few years, to the Report of the Royal Commission on Labour in 1894. That report stated that at present 'collective agreements are, as a matter of fact, frequently made between great bodies of organised workmen and employers, which bodies have no legal personality and cannot sue or be sued for damages occasioned by the breach of such agreements.' Under these circumstances, eight out of the nineteen members of the Commission united in representing that, in their opinion, the state of things thus described might be beneficially altered by some amendments of the existing law, such as would enable industrial associations (whether of employers or employed) to enter into legal contracts.'

The minority so recommending consisted of five great employers of labour, the Duke of Devonshire (chairman), Sir David Dale, and Messrs. Ismay, Livesey, and Tunstill; two politician-economists, Sir Michael Hicks-Beach and Mr. Leonard Courtney; and a distinguished jurist, Sir Frederick Pollock. And two things must be noticed with regard to their proposal : (1) that it did not propose compulsory incorporation; and (2)

1 Report of Conference, 365. 
that it recommended incorporation only for the purpose of enforcing collective agreements. Their language was as follows:

' In order to enable trade associations to enter into collective legally binding agreements, with the consequence that in case of breach of contract they would be liable to be sued for damages payable out of their collective funds, it would not be sufficient to repeal subsection 4 of section 4 of the Act of 1871.' (To this subsection we shall return later.) 'Even if that legislative incapacity were taken away, the trade associations would be prevented by their want of legal personality from entering into such agreements, or suing or being sued, except in regard to the management of their funds and real estate. It would be necessary that they should acquire by some process of registration a corporate character sufficient for these purposes. We are anxious to make it clear that we propose nothing of a compulsory character, but that we merely desire that existing or future trade associations should have the liberty, if they desire it, of acquiring a larger legal personality and corporate character than that which they can at present possess.'

And, again, with regard to agreements to submit to arbitration, they speak of the advantage of 'putting it within the power of such bodies to acquire legal personality sufficient to enable them to enter into collective agreements with the legal sanction of collective liability in damages.'

It is clearly implied in the words italicised that these new powers could be limited to the required purposes, and need not involve complete incorporation. ${ }^{1}$

1 Fifth and Final Report, Royal Commission on Labour, 116, 118. The signatories did not press for early action: "The evidence does not 
The four unionist members of the Commission (Messrs. Abraham, Austin, Mawdsley, and Mann), in their dissenting minority report, did not come to close quarters with the proposal as thus expressly limited. They denounced the much wider proposal that trade unions should all be compulsorily made legally responsible as corporate bodies for all the actions of their agents. Their representations run thus :

' One proposal made to the Commission by several witnesses appears to us open to the gravest objection. This suggestion is that it would be desirable to make trade unions liable to be sued by any person who had a grievance against the action of their officers or agents. To expose the large amalgamated societies of the country with their accumulated funds, sometimes reaching a quarter of a million sterling, to be sued for damages by any employer in any part of the country, or by any discontented member or nonunionist, for the action of some branch secretary or delegate, would be a great injustice. If every trade union were liable to be perpetually harassed by actions at law on account of the doings of individual members; if trade-union funds were to be depleted by lawyers' fees and costs, if not even by damages or fines, it would go far to make trade unionism impossible for any but the most prosperous and experienced artisans.

The present freedom of trade unions from any interference by the courts of law-anomalous as it may appear to lawyers-was, after prolonged struggle and parliamentary agitation, conceded in 1871, and finally

show that public opinion is as yet ripe for the changes in the legal status of trade associations which we have suggested; but we hare thought it to be desirable to indicate what may ultimately prove to be the most natural solution,' \&c.-Ibid. 119. 
became law in 1876. Any attempt to revoke this hardly won charter of trade-union freedom, or in any way to tamper with the purely voluntary character of their associations, would, in our opinion, provoke the most embittered resistance from the whole body of trade unionists, and would, we think, be undesirable from every point of view.'

No legislation has taken place since 1894 in England to realise the moderate desires of the Duke of Devonshire and his fellow-signatories, or to arouse the alarm of Mr. Abraham and his three unionist. colleagues. But far-reaching changes have taken place since then in the common law as defined by judicial decision, to which we must soon revert. Meanwhile observe that in 1894 it was the opinion apparently of all the members of the Commission that no suit of any lind could be brought aquinst a trade union as such.

Before, however, looking more closely into the legal revolution that has since taken place, let me introduce parenthetically a chapter of trade-union legislation from another quarter of the globe, from Australasia. Hitherto we have seen the proposal for more or less complete incorporation of unions proceeding usually from the capitalist or non-labour side, and resisted strenuously by the great body of unionist opinion. We have now to see it as part of a system of 'progressive labour legislation,' carried with the enthusiastic support of the unionists themselves.

The recent compulsory arbitration legislation of New Zealand and New South Wales covers a very wide field, and I do not propose to enter upon its discussion. It may be enough for me to express my

1 Fifth and Final Report, Royal Commission on Labour, 146. 
opinion; firstly, that such measures are more likely to be practicable in comparatively small communities, possessing the social characteristics of the Australasian States, than might be concluded from a statement of the theoretical difficulties in the way of their success; and secondly, that the fact that they are there successful, if it be the case, while it commends them to our respectful examination, by no means proves that the difficulties in a country like Great Britain (let alone the United States) could be overcome with equal ease. The one feature of the legislation which I want to single out is that which concerns the incorporation of unions. Both in New Zealand and in New South Wales the intention of the legislators has been to secure (among others) the particular advantage desired by the Duke of Devonshire and his associates, without subjecting the unions to the risks dreaded by Mr. Abraham and his colleagues. It was desired to make the unions corporate bodies, so that their funds could be reached for disobedience to the award of the court of arbitration or failure to carry out a collective bargain authorised by the court. It was anticipated that the measure would greatly diminish the number of strikes; and such has, as a matter of fact, been its result in New Zealand. But inasmuch as the court could only prescribe the terms on which labour should be engaged if the employer wished to engage it, and could not compel him to continue any particular business, it similarly could only prescribe the minimum wages the men should accept, and could not order men to serve for them. Accordingly, where there was no formal collective bargain, the men could not be prevented from striking to get higher wages than the court awarded, after duly waiting for the award. Hence the 
unionists were anxious to effect no change in what they supposed the existing law with regard to the legal responsibility of the union (e.g. for picketing). Accordingly the Acts, both of New Zealand and New South Wales, expressly enacted, in the most definite language that could be selected, that the legal incorporation which they conferred should be limited in its consequences to the purposes of the arbitration provisions. The clause in the New Zealand Act rums:

'Every society registered as an industrial union sleall, as from the date of registration, but solely for the purposes of this Act, become a body rorporate by the registered name, having perpetual succession and a common seal, until the registration is cancelled as hereinafter provided.'

The New South Wales Act is even more cautious :

- Upon the issue of a certificate of incorporation, the members for the time being of the company, association, trade union, or branch incorporated in the industrial union, shall, until the registration and incorporation of the union is cancelled in pursuance of the Act, be, for the purposes of this Act, a body corporate by the name mentioned in such certificate, and shall have, for the purposes of this Act, perpetual succession and a common seal.

'An industrial union may purchase, take on lease, hold, sell, lease, mortgage, exchange, and otherwise own, possess, and deal with any real or personal property: Provided that nothing in this sct shall render an industrial union liable to be sued, or the property of an industrial union, or of any member thereof, liable to be taken in execution by any process in law other than in pursuance of this Act or in respect of obligations incurred

1 New Zealand. Act of 1900, No. 51, \$7. 
in the exercise of rights and powers conferred by this Act.' 1

The intention of this clause was thus stated by the Attorney-General of New South Wales in moving the second reading of the bill: 'A trade union, by applying to be registered as an industrial union, acquires a legal personality only for the purpose of making a collective bargain.' 2

The remarkable thing is that at the very time the Attorney-General of New South Wales was thus speaking, the legal position of trade unions was being fundamentally changed in England by the decision in the Taff Vale case. It had been assumed all round that trade unions could not be sued in England, since they possessed no corporate capacity, and unionists had fought shy of proposals to give them more of a corporate capacity lest it should involve liability to legal action. It was now held that, without any legislative change at all, unions could be sued in their registered names by way of an action in tort.

The history of the Taff Vale case is a striking example of the uncertainty of our law. In 1900 it was held by Mr. Justice Farwell that a trade union was suable in tort. In 1901 his order was unanimously set aside by the Court of Appeal, consisting of three judges presided over by that eminent lawyer, the late Sir Archibald Smith, the Master of the Rolls. Two or three months later it was restored with equal unanimity by the House of Lords, the court consisting of the Lord Chancellor and four law lords; and it is now the law of the land. It was no brutum fulmen. At the end of 1902 a verdict was given by a London jury, directed by

1 New South Wales, Act No. 59, 1901, §7 (1) and 7 (2) (a).

2 Speech of July 4, 1900. 
Mr. Justice Wills, against the Amalgamated Society of Railway Servants, in an action for damages due to the Taff Vale Railway Company, for having carried out the strike of 1900 in unlawful ways. The damages claimed were $£ 26,626$; and, before the judge could assess the amount, the union thought it wise to agree to a settlement by paying down the sum of $£ 23,000$. Little wonder that all the trade unions of England are greatly perturbed.

As to the original Tatf Vale decisions of 1900-1901 I cannot but think that the honours of the controversy were about equally divided. From a purely historical point of view, considering the form of the Act of 1871 and the circumstances of its origin, I must confess that the argument of the Master of the Rolls seems to me unanswerable. From the point of view of sheer logicality, the same is to be said, I think, for the arguments of Mr. Justice Farwell and the Law Lords. For once logic triumphed, almost ostentatiously one may say, over history.

It is easy to attribute the Taff Vale judgment of the Lords to unconscious class bias. Whether there was bias or no I do not feel qualified to pronounce. But the logicality of the judgment is now recognised even by the eminent counsel whose business it was to maintain the opposite before the court, and it seems to commend itself generally to the legal profession. It must be noticed that circumstances had for some time been breaking down the old sharp distinction between corporations and individuals. All sorts of associations had been forming themselves (e.g. clubs), which practically exercised the functions of corporations, and therefore had to be subjected to the legal liabilities of corporations, whether they were called corporations or 
no. The matter has, indeed, of late been the subject of much discussion among jurists of a philosophical turn in several countries. ${ }^{1}$ Some of the law lords were careful to say that, in spite of its liability to be sued, a trade union was still 'neither a corporation, nor an individual, nor a partnership between a number of individuals.' But Lord Brampton, less careful in his language, summed up the situation in the following remarkable words: 'I think that a legal entity was created under the Trade Union Act of 1871 by the registration of the society under its present name . . . and that the legal entity so created, though not perhaps in the strict sense a corporation, is nevertheless a newly created corporate body . . . distinct from the unincorporated trade union, consisting of many thousands of separate individuals, which no longer exists under any other name.' This obiter dictum is not yet law ; meanwhile a 'corporate body' which is not a 'corporation' may be commended to the attention of the lawyers.

It would be rash after so many surprises for one to say what a union cannot now do or be done to. The Taff Vale decision was limited to the liability of a union for tort, and Mr. Justice Farwell implied that the Act of 1871 would prevent a suit for breach of contract. The Act of 1871 expressly lays down that a union shall not be liable for the breach of any one of a number of specified agreements, and among them is 'any agreement between one trade union and another.' The same statute defines a trade union in a way which seems (I say seems) to include a union of employers; and so the Duke of Devonshire and his associates in 1894 thought the Act would prevent the enforcement of

1 See Professor Maitland's Introduction to his translation of Gierke's Political Theories (1900). 
a collective bargain. But such a bargain is not expressly taken out of the category of enforceable contracts. Moreover. this year Mr. Justice Grantham has held in the Inenuly ruse that a nember of a union an obtain an injunction against the society to prevent the spending of its funds contrary to its rules. on the wound that membership moler the lules involves a contract which can be enforced, in spite of what seemed the clear intent of the Act. The matter has been appealed. and we must wait for the final decision. But my point is this-and $I$ am afraid you will think I have taken a long time to come to itthat the Taff Tale decision has removed from English unions their rhief reason for declining to assume a corporate rharacter for the purposes of collective agreements. They are already subjert. by the Taff Vale derision, to the liabilities which they thonght to avoid: and now that they wan be sued, whether they are incorporated or not. they have no particular reason to remain mincorporated.

The law. as stated in the Tafl' Tale "ase, is pretty certain to remain for the future: and unions will in future be responsible for the wrongful acts of their representatives. The real question which demands an answer is, what are wrongful acts: I shall not attempt to disentangle the complexity of the present legal position as formulated in the decisions of the last three or four rears. Eminent lawyers are still capable, in the interest of their clients, of making laree and positive assertions in court: but they know very well that in reality the law is at present in a state of creat obscurity and uncertainty. It is an actionable offence to maliciously induce a person to break a contract. Granted. But what is malice? It is not easy to see how the decision 
of the law lords in the Irish case of Quinn v. Leathem can be reconciled with the more recent decision of Mr. Justice Bigham in the so-called Stop-day case. In each case a breach of contract was induced-in the former, in order to unionise a shop, in the latter in order to keep up the price of coal. Both purposes are quite natural objects for trade unions to pursue. I am not saying that there was no distinction, but that the distinction camnot be found in any compendious definition of 'malice,' but must be found, if at all, in circumstances which the courts have not yet analysed. Then take the matter of picketing. There is a great deal of unreality in the language people use on this subject, and I am bound to say trade unionists are not free from it. We had better recognise at once that picketing is a form of suasion which is necessarily bound up with an implied threat of as much social excommunication as the union can prorure. The distinction between physical violence and sorial excommunication is a tolerably clear one. The former can be provided against by law : the only provision that I can see against the latter is the support of the employer and a stout heart. Certainly the distinction in Lyons $\mathrm{r}$. Wilkins in 1890 between 'besetting for the purpose merely of 'communicating information ' (which was held to be legal) and besetting' for the purpose of "persuading "men not to work for an employer (which was held to be illegal) is too subtle a one for the workaday world-to say nothing of the doubtful justice of penalising mere 'persuasion.'

Furthermore, even if the offences were clear, the law of agency is not; and it is surprising that lawyers do not more generally realise this difficulty. An agent is only acting as agent when he is acting within the scope or range of his emplorment. But 
in most cases it is clear when he is within that sphere. The coachman who inrolves his master in damages when he runs over a person, even in spite of his master's warning-the example sometimes given in this comnection-is at any rate engaged in driving his master's carriage. But if he goes out bicycling for his own pleasure and runs orer some one, his employer is not responsible. It will not always be equally easy to decide whether. when A. 13. tells a crroup of workmen that they ought to do this or that, he is acting as an official of a union or as a private person with a right to an opinion of his ow!. The Bill just introduced into Parliament by the unionists, which would exempt the union from responsibility for acts done without " the directly expressed sanction or authority of the rule of such mion,' does not meet the case. Unionists, though as honest as other men, follow the adrice of their lawyers, and they would naturally be adrised to make their rules as reticent and non-committal as possible. We must leave it to the judge, it seems to me, to determine whether in particular instances the officer of the mion was really acting as its agent or not. Yet this may involve an intimate knowledge of unionism, such as possibly all judges do not at present possess.

For these reasons I agree with those who urge that before proceeding to further legislation it is expedient that the rhole question should be first considered by a small commission of legal and administrative experts. I would only add that it will be quite necessary for such a commission to flankly take into their consideration modern industrial conditions and the natural purposes of trade combinations. This has already been done to some extent with regard to capitalistic combinations, in the case of the Mogul Steamslip, Company in 
1892: a case which has made a vast breach in the old law of conspiracy as previously understood, and which most American lawyers still regard with bewilderment. But the process will have to be carried further. I do not say that the Moyul decision is verbally inconsistent with the trade-mion decisions; but I should like to have its inner economic consistency with them examined by competent critics. And it would not be surprising if the outcome of the work of such a commission were to compel our courts to enter more than they have hitherto done into the actual constitution and character of the unions which come before them. This is what the Australasian courts of arbitration are doing, in determining whether such and such demands are justifiable; and their action seems to commend itself to Australasian common sense. But, of course, such a task will be far more difficult here.

Meanwhile of the recent legal decisions it may be said with some confidence that, while they will weaken weak unions, they will strengthen strong unions. Weak unions are more apt to make use of picketing; and weak mions can least aflord the expense of litigation. But the great societies will be maffected by much of the recent judicial legislation, or affected only in the direction of greater internal consolidation. Associations, like those of the miners and the cotton operatives, where practically all the people employed are in the union and form the bulk of the population in particular districts, do not need to resort to picketing. It has been said that the new legal liability for the acts of agents will compel the unions to completely separate their friendly benefit fund from their strike fund. It is not clear that it will be altogether the case; for the unions must still retain, for purely trade purposes 
(such as out-of-work donation), funds, other than those provided for strike contingencies, which will be quite considerable in amount. In any case it may be observed that the miners' mions do not usually carry on friendly society functions to any large extent; that is done, in the mining districts, by separate organisations. If some unions are actually led to surrender their friendly society functions, it is not certain that the effect will be a soothing and quieting one. Whether unions should exercise friendly society functions or not has often been a moot point in trade-union policy. If such functions help to bring in members and keep them in, they also make the society more cautious: it is stronger when it wants to fight but less disposed to fight. The recent history of unionism among English miners would not, one would suppose, lead coalowners to regard the absence of friendly society functions as necessarily a merit in trade mions.

What we may expect to be most marked will be the effect of recent decisions in promoting wreater consolidation, unity, diseipline, within the mions. We all know now, for instance, that the 'Tan' Vale strike was undertaken in spite of the advice of the general secretary, and that his hand, and the hands of the society, were forced by one of the inferior officers who 'acted directly contrary to the rules and instructions of the Executive Council.' The result of the recent verdict has been a resolution which will in future subject the inferior officers more directly to the general secretary. And, again, in the recent Denaby case, it is pretty clear that the central executive was afraid to enforce the Federation's own rules against an important local branch which wanted to strike. If Mr. Justice Grantham's decision should be confirmed,-that, in such 
a case, any individual member can sue the union for

a breach of the contract implied in the rules,- - the union executive will be supplied with a new and powerful argument why the men should abide by the constitution they have themselves set up.

I cannot conclude without thanking you for the attention with which so many members of the University have listened to what I have had to say. I have felt the great responsibility of the opportunity, and I can only hope that you will allow that I have endeavoured to be impartial. These are only the provisional conclusions of one who has tried to take a general view of a very wide subject. You will not think of them as 'ex cathedra' pronouncements, but as a preliminary survey of a field of investigation on which I trust some of you will enter for yourselves. It is twoand-twenty years since I heard Toynbee lecture in this University on the work of Boards of Conciliation. If a comparison of the situation then and now is not altogether encouraging, it does show that the world has been moving; and if I have not used in this course the language of economic ethics, it is because I think the greater need of our own day is for absolutely colourless economic dynamics. Before we set about judging the forces at work, we have to learn what they are. 


\section{APPENDIX}

\section{COAL MINING IN GREAT BRITAIN : SOURCES OF INFORMA'TION.}

1. Official Statistics. - Of these the best known are those to be found in the General Report and Statistics: Mines and Quarries, issued annually by the Mine Inspection Department of the Home Office. This appears now in three parts. The first, entitled District Statistics, presents the figures, as the introduction apologetically remarks, in a form 'governed by administrative arrangements.' The information is arranged under the heads of the statutes empowering inspection-the Coal Mines Regulation Acts, the Metalliferous Mines Regulation Act and the Quarries Actas well of the twelve inspection districts, which have only a very loose connection with the real geography of the trade, so that for purposes of social enquiry the figures are almost valueless. Part II. Labour, edited by Dr. Le Neve Foster, is more useful. It classifies the mines not accnrding to Acts of Parliament, but according to the different kinds of minerals worked, and arranges the figures not according to artificial districts but according to natural divisions, such as coal fields. Here then will be found the number of persons employed in each of the great coal fields, classified according to sex and age and employment, above ground and under; together with all the figures as to accidents, prosecutions, and a good deal of miscellaneous information, e.g. with regard to the use of mechanical coal cutters. Part III. Output, gives for coal the output classified according to counties and chief coal fields, and the average 
price per ton at the pit's mouth. In one important table it gives the total output for the last twenty-nine years, the amount exported, the quantity remaining for home consumption and its proportion per head of the population-figures not directly pertinent to our particular enquiry, but of the utmost interest in relation to the duration of British coal supplies. In another are given the average prices at the pit's mouth, in the London market, and at the principal shipping ports for the same period; and a series of other tables give the amount of coal conveyed by the several railways and canals, the amounts shipped coastwise and exported from the several ports, and the quantities exported, with declared value, to each foreign country. These figures are as well presented as is perhaps possible with the present returns; the chief among them are probably as accurate as can be obtained; and the statistical work of the Department seems to deserve the high esteem in which it is held by mining authorities. If any suggestion might be ventured it is that we should be given a table showing output and number employed in each of the districts which go to make up ' the principal coal fields.' 'The 'Northern Coal Field,' for instance, is a natural unit, lying in one great mass, while the 'Midland Coal Fields' include several distinct and geographically separate areas, e.g. North Staffordshire and South Staffordshire, which are in some respects very different. It must be added that for the employment of the figures for any but the very broadest considerations a good deal of linowledge of the peculiarities of the several districts is indispensable.

Of more direct importance for our immediate purpose are the publications of the Board of Trade concerning wages, hours, and organisation of labour. Much of this information appears first in the monthly Labour Gazette. It is then brought together by the Labour Department, and presented in a corrected form in a number of annual volumes. There are (1) the Report on Trade Unions, issued annually; (2) the Report on Strikes and Lockouts during each year ; (3) The Report on Changes in Rates of Wages and Hours of Labour during each year.

These are all boiled down, together with the like annual 
volumes on Co-operative and Friendly Societies, and a vast amount of other information, and the totals put together in a fourth annual publication, the Abstract of Labour Statistics. But this does not exhaust the number of publications of the Board of Trade which the student is bound to attend to. Two important Reports were issued in 1900 (in continuance of previous Reports of 1894), one on Standard Piece Rates of Wages and Sliding Scales in the United Kingdom, and one on Standard Time Rates of Wages. I fail to see any sufficient reason why these should have been published apart from one another, especially as the most important tables as to the rariations in the great piece-working trades-coal and cotton-appear in the Appendix not to the Piece Piate but to the Time Pate volume. From time to time the Department also issues a Directory of Industrial Associations in the U.T. Nor must one neglect the Annual Report by the Board of Trade to the Honse of Commons (the others are technically Reports to both Houses of Parliament) on Procecdings under the Conciliation Act of 1896. This list is a fair sample of the piecemeal way in which our administrative services, and the statistics they produce, have come into existence. The British public proceeds by a series of happy thoughts- 'Happy Thought. Let's have the statisties of Trade Unions'- 'Happy Thought. Let's have the statistics of strikes,'\&c.; and each means a separate publication. I cannot but think that the time has come for the collection of most of this information, so far as it relates to conditions of employment, into one well-digested annual volume. But it should be added that so far as I can see there is no basis at all for the charge of partiality to labour which has been brought against the Labour Department. The criticism the student of social aftairs has to bring is that the Department is only too anxious to reduce everything to tabular figures, and that when it does devote a paragraph to any particular labour difficulty of the year it confines itself so very cautiously to the alleged causes of the dispute and to the bare external facts of the settlement, without entering into the merits of the case on either side. But that is only to say that it remains within the proper 
limits of a Government Department. It should not be necessary to add that only the very largest and broadest facts presented by the Department's statistics can be safely employed as indications of industrial tendencies. The particular figures require for their interpretation a great deal of knowledge of the circumstances of the trade or district concerned, and indeed are chiefly valuable as statistical measurements of conditions otherwise ascertained.

2. Turning next to governmental publications of a nonstatistical character, there is the great 'corpus' of evidence before the Royal Labour Commission, whose first thick volume in group $\mathrm{A}$, issued in 1892, and a part of the second, are taken up by mining. The conclusions of the majority of the Commissioners on Wages Boards and Sliding Scales are briefly set forth in three pages in the final report issued in 1894. The rules of a considerable number of employees' and employers' associations are given in a tabulated form in a separate volume, Rules of Associations of Employers and Employed (1892). The whole collection was supplied with an elaborate digest of evidence, on a scale more liberal than in any previous Royal Commission. But it is significant of the state of economic studies that, so far as I know, no attempt has ever been made to gather out of all this mass of information the more considerable and significant facts as they concern any one of the great staple industries of the country, and put them together in an interesting form for the general public. There is still nothing for it but to wade through the evidence itself.

3. We now come to non-governmental publications, and in the first place those which have to do with general mining conditions. (a) As to the probable mineral resources of the several fields, there is still nothing better than the work of Dr. Edward Hull, late Director of the Geological Survey of Ireland, on The Coal Fields of Great Britain, which appeared first in 1861, and of which the fourth and last edition was issued twenty years later in 1881 . The veteran geologist has set forth his later opinions in a little supplementary work-Our Coal Resources at the Close of the XIX. Century-in 1897; and it is a matter of satisfaction that after having been a chief 
contributor to the discussion at the time of the first Royal Commission on Coal Supplies between 1866 and 1871, Dr. Hull should himself take a place in the Commission on the same subject appointed on the last day of 1901. To these works may now be added The Coal Fields of Scotland, by R. W. Dron, 1893. (b) The last attempt to describe the several coal fields in a systematic way in relation to kinds of coal produced, modes of working, numbers and terms of employment, \&c., was made as long ago as 1882 by $\mathrm{Mr}$. Richard Meade, then Assistant-Keeper of Mining Records, in his Coal and Iron Industries of the United Kingdom. For developments since then the investigator must turn to the columns of the great trade journals, such as the Colliery Guardian and the Iron and Coal Trades Review. These print a large number of the more important papers read before mining and engineering institutes ; and the chief annual statistics and some of the most valuable of the papers appear in the handy and inexpensive little yearly volume-the Colliery Managers' Pocket Book, published by the Colliery Guardian. On all labour subjects the trade journals naturally take what may be called a moderate employer's view. On Colliery Working and Management, including the control and remuneration of labour from the colliery manager's point of view, we are fortunate in possessing a recent (1896) authoritative treatise by Mr. Bulman and my colleague at Birmingham, Professor Redmayne, who, before he condescended to acadenic life, was manager of the well-known Seaton Delaval Colliery in Northumberland.

Reaching at last the sources of information which deal especially with the conditions of labour, we have to distinguish between the official publications of associations of employers and employed, and of Conciliation Boards and the like, and the private publications of individuals.

In the first class are the Rules of Associations, the Constitutions of Boards of Conciliation and the like. These are not always easy to obtain from the secretaries. They are not regularly published and offered for sale; and, with the best will in the world, the secretaries do not always have a supply of them on hand to meet the requirements of the 
economic investigator. The secretaries and other officials are always desperately busy with the immediate concerns of the moment, and have not time to provide the inquirer with historical material. But it should be one of the functions of the economic library of a university to keep in touch with the secretaries of the important organisations, to secure their current documents, and to file and bind them systematically for future reference. Fortunately some of the most important documents have been printed in the appendices to the Labour Commission's volumes, other's in the publications of the Labour Department already referred to, and others in various private works.

The printed material most valuable for the economic investigator is, however, often of a semi-confidential character. This is true, for instance, of the Monthly Circulars of the Durham and Northumberland miners and the Annual Reports of the Yorkshire Association. But having been allowed to read through several such documents, I fail to see how the unions conld be injured by the widest publicity. It would be wise, I should think, to publish such reports in the nsual way, so that any interested person might buy them without troubling the secretaries. This observation does not apply, however, to the shorthand Reports of Proccedings before Conciliation Boards. These boards would lose much of their efticiency if the speakers were conscious that every impatient word, every slip of grammar, was to be criticised by the cold outsider. The officers of such boards will, however, always use their discretion in allowing access to these minutes to economic investigators, and I trust they will find I have not abused their confidence.

Among the private works the first place must be given for several reasons to the three modest papers of the late Professor Munro of Owens College, entitled Sliding Scales in the Coal Industry, 1885, Sliding Scales in the Iron Industry, 1885 also, and Sliding Scales in the Coal and Iron Industries from 1885 to 1889 . This was the first attempt by an economist to make a systematic collection of data, and to comment on their significance. His brief observations are still among the very best characterisations of the merits and demerits of 
sliding scales. On the basis of this collection of scales, and of his own study of arbitration proceedings and of personal inquiry in the North, is prepared the well-known work of $\mathrm{Mr}$. Price on Industrial Peace (1887). Mr. Price has made the subject of industrial conciliation peculiarly his own, and his comments from time to time on the changing situation, as they are to be read in the Economic Journal and elsewhere, will be found both informing and suggestive. A great deal of help may also be obtained from the History of Trade Unionism (1894) and the Industrial Democracy (1897) of Mr. and Mrs. Sidney Webb. And I take this opportunity of remarking that the value of the actual information as to the mechanism and immediate working of unionism which these writers furnish to us is quite independent of the validity of their ultimate conclusions. Of course all their narrative is arranged to converge in a certain direction; but with such good indices no one is compelled to read the boolis right through!

I have reserved for a place of honour at the end the series of publications connected with the Musce Social at Paris. It is a curious fact that practically the only attempts to come to close quarters with the problems of English industry, and especially those of the coal trade, in the way of concrete description of industrial environments and of organisation in relation to environment, have been made by a French institution. The Muséc Social, which began its work in 1896, owes its foundation to the generosity of the late Comte de Chambrun, who, after seeing it established, left it by will the whole of his considerable fortune, together with his house in one of the most quiet and aristocratic streets of the St. Germain quarter. Its function is the systematic collection of information concerning various practical directions of social reform, and the furnishing of advice to persons engaged in promoting it. The spirit of its management-which is in the hands of a committee composed of men of high social standing, including many leading officials in the civil service-may be described in the French term and with the French sense, as one of patronage, i.e. they are mainly interested in benevolent movements 'from above to below'-housing, provident funds and the like, or in efforts of a co-operative character. They are 
in touch with the numerous manufacturers all over the country, who are engaged in works of social amelioration under the auspices of the Catholic and Protestant churches. The Musée represents therefore an altogether different social milieu from either the socialist party or the syndicate propaganda (so closely associated with socialism in France). And yet it is in the Bulletins and other publications of this institution that we get perhaps the most interesting accounts of English unionism. The reason is that the investigators whom they have despatched to England have taken trouble, and have described honestly and entertainingly what they have seen; and finally, that English unionism, even the unionism of Mr. Pickard, seems to these continental observers an eminently conservative and sane phenomenon as compared with the unpractical utopias and violent class antagonisms which hinder the organisation of labour in their own country. The publications to which I am referring are the 'Circular' of March, 1896, translating Mr. Pickard's presidential address to the Miner's' Federation in that year, with historical introduction and explanatory notes; the 'Circular' of June, 1896, giving a full account of the proceedings at the International Congress of Miners in that year, with a biography of $\mathrm{Mr}$. Thomas Burt; that of August, 1897, giving the proceedings at the International Congress of the next year, with a biography of Mr. Ralph Young, corresponding secretary of the Northumbrian miners; and that of August, 1901, giving the proceedings of the International Congress of the same year. To these must be added the volume by M. Paul de Rousiers translated into English in 1896 under the title The Labour Question in Britain. This was indeed written (in 1893) before the Musée was established; but it is a product of the same group, and M. de Rousiers afterwards became the chief of the investigators representing the Musée. In collaboration with four younger men, he issued in 1897 the volume entitled Le Trade-Unionisme en Angleterre; and it is interesting to compare M. de Rousiers' own attitude, which is one of extreme individualism and distrust of associated action, with the sympathetic treatment which unionism receives from his younger fellow inquirers. M. de Rousiers' first volume is 
worth looking at, it may be remarked, as showing the best that can be done with the 'Le Play' method which has found so many admirers in France: the method, that is to say, of 'family monographs,' centring in a 'workman's budget.' His second volume, on the other hand, illustrates the method of institutional study-the study of the organisation of the group as a whole, with only occasional insertion of family bousekeeping particulars to enliven and make more vivid the picture. Both are most instructive works; and I would strongly recommend the second, that on Trade Lnionism in England, to anyone who is inclined to read a single volume which covers pretty well the whole field, industry by industry. Of course it has mistakes of detail ; but then it does manage to present a fairly distinct picture to one who knows nothing about the matter to begin with ; and that is a great merit. 
II. COAL MINING IN GREAT BRITAIN: RULES OF CONCILIATION BOARDS, \&C.

\section{The Federated Districts.}

Rules of Procedure for the conduct of the business of the Board of Conciliation, established between the Federated Coalowners and the Hiners' Federation of Great Brituin, to determine the Rate of Wages from January 1, 1901, to January 1, 1904, within the following limits, namely: That during such period the Rate of Wages shall not be below 30 per cent. above the Rate of Wages of 1888, nor more than 60 per cent. above the Rate of Wages of 1888.

1. Title.-The title of the board shall be "The Board of Conciliation for the Coal 'Trade of the Federated Districts.'

2. Object.- The board shall determine, from time to time, the rate of wages as from January 1, 1901.

3. Constitution of Board.-The board shall consist of an equal number of Coal Owners or Coal Owners' Representatives elected by the Federated Coal Owners, and Miners or Miners' Representatives elected by the Miners' Federation of Great Britain-fourteen of each, with a chairman from outside, who shall have a casting vote.

4. The present members of the board are and shall be:

Chairman: The Right Honourable Lord James of Hereford.

Coal Owners or Coal Owners' Representatives: Messrs. Alfred Hewlett, Walter L. Bourke, William Kellett, Henry Bramall, F. J. Jones, J. J. Addy, A. C. Briggs, A. J. Holiday, Fitzherbert Wright, J. A. Longden, Arthur G. Barnes, Henry Dennis, W. Heath, and Captain Harrison.

Miners or Miners' Representatives: Messrs. B. Pickard, M.P., S. Woode, William Parrott, Edward Cowey, Thomas 
Glover, W. E. Harvey, Thomas Chambers, Enoch Edwards, Benjamin Dean, Edward Hughes, J. G. Hancock, Andrew Sharp, William Abraham, M.P., and Robert Smellie.

Of whom Mr. Alfred Hewlett shall be President, and Mr. B. Pickard, M.P., Vice-President.

Whenever a vacancy has arisen, from any cause, on the board, except in the office of chairman, such vacancy shall be filled up within one month of its occurrence by the body which appointed the member whose seat has become vacant. Intimation of such appointment shall be at once sent to the secretaries. On the death, resignation, or removal of the first or any subsequent chairman, the board shall endeavour to elect another chairman, and should they fail, will ask the Speaker for the time being of the House of Commons to nominate one.

5. Place of Meeting.-The meetings of the board shall he held in London, or such other place as the board shall from time to time determine.

6. Short Referenee: 'The Parties.'-The constituents of the board, i.e. coalowners or coalowners' representatives, and miners or miners' representatives, are, for brevity, herein referred to as 'the parties.'

7. Secretaries.-The parties shall each respectively elect a secretary to represent them in the transaction of the business of the board, and each party shall give written notice thereof to the secretary of the other party, and both such secretaries shall remain in oftice until they shall resign or be withdrawn by the parties electing them. The secretaries shall attend all meetings of the board, and are entitled to take part in the discussion, but they shall have no power to move or second any resolution, or to vote on any question before the board.

8. Duties of Secretaries.-They shall conjointly convene all meetings of the board and take proper minutes of the board and the proceedings thereof, which shall be transcribed in duplicate books, and each book shall be signed by the chairman, president, or vice-president, or other person, as the case may be, who shall preside at the meeting at which such minutes are read and confirmed. One of such minute 
books shall be kept by each of the secretaries. The secretaries shall also conduct the correspondence for the respective parties and conjointly for the board.

9. Board Meetings.-The secretaries shall, on the written application of either of the parties made by the chairman and secretary of either party for an alteration in the rate of wages, or an alteration of these rules, or for any of the objects mentioned in Clause 4 , call a meeting of the board within twenty-one days, at such time and place as may be agreed upon by the secretaries. The application for the meeting shall state clearly the object of the meeting.

10. Duties of President, Vice-President, and Chairman.- The president, or, in his absence, the vice-president, shall preside at all the meetings at which the chairman is not present as herein provided. In the absence of both president and rice-president, a member of the board shall be elected by the majority to preside at that meeting. The president or vice-president, or other person presiding, shall vote as a representative, but shall not have any casting vote. When the chairman is present he shall preside and have a casting vote.

11. Business at Meetings of the Board.-All questions shall, in the first instance, be submitted to and considered by the board, it being the desire and intention of the parties to settle any difficulties or differences which may arise by friendly conference if possible. If the parties on the board camnot agree, then the meeting shall be adjourned for a period not exceeding twenty-one days, and the matter in dispute shall be further discussed by the constituents of the two parties, and the chairman shall be summoned by the secretaries to the adjourned meeting, when the matter shall be again discussed, and in default of an agreement by the parties on the board, the chairman shall give his casting vote on such matter at that meeting, which shall be final and binding.

12. Procedure.-All questions submitted to the board shall be stated in writing, and may be supported by such verbal, documentary, or other evidence and explanation as the partios may desire, subject to the approval of the board. 
13. Voting.-All votes shall be taken at meetings of the board by show of hands. When at any meeting of the board the parties entitled to vote are unequal in number, all shall have the right of fully entering into the discussion of any matters brought before them; but only an equal number of each shall vote. The withdrawal of the members of whichever body may be in excess to be by lot, unless otherwise arranged.

14. Expenses and Provision of Funds.-Each party shall pay and defray the expenses of its own representatives and secretary, but the costs and expenses of the chairman, stationery, books, printing, hire of rooms for meeting, shall be borne by the respective parties in equal shares.

Thos. Ratcliffe Elis, Joint Secretaries Thomas Ashton, of the Board.

\section{Northumberland.}

Rules of Procedure for the conduct of the business of the Board of Conciliation established between the Northumberland Coalowners' Association and the Northumberland Hiners' Associntion.

1. Title.-The title of the board shall be "The Board of Conciliation for the Coal Trade of the County of Northumberland.'

2. Object.- The board shall determine from time to time the county rate of wages.

3. Constitution of Board.-The board shall consist of an equal number of coalowners, or coalowners' representatives, elected by the Northumberland Coalowners' Association, and miners, or miners' representatives elected by the Northumberland Miners' Association, fifteen of each, with an independent chairman.

4. Appointment of Chairman.-The chairman to le elected annually by the members of the board. If they should not be able to agree on the appointment of a chairman, the chairman for the time being of the County Council of 
Northumberland shall be asked to nominate one after conferring jointly with the parties.

5. Vacancies. - Whenever a vacancy shall arise from any cause on the board, except in the office of chairman, such vacancy shall be filled up within one month of its occurrence by the association which appointed the member whose seat shall have become vacant. Intination of such appointment shall be at once sent to the other association.

6. Place of Meeting.-The meetings of the board shall be held in Newcastle-on-Tyne, or such other place as the board shall from time to time determine.

7. Short Reference: 'The Parties.' The members of the board, i.e. coalowners or coalowners' representatives, and miners or miner's' representatives, are for brevity herein referred to as 'the parties."

8. Secreturies. - The parties shall each respectively elect a secretary to represent them in the transaction of the business of the board, and each party shall give written notice thereof to the secretary of the other party, and both such secretaries shall remain in office until they shall resign or be withdram by the parties electing them. The secretaries shall attend all meetings of the board, and are entitled to take part in the discussion, but, unless they are members of the board, they shall have no power to move or second any resolution or to vote on any question before the board.

9. Duties of Secretaries.-They shall conjointly convene all meetings of the board, and talie proper minutes of the board and the proceedings thereof, which shall be transcribed in duplicate books, and each book shall be signed by the chairman or other person who shall preside at the meeting at which such minutes are read and confirmed. One of such minute books shall be liept by each of the secretaries. The secretaries shall also conduct the correspondence for the respective parties and conjointly for the board.

10. Board Meetings.-Ordinary meetings of the board shall be held as early as possible in the months of January, April, July, and October in each year. For the purpose of considering the election or re-election of the chairman, the secretaries shall, on the application of either party, convene 
a special meeting, to be held within twenty-one days of such application, to consider such election or re-election.

11. Chairman.-The chairman shall preside at all ordinary meetings at which he is present, and in default of agreement by the parties on any question before the board, he shall have power to decide such question as he may think fit, with or without modification by him of its terms as submitted to the board, and his decision shall be final and binding on all parties.

12. At special meetings of the board, or at ordinary meetings at which the chairman is not present, the members present shall appoint one of their number to preside, who shall have an initial vote as a member, but shall have no casting vote.

13. Voting.-All votes shall be taken at meetings of the board by show of hands. When at any meeting of the board the parties entitled to vote are unequal in number, all shall have the right of fully entering into the discussion of any matters brought before them; but only an equal number of each shall vote. The withdrawal of the members of whichever body may be in excess to be by lot, unless otherwise arranged.

14. Expenses.-Each party shall pay the expenses of its representatives and secretary, but the cost and expenses of the chairman, stationery, books, printing, hire of rooms for meeting, shall be borne by the respective parties in equal shares.

15. Alteration of Rules. - No alteration of these rules shall be made except at the July meeting in any year. Either party desiring an alteration of the rules shall, not less than one month before such meeting, give notice to the secretary of the other party of the alterations desired, and the secretaries shall, not less than fourteen days before such meeting, forward a copy of the proposed alterations to each member of the board.

16. Notice to Terminate.-The board shall continue until either party gives six months' notice of withdrawal from it, but neither party to withdraw before June 30,1901.

Newcastue : December 1899. 
2a. Northumberland-Wages and Prices, 1879-1902.

[Copy of a Card Issurid by the Union to its Mrabers.]

Northumberland Mincrs Mutual Contident Association.

Variations in prices and wages from June, 1879, to the present time.

The sliding scale was established in November, 1879, the basis price being $5 s .1 \cdot 28 \mathrm{~d}$. for a standard wage of $5 s .2 d$. In March, 1883, the basis price was reduced to $4 s .8 d$. for the same standard wage of $5 s .2 d$. This scale was terminated by the owners at the end of 1886 , and a reluction of $12 \frac{1}{2}$ per cent. enforced after a strike of seventeen weeks.

At the end of the strike in May, 1887, the scale was reestablished and the basis price raised to $5 s$. $5 d$., with an advance or reduction of $1 \frac{1}{4}$ per cent. for every $1 d$. rise or fall in price below 5s. 5d., which gave the above-mentioned $12 \frac{1}{2}$ per cent. reduction, and $1 \frac{1}{4}$ per cent. for every $2 d$. rise or fall in price above $5 s .5 d$. This scale was terminated by the workmen at the end of 1887 .

The Conciliation Board was established on the application of the workmen and the first meeting held July 24,1894 , under the chairmanship of J. Strachan, Barrister-at-Law. The Board was terminated on the notice of the workmen at the end of 1896. The Conciliation Board was re-established and the first meeting held January 1, 1900, under the chairmanship of Judge Greenwell.

R. Yound, Secretary.

Wages and Selling Prices.

\begin{tabular}{|c|c|c|c|c|c|c|}
\hline A-CERTAINEU SELLING $\mathrm{P}$ & RICE & & 1'HASEES & IN $\mathrm{W}$ & ars & \\
\hline \multirow{2}{*}{ Perio 1} & \multirow{2}{*}{$\begin{array}{c}\text { Average } \\
\text { Realised } \\
\text { Price }\end{array}$} & \multirow{2}{*}{$\begin{array}{l}\text { Date of Chatuge } \\
\text { taking effeet }\end{array}$} & \multirow{2}{*}{ Advance } & \multirow{2}{*}{ 离 } & \multicolumn{2}{|c|}{ Making Wages } \\
\hline & & & & & $\begin{array}{l}\text { Abore } \\
\text { Standard }\end{array}$ & $\begin{array}{c}\text { Below } \\
\text { Standard }\end{array}$ \\
\hline $\begin{array}{r}1879 \\
\left\{\begin{array}{l}\text { April, May, Jume. } \\
\text { Sept., Oct., Nov. }\end{array}\right. \\
\text { Dec., Jau., Fub. }\end{array}$ & $\left|\begin{array}{cc}\text { s. } & \text { d. } \\
4 & 7 \cdot 96 \\
4 & 5 \cdot 96 \\
4 & 5 \cdot 58\end{array}\right|$ & Jan., ${ }^{-} 1880$ & $\begin{array}{c}\text { Per } \\
\text { Oent. } \\
= \\
=\end{array}$ & $\begin{array}{c}\text { Per } \\
\text { Cent. } \\
-2 ! \\
-2\end{array}$ & $\begin{array}{c}\text { Per } \\
\text { Cent. } \\
= \\
=\end{array}$ & $\begin{array}{c}\text { Per } \\
\text { Cent. } \\
-2 \frac{1}{2}\end{array}$ \\
\hline
\end{tabular}




\section{Wages and Selling Prices-continued.}

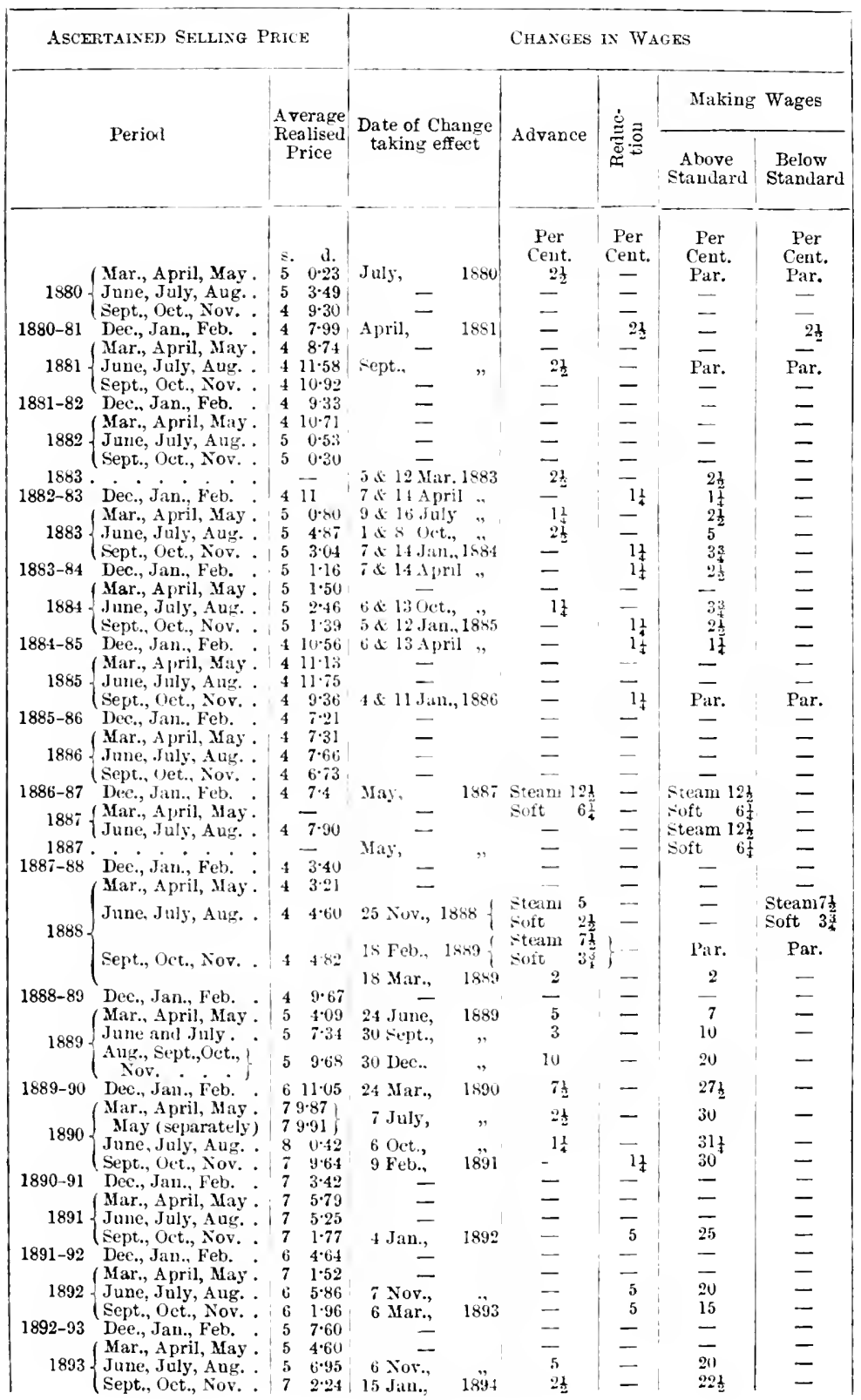


Wages and Selling Prices-continued.

Ascemfalnen seldisg Price

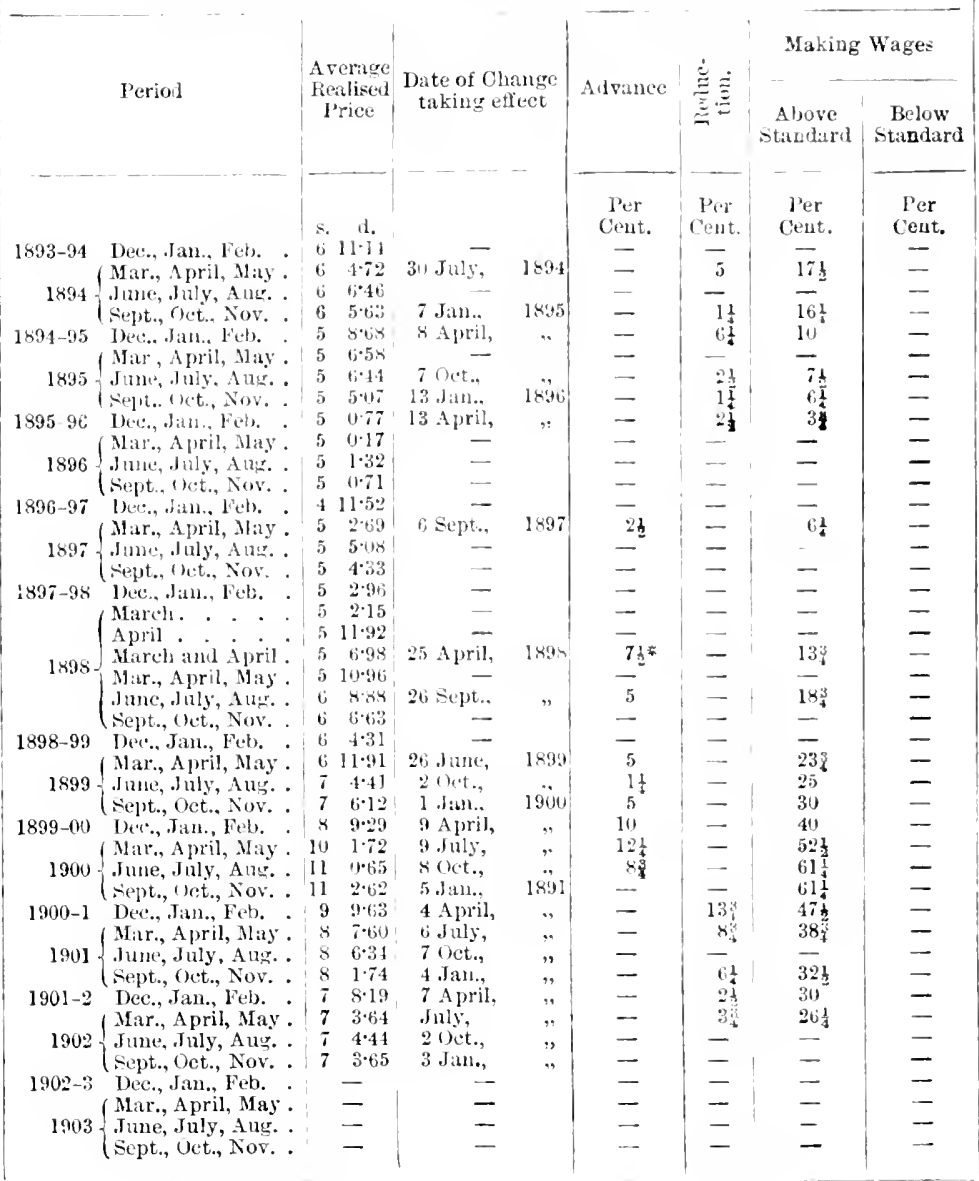

\section{Durham.}

Durham Coalowners' Association and Durham County Mining Federation. Conciliation Board.

The Durham Coalowners' Association and the Durham County Mining Federation hereby agree to form a 'Board of 
Conciliation for the Durham Coal Trade,' hereinafter called ' the Board.'

The following shall be the Objects, Constitution, and Rules of Procedure :-

\section{Objects.}

By conciliatory means to prevent disputes, and to put an end to any that may arise, and with this view to consider and decide upon all claims that either party may from time to time make for a change in county rates of wages or county practices, and upon any other questions, not falling within the jurisdiction of the Joint Committee, that it may be agreed between the parties to refer to the board.

Constitution and Rules of Procedure.

1. The board shall be constituted of the following number of representatives appointed by the following bodies, viz. by the

\begin{tabular}{|c|c|}
\hline Miner's' Association & \\
\hline Cokemen's Association & \\
\hline Mechanies' Association & \\
\hline Enginemen's Association & \\
\hline By the Coalowners' Asso & \\
\hline
\end{tabular}

2. The coalomers' representatives on the one hand, and the representatives unitedly of the four other associations on the other hand, are, for brevity, herein referred to as ' the parties.'

3. The board shall continue till either of the parties gives six months' notice of withdrawal from it, but neither of the parties to withdraw before the end of 1902 .

4. An umpire shall be forthwith agreed upon by the board, or, failing agreement, be appointed by the Board of Trade, after conferring unitedly with each of the parties represented by the board. Each umpire shall hold office until his successor is appointed. The board shall at its meeting in November, 1900, and in November of each 
succeeding year, and within one month of the death or resignation of any umpire, proceed to appoint a successor in the manner herein provided.

5. No decision shall be altered until it has been in operation for three calendar months.

6. All questions submitted to the board shall be stated in writing, and may be supported by such verbal, documentary, or other evidence as either party may desire to adduce and as the board may deem relevant.

7. All questions shall in the first instance be submitted to and considered by the board without the presence of the umpire, it being the desire and intention of the parties to settle, by friendly conference if possible, any difficulties or differences which may arise. If the board cannot agree, then the meeting shall be adjourned, and the umpire shall be summoned to the adjourned meeting, when the matter shall be again discussed, and in default of an agreement by the - board the umpire shall give his casting vote on such matter. 'The decision of the board or its umpire shall be final and binding on the parties.

8. The umpire may at his discretion require either party to afford him the means of obtaining, for the information of the board only, any facts that, in his judgment, are essential to the decision of any question at issue.

9. The parties shall each respectively elect a secretary to represent them in the transaction of the business of the board, and each party shall give written notice thereof to the secretary of the other party, and both such secretaries shall remain in office until they shall resign or be withdrawn by the party electing them. The secretaries shall attend all meetings of the board and be entitled to take part in the discussion, but they shall have no power to move or second any resolution or to vote on any question before the board, unless either secretary be also one of the representatives, in which case he shall in that capacity have all the rights and privileges of a representative.

10. The secretaries shall conjointly convene all meetings of the board, of which not less than seven days' notice shall be given, such notice specifying the business to be considered, 
and shall take proper minutes of the board and the proceedings thereof, which shall be transcribed in duplicate books, and each such book shall be signed by the umpire, chairman or vice-chairman, or other person, as the case may be, who shall have presided at the meeting to which such minutes relate. One of such minute books shall be kept by each of the secretaries. The secretaries shall also conduct the correspondence for the respective parties and conjointly for the board.

11. The secretaries shall, on the written application of either of the parties, made by the chairman and secretary of either party, call a special meeting of the board within 21 days, at such time as may be agreed upon by the secretaries. The application for the meeting shall state clearly the object of the meeting.

12. Each party shall pay the expenses of its own representatives and secretary, but the costs and expenses of the umpire, stationery, books, printing, hire of rooms for meetings, \&c., shall be borne by the respective parties in equal shares.

13. At the first meeting of the board in each year the board shall appoint a chairman and vice-chairman, one of whom shall be a representative of the Coalowners' Association, and the other of the Miners', Coliemen's, Mechanics', or Enginemen's Association.

14. The chairman, or in his absence the vice-chairman, shall preside at all meetings at which the umpire is not present as herein provided. In the absence of both chairman and vice-chairman a member of the board shall be elected by the majority to preside at that meeting. The chairman or vice-chairman, or other person presiding, shall vote as a representative, but shall not have any casting vote. When the umpire is present he shall preside and have a casting vote only.

15. Ordinary meetings of the board shall be held as early as possible in the months of February, May, August, and November in each year. The meetings of the board shall be held at Newcastle or such other place as the board shall from time to time determine. 
16. All votes shall be taken at meetings of the board by show of hands. When at any meeting of the board the representatives of the respective parties are unequal in number, all shall have the right of fully entering into the discussion of any matters bronght before them, but only an equal number of each shall vote, the withdrawal of the representatives of whichever party may be in excess to be by lot unless otherwise arranged.

For the Durham Coalowners' Association-

Reginald Gutunie, Secretary.

For the Durham County Mining l'ederation-

John Wilson,
John Johnson,
T. H. Cann,
W. House,
S. Galiraith,
W. Golightly,
G. MrGuinners,
T. Richlardson,
J. Leonard,

JoHN Wirson,

JoHN JoInson,

T. H. Cann,

W. House,

S. Gallibatith,

'T. Tircininson,

J. Leonaro,

October 17,1899 .
J. W. 'TAYuor,

W. Kratiris,

J. Fletciles,

W. H. Lamiton,

W. B. Charlton,

W. E. Nicilolson,

J. $\mathrm{O}_{\mathrm{GG}}$,

R. Hansom,

T. Dufry.
Mechanics.

Enginemen.

Cokemen.

3a. Durman: Joint Commetee Rules. (Reprinted June 1899.)

1. Formation of Committee.-The Joint Committee to be composed of six members of the Owners' Association and six members of the Workmen's Association, and a chairman to be chosen annually by the Owners' Association and the Federation Board.

2. Districts.-The collieries to be classed into three districts, with the following boundaries:- -

(a) The East District to comprise all those collieries which lie to the east of the Team Valley Railway.

(b) The North District to comprise all those collieries which lie to the west of the Team Valley Railway and north of the Lanchester Valley Railway. 
(c) The Auckland district to comprise all those collieries which lie to the west of the Team Valley Railway and south of the Lanchester Valley Railway.

The owner of any colliery situated on the boundary line of any district shall have the option of choosing the district in which such colliery shall be included.

3. Meetings. - The meetings of the Joint Committee to be held within the respective districts, or at such places as may be fixed upon as being most generally convenient for each district; and to be held at such times as may be approved by the chairman.

4. Order of Business.-At the meetings of the Joint Committee, the business of each district shall be considered in rotation, unless it shall be absolutely necessary for such meeting to act otherwise.

5. Representatives.-In any case brought before the Joint Committee, the owners may be represented by one or more of their agents, and the workmen by any of the workmen, or the check-weighman employed upon the colliery from which the case is sent.

6. Pouers of Committee.-The Joint Committee shall have full power to refer to arbitration, or otherwise settle all questions (except such as may be termed county questions, or which may affect the general trade) relating to wages, compensation for alteration in practices of working, and all questions or disputes of any other description which may arise from time to time at any particular colliery, between the owner of such colliery and his workmen, and which shall be referred to the consideration of the committee by either of the parties concerned, and the decision of the committee shall be final and binding upon all parties.

7. Alteration of Practices.-In the event of any alteration in the manner or system of working, in accordance with county arrangements, no stoppage of work shall occur pending the decision, by agreement or arbitration (to be afterwards confirmed by the Joint Committee), of any question as to readjustment of wage, or other question arising out of the altered mode of working. The decision shall date from the commencement of such alteration. 
8. Fixing Prices in new Seams, \&c.-The prices and wages to be paid to hewers employed in new seams, or at broken or other changed mode of working in any seam, for which prices are not already fixed, shall, on application, be settled by arbitration if they cannot be arranged by mutual agreement or by the Joint Committee.

9. Extension of Districts.-In cases of extension or recommencement of districts, the prices previously paid in such districts shall be paid in all extensions of the workings, except where boundaries are otherwise specifically defined.

10. Average Wages; 5 per cent. margin.-Before any change in the wages of hewers shall be entertained, it must be clearly shown that the average wage of the seam (or portion of a seam where cavilled separately) is at least 5 per cent. above or below the recognised average wages earned by hewers throughout the county of Durham.

11. Counter-claims.-All applications by one party for advances or reductions shall entitle the other side to open out the question of the prices paid to the same class of workmen throughout the whole of the seams, provided that, not less than seven clear days before the hearing by Joint Committee, a statement of any counter-claim intended to be made, together with the average wages of not less than three pays, shall be handed to the manager, or, as the case may be, to the workmen of the colliery, specifying the names of the districts where the advances or reductions are sought.

12. Objections to Hearing of Cases.-If any objection is to be raised to the hearing of any case, not less than seven clear days (or of any counter-claim four clear days) before the hearing by Joint Committee, a notice of such objection shall be handed to the manager, or, as the case may be, to the workmen of the colliery; or, if the cause of objection arises within such seven days or four days, then at any time previous to such meeting.

13. Standard Wage.-The average standard wage of hewers shall be $4 s .2 d$., modified up or down by any change brought about under any county agreement.

14. Revision of Prices.-The Joint Committee in considering claims for revision of hewing prices shall take the 
average wage for not less than three pays received by the workmen before the date of hearing (but excluding the two pays following the date of its being last heard, or from the date of an award; and the average wages of the first and last pays of the cavils).

15. Averages to be supplicd nine days before Hearing.No request for alteration of prices or of datal wages shall be entertained unless the average wages for not less than three pays or the datal wages paid to such workmen have been supplied, at least nine clear days before the hearing by Joint Committee.

16. Objections to Cases. - No demand from the workmen shall be entertained where early riding is a general practice ; or where it is shown that the workmen are restricting their work; or where it is proved that the men have generally limited their hours in riolation of the agreement of December 24, 1890 .

17. County Average.- No change shall be made in the prices and wages paid to any class of workmen for altered practices or conditions of working, unless it be clearly shown that thein average daily wage is reduced or increased thereby below or above the average daily wage of their class throughout the comty of Durham.

18. Pits laid idle.- If a pit is laid idle by the owners or workmen on account of any dispute between them, no claim by the offending party shall be considered until after work has been resumed.

19. Previous Dicirions.-No request shall be considered if the party making the application is proved not to be carrying out any previous decision of the Joint Committee, or award.

20. Backi Moncy.-In the event of any payment of back money being awarded, the chairman of the Joint Committee shall decide upon the period for which such payment shall be made.

21. Brokien Prices.-On the application of either party the broken area and distance from goaf within which broken prices shall be paid, shall, if not already fixed by agreement or custom, be fixed by the Joint Committee or by arbitration. 
22. Date of Alterations.- - Lnless otherwise arranged, all advances and reductions shall commence from the beginning of the next pay after the date of the decision or of the award.

23. Rehearing - Any case can be reconsidered after the lapse of twelve weeks from the date of its being last heard, or from the date of an award.

24. Order of Cases: Fourteen Days' Notice: Urgent Cases.-When both owners and workmen have cases for consideration the cases of each shall be considered alternately, and a circular, specifying the cases to be heard by the Joint C'rommittee at any meting, shall be sent to each member of the committee at least fourteen days before such meeting; and it shall not be competent for the committee to discuss any other matter than shall be specified in such circular, unless the parties concerned agree to any very urgent case being heard, and brth sides of the committee concur.

25. Appointment of Arbitiators.-In any case referred to arbitration each party shall appoint a disinterested arbitrator within twenty-one days of the date of the reference; and if within the said twenty-one days either of the parties fail to appoint an arbitrator, the arbitrator appointed shall ask the chairman of the Joint Committee to authorise him to hear and determine the matter referred, and malie an award, which shall be binding on loth parties.

26. Appointment of Umpire.-If, in any case referred to arbitration, the arbitrators fail to agree as to the appointment of an umpire, the chairman of the Joint Committee shall malie the selection of an umpire.

27. Voting.-All questions at any meeting of the Joint Committee shall, in the event of dissent, be determined by a majority in number of members to be ascertained by a show of hands, and the declaration of the chairman as to the result of any such show of lands shall be final. In case of an equality of votes between the owners' and the men's representatives, the chairman shall give his decision on the question at issue.

Decenber 6, 1892. 
Additional Joint Committee Rules (extracted from the Minute Books).

1. Average Wages. - It was agreed that Rule 10 applied to counter-claims. (March 11, 1898, East District.)

2. Kirvers. - It was ruled that men kirving are hewers, as named in Rule 10. (August 1, 1893, East District.)

3. Kirvers and Hewers when cavilled separately.-It was understood as regards Rule 10 that the average wages of kirvers and hewers when cavilled separately shall be taken separately. (September 25, 1893, East District.)

4. Tub-loaders.-Decided that tub-loaders are hewers, and included in Rule 10. (April 30, 1894, East District.)

5. Objections to Hearing of Cases.-Any objection by either party to the hearing of a case where any class of workmen are affected, referring to another class of workmen, shall not be valid. (June 25, 1894, East District.)

6. Revision of Hewing Prices.-It was agreed that Rule 14 was governed by Rule 10 -that is, there can be no revision of hewing prices at Joint Committee unless it be clearly shown that the average wage of the seam (or portion of a seam where cavilled separately) is at least 5 per cent. above or below the recognised average wages earned by hewers throughont the county of Durham. (January 27, 1893, Auckland District.)

7. Average Wages: Seams.-It was agreed that the seam's averages shall be separately supplied in each case. (March 13, 1896, North District.)

8. Districts.-Applications for advances or reductions of prices in seams shall be heard, although the averages of the separate districts have not been previously supplied. (December 10, 1897, North District.)

9. Exchanged. - Average and datal wages shall be exchanged between owners' and workmen's secretaries of Joint Committee. (July 29, 1898, East District.)

10. Shall be paid.-All average and datal wages for any pay shall be paid before being exchanged. (August 12, 1898, Auckland District.) 
11. Shall be dated.-All pays shall be dated, when average wages are supplied. (April 24, 1899, North District.)

12. Agreements. - It was agreed that settlements of local cases between the [Owners' and Worlimen's] Associations should be reported to the Joint Committee for convenience of reference. (May 3, 1897, Fast District.)

13. Date of Alterations.-It was agreed that, unless otherwise arranged, all awards and agreement operated from the first pay commencing after the date thereof. (March 7, 1892, North District.)

14. Reports.-All reports should be submitted to the next meeting of the Joint Committee for the same district after the date of reference. (July 11, 1890, North District.)

15. In future, when referees cannot agree upon a joint report, they shall send in separate reports, showing clearly where they are unable to agree. (July 8, 1895, Auckland District.)

June 30, 1899.

3B. Durhax.

Wages, 1897-1902.

\begin{tabular}{|c|c|c|c|c|c|c|c|}
\hline \multicolumn{4}{|c|}{ Per cent. } & \multicolumn{4}{|c|}{ Per cent. } \\
\hline 1897, & & $2 \frac{1}{2}$ & rance. & 1900 & Aug., & $8 \frac{3}{4}$ & vance. \\
\hline 1898, & & $2 \frac{1}{2}$ & , & & Nov., & 10 & \\
\hline , & & $2 \frac{1}{2}$ & " & 1901, & Feb., & $1 \frac{1}{4}$ & duction. \\
\hline , & & $2 \frac{1}{2}$ & " & " & May, & $11 \frac{1}{4}$ & , \\
\hline 1899, & & $1 \frac{1}{4}$ & $"$ & , & Aug., & $7 \frac{1}{2}$ & ", \\
\hline , & & $1 \frac{1}{4}$ & " & י & Nov., & 5 & " \\
\hline , & July, & $2 \frac{1}{2}$ & ", & 1902, & Feb., & $1 \frac{1}{4}$ & ," \\
\hline , & Sept., & $3 \frac{3}{4}$ & " & , & May, & $2 \frac{1}{2}$ & ", \\
\hline 1900 , & $\begin{array}{l}\text { Feb., } \\
\text { May, }\end{array}$ & $\begin{array}{l}5 \\
7 \frac{1}{9}\end{array}$ & ", & , & $\begin{array}{l}\text { Aug., } \\
\text { Nov.. }\end{array}$ & $\begin{array}{r}2 \frac{1}{2} \\
\text { No } c\end{array}$ & nge. \\
\hline
\end{tabular}




\section{Scotiland.}

Rules of Procedure for the Board of Conciliation, established between the Coalowners of Scotland and the Scottish Miners' Federation, on January 5, 1900.

1. Title.-The title of the board shall be 'The Board of Conciliation for the Regulation of Wages in the Coal Trade of Scotland.'

2. Object.-The board shall have for its object the regulation of miners' wages from February 1, 1900. From that date to August 1, 1900, the rate of wages shall not be reduced below a point of $31 \frac{1}{*}$ per cent. over the 1888 basis, nor be advanced above a point 75 per cent. over the 1888 basis.

3. Constitution of Board.- The board shall consist of twelve coalorners or coalowners' representatives elected by the coalowners, and twelve miners or miners' representatives elected by the miners.

4. Chairman and Vice-Chairman.-The chairman and vice-chairman shall be elected by the representatives to the board at the first meeting, the one being a coalowner, and the other a miners' representative.

5. Members of Board.-The first members of the board are and shall be:-Coalowners or Coalowner's representatives: Messr's. Andrew K. M'Cosh, John Wilson, M.P., Charles Thomson, John Addie, George A. Mitchell, James Nimmo, James Wood, James A. Hood, R. W. Wallace, Charles Carlow, James B. Thorneveroft, and James A. Clarke. Miners or Niners' representatives: Messrs. Robert Smillie, David Gilmour, John Robertson, James Murdoch, John Wilson, John M'Gough, Joln Guthrie, James Cook, Peter Muir, John Weir, James Innes, and Robert Brown. Of whom Mr. Andrew K. M'Cosh shall be chairman, and $\mathrm{M} i$. Robert Smillie vicechairman.

Vacancies. - Whenever a vacancy has arisen, from any cause, on the board, such vacancy shall be filled up within one month of its occurrence by the body which appointed the member whose seat has become vacant. Intimation of such appointment shall be at once sent to the secretaries. 
6. Place of Mecting.-The meetings of the board shall be held in Glasgow, or such other place as the board shall from time to time determine.

7. Short Reference: 'The Parties.'- The constituents of the board, i.e. coalowners or coalowner's' representatives, and miners or miners' representatives, are, for brevity, herein referred to as ' the parties.'

8. Secretaries.-The parties shall each elect a secretary to represent them in the transaction of the business of the board, and each party shall give written notice thereof to the secretary of the other party, and such secretaries shall remain in office until they shall resign or be withdrawn by the parties electing them. The secretaries shall attend all meetings of the board, and are entitled to take part in the discussion, but they shall have no power to move or second any resolution, or to vote on any question before the board, unless they are duly elected members of the board.

9. Duties of Secretaries.-The secretaries shall conjointly convene all meetings of the board and take minutes of the proceedings, which shall be entered in duplicate books, and each of these books shall be signed by the chairman, vicechairman, or other person, as the case may be, who shall preside at the meeting at which such minutes are read and confirmed. One of such minute books shall be kept by each of the secretaries.

10. Board Meetings.-The secretaries, on the written application of the chairman and secretary of either party for an alteration in the rate of wages, or an alteration of these rules, shall call a meeting of the board within fourteen days, at such time and place as may be agreed upon. The application for the meeting shall state clearly the object of the meeting.

11. Duties of Chairman and Vice-Chairman.-The chairman, or, in his absence, the vice-chairman, shall preside at all the meetings of the board. In the absence of both chairman and rice-chairman, a member of the board shall be elected by the majority to preside at that meeting. The chairman or vice-chairman, or other person presiding, shall vote as a representative, but shall not have any casting vote. 
12. Business at Meetings of the Board.-All questions as to general advances or general reductions in the rate of wages shall, in the first instance, be submitted to and considered by the board, it being the desire and intention of the parties to settle any such general advances or general reductions by friendly conference if possible. If the parties cannot agree, then the meeting shall be adjourned for a period not exceeding fourteen days, to allow the matter to be discussed by the constituents of the two parties. In the event of a disagreement at the second meeting a neutral chairman may be called in to settle the matter, but only if both parties agree to that course. If it is agreed to call in a neutral chairman, he shall be nominated at this second meeting, or an adjournment thereof, and a third meeting of parties shall be held not later than fourteen days thereafter. The decision of the neutral chairman shall be final and binding on both parties.

13. Procedure.-All questions submitted to the board under Rule 12 shall be stated in writing, and may be supported by such verbal, documentary, or other evidence and explanation as either party may submit, subject to the approval of the board.

14. Voting.-AIl votes shall be taken at meetings of the board by show of hands. When at any meeting of the board the parties entitled to vote are unequal in number, all shall have the right to take part in the discussion, but only an equal number of representatives of each party shall vote. The withdrawal of the members of either party which may be in excess will be by lot, unless otherwise arranged.

15. Expenses and Provision of Funds.-Each party shall pay and defray the expenses of its own representatives and secretary, but the costs and expenses for stationery, books, printing, hire of rooms for meetings shall be borne by the respective parties in equal shares.

Robert Baird,

Robert Brown,

Joint Secretaries of the Board.

January 5, 1900. 


\section{Conciliation Board.}

The committee recommend that the board should be continued under its present rules, and should agree as follows, viz. :-

1. That the present minimum and maximum in miners' wages, being $37 \frac{1}{2}$ per cent. and 100 per cent. over 1888 basis rates respectively, shall remain linding on both parties on the board: provided always that this obligation shall be terminable by either party on giving three months notice.

2. That the net average realised value of coal at the pitbank for the time being, taken in conjunction with the state of trade and the prospects thereof, is to be considered in fixing miners' wages between the minimum and maximum for the time being; and that in current ordinary circumstances a rise or fall of $6 \frac{1}{4} \mathrm{per}^{\circ}$ cent. in wages on 1888 hasis for each $4 \frac{1}{3} d$. per ton of rise or fall in the value of coal is reasonable.

3. That the present wage shall meanwhile be taken as rorresponding to a value of one penny per ton above the net average realised value of coal at the pit-lank in Scotland for the three months of December, Jannary, and February last, and for any average value $2 \frac{1}{4} d$. per ton over the same, and $2 \frac{1}{4} d$. per ton under the same.

4. The employers shall, by the machinery presently arranged with the Lanarkshire, the Fifeshire, and the Ayrshire Coalmasters' Associations, collect, and have tabulated by their accountants, the tomage of the total miners' ontput of coal from the associated collieries, for the above three months of December, January, and February, and the total net money received for the same at the pit-bank; and the net average receipts per ton, as shown by these figures, shall be accepted as the net average realised value of coal at the pit-bank in Scotland, referred to in Article 3 hereof-provided always that the miners' representatives shall be at liberty, at their own expense, to appoint accountants (to be approved of by the Conciliation Board, and pledged to secrecy) to verify the foresaid figures from the employers' books, or from any of them. 
5. When the employers, in any subsequent discussion, quote net average realised values for coal, the figures so quoted shall be accepted by the miners' representatives as correct-provided always that the miners' representatives shall be at liberty to verify the same from the employers' books, by their own accountants (as provided for in Article 4 hereof), who shall report within one week from the date of the meeting at which the quotations are made.

6 . While employers and workmen are confirmed in their freedom of employment and their rights at law, both parties will endeavour to insure regular working at the collieries; and the Miners' Federation will not be parties to throwing idle any colliery without adequate warning.

GLASGOW : May 1902.

With the view to making more clear the intention of parties under clauses 2 and 3 of the wages agreement entered into on May 26, 1902, it is agreed as follows, viz.:-

1. The nett average realised value of coal for the three months of December, January, and February last having been ascertained under Article 4 of agreement to be $7 \mathrm{s.} 0 \cdot 45 \mathrm{~d}$. per ton, or including the $1 d$. per ton agreed upon, $7 \mathrm{~s} . \mathbf{1} 45 \mathrm{~d}$. per ton, Article 3 provides that a wage 50 per cent. over 1888 basis shall meanwhile be taken as corresponding to any value of coal $2 \frac{1}{4} d$. per ton under and $2 \frac{1}{4} d$. per ton over that rate, viz. any value between $6 s .11 \cdot 20 d$. per ton and $7 s .3 \cdot 70 d$. per ton.

2. Thereafter wages may rise $6 \frac{1}{4} d$. per cent. whenever the average value of coal rises above $7 s .3 \cdot 70 d$. per ton to any extent within $4 \frac{1}{2} d$. per ton, and may fall by $6 \frac{1}{4}$ per cent. whenever the average value of coal falls below 6. s. 11:20d. per ton to any extent within $1 \frac{1}{2} d$. per ton. When values rise more than $4 \frac{1}{2} d$. per ton above $7 s .3 \cdot 70 d$. per ton, or fall more than $4 \frac{1}{2} d$. per ton below $6 s .11 \cdot 20 d$. per ton, another step is entered upon and a further advance or fall in wages to the extent of $6 \frac{1}{4}$ per cent. may take place; and so on by stages of $6 \frac{1}{4}$ per cent. on wages for $4 \frac{1}{2} d$. per ton on values of coal until the present maximum and minimum rates are reached, pro- 
vided always that the state and prospects of trade are such as to make said advances or reductions expedient.

Ascending.

\begin{tabular}{|c|c|c|c|c|c|c|c|}
\hline \multirow{2}{*}{ tween } & \multirow{2}{*}{ Y'er ton. } & \multicolumn{2}{|r|}{ Per ton. } & \multicolumn{4}{|c|}{ Over 1888.} \\
\hline & & & $a_{0}^{i} \cdot$ & Per cent & & & $\begin{array}{l}\text { Per cent. } \\
50\end{array}$ \\
\hline & -3.70 & ? & $8 \cdots 0$ & $6 i$ & dvance & & 561 \\
\hline " & 78.20 & 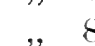 & 0.70 & $6 \frac{1}{1}$ & 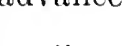 & & $62 \frac{1}{6}$. \\
\hline , & $8 \quad 0.70$ &, 8 & $5 \cdot 20$ & $6 \frac{1}{1}$ & ," & . & $68_{4}^{3}$. \\
\hline , & $8 \quad 5 \cdot 20$ &, & $9 \cdot 70$ & $6 !$ & ," & . & 75. \\
\hline ", & $8 \quad 9 \cdot 70$ &,$\quad !$ & $2 \cdot 20$ & $6_{4}^{1}$ & , & . & $81_{4}^{\frac{1}{4}}$. \\
\hline , & $\begin{array}{ll}9 & 2 \cdot 20\end{array}$ &,$\quad$ ! & 6.70 & $6 \frac{1}{4}$ & ,, & . & $87 \frac{1}{2}$ \\
\hline " & 960.70 & , & $11 \cdot 20$. & $6 i$ & ," & ${ }^{\circ}$ & $93 \frac{3}{4}$. \\
\hline " & $911 \cdot 20$ &,, 10 & $3 \cdot 70$ & $6 \frac{1}{4}$ & 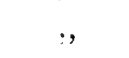 & & $.100 .^{I}$ \\
\hline \multicolumn{8}{|c|}{ Desecnding. } \\
\hline " & $7 \quad 3.70$ & $\Rightarrow$ & ; $11 \cdot 20$. & No & change & (basis) & ) 50. \\
\hline & (i) $11 \cdot 20$ & , & $; \quad 6 \cdot 70$. & $6 \frac{1}{4}$ & reductio & & . $43 \frac{3}{4}$. \\
\hline ", & i) $\quad 16.70$ & , & $2 \quad 2 \cdot 20$. & $6 \frac{1}{4}$ & , & & $37 \frac{1}{2} \cdot{ }^{2}$ \\
\hline
\end{tabular}

Decembir 115, 1:0:2.

\section{South Wales.}

[The Sliting Sicales of 1875,1880 , and 1882, will be found in Munro, Scales in the Coal Industry, 35-42. Another scalc was drawn up in 1890, and still another in 1892, which is given in the Board of Trade Report on Standard Piece Rates and Sliting Scales (1900), 10-15. After the unsuecessful strike against the sliding scale in 1898, in the course of which the miners of Sonth Wales received certain assist. ance from the Federation of Great Britain, the Sonth Wales Federation became. as it were, a probationary member of the Federation of Great Britain. It was the arowed policy of the Federation of Great Britain to so linit all wage agreements that the way should be clear at the end of 1903 for the construction of a single board covering the whole of Great Britain. The acceptance by the Welsh miners of an agreement for three years led accordingly to much discussion in the Federation of Great Britain. At a conference of the latter body, held on Friday, March 13, 1903, it was roted to concede freedom of action to the Welsh miners, by a resolution in the following terms:'That seeing the South Wales Conference of delegates have been unable to carry ont the Southport Conference resolution on the ques- 
tion of when agreements on the wages question shall commence and when they shall terminate, this conference cannot endorse the agree. ment entered into by the South Wales Miners' Conference, and therefore leaves the matter in the hands of the South Wales workers and their authorised committee; after which a further conference of the Miners' Federation of Great Britain shall be called together by the president and secretary to deal with the serious questions involved therein.'

\section{Memorandum of Agreement}

made this 31st day of March, 1903, between the undersigned -Williari Jenkins, Edwafi Jones, Fred. L. Davis, Charles H. Eden, M. Wolstenholie, Joseph Shaw, Henry Davies, J. Boyd Harvey, H. E. Gray, Thos. H. Deakin, W. S. B. McLaren, Willian Eraxi, William Sinth, H. W. Martin, Hugh Whtts, Thomas Grifriths, Fred. Cleeves, W. W. Hood, Hugit Bramweli, Thomas Wilson, W. D. Wight, and H. T'. WaLes, duly authorised to act on behalf of the owners of collieries in Monmouthshire and South Wales, whose names or titles are set forth in the schedule hereto (hereinafter called the owners), of the one part, and the undersigned-W. Amraitun, W. Brace, Alfred Onions, David Bernon, Evan Thoma, Dhid Watts Morgan, John Thomas, Enoch Molrell, 'Tiomis Erass, Chirles B. Stanton, Thomas Thouras, Joms Daries, Ben Davies, John Willinis, Thomas George, Thumls James, Jlmes Winstone, Vernon

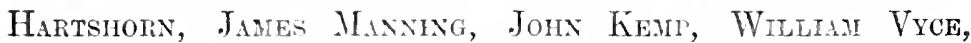
William E. Morg.1N, and Johix D. Morigis, duly authorised to act on behalf of the workmen (excepting enginemen, stokers, and outside fitters) now employed at the collieries of the said owners, of the other part, whereby it is mutually agreed as follows

1. That a Board of Conciliation shall be established to determine the general rate of wages to be paid to the workmen and to deal with disputes at the various collieries of the owners subject to the conditions hereinafter mentioned.

2. The title of the board shall be "The Board of Conciliation for the Coal Trade of Monmouthshire and South Wales,' hereinafter called 'the board.'

3. The board shall consist of twenty-four duly authorised owners' representatives and twenty-four duly authorised 
representatives of the workmen employed at the collieries of the owners, and when dealing with questions relating to general advances or general reductions in the rate of wages also of a chairman from outside, who shall not be financially interested in any coal mine in the United Kingdom, and who shall have a casting vote only.

4. The first members of the Board shall be the Ciminuin from outside as aforesaid, and who is hereinafter called the Chairman.'

\section{Owners' Representatives:-}

Willitati JENhINA

Edward Jones

Fren. L. Davis

Churles H. Eumex

M. Wolstenholme

Josepil Silaw

Henry Daves

J. Boyd Hanvey

H. F. GRAV

T. H. DEAKIN

W. S. B. McLaren

Williail EvaNs
Wilidian Sirtsh

H. W. Manitin

Hugh Watts

'T'Hovas Griffiths

Pred. Cleeves

IV. W. Hoos,

T. Forster Brown

Thomas Tilson

Clifford J. Cory

H. 'I'. Waces.

Fomeno Mirles Hann

W. J. Heppeti

Workmen's Representatives:-

Willian Amramadi

W. Brice

Alfred Onions

David Beynon

Evan Thomas

David Watts Morgan

John THomas

Enoch Morrell

Thomas Evans

Charles B. Stanton

Thonas Thomas

John Davies
Ben Davies

John Williams

Thomas Geopge

Thomas James

James Winstone

Vernon Harishorn

Jatres Minning

JoHN KEMP

William Vyee

Williay E. Morgan

JoHN D. MORGAN

${ }^{1}$ Sir Francis Hopwood, the Permanent Secretary of the Board of Trade, was unanimously invited to accept this position, but declined on the ground that it was inconsistent with his official position. 
of whom there shall be two presidents, one elected by the owners' representatives, and the other by the representatives of the workmen.

Whenever a vacancy on the board occurs from any cause (except in the office of chairman) such vacancy shall be filled within one month of its occurrence by the body which appointed the member whose seat has become vacant, but during such vacancy the board may transact the business of the board. Intimation of such appointment shall be at once sent to the secretaries. When and so often as the office of chairman becomes vacant the board shall endeavour to elect a chairman, and should they fail to agree, will ask the Lord Chief Justice of England for the time being, or in case of his refusal the Speaker of the House of Commons, to nominate one.

5. The parties to this agreement pledge their respective constituents to make every effort possible to avoid difficulties or disputes at the collieries, and in case of any unavoidable difference the owners or their officials, together with their workmen or their agent or agents, shall endeavour to settle all matters at the collieries, and only in case of failing to effect a. settlement shall a written appeal be made to the board by either or both of the parties concerned in the dispute to consider the same: and no notice to terminate contracts shall be given by either owners or their workmen before the particular question in dispute shall have been considered by the board and it shall have failed to arrive at an agreement. The board shall have power to refer such questions to a committee consisting of one or more owners' representatives and an equal number of workmen's representatives, all of whom shall be members of the board, to consider and if so directed with power to settle, and in all cases to report either a settlement or a failure to agree to the board, within three calendar months from the date of the reference to such committee; and should the board then fail to arrive at an agreement within one month, or any extended period that may be agreed upon by the board, either party may give notice to terminate contracts.

6. Rules of procedure for the conduct of the business of 
the board are set forth at the end hereof, and the same shall be deemed to be incorporated with and to form part of this agreement.

7. The mineral to be gotten is clean large coal only as hereinafter described.

The cutting prices to be paid to the collier shall be the several standard prices prevailing and paid at the collieries of the owners respectively.

Such standard cutting price shall be paid upon the weight of the large coal, to be ascertained in manner hereinafter appearing, and includes all services in respect of the small coal necessarily produced in filling the large coal, in conveying it from the working places to the screen at the surface, and in the process of screening; that price being equal to the value of all the services involved in getting such large coal and small coal, and being more than the value of the services rendered in respect of the large coal only.

The respective weights of such large coal and small coal for the purpose of paying the collier shall be ascertained as follows :-

After each tram of coal is brought to the weighing machine it shall be weighed, and the tare of the tram shall be deducted from the gross weight. The coal shall then be tipped over the screen in use at the colliery to separate the small coal passing through the screen from the large coal passing over it.

The small coal which shall pass through the screen shall be weighed, and that weight shall be deducted from the gross weight of the coal in the tram in order to ascertain the weights of such large screened coal and small coal respectively; and the cutting price paid to the collier upon the weight of the large screened coal as aforesaid shall during the continuance of this agreement be deemed to be the value of the services rendered in respect of both the large screened coal and small coal the weights of which respectively shall be ascertained as aforesaid.

8. It is distinctly understood that Clause 7 in this agreement is not intended to change the system of weighing and screening the coal as it at present exists, but the owners shall 
be at liberty to adopt such improved methods of screening as they may consider necessary, provided that any methods so adopted shall not in any way prejudicially affect the wages of the workmen.

9. Clause 7 shall not apply to or alter or in any way interfere with any agreements now existing or hereafter to be made for payment for through and through coal or where small coal is now separately paid for.

10. The board shall at the meetings held under Rule 6 of the said rules of procedure determine the general rate of wages to be paid for the three months commencing on the first day of the month following the dates of such meetings; but should neither party desire to vary the rate of wages, the then prevailing rate of wages shall continue until the same shall be varied in accordance with the said rules of procedure.

(a) All standard rates and prices shall be the standards known as the standards of December 1879 and 1877 respectively.

(b) The wages payable to the workmen shall, as from the date of this agreement and until the same shall be advanced or reduced by the board, be 48 . per cent. above the several rates actually paid at the respective collieries under the standard of December 1879.

(c) During the continuance of this agreement the rate of wages shall, subject to sub-section $d$ hereof, not be less than 30 per cent. above nor more than 60 per cent. above the December 1879 standard of wages paid at the respective collieries; and in considering any proposal for an alteration in the general rate of wages the said minimum of 30 per cent. shall for that purpose be considered as equiralent to such an average nett selling price per ton of large coal, not being less than $11 s .3 d$. nor more than $12 s .3 d$., as shall be forthwith determined by an independent person to be agreed upon by the parties, ${ }^{1}$ or, failing an agreement, to be nominated by the Lord Chief Justice of England, or, in case of his refusal, by the Speaker of the House of Commons. Such average nett selling price shall be takien as for large colliery screened coal,

- Sir David Dale, Bart., was unanimously invited to act in this capacity and consented. 
delivered f.o.b. at Cardiff, Barry, Newport, Swansea, and Llanelly.

(d) At collieries where the standard or basis upon which wages are now regulated is the rate of wages paid in the year 1877 the percentage payable thereat shall be 15 per cent. less than at the collieries where the 1879 standard prevails, provided that in cases where workmen have hitherto been paid nett rates of wages or fixed or other percentages, whether upon the 1877,1879 standards or any other existing standards, they shall continue to be paid such nett rates, fixed or other percentages only.

11. At the collieries under this agreement all wages due to the workmen shall be paid once in each fortnight, provided that at those collieries where wares are now paid weekly such practice shall continue in force.

12. A question having been raised by the owners as to the prices to be charged to workmen entitled to house coal for their own domestic purposes, it is agreed that the coal field shall be divided into not more than 10 sections, to be settled by the two chairmen and secretaries of the committee negotiating this agreement, or, failing them, by a third party to be nominated by them in advance, such division to be settled not later than April 30, 1903.

The prices to be paid for house coal in the various sections shall be first considered by the board, and in the event of their failing to agree by May 30, 1903, shall be fixed by the person to be appointed under Clause 10, subsection $c$ of this agreement, who shall give his decision not later than June 30, 1903.

In fixing the prices to be paid regard shall be had to the cost of production, the origin and conditions under which coal has been supplied to the workmen hitherto, also the quantity and quality of the same, and the period of supply in the different sections.

13. During the continuance of this agreement all notices to terminate individual contracts on the part of the owners as well as on the part of the workmen shall be given on the first day of any calendar month and shall terminate upon the last day of the same month, provided that if the first day of any 
calendar month fall on a Sunday, the notice shall be given on the previous Saturday.

14. Subject as aforesaid the owners and workmen at the respective collieries shall be bound to observe and fulfil and shall be subject to all customs, provisions, and conditions existing in December 1879 at the collieries respectively, and no variation shall be made therein by the owners or workmen, except by mutual arrangement at the collieries respectively or by a decision of the board, after a reference thereto in accordance with the provisions of Clause 5, of any proposal for a variation.

15. Nothing in the clauses of this agreement or in the rules of procedure is to preclude either party bringing any matters before the board or independent chairman which they consider as factors bearing upon the general wage question, but any evidence brought forward as to the selling price of coal shall be confined to the three calendar months immediately preceding the first day of the month in which the meeting is held.

16. This agreement shall continue in force until December 31,1905 , and shall then terminate, unless an agreement shall have been made before that date between the parties for an extended period. Upon the termination of this agreement all contracts of service between the owners respectively and their workmen respectively shall terminate.

17. A copy of this agreement shall be placed in a contractbook at each colliery, which shall be signed by or on behalf of the owners of such colliery and also by each workman employer thereat as one of the terms of the engagement between the owners and the said wortiman.

\section{Rules of Procedure.}

1. The constituents of the board-i.e. owner's' representatives and workmen's represeñialives-are for brevity herein referred to as 'the parties.'

2. The meetings of the board shall be held at Cardiff or such other place as the board may from time to time determine.

3. Each of the parties shall appoint a secretary, and shall 
give notice of such apprintment when made to the other party, and such seceretaries shall remain in office until they shall re-ign or be withdrawn be the parties approinting them. The seretaries or their respertive deputies for the time being shall attend all metings of the board and be entitled to take part in the discuseion, bnt they shall have no power to move or second any resolution or vote on any question before the broard.

4. The secretaries shall conjointly convene all ruetings of the broard and record the names of the persons present thereat, and at all metings held under Tiule $f$ of the rules of procedure full minutes of the procesedings thererof shall be taken, under the conjoint supervision of the sereretaries, by an official shorthand writer to be mutually argeed on by the parties, which minutes shall be transcribed into duplicate borks, and each such brok shall be signed by the presidents or other persons presiding at the meting at which such minutes are confirmerl. One of such rainute-broks shall be kept by each of the secretaries, such minutes to be for the private use of the brard and not for publication. The secretaries shall also conduct correspondence fro their respertive parties, and conjointly for the brast.

5). The brard shall met once at least in each month for the purpose of dealing with difficulties or disputes arising at the efveral collieries, and referred to in Clauses 5 and 14 of the foregoing agreement, and the same shall be dealt with by the board without reference to the chairman. The secretaries shall give to each member of the board five days' notice of the intention to hold any such meting, and of the business to be transacted thereat.

f. Should there be a desire by either party to vary the rate of wages, the board shall meet to consider the same on the 14th day of the months of February, May, August, and November in every year (except where the 14th day of any of the said months falls on a Sunday, when the meting shall be held on the following day), to determine the general rate of wages to be paid for the three months commencing on the 1st day of the month next following the date of such metings. Either party intending to proprose at such metings 
any alteration in the general rate of wages shall, ten days before the said 14th day of the months of February, May, August, and November, for holding such meetings, give to the secretary of the other party notice in writing of the proposition intended to be made, and of the grounds thereof, and the secretaries shall enter such intended proposition, and the grounds thereof, on the agenda to the notice convening the meeting. The secretaries shall send to each member of the board seven days' notice of each such meeting and of the business to be transacted thereat.

At all such last-mentioned meetings the questions to be dealt with thereat shall in the first instance be considered by the board, it being the desire and intention of the parties to settle any differences which may arise by friendly conference if possible. If the parties on the board cannot agree, then the meeting shall be adjourned for a period not exceeding seven days, to which adjourned meeting the chairman shall be summoned and shall attend and preside thereat, when the questions in difference shall be again discussed by the parties; and in the event of their failing to arrive at an agreement with regard thereto, the chairman either at such meeting or within seven days thereafter shall give his casting vote on such questions, and the parties shall be bound thereby.

7. Both presidents shall preside at all meetings (other than at meetings at which it shall be the duty of the chairman to preside in accordance with Clause 6 of these rules); but if either or both of them shall be absent, then a member or members of the board shall be elected by the respective parties to preside at such meetings according as such president who shall be absent shall represent the owners or workmen. The presidents or other persons presiding shall vote as representatives, but shall have no other votes.

8. All questions submitted to the board shall be stated in writing, and may be supported by such verbal, documentary, or other evidence and explanation as either party may submit, subject to the approval of the board.

9. Each party shall pay and defray the expenses of its 
own representatives, secretary, and accountant, but the costs and expenses of the chairman, official shorthand writer, and of the stationery, books, printing, and hire of rooms for meeting shall be borne by the respective parties in equal shares.

\section{W. Gascoyne Dalziei, Owners' Secretary. Thomas Richards, Workmen's Secretary.}

The Schedule referred to in the foregoing agreement.

Abercrave Collieries Co.

Albion Steam Coal Co.. Lta.

Ammanford Colliery Co., Ltd.

Bargoed Coal Co., Ittd.

Blaenavon Co., Ltd.

Blaenclydach Colliery Co., Ltd.

Blaina Colliery Co., Ltd.

Bwllfa \& Merthyr Dare Steam Collieries (1891), Ltd.

Cardiff Navigation Colliery Co.

Cartwright, T. G.

Corrwg Rhondda Colliery Co., Ltd.

Cory Bros. \& Co., Ltal.

Crawshay Bros. Cyfarthfa, Ltd.

Cwmaman Coal Co., Ltd.

Davis, D., \& Sons, Ltd.

Deep Navigation Collieries, Ltd.

Dinas Main Coal Co.

Ebbw Vale Steel, Iron \& Coal Co., Ittl.

Evans \& Bevan

Ffaldau Collieries Co., Ltd.

Foxhols Collieries Co., Lutd.

Gas Coal Collieries, Ltd.

Glamorgan Coal Co., Ltd.

Glyncorr'wg Colliery Co., Lttd.

Glynea Coal \& Briek Co., Ltd.

Glenavon Rhondda Collieries Co., Ltd.

Graigola Merthyr Co.. Ltd.

Great Mountain Collieries Co., Ltd.

Great Western Colliery Co., Ltd.

Guest, Keen is Nettlefolds, Ltd.

Gwauneae Gurwen Colliery Co., Ltd.
Gwendraeth Anthracite Collieries Co., Ltd.

Harry, David \& Bros.

Hedley's Collieries Co.

Hill's Plymouth Co.. Ltd.

IIoskins \& Islewellyn.

Insoles, Ltd.

International Coal Co., Ltd.

Laneaster, John \& Co., Ltd.

Lewis Merthyr Consolidated Col. lieries, Ltd.

Locket's Merthyr Collieries (1894), Ltd.

Main Colliery Co., Ltd.

Marquess of Bute.

Marquess of Bute, The Trustees of the.

Monmouthshire and $\mathrm{Cwm}$ Collieries Co.

New Cross Hands Collieries, Ltd.

Newport Abercarn Black Vein Steam Coal Co., Ltd.

Nixon's Narigation Co., Ltd.

North's Navigation Collieries (1889), Ltd.

Ocean Coal Co., Ltd.

Partridge Jones \& Co., Ltd.

Penrikyber Navigation Colliery Co., Ltd.

Pentremawr Colliery Co., Ltd.

Pont Henry Colliery Co., Ltd. Pontyberem Collieries Co., Ltd. Powell Duffryn Steam Coal Co., T.td.

Powells Tillery Steam Coal Co., Ltd. 
Pwllbach Colliery Co.

Rhymmey Iron Co., Ltd.

Rhos Colliery Co.

South Wales Anthracite Colliery Co., Ltd.

South Wales Primrose Coal Co., Ltd.

Thomas, Griftith.

Thomas, Samuel.

Tirpentwys Black Vein Steam Coal \& Coke Co., Ltd.
Tredegar Iron \& Coal Co., Ltd.

United National Collieries, Ltd. Universal Steam Coal Co., Ltd.

Vipond, John it Co, Ltd.

Vivian \& Sons.

Varteg Deep Black Vein Collieries, Ltd.

Williams, Representatives of the late E. D.

Williams, Thomas \& Sons.

Ynishir Steam Coal Co. 


\section{COAL MINING IN THE UNITED STATES : SOURCES OF INFORMATION.}

T'He statistics of output are given in the annual Reports on the Mineral Resources of the United States, issued by the U.S. Geological Survey, which performs in this respect the functions of the English Board of Trade. The figures down to 1900 are conveniently presented in the review of The Coal. Trade of the United States, which appeared in the Summary of Commerce and Finance for April 1900, issued by the Bureau of Statistics of the Treasury Department, and also separately. An elaborate account of the coal resources of the country, from the geological point of view only, is given in the Twenty-second Anmual Report of the U.S. Geological Survey, Part III. (1902).

Parallel to the volumes of the English Labour Commission of 1892-1894 are the nineteen volumes of the Reports of the Industrial Commission, issued between 1900 and 1902. Several of the volumes contain vast masses of information bearing upon mining conditions, especially volumes xii., xvii. and xix. Unfortunately, American Government reports are not published in the English fashion and offered to any would-be purchasers at a fixed price. They are distributed only in 'allotments' to senators and representatives; and the surplus, if any, is given away by the office to persons known to be interested. Accordingly, though those who do obtain them get them more cheaply than in England-for English Government offices have no special regard for mere professors-those who do not happen to get them at the time are in a worse plight than in England. I have to thank a number of American friends, and especially Professor Ripley of Harvard, and Professor Jenks of Cornell (both of whom acted as 'Expert Agents' for the Commission), for enabling me to make up my set. 
On the great strike of 1898 in the bituminous field, and on the subsequent settlement there, there are two very useful articles in the Quarterly Journal of Economics for 1898, by my former pupil Mr. George, himself once a miner and now a Professor of Economics in a vell-known college. For the Anthracite Coal Industry there is an elaborate monograph by Dr. Roberts (1901). The efforts towards capitalistic combination are narrated and explained in a substantial piece of investigation by a former graduate student of Harvard, $\mathrm{Mr}$. Virtue, in the Quarterly Journal of Economics for 1896, and on this is based the chapter in de Rousiers' Industries Monopolisées aux États Unis (1898). To Bulletin 13 of the Department of Labor (November 1897) $\mathrm{Mr}$. Virtue has also contributed a full account of the conditions of labour and the attempts at organisation among the anthracite miners up to 1897. In Bulletin 43, finally, will be found the report to the President by the Commissioner of Labour, and a most important series of letters and memoranda by the leading anthracite operators.

Parallel to the Reports of Proceedings before the English Conciliation Boards, are the Reports of the Interstate Convention of Coal Miners and Operators of Illinois, Indiana, Ohio, and Pennsylvania. Of these I have been enabled to make use of the Fourth and Fifth $(1901,1902)$. As the proceedings of the sub-Scale Committee, which as a rule finally determines the rate for the ensuing year, are not published, these reports are neither so confidential nor so valuable as their English parallels. For the miners' side of current coniroversies they may be supplemented by the annual Minutes of the Convention of the United Mine Workers. For recent opinion on the labour question in general in the United States, reference may be made to the work of $\mathrm{Mr}$. Graham Brooks, The Social Unrest, and to the Report of the Industrial Conference of the National Civic Federation, December 1902. The Report to the President by the Anthracite Coal Strike Commission has appeared too late to be used in these Lectures. Some comments upon it will be found in the Preface, and the Awards of the Commission are printed in Appendix VII. 


\section{COAL MINING IN THE UNITED STATES: JOINT AGREEMENTS, \&C.}

Interstate Agreenent between the United Mine Workers of America and the Cola Operators of Pennsyluania, Ohio, Indiana, and Illinois.

Covering and effective during the Scale Year from April 1, 1900, to April 1, 1901.

A specimen of the goneral arreenents for the whole 'competitive field,' which have been drawn up each year since 1898. It settles the wide limits within which the State and district agreenents can determine the conditions of labour.

It is hereby agreed :

Secrion I. (a) That an advance of fourteen (14) cents per ton of two thousand $(2,000)$ pounds for pick mined, screened coal shall take effect in Western Pennsylvania thin vein, the Hocking, the basing district of Ohio, and the block coal district of Indiana.

(b) That the Danville district, the basing point of Illinois, shall be continued on an absolute rum-of-mine basis, and that an advance of nine (9) cents per ton over present prices be paid in the district named.

(c) That the bituminous coal district of Indiana shall pay forty-nine (49) cents per ton for all mine-run coal loaded and shipped as such. All other coal mined in that district shall be passed over a regulation screen, and be paid for at the rate of eighty $(80)$ cents per ton of two thousand $(2,000)$ pounds for screened lump.

Section II. That the screen hereby adopted for the State of Ohio, Western Pennsylvania, and the bituminous district of Indiana shall be uniform in size, six (6) feet wide by twelve (12) feet long, built of flat or Akron-shaped bar of not less than five-eighths ( $\left.\begin{array}{c}5 \\ 5\end{array}\right)$ of an inch surface, with one and one-fourth (1) inches between bars, free from obstructions, and that 
such screen shall rest upon a sufficient number of bearings to hold the bars in proper position.

Section III. That the block coal district of Indiana may continue the use of the diamond bar screen, the screen to be seventy-two (72) feet superficial area, of uniform size, one and one-quarter $\left(1 \frac{1}{4}\right)$ inches between the bars, free from olstruction, and that such screens shall rest upon a sufficient number of bearings to hold the bar's in proper position.

Section IV. That the differential between the thick and thin vein pick mines of the Pittsburg district be referred to that district for settlement.

Section V. (a) That the price of machine mining in the bituminous district of Indiana shall be eighteen (18) cents per ton less than the pick mining rate for screened lump coal, when punching machines are used; and twenty-one and onehalf $\left(21 \frac{1}{2}\right)$ cents per ton less than pick mining rates when chain machines are used.

When coal is paid for on run-of-mine basis, the price shall be ten (10) cents. per ton less than the pick mining rate when punching machines are used, and twelve and one-half (12 $\left.\frac{1}{2}\right)$ cents per ton less than pick mining rates when chain machines are used.

(b) That the machine mining rate in the Danville district, the basing point of Illinois, on both punching and chain machines be thirty-nime (39) cents per ton.

Section VI. That the machine mining rate in the thin vein of the Pittsburg district, and the Hocking, the basing district of Ohio, for shooting, cutting, and loading, shall be advanced nine (9) cents per ton; and that the block coal district of Indiana shall be advanced eleven and one-half (11) cents per ton.

Section VII. That the mining rates in the central district of Pennsylvania be referred to that district for adjustment.

Section VIII. That the advance on inside day labour be twenty (20) per cent., based on the present Hocking Valley scale; with the exception of trappers, whose compensation shall be one dollar (\$1.00) per day.

Section IX. That all narrow, dead work, and room turning shall be paid a proportionate advance with the pick mining rate. 
Section X. That internal differences in any of the States or districts, both as to prices or conditions, shall be referred to the States or districts affected for adjustment.

Section XI. The above scale is based upon an eight (8) hour workday.

The foregoing scale, having been unanimously adopted by the interstate convention of miners and operators at Indianapolis, Indiana, on February 2, 1900, in witness hereof we hereto attach our signatures:-

In behalf of Operators.-F. L. Robbins, Wm. B. Rodgers, for Pennsylvania ; J. S. Morton, Walter J. Mullins, for Ohio; J. Smith Talley, A. M. Ogle, for bituminous district of Indiana; W. W. Risher, M. H. Johnson, for block coal district of Indiana; E. T. Bent, Chas. E. Hull, for Illinois.

In behalf of Miners.-P. Dolan, Wm. Dodds, for Pennsylvania; W. H. Haskins, T. L. Lewis, for Ohio ; William Wilson, Barney Navin, for block coal district of Indiana; W. D. Van Horn, J. H. Kennedy, for bituminous district of Indiana; John M. Hunter, W. D. Ryan, for Illinois.

In behalf of U.M.IV. of $A$.

John Mitchell, President.

IV. C. Pearce, Secretary.

Attest: F. S. Brooks, Secretary.

2. Illinois State Agreement for Scale Year ending Marcil 31, 1903.

Whereas a contract between the operators of the competitive coal fields of Pennsylvania, Ohio, Indiana, and Illinois and the United Mine Workers of America, has been entered into at the city of Indianapolis, Ind., February 8, 1902, by which the present scale of prices at the basic points, as fixed by the agreement made in Indianapolis, Ind., February 2, 1900 , is continued in force and effect for one year from April 1, 1902, to March 31, 1903, inclusive; and,

Whereas this contract fixes the pick-mining price of bituminous mine-run coal at Danville, at 49 cents per ton of 2,000 pounds: Therefore, be it 
Resolved, That the prices for pick-mined coal throughout the State for one year beginning April 1, 1902, shall be as follows:-

\section{First District.}

Streator, Cardiff, Clarke City, and associated mines, including $\$$

Toluca thick vein . . . . . . . . . . . . . . . . S

Third vein and associated mines, inclnding 24 inches of brushing . $\quad .76$

Wilmington and associated mines, including Cardiff long wall and

Bloomington thin vein, including brushing . . . . . . $\quad .81$

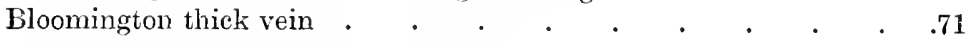

Pontiac, including 24 inches of brushing . $\quad . \quad$. $\quad . \quad$. $\quad$. $\quad .81$

Pontiac top vein . . . . . . . . . . . . . . . . . . .

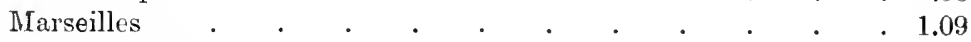

Tate at Marseilles to continue until september 1, 1902, at which time the conditions are to be investigated by President Russell and Commissioner Justi, and if conditions are changed as now contemplated an equitable adjustment shall be made.

Norris and Seneca (referred to a committee composed of Com. missioner Justi and two operators and President Riussell and two miners to fix mining prices, which shall become a part of this contract; the same to be considered before May 1, 1902).

Clarke City lower seam, brushing in coal

Second District.

Danville, Westville, Grape Creek, and associated mines in Vermilion County . . . . . . . . .

Thivd District.

Springfield and associated mines . . . . . . . . .497

Lincoln and Niantic . . . . . . . . . . . . $\quad .53$

Colfax . . . . . . . . . . . . . . .

Fouvth District.

Mines on Chicago and Alton south of Springfield, to and including

Carlinville; including Taylorville, Pana, Litchfield, Hillsboro,

Vitt (Paisley), Dirernon, and Pawnee . . . . . . $\quad .49$

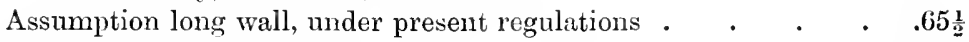

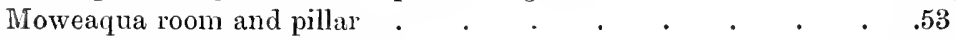

Mount Pulaski room and pillar . . . . . . . . . $\quad .66$

Decatur, present conditions . . . . . . . . . .

Fifth District.

Glen Carbon, Belleville, and associated mines, to and including

Pinckneyville, Willisville, and Nashville . . . . . . $\quad .49$

Coal 5 feet and under . . . . . . . . . . . . . .54 
Sixth District.

Du Quoin, Odin. Sandoval, Centralia, and associated mines . . . . 45

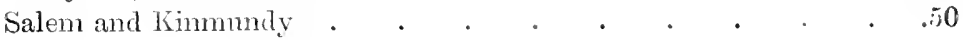

Seventh District.

Mount Vernon

Jackson County . • • • • • . • • • • .

(All coal 5 feet and under, 5 cents extra per ton; this not to apply to lower bench, nor rolls or horscbacks.)

Lower bench, Jachson County, for shipping mines, miners to carry 14 inches brushing . . . . . . . . . Saline County . . . . . . . . . . . .

Williamson Comty · * · · · · · $\cdot$.

Gallatin County (price to be determined by Thomas Jeremiah and Commissioner Justi and becone a part of this contract).

\section{Eighth Iistrict.}

Fulton and Peoria counties, thin or lower vein (third vein conditions) . . . . . . . . . .

Fulton and Peoria counties, No. 5 vein . . . . . . . . .56

Astoria, No. 5 vein (Fulton and Peoria comties' conditions) . . . .56

Pekin (price of 60 cents per ton continued under provisions similar to those in State agreement for year ending April 1, 1902, viz. : Price of 60 cents per ton, with Fulton and Peoria counties' conditions to be in force for 90 days, from April 1, 1902, during which time a record is to be liept to determine cost of removing dirt, se. Should this rate be found to work a hardship, it shall be readjusterl; if it transpires that it is equitable it shall continue during the life of this agreement. It is understood that the Pekin operators and delegates will determine by what method the readjustment shall be considered).

Fulton and Peoria counties, No. 6 vein (reforred to a committee composed of Commissioner Justi and two operators and President Russell and two miners to fix a mining price which shall become a part of this contract; the present rate of 59 cents per ton to continue in force pending adjustment by said committee. The same to be considered before May 1, 1902).

Gilchrist, Wanlock, Cable, Sherrard, and silvis mines, 60 cents per ton with last year's conditions. In case of deficient work, where miner and mine manager cannot agree as to compensation, the nime committee shall be called in; and, if they can not agree, the dispute shall be carried ny under the thirteenth clanse of the present scale.

Kewanee and Etherley . · · · · · $\cdot \cdot \cdot$

Pottstown, No. 1 seam, scale to be the same as Gilchrist and

Wanlock, except in the brushing of the top. that shall be settled by the subdistrict. 


\section{Ninth District.}

Mount Olive, Stamton, Gillespie, Clyde, Sorento, and Coffeen, and mines on the Vandalia line as far east as and including Smithboro, and on the B. \& O.S.W. as far east as Breese . . $\quad .49$ Coal 5 feet and under

1. The Indianapolis convention, having adopted the mining and underground day-labour scale in effect April 1, 1900, as the scale for the year beginning April 1, 1902, no changes or conditions shall be imposed in the Illinois scale for the coming year that increase the cost of production of coal in any district in the state, except as may be provided.

2. No scale of wages shall be made by the United Mine Workers for mine manager, mine manager's assistant, top foreman, company weighman, boss drivers, night boss, head machinist, head boilermaker, head carpenter, night watchman, hoisting engineers. It being understood that 'assistant' shall apply to such as are authorised to act in that capacity only. The authority to hire and discharge shall be rested in the mine manager, top foreman, and boss driver. It is further understood and agreed that the night watchman shall be exempt when employed in that capacity only.

3. Any operator paying the scale rate of mining and day labour under this agreement, shall at all times be at liberty to load any railroad car's whatever, regardless of their ownership, with coal, and sell and deliver such coal in any market and to any person, firm, or corporation that he may desire.

4. The scale of prices for mining per ton of 2,000 pounds run-of-mine coal herein provided for, is understood in every case to be for coal free from slate, bone, and other impurities, loaded in cars at the face, weighed before screening; and that the practice of pushing coal by the miners shall be prohibited.

5. (a) Whether the coal is shot after being undercut or sheared by pick or machine, or shot without undercutting or shearing, the miners must drill and blast the coal in accordance with the state mining law of Illinois, in order to protect the roof and timbers in the interest of general safety. If it can be shown that any miner persistently violates the letter or spirit of this clause, he shall be discharged. 
(b) The system of paying for coal before screening was intended to obviate the many contentions incident to the use of screens, and was not intended to encourage unworkmanlike methods of mining and blasting coal, or to decrease the proportion of screened lump; and the operators are hereby guaranteed the hearty support and co-operation of the United Mine Workers of America in disciplining any miner who from ignorance or carelessness or other cause fails to properly mine, shoot, and load his coal.

6. In case slate, bone, clay, sulphur, or other impurities are sent up with the coal by the miner, it shall be the duty of whomever the company shall designate as inspector to report the same, with the estimated weight thereof, and the miner or miners so offending shall have such weight deducted from the established weight of the car, and for the first offence in any given month shall be fined 50 cents; for the second offence in the same month he or they shall, at the option of the operator, be fined $\$ 2$ or suspended for two working days; and for the third or any subsequent offence in the same month, or in malicious or aggravated cases for the first or any subsequent offence, the operator may indefinitely suspend or discharge.

The company weighman shall post in a conspicuous place at the pit head the names of all miners dealt with hereunder.

The inspector designated by the operator shall be a member of the United Mine Workers of America, but in the discharge of the duties herein specified shall not be subject to the jurisdiction of the local union or president or pit committee, and against any miner or committeeman seeking in any way to embarrass the inspector in or because of the discharge of such duties, the provisions of the miners' State constitution shall be invoked, and in addition he shall, at the option of the operator, be suspended for two working days.

In case it shall be alleged by either the local representatives of the miners or by the operator that the inspector is not properly performing his duties hereunder, it shall be so reported to the miners' subdistrict president, who shall, within forty-eight hours after the receipt of notification, take 
it up with the superintendent of the company for adjudication; and, if it shall be found that the inspector is not faithfully performing such duties, he shall be discharged or transferred to other duties, as the operator may elect.

The proceeds of all fines hereunder shall be paid to the miners' subdistrict secretary-treasurer, and under no circumstances shall any such fine be remitted or refunded.

7. The miners of the state of Illinois are to be paid twice a month, the dates of pay to be determined locally, but in no event shall more than one-half month's pay be retained by the operator. When any number of men at any mine so demand, statements will be issued to all employees not less than twenty-four hours prior to pay day. No commissions will be charged for money advanced between pay days, but any advance between pay days shall be at the option of the operatol.

8. The price for powder per keg shall be $\$ 1.75$. The miners agree to purchase their powder from the operators, provided it is furnished of standard grade and quality; that to be determined by the operators and expert miners jointly, where there is a difference.

9. The price for blacksmithing for pick mining shall be six-tenths of a cent per ton for room and pillar work, and $12 \frac{1}{2}$ cents per pay per man, or 25 cents per month for long wall or pick and drill sharpening.

10. It is understood that there is no agreement as to the price of oil.

11. The inside day-wage scale authorised by the present agreements, i.e. the Columbus scale of 1898 , plus an advance of 20 per cent., shall be the scale under this agreement; but in no case shall less than $\$ 2.10$ be paid for drivers.

12. The above scale of mining prices is based upon an eight-hour workday, and it is definitely understood that this shall mean eight hours' work at the face, exclusive of noon time, six days a week, or forty-eight hours in the week, provided the operator desires the mine to work; and no local ruling shall in any way affect this agreement or impose conditions affecting the same.

Any class of day labour may be paid, at the option of the 
operator, for the number of hours and fractions thereof actually worked, at an hour rate based on one-eighth of the scale rate per day: Provided, hovever, That when the men go into the mine in the morning they shall be entitled to two hours' pay whether the mine hoists coal two hours or not, except in the event that they voluntarily leave their work during this time without the consent of the operator they shall forfeit such two hours' pay: Provider, further, That overtime by day labourers, when necessary to supply railroad chutes with coal by night or Sunday, where no regular men therefore are exclusively employed, or when necessary in order not to impede the operation of the mine the day following, and for work which can not be performed or completed by the regular shift during regular hours without impeding the operation of the mine, may be performed and paid for at the same rate per hour.

13. (a) The duties of the pit committee shall be confined to the adjustment of disputes between the pit boss and any of the members of the United Mine Workers of America working in and around the mine, for whom a scale is made, arising out of this agreement or any subdistrict agreement made in connection herewith, where the pit boss and said miner or mine labourers have failed to agree.

(b) In case of any local trouble arising at any shaft through such failure to agree between the pit boss and any miner or mine labourer, the pit committee and the miners' local president and the pit boss are empowered to adjust it; and in the case of their disagreement it shall be referred to the superintendent of the company and the president of the miners' local executive board, where such exists; and shall they fail to adjust it-and in all other cases-it shall be referred to the superintendent of the company and the miners' president of the subdistrict; and, should they fail to adjust it, it shall be referred in writing to the officials of the company concerned and the State ofticials of the United Mine Workers of America for adjustment; and in all such cases, the miners and mine labourers and parties involved must continue at work, pending an investigation and adjustment, until a final decision is reached in the manner above set forth. 
(c) If any day men refuse to continue at work because of a grievance which has or has not been taken up for adjustment in the manner provided herein, and such action shall seem likely to impede the operation of the mine, the pit committee shall immediately furnish a man or men to take such vacant place or places at the scale rate, in order that the mine may continue at work; and it shall be the duty of any member or members of the United Mine Workers, who may be called upon by the pit boss or pit committee, to immediately take the place or places assigned to him or them in pursuance hereof.

(d) The pit committee, in the discharge of its duties, shall under no circumstances go around the mine for any cause whatever, unless called upon by the pit boss or by a miner or company man who may have a grievance that he cannot settle with the boss; and, as its duties are confined to the adjustment of any such grievances, it is understood that its members shall not draw any compensation except while actively engaged in the discharge of said duties. Any pit committeeman who shall attempt to execute any local rule or proceeding in conflict with any provision of this contract, or any other made in pursuance hereof, shall be forthwith deposed as committeeman. The foregoing shall not be construed to prohibit the pit committee from looking after the matter of membership dues and initiations in any proper manner.

(e) Members of the pit committee employed as day men shall not leave their places of duty during working hours, except by permission of the operator, or in cases involving the stoppage of the mine.

$(f)$ The right to hire and discharge, the management of the mine, and the direction of the working force are vested exclusively in the operator, and the United Mine Workers of America shall not abridge this right. It is not the intention of this provision to encourage the discharge of employees, or the refusal of employment to applicants, because of personal prejudice or activity in matters affecting the United Mine Workers of America. If any employee shall be suspended or discharged by the company and it is claimed that an injustice 
has been done him, an investigation to be conducted by the parties and in the manner set forth in paragraphs $(a)$ and $(b)$ of this section shall be taken up promptly ; and, if it is proven that an injustice has been done, the operator shall reinstate said employee and pay him full compensation for the time he has been suspended and out of employment: Provided, If no decision shall be rendered within five days, the case shall be considered closed in so far as compensation is concerned.

14. The wages now being paid outside day labour at the various mines in this state shall constitute the wage scale for that class of labour during the life of this agreement: Provided, That no top man shall receive less than $\$ 1.80$ per day.

15. In the event of an instantaneous death by accident in the mine, the miners and underground employees shall have the privilege of discontinuing work for the remainder of that day ; but work, at the option of the operator, shall be resumed the day following, and continue thereafter. In case the operator elects to operate the mine on the day of the funeral of the deceased, as above, or where death has resulted from an accident in the mine, individual miners and underground employees may, at their option, absent themselves from work for the purpose of attending such funeral, but not otherwise. And in the event that the operator shall elect to operate the mine on the day of such funeral, then from the proceeds of such day's operation each member of the United Mine Workers of America employed at the mine at which the deceased member was employed shall contribute 50 cents and the operator $\$ 25$ for the benefit of the family of the deceased or his legal representatives, to be collected through the office of the company. Except in case of fatal accidents, as above, the mine shall in no case be thrown idle because of any death or funeral; but in the case of the death of any employee of the company or member of his family, any individual miner may, at his option, absent himself from work for the sake of attending such funeral, but not otherwise.

16. (a) The scale of prices herein provided shall include, in ordinary conditions, the work required to load coal and properly timber the worling places in the mine, and the operator shall be required to furnish the necessary props and 
timber in rooms or working face. And in long wall mines it shall include the proper mining of the coal and the brushing and care of the working places and roadway according to the present method and rules relating thereto, which shall continue unchanged.

(b) If any miner shall fail to properly timber, shoot, and care for his working place, and such failure has entailed falls of slate, rock, and the like, the miner whose fault has occasioned such damage shall repair the same without compensation; and if such miner fails to repair such damage he may be discharged.

Any dispute that may arise as to the responsibility under this clause shall be adjusted by the pit committee and mine foreman, and in case of their failure to agree, shall be taken up for settlement under the thirteenth section of this agreement.

In cases where the mine manager directs the placing of crossbars to permanently secure the roadway, then, and in such cases only, the miner shall be paid at the current price for each crossbar when properly set.

The above does not contemplate any change from the ordinary method of timbering by the miner for his own safety.

17. The operators will recognise the pit committee in the discharge of its duties as herein specified, but not otherwise; and agree to check off union dues, assessments, and fines from the miners and mine labourers, when desired, on proper individual or collective continuous order, and furnish to the miners' representative a statement showing separately the total amount of dues, assessments, and fines collected. When such collections are made, card days shall be abolished. In case any fine is imposed, the propriety of which is questioned, the amount of such fine shall be withheld by the operator until the question has been taken up for adjustment and a decision has been reached.

18. The operators shall have the right in cases of emergency work or ordinary repairs to the plant to employ in connection therewith such men as in their judgment are best acquainted with and suited to the work to be performed, 
except where men are permanently employed for such work. Blacksmiths and other skilled labour shall make any necessary repairs to machinery and boilers.

19. The erection of head frames, buildings, scales, machinery, railroad switches \&c. necessary for the completion of a plant to hoist coal, all being in the nature of construction work, are to be excluded from the jurisdiction of the United Mine Workers of America. Extensive repairs to or rebuilding the same class of work shall also be included in the same exception. The employees thereon to be excluded, as above, when employed on such work only.

20. When any employee absents himself from his work for a period of two days, unless through sickness or by first having notified the mine manager and obtained his consent, he may be discharged.

21. (a) Except at the basing point, Danville, the differential for machine mining throughout the state of Illinois shall be 7 cents per ton less than the pick-mining rate. It being understood and agreed that the machine-mining rate shall include the snubbing of coal either by powder or wedge and sledge, as conditions may warrant, where chain machine is used; but it is understood that this condition shall not apply where two men have and work in one place only in the same shift, except at the option of the miner; and it shall also be optional with the miner which system of snubbing shall be followed. The division of the machine-mining rate shall be fixed in joint subdistrict meetings.

(b) The established rates on shearing machines and air or electric drills as now existing shall remain unchanged during the ensuing year.

22. Any underground employee not on hand so as to go down to his work before the hour for commencing work, shall not be entitled to go below, except at the convenience of the company. When an employee is sick or injured, he shall be given a cage at once. When a cage-load of men comes to the bottom of the shaft who have been prevented from working by reason of falls or other things orer which they have no control, they shall be given a cage at once. For the accommodation of individual employees less than a cage load, who 
have been prevented from working as above, a cage shall be run mid-forenoon, noon, and mid-afternoon of each working day: Provided, however, That the foregoing shall not be permitted to enable men to leave their work for other than the reasons stated above.

23. This contract is in no case to be set aside because of any rules of the United Mine Workers of America now in force or which may hereafter be adopted; nor is this contract to be set aside by reason of any provision in their national, State, or local constitutions.

24. All classes of day labour are to work full eight hours, and the going to and coming from the respective working places is to be done on the day hand's own time. All company men shall perform whatever day labour the foreman may direct. An eight-hour day means eight hours' work in the mines at the usual working places, exclusive of noon-time, for all classes of inside day labour. This shall be exclusive of the time required in reaching such working places in the morning and departing from same at night.

Drivers shall take their mules to and from the stables, and the time required in so doing shall not include any part of the day's labour; their time beginning when they reach the change at which they receive empty car's-that is, the parting drivers at the shaft bottom, and the inside drivers at the parting-and ending at the same places; but in no case shall a driver's time be docked while he is in waiting for such cars at the points named. The inside drivers, at their option, may either walk to and from their parting or take with them, without compensation, either loaded or empty cars, to enable them to ride. This provision, however, shall not prevent the inside drivers from bringing to and taking from the bottom regular trips, if so directed by the operator, provided such work is done within the eight hours.

The methods at present existing covering the harnessing, unharnessing, feeding, and caring for the mules shall be continued throughout the scale year beginning April 1, 1902; but in cases where any grievances exist in respect to same, they shall be referred to the subdistrict meetings for adjustment. 
When the stables at which the mules are lept are located on the surface and the mules are taken in and out of the mines daily by the drivers, the question of additional compensation therefor, if any, is to be left to the subdistricts affected for adjustment, at their joint subdistrict meetings.

25. Mission Field scale is referred to Danville subdistrict for adjustment.

26. The company shall keep the mine in as dry condition as practicable by lieeping the water off the roads and out of the working places.

27. The operator shall keep sufficient blankets, oil, bandages, \&c., and provide suitable ambulance or conveyances at all mines to properly convey injured persons to their homes after an accident.

28. The operator shall see that an equal turn is offered each miner, and that lie be given a fair chance to obtain the same. The check-weighman shall keep a turn bulletin for the turn-lieeper's guidance. The drivers shall be subject to whomever the mine manager shall designate as turn-keeper, in pursuance hereof.

In mines where there is both hand and machine mining, an equal turn shall mean approximately the same turn to each man in the machine part of the mine and approximately the same turn to each man doing hand work; but not necessarily the same to each hand miner as to each working with the machines.

29. There shall be no demands made locally that are not specifically set forth in this agreement, except as agreed to in joint subdistrict meetings held prior to May 1, 1902. Where no subdistricts exist, local grievances shall be referred to the United Mine Workers' State executive board and the mineowners interested.

The United Mine Workers of America, District No. 12.

W. R. Russeli, President.

T. J. Rininouds, Vice-President.

W. D. Ryan, Secretary-Treasurer.

The Illinois Coal Operator's' Association.

o. L. Gapisison, President.

E. T. Bent, Secretary.

Peoria : March 13, $190 \%$. 
I attest that this is a correct copy of the joint State agreement of coal miners and coalmine operators of Illinois for the year ending March 31, 1903.

Herman Justi, Commissioner.

\section{Indiana State Agreement.}

\section{Bituminous.}

Pursuant to an agreement between the Coal Operators and United Mine Workers of America, of Illinois, Indiana, Ohio, and Pennsylvania, made at Columbus, Ohio, February 9, 1900, the price of mining for bituminous coal in the State of Indiana shall be eighty cents per ton of 2,000 pounds for screened lump coal, made over a standard screen, and forty-nine cents per ton of 2,000 pounds for run-of-mine. That further details in scale of prices for pick and machine mining in the State of Indiana for one year, beginning April 1, 1901, shall be as follows :-

\section{Pick Mining. \\ Yardage.}

In entries 7 to 9 feet wide . . . . . . . . . . 1.66

In entries 12 feet the price shall be five-eighths of regular price or $1.03 \frac{1}{2}$

Entries shall not exceed 12 feet; it being understood that this applies to entry work only.

\section{Breali-throughs.}

Break-throughs between entries shall be paid for at entry prices. Break-throughs between rooms, when sheared or blocked, shall be paid for at entry prices; but no breakthroughs shall be driven without the consent of the operators. Nothing herein shall interfere with the law governing breakthroughs.

Room Turning.

Room turning $\$ 4.00$

Room necks to be driven 12 feet in and widened at an angle of 45 degrees when so desired by the operator. Any distance in excess of above shall be paid for proportionately, 
but no room neck shall exceed 15 feet. When room necks are driven 12 feet wide, the price shall be five-eighths of regular price, or $\$ 2.50$.

Machine Mining.

In entries 7 to 9 feet wide $\quad . \quad$. $\quad . \quad$. $\quad . \quad$. $\quad$. $\quad .1 .19$

In entries 12 feet wide, five-eighths of price for narrow entries, or . $\quad .74$

Narrow work after punching machines shall be sheared when demanded by the operator. Narrow work after the chain machine must be done in a workmanlike manner.

\section{Breali-throughs.}

Break-throughs between entries, same as entry prices. Break-throughs between rooms shall be paid for at same price when similarly driven.

\section{Room Turning.}

Room turning

$\$ 3.00$

Room necks to be driven 12 feet in and widened at an angle of 45 degrees when so desired by operators. Any distance in excess of above shall be paid for proportionately, but no room neck shall exceed 15 feet. When room necks are driven 12 feet wide, price shall be five-eighths of regular price, or $\$ 1.87$.

\section{Day Worts for Punching Machines.}

Machine work, when paid for by the day, shall be for machine $\$$ runner . . . . . . . . . . . . 2.82 Helper • . . . . . . . . . . . . 2.25

Day Work, Chain or Cutter-bar Machine.

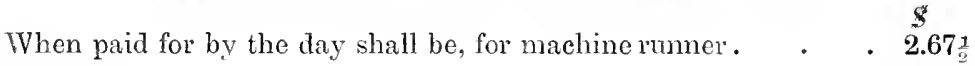
Helper . . . . . . . . . . . . $2.67 \frac{1}{2}$

Day work by machines shall apply only to opening new mines and defective work, such as hor'sebacks, \&c.

$$
\text { Price per Ton for Machine Mining. }
$$

For punching machine.-Screened lump-runner, 9 c.; helper, $8 \mathrm{c.}$; loading, shooting, and timbering, $45 \mathrm{c.}$; total, $62 \mathrm{c}$. 
Run-of-mine.--Runner, $5 \frac{3}{1}$ e.; helper, $5 \frac{1}{4}$ c.; loading, shooting, and timbering, $28 \mathrm{c.}$; total, $39 \mathrm{c}$.

For chain machine.-Screened lump-runner, 54 c.; helper, $5 \frac{1}{4}$ c.; loading, shooting, and timbering, $48 \mathrm{c.}$; total, $58 \frac{1}{2} \mathrm{c}$.

Run-of-mine.-Runner, $3 \frac{1}{4}$ c. ; helper, $3 \frac{1}{4}$ c. ; loading, shooting, and timbering, $30 \mathrm{c}$; t total, $36 \frac{1}{2} \mathrm{e}$.

Machine shovels shall be furnished by the operators, but when replaced, the old shovels must be returned, and, in case of careless breaking or destruction, the helper shall pay for the shovel so destroyed.

\section{Blacksmithing.}

Price of blacksmithing shall be $1_{\frac{1}{4}} \mathrm{c}$. on the dollar. Sharpening shall be done in a workmanlike manner, and men shall not have to wait for their tools.

\section{Day Labour.}

Inside day labour shall not be less than $\$ 2.25$ per day of eight hours, when men are employed, and track men and timber men shall receive $\$ 2.30$ per day of eight hours, and all outside day labourers working at the mines, excepting weighmasters, flat trimmer and dumper, who shall be regarded strictly as company men, shall be recognised as members of the United Mine Workers of America; provided that the present scale of prices now paid for ontside day labour shall prevail during the existence of this contract, together with present conditions and hours of labour, and provided further, that, in emergencies or in the absence of any regular employee, the right of the operator to employ men not members of the United Mine Workers for outside day labour shall not be questioned.

\section{General.}

1. When the coal is paid for mine-run, it shall be mined in as good condition as when paid for on a screened lump basis; and, when loaded on the miner's car, it shall, as nearly as possible, be free from slate, bone coal, or other impurities; and if it can be shown that any miner persistently violates 
the letter or spirit of this clause, he shall be discharged. Nor shall he load out an undue proportion of fine coal in any one car, but shall see that the fine coal is mixed with the large coal in such a way as to make a fair quantity of minerun coal. This provision for cleaning coal and penalty for failure also applies to screened lump coal.

2. The semi-monthly pay shall continue until the constitutionality of the law providing for weekly pay shall have been passed upon by the Supreme Courts of Indiana and of the United States.

3. The time of beginning work in the morning and the length of intermission at noon shall be considered a local question.

4. That the above scale is based upon an eight-hour workday; that it is definitely understood that this shall mean eight hours' work at the face, exclusive of the noon time; six days in the week, or forty-eight hours in the week, and that no local ruling shall in any way deviate from this agreement, or impose conditions affecting the same ; but any class of day labour may be paid at the option of the operator for the number of hours and fraction thereof actually worked at the hour rate, based on one-eighth of the scale rate per day; provided that, when men go into the mine in the morning, they shall be entitled to two hours' pay whether the mine works or not; provided further, that overtime of day labour shall be paid for at the same rate per hour.

5. Inside day work may be done upon idle days, and in case of emergency, on overtime.

6. It is agreed that if any difference arises between the operators and the miners at any time, a settlement shall be arrived at without stopping the work. If the parties immediately affected cannot reach an agreement themselves, the question shall be referred without delay to a board of arbitration, consisting of two operators, selected by the operator interested, and two miners, selected by the local union of the United Mine Workers of America involved. In the event of these four being mable to reach a decision, they shall select a fifth man, and the decision of the board so 
constituted shall be final, but no miner or operator interested in the difference shall be a member of such board.

7. The duties of the mine committee shall be confined to the adjustment of disputes between the mine boss or superintendent and any of the members of the United Mine Workers of America, working in and around the mines, except as hereinafter set forth in article 16 . In case they fail to agree, they shall proceed to adjust the trouble by the selection of an arbitration board as provided in article 6 of this agreement. The mine committee shall have no other authority, nor exercise any other control, nor in any way interfere with the operation of the mine; and, for violation of this agreement, the committee or any member thereof or mine boss or superintendent shall be discharged.

8. That under no circumstances will the operators recognise or treat with a mine committee or any representative of the United Mine Workers of America, during the suspension of work, contrary to this agreement.

9. The operator shall have the privilege of working a night shift for cutting coal with machines. All men so employed shall be paid 25 cents extra for each eight hours' work at night, in addition to the scale price per ton.

10. Work on driving entries and drawing pillars may be by double shift at the option of the operator.

11. This contract shall in no case be set aside because of any rules of any local union of the United Mine Workers of America, nor shall there be any rules made controlling or interfering with the operations of the mines except by the consent of the operators and miners.

12. Coal may be dumped as slowly as the operator may find necessary to thoroughly screen it, even if the car is brought to a stop, but it shall not be dumped in such a way as to throw the coal over the car door or unnecessarily break it.

13. Any miner knowing his place to be unsafe, shall protect same without delay and shall go into the mine for that purpose outside of regular hours and on idle days.

14. No restrictions shall be placed on the amount of coal 
which machines may mine, nor on the number of cars that any miner may load in any specified time.

15. The price of powder per keg shall be $\$ 1.75$. The miners agree to purchase the powder from their operators, provided it is furnished of standard grade and quality, that to be determined by the operators and expert miners jointly where there is a difference.

16. It is agreed that any hoisting engineer shall not be subjected to the interference or dictates of the mine committee or the local unions; but all differences between the engineer and his employer shall be adjusted by the officers of the United Mine Workers of America and the employer.

17. It is further agreed that the operators shall offer no objection to the check-off for the check-weighman and for dues for the Federation, provided that no check-off shall be made against any person until he shall have first given his consent in writing to his employer. This applies to all day work as well as miners.

J. Suith Talder, President.

P. H. Penna, Secretary.

Indiana Bituminous Coal Operators' Association. W. D. Van Horn, President.

Dist. No. 11, U.M.W. of A.

J. H. Kennedr, Sec'y-Treas.

Dist. No. 11, U.M.W. of A.

4. Онто.

Detailed Mining Scale for the Hocking Valley, the Basing District of Ohio.

Effective during the scale year, from April 1, 1900, to April 1, 1901, as adjusted and fixed by and betreen the Ohio State officials, United Mine Workers of America, and the operators of the said district, by their duly authorised representatives, at Columbus, Ohio, on Tuesday, February 20, 1900, and renewed and continued March 6, 1901, to be effective from April 1, 1901, to April 1, 1902. 


\section{Pick Mining Rate.}

Per ton of screcned lump coal

$\$$

Run of mine, 5-7 lump price .

Entries.

Dry entries per yard

Break-throughs in entries

Break-thronghs in roonis

Room turning.

Timber men, per day

Track layers, per day

Track layers' helpers, per day

Pipe men, per day .

Trappers, per day

Cagers, drivers, machine haulers, water haulers, and all other inside

day labour, per day . . . . . . . . . . 2.10

Dumpers and trimmers, per day . . . . . . . . $\quad 2.10$

Couplers, greasers, slack haulers, firemen, engineers, carpenter's, blacksmiths, cleaners, hostlers, and other outside day labour--Special prices according to nature of work.

\section{Machine.}

Cutting, by Jefrey styles of machine, in rooms, per ton . . $\quad .09$

Cutting, by Jeffrey styles of machine, in entries . . . . . . . . . .

Cutting, by punching machine, in rooms $\quad . \quad$. . . . . . . $.13 \frac{1}{2}$

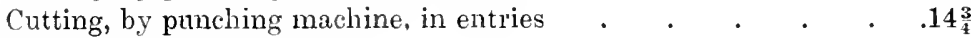

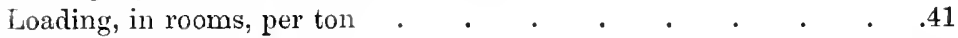

Toading, in rooms, with hand drilling, per ton . . . . . . . . . .

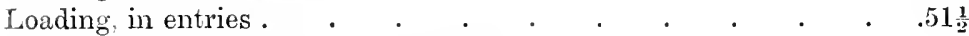

Loading, in entries, with hand drilling . . . . . . . . . $\quad .54 \frac{1}{2}$

Lnading, break-throughs, in entries . . . Entry price

Loading, break-throughs, in rooms . . . . . . . . . . . . . . . . .

Isoading, break-throughs, with hand drilling . . . . . . . . . . . . . $1 \frac{1}{4}$

Drilling by hand . . . . . . . . . . . . . . . . . . . . .

Drilling by machine . . . . . . . . . . . . . . . . . . . . . $02 \frac{1}{4}$

Room turning, cutter and loader. . . . Entry price

Rules and Conditions governing Hining in Hocking

District, from April 1, 1901, to April 1, 1902.

Turns.-There shall be no free turns allowed to either rooms or entries. The entries shall be driven as fast as operator's desire or conditions permit; but in no case shall 
entry miners be allowed more cars per week than room miners, and at least once each week the turn shall be made uniform throughout the mine for the time previously worked. If, however, the regular turn will not allow cars enough to drive the entries as fast as desired, the operators shall increase the number of miner's in each entry, so that, by giving to each the regular turn, the entries shall be driven as fast as two miners could do with full work.

If, however, the room men decline to take their place in the entries when requested to do so by the operator, then the entry men shall have free turns until the entries are driven their required length.

Limit on Nine Cars.-No limit of weight shall be placed on loading mine cars; and in case of loss in transit the company shall not be held responsible, except, where cars are broken by employees or where a wreck occurs, the average weight shall be made good by the company.

In order that miners cannot take advantage of this clause, the mine manager and committee, of any mine where complaint is made of loading cars over their capacity, shall mutually agree on a standard height of loading mine cars.

Check off.-The system of checking off for the United Mine Worker's' organisation remains in force and must be observed. Same to be checked off by per cent. of earnings.

Clay Veins.-Where clay veins, rolls in bottom or horsebacks exist, the price for removing same shall be determined between loader, mine boss, and mine committee.

Bottom, Sprags, dc.-All machines shall be fitted with front shoe not to exceed two and one-half inches in thickness, and the machine men be required to cut coal level and close to bottom; and in no case shall thickness of bottom exceed four inches, except in case of pots or other extreme variation; and all machine men leaving more bottom than above must lift the same, or it shall be lifted at their expense.

Where the mine boss or superintendent orders left greater thickness than four inches, the company shall take care of it; and where the bottom left is sulphurous and unmarketable the miner may call the attention of the mine boss to it and endeavour to arrive at an agreement for its removal or reten- 
tion. If the mine boss and miner fail to reach an agreement as to compensation or otherwise, the matter shall be submitted to the superintendent and mine committee for adjustment.

In case of sprags being left by a machine man, he shall be notified by loader, and if he refuse to remove the same, the loader shall remove the same and be allowed fifty cents for so doing, the said fifty cents to be deducted from the machine runner. And where any machine runner leaves six or more sprags in any one pay, he shall be removed from machine and his services be disposed of as deemed best by the general superintendent.

Rooms.-All rooms shall be thirty feet wide with two tracks in each room, where practicable. Where rooms have to be cut twenty-four feet wide or under eighteen feet, same shall be paid three cents per ton extra. Not to affect pillars or entries.

Each two men shall be given two rooms where practicable.

Blacksmithing.-Machine loader's not to be charged for blacksmithing.

Pick Mine Necks.-In opening rooms in pick mines, where narrow work exceeds eighteen feet before widening room, all in excess of eighteen feet shall be paid for at entry price.

Wet Places.-Where the mine boss and miner fail to agree as to whether the working place is wet and entitled to extra pay, it shall be referred to the committee and mine boss or superintendent, and, if adjudged wet, three cents per ton additional shall be paid.

Mine Idle on acconnt of Idle Men.-Where there are four men out of cutting or drilling, working after same machine or drill when work is commenced in the morning, and the same is not caused by accident, the mine shall remain idle that day.

But in no case shall the mine be stopped before the matter is brought to the attention of mine boss and mine committee, and only on their order.

Slate.-The company shall remove the slate from the 
working places of the miner ; and if the company fails after being notified, the miner shall be employed to remove such slate and be paid therefor at the price agreed upon between the mine boss and the miner, based on the price of inside day labour.

Double Shift Entry. - Twenty-five cents per yard shall be paid for driving double shift entries and break-throughs between entries.

Stops.-No stoppage shall take place at any mine on account of any grievance until the matter has been presented to the mine boss and superintendent, and an opportunity for adjustment permitted; and, failing to adjust, then the matter be referred to the officials and operators.

Clean Coal.-(Adopted at joint meeting held at Athens, Ohio, April 17, 1901.) No dock shall be taken for less than 100 pounds of dirt, unless it is apparent that dirty coal has been loaded intentionally; then 300 pounds of good coal shall be taken for 100 pounds or less.

For from 150 to 250 pounds of dirty coal, 700 pounds of good coal shall be taken.

For 250 or more pounds of dirty coal, 1,000 pounds of good coal shall be taken.

For the third dirty car of coal in the same day from the same working place, 1,500 pounds of good coal shall be taken; and if the man or men are found to have an average place by bank boss and committee, he, or they, shall be laid off for one day, or more, at the discretion of the mine boss and committee.

All good coal to be placed in the burial fund.

Weigh offices to be so arranged that check-weighmen can see chutes and railroad car.

Signed, as authorised at joint meeting, held at Athens, Ohio, April 17, 1901.

$$
\begin{aligned}
& \text { (EDWard Johnson, } \\
& \text { For Operators: Z. Wmilaus, } \\
& \text { J. M. Roan. } \\
& \text { (W. H. Haskins, President. } \\
& \text { For Miners: Michael Collins, Dist. Pres. } \\
& \text { Joseph Rrchards, Dist. Secy. } \\
& \text { Attest: F. S. Brooks, Secretary. }
\end{aligned}
$$




\section{Mining and Dead Work Scale for Pennsyluania: Pittsburg District.}

For the year beginning April 1, 1901.

\section{Pick Mining.}

Thin vein $1 \frac{1}{4}$ inch screened coal, per ton . . . . . $\quad .80$

Thick vein $1 \frac{1}{4}$ inch screened coal, per ton . . . . . $\quad$. $\quad .6680$

All clay veins 6 inches and less than 12 inches . . . . $\quad 2.20$

Anything orer 12 inches in all places at the rate per foot . $\quad 2.20$

When clay veins run at an angle, there shall be paid in all places while it continues, per yard $. \quad . \quad . \quad . \quad . \quad . \quad . \quad .55$

Anything 6 inches or less shall be considered a spar, for which shall be paid in all places . . . . . . . . 1.09

When the spar runs at an angle, there shall be paid additional per yard in all places . . . . . . . . . . .28

Room turning, neck not to exced 7 yards . . . . . . 3.03

Entry, single shift, per yard . . . . . . . . . . 1.64

Entry, double shift, per yard . . . . . . . . 1.94

Entry, treble shift, per yard . . . . . . . . . 2.24

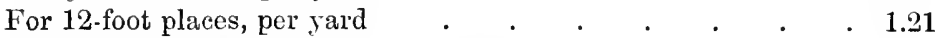

Break-throughs between rooms, per yard . . . . . 1.15

Break-throughs between entries, where slate is taken down, or comes down and has to be remored, per yard . . . . 1.64

Break-throughs between entries, where slate is not taken down, per yard . . . . . . . . . . . 1.15

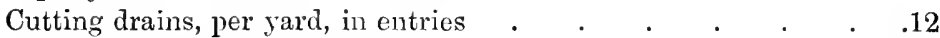

Ripping roof, per yard, in entries . . . . . . . . . . . . . . . .

Pick sharpening, on the dollar . . . . . . . . . . . . .

Ripping roof and entting drain in any place to be paid at above prices

Cross-cut entries, 45 degrees, extra per yard . . . . $\quad{ }^{20}$

Machine Mining.

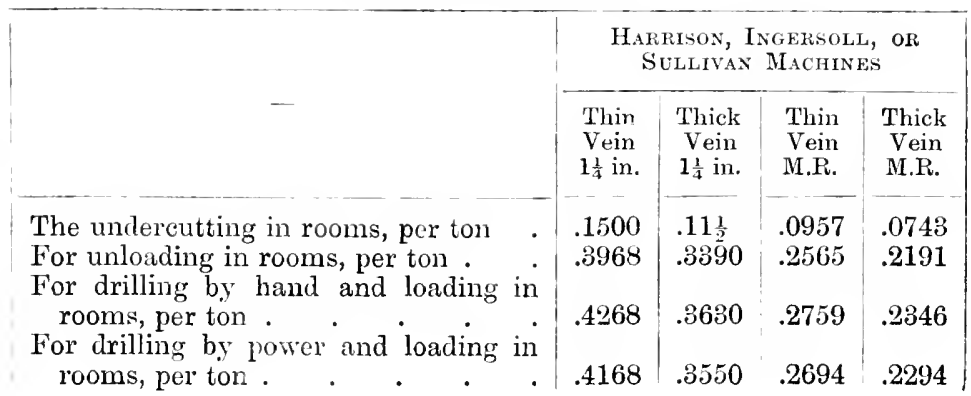


Machine Mining-continued.

For cutting in all narrow work, per ton and .2424 per yard, as vardage.

For drilling by hand and loading in entries, per ton . . . and .2121 per yard, as yardage.

For drilling by power and loading in entries, per ton . . . . and .2121 per yard, as yardage.

For loading in entries, per ton. and .2121 per yard, as yardage.

For loading and hand drilling in breakthroughs between entries, entry price to be paid.

For loading in break-thronghs between rooms, per ton. . .

For loading and hand drilling in breakthroughs between rooms, per ton .

Drilling by power drill, per ton . .

Drilling by hand drill, per ton .

\begin{tabular}{|c|c|c|c|}
\hline \multicolumn{4}{|c|}{$\begin{array}{l}\text { Harrison, Ingersoll, or } \\
\text { Sullivan Machines }\end{array}$} \\
\hline Thin & Thick & Thin & Thick \\
\hline Vein & Vein & Vein & Vein \\
\hline $1 \frac{1}{7}$ in. & $1 \frac{1}{2} \mathrm{in}$. & N.R. & \\
\hline .1542 & .1198 & .0997 & .0774 \\
\hline .5298 & .4454 & .3424 & .2879 \\
\hline .5198 & .4374 & .3359 & .2827 \\
\hline .4998 & .4163 & .3230 & .2690 \\
\hline .4631 & .3920 & .2993 & .2533 \\
\hline .4995 & .4212 & .3228 & .2722 \\
\hline .02 & .0160 & 0130 & .0100 \\
\hline .03 & .0240 & $.020_{0}$ & .0160 \\
\hline
\end{tabular}

For loading and cutting in room turning, entry price shall be paid.

Wherever narrow work prices are mentioned, on all machine cutting and loading, its equivalent may be paid in yardage, by mutual agreement.

Pick sharpening, loading after machines, $\frac{3}{4}$ cent on dollar, both thick and thin vein.

Loaders to receive 10 cents per yard in addition to above prices when driving entries double shift.

Price of entry on equivalent plan.

$$
\text { Air Machines-Thin Vein. }
$$

Cutter, entry price

Cutter, room price

.1542

.1500

Tons to one yard of entry

Entry yardage added .

'Total cost of cutting one yard of entry 
Loader, entry price $\quad . \quad$. $\quad . \quad$. $\quad . \quad$. $\quad .5298$

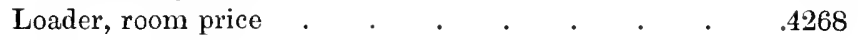

1030

Tons to one yard of entry . . . . . . . . . .

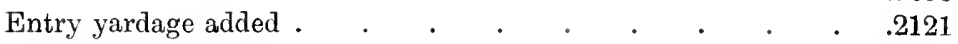

Total cost of loading one yard of entry $\quad . \quad \ldots \quad . \quad+\quad .5211$

Room Turning.

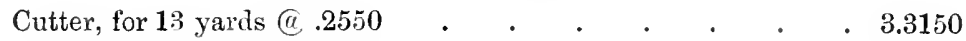

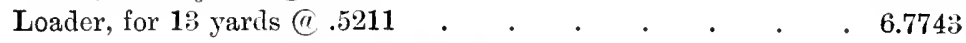

\section{Electric Machines-Thin Vein.}

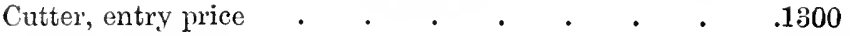

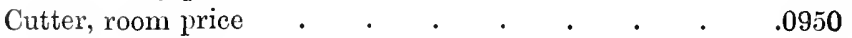

Tons to one yard of entry $\quad .0350$

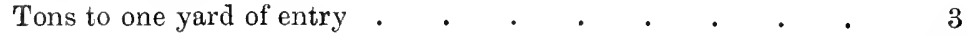

$\begin{array}{r}.1050 \\ \hline\end{array}$

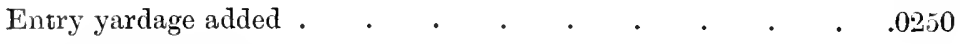

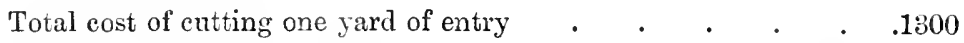

Loader, entry price . . . . . . . . 5400

Loader, room price $. \quad . \quad . \quad . \quad . \quad . \quad . \quad .4350$

.1050

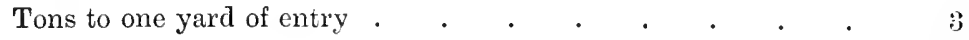

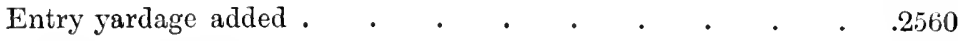

Total cost of loading one yard of entry . . . . . . $5 \overline{.5710}$

\section{Room Turning.}

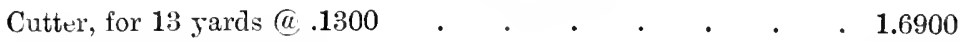

Loader, for 13 yards@.5710 . . . . . . . . $\quad .7 .4230$

Air Machines-Thick Vein.

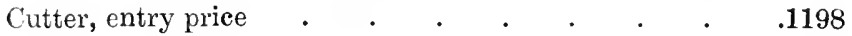

Cutter, room price $\quad . \quad$. $\quad . \quad . \quad . \quad . \quad .1150$

- 0048

Tons to one jard of entry . . . . . . . . . . 4

\begin{tabular}{rr}
0204 \\
\hline
\end{tabular}

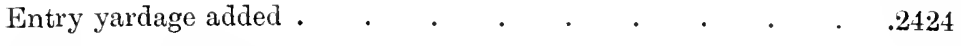

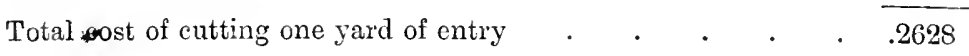


Loader, entry price .4454

Loader, room price . $\quad . \quad$. $\quad . \quad$. $\quad .3630$

Tons to one yard of entry . $. \quad . \quad . \quad . \quad . \quad \cdot \frac{.0824}{.3502}$

Entry yardage added .

Total cost of loading one yard of entry .2121 .5623

\section{Room Turning.}

Cutter, for 13 yards@.2628

Loader, for 13 yards (a) .5623

Electric Machines-Thick: Vein.

Cutter, entry price

Cutter, room price

Tons to one yard

Entry yardage added

Total cost of cutting one yard of entry

Loader, entry price . . . . . . . . . ${ }^{.4504}$

Loader, room price . $\quad . \quad$. $\quad . \quad$. $\quad .3680$

.0824

Tons to one yard of entry

Entry yardage added .

Total cost loading one yard of entry

.6062

\section{Room Turning.}

Cutter, for13 yards@.1550

Loader, for 13 yards@.6062

Equivalent Plan Tomnage.

All tomnage from entries and rooms to be paid at room work price.

Machine Dead Work-Thick and Thin Veins-With Harrison, Ingersoll, or Sullivan Machines.

Clay veins 6 inches and less than 12 inches

Of which the cutter receives 41 cents and the loader $\$ 1.21$.

Anything 12 inches or over, at the rate per foct of . .

Of which the cutter receives 41 cents and the loader $\$ 1.21$. 
When elay veins run at an angle across the room, there shall be paid while it continnes, per yard . . . . .

Of which the cutter receives 10 cents and the loader 30 cents.

Anything 6 inches or less shall be considered spar, which shall be

paid . • • • • • • • • • .

Of which the cutter receives 20 cents and the loader 60 cents.

When the spar runs at an angle, there shall be paid additional, per

yard .

Of which the cutter receives 6 cents and the loader 15 cents.

\section{Jeffrey, Link Belt, Morgan-Gardner, or any other Chain Machine.}

Clay veins 6 inches and less than 12 inches

Of which the eutter receives 26 cents and the loader $\$ 1.22$.

Anything 12 inches or over', at the rate of, per foot .

Of which the cutter receives 26 cents and the loader \$1.22.

When clay veins run at an angle across the room, there shall be paid while it continues, per yard

Of which the cutter receives 6 cents and the loader 30 cents.

Anything 6 inches or less shall be considered spar, for which shall be paid

Of which the cutter receives 13 cents and the loader 60 cents.

When the spar runs at an angle, there shall be paid additional, per yard

Of which the cutter receives 4 cents and the loader 14 cents.

All prices for narrow work and dead work in the thin vein shall apply for similar work in the thick vein.

\section{Inside Day IVage Scale.}

Track layers, per day

Track layer's' helper's, per day

Trappers, per day

Bottom cagers, per day

Drivers, per day

Trip riders, per day .

Water haulers, per day

Timber men, where employed, per day

2.10

Pipe men, for compressed air plants, per day

All other inside day labour, per day.

The hours of day labour at the mines to be from 7 o'clock a.m. until 12 o'clock noon, with one full hour for dinner, and from 1 o'clock p.m. until 4 o'clock p.m.

Wet entries to be agreed upon between mine boss and miners. 
On the question of thick slate in rooms and entries: All slate over 12 inches shall be considered 'thick slate,' and is to be paid for at a rate agreed upon between the miners and mine boss; and in case they camnot agree, then it shall be left to the superintendent and miners for adjustment.

It is especially agreed that the run-of-mine price shall be, in thin vein pick mines, .5171 cents per ton, and in thick vein pick mines, .4318 cen's per ton, and that two days' notice shall be given to miners when change is to be made from run-of-mine to screened coal. No mine to go on a runof-mine basis unless mutually agreed to by operator and miners.

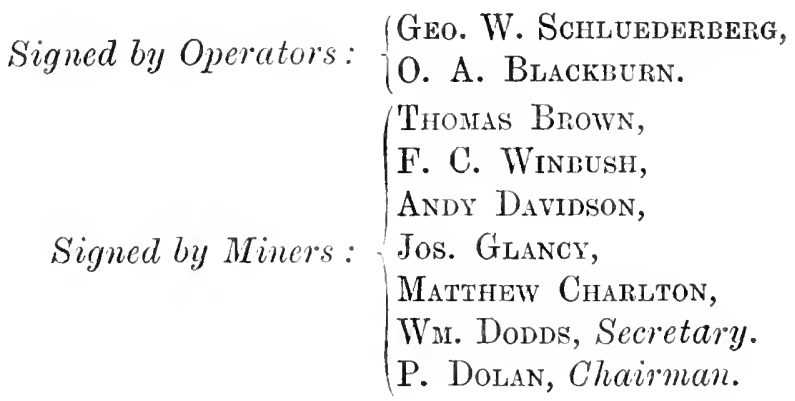

6. Concluding Passages from

The Report to the President on the Anthracite Coal Strike. By Carroll D. Wright, Commissioner of Labor.

\section{Departhent of Labor, Washington, D.C. : Jine 20, 1902.}

Sir,- I have the honour to submit herewith a report on the causes of and conditions accompanying the present controversy between the anthracite coal miners of Pennsylvania and the coal operators. I undertook this investigation in accordance with your verbal request of the 8 th instant.

The organic law of the Department of Labor provides that the Commissioner of Labor is 'authorised to make special reports on particular subjects whenever required to do so by the President or either House of Congress.' . . . 


\section{General Considerations.}

Much evidence has been offered to show the general condition of miners, their complaints and grievances, and the complaints and grievances of the operators. In a critical sense, these have all been referred to above, and the various appendices give them more fully. It is very clearly shown by the evidence that the miners have done something in the way of securing discipline, although they have disappointed the operators in such attempts. The miners claim that they have forced their members to accept discharge whenever they were wrong, and have ordered men back to work when the strike was not authorised by the labour union; that when the officers of the union have been able to see the manager of a company concerning any case and have been allowed to confer, they have almost invariably been able to arrive at an adjustment of the difficulty, but that where the manager refused to deal with the representatives of the union, there was no choice but to pass upon the matter according to the evidence of one side only, such evidence being taken as conclusive, and the officers being obliged to decide in favour of the men, who have preferred a wish not to work under existing conditions.

This, it is claimed, injures the corporations, because the results have not been based upon full evidence. The miners feel that the corporations, when they refuse to recognise the right of the unions to represent the men in adjusting any difficulty, ean not deny that the officers have the power to decide whether or not the employees shall strilie. They also state that if the operators will make an agreement with them, they will carry it out as far as it lies in their power to do so, but that without an agreement they are all the time quibbling as to conditions under which miners shall work. They feel that an agreement in writing will protect the corporations from unjust strikes, if they really desire such protection. The way it appears to the average workman is that the operators do not want an agreement that will bind them and prevent them from following their usual course.

On the other hand, the operators contend that no such 
agreement would have any binding effect upon the miners, and that it is ridiculous and foolish to undertake to make one; that they are interfered with constantly in their efforts to preserve order and good discipline.

All this shows, and proves clearly, that there is no confidence existing between the employees and their employers, and that suspicion lurks in the minds of everyone and distrust in every action on either side.

It is represented to me by reputable parties who have no interest in the mining business one way or the other that the chief difficulty lies in lack of organisation. This is shown by the existence of many practices in the management of coal mines which appear to be unwise, unfair, and calculated to work hardship. There are many prosperous miners in the coal region, and of course there is also, as in every industry, great destitution. The whole problem is an extremely complex one, and involves many practices that have been built up through long years. The mine owners too often have regarded the average miner as unreasonable, and likely to be unruly when occasion offered. The miner has come to regard the average owner as greedy and ready to do anything which will take advantage of him. Long-continued conditions on this basis of suspicion make the question one of great difficulty.

It would seem reasonable that if the men should be sure of steady work, or fairly steady work, they could well afford, perhaps, to take less wages, or even to continue on the present basis of payment. It is insisted by many that eight hours a day for six days in the week at less wages than they are now receiving would make the miners as prosperous a class of workmen as can be found in the United States.

Some of the miners have testified that if they can be paid by honest weight they do not care anything about the increase of wages. They say they would rather work nine hours a day with a decreased wage than on the old basis.

So there are all sorts of conflicting statements from both sides. Nevertheless, considering all the testimony that has been offered, and weighing it as carefully and as impartially as I can, and listening to the statements of operators, miners, 
capitalists, banker's, students, and others-to all of whom I am grateful for their generous assistance-I cannot help feeling that there are certain suggestions that are reasonable and just in the premises.

\section{Suggestions that seem reasonable and just.}

1. That the anthracite employees should organise an anthracite coal miners' union, in its antonomy to be independent of the United Mine Workers of America. The new union might, of course, be affiliated with the United Mine Workers and the American Federation of Labor; but in the conduct of all the affairs relating to the anthracite coal regions the new union should preserve its own autonomy and be financially responsible for its agreements.

2. That, considering all the facts relative to production, cost of coal at the mines, profits, freight traffic, \&c., it would be reasonable and just for the operators to concede at once a nine-hour day, but that this should be done for the period of six months as an experiment, in order to test the influence on production, with the guaranty that if production is not materially reduced thereby the agreement shall be made for a more permanent reduction of time.

3. That under a new organisation consisting of anthracite employees there shall be organised a joint committee on conciliation, composed of representatives of the operators and of the new union, to which all grievances as they arise shall be referred for investigation, and that when two-thirds of the committee reach a decision, that decision shall be final and binding upon both parties. (For practical illustration see Appendix H-'Contract of Bituminous Coal Miners and Operators.' ')

4. That the first duty of such joint board of conciliation shall be to enter upon a thorough examination and investigation of all conditions relative to mining anthracite coal, to question of weighing, to discipline, to wage scales, and to all matters that now form the burden of the complaints and grievances of both operators and miners; such investigation

1 This is the Illinois State Agreement, printed above in Appendix IV. 2. 
or examination to be made through the employment of experts to be selected by the joint committee; the results of such investigation not to be considered in the nature of an award of a board of arbitration, but as verified information on which future contracts can be made.

5. That whenever practicable and where mining is paid for by the ton, and until the joint committee referred to shall have made its report, coal shall be paid for by the ton and be weighed by two inspectors, one representing the operators and one representing the men, each side to pay its own inspector.

6. That there shall be no interference with non-union men.

7. That, whenever practicable, collective bargains shall be made relative to wages, time, and other conditions, under rules to be established by the joint committee referred to.

The proposition has been made that with the experience of the past the operators, in agreement with the miners, might establish a miform or fixed percentage of deduction from all coal mined as representing, on the average, the impurities, the result of which would be that every miner would know that a certain fixed percentage is to be deducted from the coal mined without reference to its purity; that such a rule, while it would be unfair and absurd in some cases, would be generous in others, and thus an understanding reached which would avoid all the irritations which now accompany the subject of weighing and the deduction for impurities. The question is full of difficulties, and it may not be possible to crystallise the proposition into a fixed rule; but it may be worth consideration by a joint committee such as has been suggested.

The conclusions stated above, Mr. President, seem to me, in the light of all the evidence that has been furnished me, to be reasonable and just, and should they be adopted, with some modifications, perhaps, here and there, they would lead to a more peaceful and satisfactory condition in the anthracite coal regions. They may not lead, even if adopted fully, to perfect peace nor to the millennium; but I believe they will help to allay irritation and reach the day when the anthracite coal rogions shall be governed systematically and in accord- 
ance with greater justice and higher moral principles than now generally prevail on either side.

I am, Mr. President, very respectfully, your obedient servant,

$$
\text { Carroll D. Wright, Commissioner. }
$$

The Priesident.

[Note.--This is to be carefully distinguished from, but compared clause by clause, with, the Report of the Anthracite Coal Strike Commission subsequently appointed by the President. The Awards of that Report are printed in Appendix VII.] 
V. IRON AND STEEL IN GREAT BRITAIN: RULES OF CONCILIATION BOARDS, SLIDING SCALES, ‥

1. Ruthes of the Minland Iron and Streel Wages Board. Revised and adopted at a Mecting of the Board held at Quecn's Hotel, Birmingham, Februmy 26, 1894.

1. The title of the board shall be The Midland Iron and Steel Wages Board.'

2. The objects of the board shall be to discuss, and, if necessary, to arbitrate on wages or any other matters affecting the respective interests of the employers or operatives, and by conciliatory means to interpose its influence to prevent disputes and put an end to any that may arise.

3. The president shall be a person of position not connected with the iron trade, chosen by the board, whose duty it shall be to attend at special meetings, npon being requested by the board to do so. He shall talie no part in the discussions, beyond asling for an explanation for the guidance of his own judgment, and if no settlement can be made, he shall give his adjudication.

4. The board shall consist of one employer and one operative representative from each works joining the board. Where two or more works belong to the sume proprietors, each works may claim to be represented on the board.

5. The employers shall be entitled to send one duly accredited representative from each works to each meeting of the board.

6. The operatives of each works shall elect a representative by ballot, at a meeting to be held for the purpose, on such day or days as the standing committee may fix, in the month of December in each year, the name of such representative, and of the worlis he represents, being given in to the secretaries, on or before January 1 next ensuing. 
The secretaries shall. in the month of Norember in each rear. issue a notice to each worlis connected with the board, requesting the election of representatives in the month of December, and shall supply the requisite forms.

7 . If any operative representative die, or resign, or cease to be qualified by terminating his comection with the rorks he represents, a successor shall be chosen within one month, in the same mamer as is provided in the case of annmal elertions.

8. The operatives representatives so chosen shall continue in oftice for the calendar year immediately following their election. and shall be eligible for re-election.

9. Each representative shall be deemed fully authorised to act for the worlis which he represents. and the decision of a majority of the board-or in case of equality of rotes, of its chairman-shall be binding upon the emplovers and operatives of all works comnected with the board.

10. The chairman shall be appointed by the employers' section from among their body. The rice-chairman shall be appointed by the operatives section from among their body. A secretary shall be appointed by the employers, and a secretary shall be appointed by the operatives, and a treasurer and a professional anditor shall be appointed by the board. Either of the secretaries, the treasurer, or anditor maty be dismissed by a resolution of the respective bodies appointing them. subject to three months notice.

11. The board shall meet for the trinsaction of business in February of each rear : but. by order of the standing committee, the secretaries shall convene a meeting of the board at any time. The circular calling such meeting shall express, in general terms, the nature of the business for consideration.

12. At the annual meeting of the board a standing committee shall be appointed as follows:-The emplorers shall nominate 12 of their number, exclusive of the chairman; and the operatives 12 of their number, exclusive of the ricechairman.

If at a meeting of the board or standing committee any emplovers' representative, or any operatives representative, 
be absent, the employer's' secretary, or the operatives' secretary, shall vote for such absent member or members as the case may be.

The standing committee shall have power to fill up all vacancies in their own committee that may arise during the year.

13. The standing committee shall meet for the transaction of business prior to the yearly meeting, and in addition as often as business requires. The time and place of meeting shall be arranged by the secretaries in default of any special direction.

14. The chairman shall preside over all meetings of the board, and of the standing committee, except in cases that require the president. In the absence of the chairman, a temporary chairman shall be elected by the meeting.

15. All questions requiring investigation shall be submitted to the standing committee, or to the board, as the case may be, in writing, and shall be supplemented by such verbal evidence or explanation as they may think needful.

An official form shall be supplied to each representative, on which complaints can be entered. Either secretary receiving a complaint shall be required to forward a copy of the same to the other secretary, and the complaint shall be considered as officially before the board from the date of such notice.

16. All questions shall, in the first instance, be referred to the standing committee, who shall investigate and have power to settle all matters so referred to it, except a general rise or fall of wages, or the selection of a president, which shall be referred to a special meeting of the full board. In case the standing committee fails to agree, the question in dispute shall be submitted to the full board, and if not decided by the board, shall then be submitted to the president; but in all cases witnesses from the works affected may be summoned to attend and give evidence before the president in support of their case.

17. No case which the standing committee is called upon to deal with, or subject of dispute, shall be brought forward at any meeting unless notice thereof has been given to the 
secretaries seven clear days before such meeting; but this is not to apply to routine business or to matters the investigation of which may be considered necessary by the standing committee.

18. All votes shall be taken at the board and standing committee by show of hands, unless any member calls for a ballot.

19. When the question is a general rise or fall of wages, a board meeting shall be held, and in case no agreement can be arrived at, it shall be referred to the president, and his decision shall be final and binding on all parties.

20. The expenses incurred by the board shall be borne equally by the employers and operatives.

The two secretaries shall arrange for the collection of the contributions quarter by quarter, on June 30, September 30, December 31, and March 31, which shall be forthwith remitted to the treasurer through the works' offices, and it is expected that the employer's will allow their pay clerks to assist the operatives' representative in making the collection upon being furnished with a list of those desiring to contribute.

The employers' contribution shall be at the rate of one shilling and sixpence per quarter for each puddling, ball, and scrap furnace, three shillings for each mill, heating, and annealing furnace, and ten shillings for each open hearth, steel furnace, or converter per quarter.

The operatives' contributions per quarter shall be-for all puddlers (including level hands), shinglers, rollers, heaters, steel workers, and all other tonnage men, fourpence per man. Also all time men (including puddlers' underhands) receiving three shillings and sixpence and over per day, a contribution of fourpence per quarter; and all time men receiving under. three shillings and sixpence per day, twopence per quarter.

The banking account of the board shall be kept in the name of the treasurer, and all accounts shall be paid by cheques signed by him.

21. The sum of ten shillings shall be paid to each member of the board, both employers and operatives, for each day's attendance, and second-class railway fare both ways. 
22. The operatives' representative shall be paid for time necessarily lost in attending to difficulties at the works to which he belongs, upon a certificate signed by the vicechairman and the operatives' secretary, at the rate of $10 \mathrm{~s}$. for each shift so lost.

23. Should it be proved to the satisfaction of the standing committee that any member of the board has used his influence in endeavouring to prevent the decisions of the board or standing committee from being carried out, he shall forthwith cease to be a representative, and shall be liable to forfeit any fees which might otherwise be due to him from the board.

24. If the employers and operatives at any works not connected with the board should desire to join the same, such desire shall be notified to the secretaries, and by them to the standing committee, who shall have power to admit them to membership on being satisfied that these rules have been or are about to be complied with.

25. No alteration or addition shall be made to these rules except at the meeting of the board to be held in February in each year, and unless notice in writing, of the proposed alteration, be given to the secretaries at least one calendar month before such meeting. The notice convening the annual meeting shall state fully the nature of any alteration that may be proposed.

26. The standing committee shall have power to make, from time to time, such bye-laws as they may consider necessary, provided the same are not inconsistent with or at variance with these rules.

27. No suspension of work shall take place pending the decisions of the board or of the president.

\section{Instructions.}

The board earnestly invites the attention of all who belong to it to the following instructions:-

1. If any subscriber to the board desires to have its assistance in redressing any grievance, he must explain the matter to the operatives' representative of the works at which he is employed. Before doing so he must, however, have 
done his best to get his grievance righted by seeing his foreman, or the manager, himself.

2. The operatives' representative must question the complainant about the matter, and discourage complaints which do not appear tc be well founded. Before taking action, he must ascertain that the previous instruction has been complied with.

3. If there seem to be good grounds for complaint, the complainant and the operatives' representative must take a suitable opportunity of laying the matter before the foreman or works manager, or head of the concern (according to what may be the custom of the particular works). Except in case of emergency, these complaints shall be made only upon one day in each week, the said day and time being fixed by the manager of the works.

4. The complaint should be stated in a way that implies an expectation that it will be fairly and fully considered, and that what is right will be done. In most cases this will lead to a settlement without the matter having to go further.

5. If, however, an agreement cannot be come to, a statement of the points in difference shall be drawn out, signed by the employer's' representative and the operatives' representative, and forwarded to the secretaries of the board with a request that the standing committee will consider the matter. An official form, on which complaints may be stated, can be obtained from the secretaries.

6. It will be the duty of the standing committee to meet for this purpose as soon after the expiration of seven days from receipt of the notice as can be arranged, but not later than the first Thursday in each month.

7. It is not, however, always possible to avoid some delay, and the complainant must not suppose that he will necessarily lose anything by having to wait, as any recommendation of the standing committee, or any decision of the board, may be made to date back to the time of the complaint being sent in.

8. Above all, the board would impress upon its subscribers that there must be no strike or suspension of work. The main object of the board is to prevent anything of this 
sort; and if any strike or suspension of work take place the board will refuse to inquire into the matter in dispute till work is resumed, and the fact of its having been interrupted will be taken into account in considering the question.

9. It is recommended that any changes in the modes of working requiring alterations in the hours of labour, or a revision of the scale of payments, shall be made matter of notice, as far as possible, and of arrangement beforehand, so as to avoid needless subsequent disputes as to what ought to be paid.

\author{
Bendanin Hingley, Chairman. \\ Sanuel Harris, Vice-Chairman. \\ Daniel Jones, Employers' Secretary. \\ William Aucotr, Operatives' Secretary.
}

1A. Midland Iron and Steel Wages Board. SLIDING SCALE FOR THE REGULATION OF IRONWORKERS' WAGES. Prepared by the Sliding Scale Committee appointed October 8, 1889, and finally confirmed by the unanimons resolution of the Board, passed October 21, 1889. ${ }^{1}$

1. The employers have selected six firms, and the operatives six firms, as follows, whose books are to be examined by the accountants.

Chosen by the employers: (1) Messrs. T. U. Ratcliff \& Co. ; (2) The District Iron and Steel Company ; (3) Messi's. Roberts \& Cooper ; (4) Messrs. Lones, Vernon, \& Holden ; (5) Messrs. Pobert Heath \& Sons, Limited; (6) Messrs. John Bagnall \& Sons, Limited.

Chosen by the operatives: (1) Messrs. P. Williams \& Sons; (2) Messrs. George Adams \& Sons, Limited; (3) Messrs. John Bradley \& Co.; (4) Earl of Dudley; (5) Messrs. W. Barrows \& Sons; (6) Messrs. N. Hingley \& Sons.

2. The employers and operatives jointly appointed Messrs. B. Smith, Sons, \& Wilkie, accountants, of Darlington Street,

1 In clause 1 the names of the firms are those at present (March 1903) selected. 
Wolverhampton, as accountants for the purposes of the scale, and they are instructed

(a) To take out the weights and selling price of all classes of iron as rolled and delivered from the mills (excepting charcoal iron, cold rolled, or that which has been subject to any additional process, and steel sheets, scrap ends, and defective sheets) sold by the twelve selected firms, every two months, commencing with September and October, 1889, as the first bi-monthly period. This ascertainment shall regulate wages for the two months of December and January, and so on, as shown thus :-

The average net Selling Price

Two months ending

October 31, 1889.

December 31, 1889.

February 28, 1890.

April 30, 1890.

June 30, 1890.

August 31, 1890.

October 31, 1890.
Will regulate Wages for

Two months ending last Saturday in January, 1890.

$\begin{array}{rll}, & , & \text { March, } 1890 . \\ , & , & \text { May, 1890. } \\ , & , & \text { July, 1890. } \\ " & , & \text { September, 1890. } \\ \text { ", } & , & \text { November, 1890. }\end{array}$

(b) For this purpose, books or sheets are to be provided by the board for the private use of each firm, in which all sales as aforesaid are to be entered, and the selling expenses are to be shown under the following heads:-

i. Railway Dues, Freight, Insurance, \&c.

ii. Discount, $2 \frac{1}{2}$ per cent. being the usual amount for each payment in the district.

iii. Commission.

(c) The books or sheets shall be cast up at the end of each two months, showing totals of sales and expenses, from which the net average selling price of the total tonnage shall be ascertained.

(d) These books or sheets shall be examined by the accountant, by comparing them with the existing books of the firm.

(e) The accountant shall forward to the employers' and the operatives' secretaries certificates duly signed, showing the result of his examination, at least one week before the bi-monthly wages settlements. 
(f) The accountant to be so chosen and instructed shall give an undertaking in writing that he will under no circumstances disclose to any other person the details of the books he has examined.

3. The average selling price having thus been ascertained, the standing committee, consisting of the chairman and vice-chairman of the board, and the two secretaries, with two other members belonging to each section of the board, shall meet and declare the price of puddling per imperial ton, in the following manner.

(a) Puddlers' wages shall be one shilling and ninepence (one shilling and sixpence,-Resolution of July 31,1893 ) in excess of one shilling for each pound sterling per ton in selling price, and the fractional parts shall be regulated thus :-

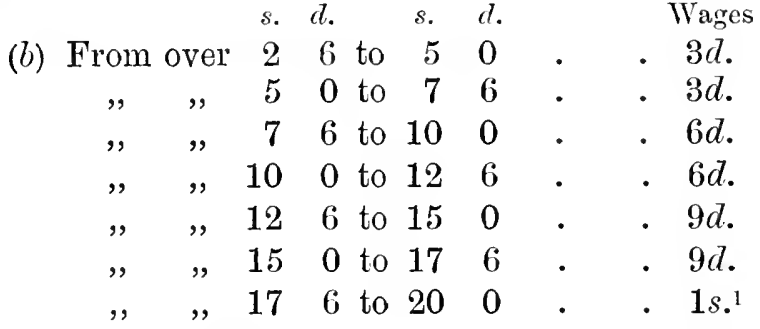

(c) Millmen's wages shall be advanced or reduced in the same way as heretofore, viz. :-For

1s. Puddling . . 10 per cent. Millmen.

$9 d$. , . . $7 \frac{1}{2},, \quad, \quad$,

$6 d . \quad, \quad . \quad 5,, \quad$,

$3 d$. , . . $2 \frac{1}{2},, \quad, \quad$,

(d) Such rates to include all claims in lieu of Northern extras.

4. The sliding scale thus established shall continue in operation until determined by notice from either side, in writing, of one calendar month, such notice to terminate at the close of one of the bi-monthly periods for which wages are regulated by this scale.

1 'The rate paid per ton between 1892 and 1899, in accordance with this scale, varied between $7 \mathrm{~s} .3 \mathrm{~d}$. and $9 \mathrm{~s}$. The list will be found in the Board of Trade Report on Standard Piece Rates and Sliding Scales (1900), 28. 
18. Midland Iron and Steel Wages Board.

A BI-MIONTHLY DECLARATION OF WAGES.

Meeting of the Standing Committee, 'Grand Hotel,'

Birmingham, Thursday, July 31, 1902.

Employers' Section-Sir B. Hinglex, Bart.. Chairman.

Mr. J. Lones . . (Messrs. Lones, Vernon, \& Holden).

" G. Macpherson . ( " P. Williams \& Sons).

" E. E. Cooper . ( " Tioberts \& Cooper).

" G. Adais . . ( " G. Adams \& Sons, Limited).

" E. PARhes . . ( " E. Parkes \& Co.)

" J. B. Lees . . ( " J. B. \& S. Lees).

" Burslen . . ( ", John Lysaght, Limited).

" J.F.CAY . . ( " Patent Shaft \& Axletree Co., Limited).

" Keen . . . ( " Guest, Keen, \& Co., Limited.

"G. Hatton . . ( " Earl of Dudley's Round Oak Co. Limited).

Colonel Patchetт ( $\quad$ The Shropshire Iron Co., Limited)

Operatives' Section-Mr. S. HARris, Vice-Chairman.

Mr. W. Chrines.

, J. HiLl.

"J. Callear.

"J. Pichards.

" E. Hollier.

$\because$ W. ALlen.
Mr. L. Chury.

"A. GoOdreId.

” J. O. KeLford.

"J. Rainbow.

"J. SмIтн.

" R. Pagett.

\section{$\left.\begin{array}{l}\text { Daniel Jones. } \\ \text { William Aucott, }\end{array}\right\}$ Secretaries.}

1. The minutes of the last meeting were confirmed and signed.

2. The accountants' certificate for May and June, 1902, was presented, of which the following is a copy:-

\section{- To the Midland Iron and Steel Wages Board.}

' 22 Darlington Street, Wolverhampton :

'July 25, 1902.

'Gentleuen,--We beg to report that we have examined the returns of sales of iron made by the twelve selected firms 
for the months of May and June, 1902, and have verified the same with their books.

'We certify the average net selling price to have been 67. $17 s, 9 \cdot 89 d$. per ton.

'Below is a statement of the different classes of iron sold, and the average net selling price of each :-

[Figures here omitted.]

'The following table shows the figures for the previous two months :-

[Figures here onitted.]

'We are, Gentlemen, your obedient servants,

'Benjamin Suith, Son, \& Wilkie, 'Chartered Accountants.'

In accordance with the sliding scale the rate of wages for puddling remains eight shillings and sixpence per ton, basis price, and millmen's wages in proportion, to commence August 4, and continue until Saturday, October 4.

\section{Sliding Scale.}

Mr. Harris stated that meetings of the operatives' representatives had been held to consider the disparity between the rate of wages for puddling in this district as compared with the North of England. The understanding for many years past had been that the Northern extras were worth $6 d$. per ton, and that had been paid in lieu of Northern extras. The scale on its own merits had not given that result; and although concessions had been made to remedy the difficulty the men had lost faith in the scale, and wished it to be modified or suspended, as it was from 1890 to 1893 , pending the settlement of the premium.

It was urged that since 1893 changes had taken place which affected the scale unfavourably for the men, the selected firms had been changed, and the newspaper reports of advances in the price of iron whilst the ascertainments showed a reduction, added to the difficulty. They did not ask 
to increase the premium to $1 s .9 d$. because the trade was not in a normal condition, and it might be found to give too high a result, but they asked for a suspension of the scale for a time, and to follow the Northern ascertainment, adding $6 d$. to the rate given by that scale.

The employers put in a statement showing the working of the scale since 1893, and with the concessions that had been made the men had only lost $3 d$. per ton over a period of two months. It was true the scale itself had not given that result, but recently all classes of iron had been included, which would give a slight improvement, and Northern prices tended to lower faster than Midland prices. It was not a time, considering the state of trade both in the Midlands and the North, to add to the difficulties of the employers, and whatever decision might be ultimately arrived at, it should not be hurried.

The operatives said they had no desire to take a false step by hurrying, and if the employers would assure them that if the next ascertainment did not give them the Northern rate for puddling, plus $6 d$., they would agree that the difference should be made up; they should be willing to allow the question to stand over until then.

It was then unanimously agreed-'That if the next ascertainment by the accountants does not give $6 d$. per ton above the North of England rate for puddling, the difference shall be made up.'

Mr. Jones reported that the accountants wished to know whether another firm would be selected in place of Messrs. P. Williams \& Sons for the examination of their books.

The operatives said it was their place to make the selection, as Messrs. P. Williams \& Sons were originally selected by them, but so far they had been unable to fix upon a firm, and therefore the accountants had better examine the books of the eleven firms, as they had done on a former occasion.

On the motion of Mr. Callear, seconded by Mr. G. Macpherson, this course was agreed to. 


\section{Messrs. I. Jentes d Sons (Minerva Ironworks).}

The firm had, in a correspondence with Mr. Jones, made complaint of the behaviour of a roller and his furnaceman, by neglecting their work.

Mr. Aucott had been to the works and investigated the case, and advised the roller that he was in the wrong, and had better make the best arrangement he could. Under Mr. Aucott's pleading, the firm decided to fine the roller 10 s., but to remit it back to him if he attended well to his work for a fortnight.

The firm wished the occurrence to be brought to the knowledge of the standing committee, which approred of what had been done.

Daniel Jones, Employer's' Secretary.
William AucotT, Operatives' Secretary.

2. The Bohrd of Conciliation and Arbitration for the Manufactured Iron and Steel Trade of tire North of ENGLAND.

AN ANNUAL PEPORT.

The Thirty-fourth Annual Meeting of the Board was held at the Station Hotel, Newcastle-on-Tyne, on Monday, January 26, 1903, Mr. WVilliam Whitwell in the Chair, and Mr. James Walsh in the Vice-Chair.

The following Peport of the Standing Committee and Statements of Account were submitted and adopted.

\section{Standing Committee's Report.}

The standing committee have to report that the number of works represented at the board is one less than six months ago, due to the closing of the Moor Works of the South Durham Steel and Iron Co. Ltd. The number now connected is 10 worlis owned by 8 firms.

The average number of operative subscribing members during the half-year has been 4,128. In the first half of 
1902 the number was 4,071 , the last six months thus showing an increase of 57 .

The financial statement for the past twelve months, duly audited by Messi's. Abbott \& Pugh, is submitted herewith, and shows as follows :-

\begin{tabular}{|c|c|c|}
\hline $\begin{array}{l}\text { Balance in hand, January } 1,1902 . \\
\text { Receipts during the year }\end{array}$ & $\begin{array}{l}6004 \\
. \quad 859\end{array}$ & $\begin{array}{ll}\ddot{8} & 2 \\
2 & 5\end{array}$ \\
\hline & $\mathfrak{\ell 1 , 4 6 3}$ & \\
\hline $\begin{array}{l}\text { Expenditure } \\
\text { Balance in hand, December } 31,1902\end{array}$ & $\begin{array}{r}953 \\
\cdot \quad 510\end{array}$ & \\
\hline & & \\
\hline
\end{tabular}

The standing committee have met four times since the half-yearly board meeting, and there have been three meetings of subcommittees appointed to deal with cases that have required investigation by a visitation of the works affected.

The following are the matters that have come before the standing committee:-

Consett Works.-Claim of enginemen and others at No. 4 cogging mill for an advance in wages in consequence of increased output.

Consett Works. - Claim of the men employed at the angle cogging mill for a revision of their rates.

Jarrow Works. - Claim of the operatives in the sheet mill to be paid their average day's earnings on the old mode of working, for the period they lave been under the new mode of working.

Jarrow Works.-Claim by the firm for reduction of rates paid in the $36 \mathrm{in}$. mill cogging mill, on the ground of the improved appliances provided.

West Hartlepool Works.-Claim of the firm for reduction in the wages of the soaking-pit firemen on the ground of the furnaces being now partly gas-heated.

General Wages. - Neither in the case of the works under the general sliding scaled, nor in the case of the steel-mill men at the works affected by the scale that applies thereto, has there been any change in wages during the past half-year. 
The usual tabular statement of the ascertainments for the purpose of the general sliding scale is appended:-

\begin{tabular}{|c|c|c|c|}
\hline Period & Tons & $\begin{array}{l}\text { Average net } \\
\text { Selling Price }\end{array}$ & $\begin{array}{l}\text { Effect upon Wages } \\
\text { under Sliding Scale }\end{array}$ \\
\hline $\begin{array}{l}\text { Two months ending-- } \\
\text { August } 31,1902 \\
\text { October } 31,1902 \\
\text { December } 31,1902\end{array}$ & $\mid\left[\begin{array}{c}\text { Figures } \\
\text { here } \\
\text { omitted. }\end{array}\right]$ & $\left\{\begin{array}{rrr}x & s . & d . \\
6 & 3 & 11 \cdot 03 \\
6 & 5 & 7 \cdot 36 \\
6 & 5 & 1.54\end{array}\right.$ & $\begin{array}{c}\text { No change } \\
, " \\
\text { ", }\end{array}$ \\
\hline
\end{tabular}

An event which it is believed will be of considerable interest to the members of the board was the visit to the United States in the autumn of last year of the 'Moseley' commission, for the purpose of inquiring into the industrial conditions and methods of that country, and this interest will doubtless be enhanced by the fact that the operatives' secretary of your board was selected to act on that commission as the representative of the British iron and steel trades.

The result of the investigations of this important delegation has not yet been made known, but the report which will be available to the public is awaited with more than usual interest by all comnected with the trades with which your board is more immediately concerned.

The past year has been chiefly marked by the decline in the shipbuilding industry, which has reacted seriously upon the manufacturing trade in plates and angles. It is to be hoped that the present depression may only be of a temporary character, and that ere long renewed activity of trade in this direction may be experienced.

In other departments trade has been on the whole fairly normal, though the continued high prices of raw material in relation to the depressed prices of the finished products leaves but small margin for competitive trading purposes.

Economy in manufacture, the avoidance of waste, the production of outputs to the fullest capacity of the machinery employed, are matters necessitating the urgent attention of all, in order to successfully hold our. own in the markets of the world.

The employer and operative members of the board may 
well take a legitimate pride in the influence exercised by their organisation in the direction of industrial peace and the avoidance of strikes-so disastrous to the general trade of the country. It may confidently be asserted that the principles of conciliation and arbitration represented by this board are finding more general acceptance in every branch of industry ; and your standing committee feel they are therefore warranted in the belief that with a more extended knowledge of these principles and methods, industrial warfare will speedily cease its destroying and retrograde influence upon all sections of trade.

Statement of Receipts and Expenditure for the twelve months ending December 31, 1902.

RECEIPT:

To Balance from 1901

To Wm. Whitwell \& Co., Ltd.

To Soutl Durham Steel \& Iron

Co. Ltch Malleable Works

Moor Works 49174

West Hartlepool Works . . $\quad 8114$

To Sir Theodore Fry \& Co., Ltd. . 601510

To Consett Iron Co., Ltd. • , 29I 506

To John Abbott \& Co.. Lt\}. . . 4172

To John Spencer \& Sons, Ltd. . $3310 \quad 6$

To Palmer's Shipbuilding \& Iron Co., Ltd.

To S. Trzack \& Co., Lt l.

$41 \quad 18 \quad 4$

To Interest on Deposit with N.P. Bank.
EXFENDITLRE.

$$
\text { \& s. } \text {.. \& s. } d \text {. }
$$

By Amonnt pain to Operatires:Attendance at Meet.

$\begin{array}{llrrr}\text { ings } & \cdot & 77 & 0 & 0 \\ \text { Lost time: } & : & 100 & 10 & 0 \\ \text { Witncsses } & \cdot & 40 & 15 & 0\end{array}$

y Amount paid to Employers:- $218 \quad 5 \quad 0$

Attendance at Meet.

ings . . . $\quad \begin{array}{llll} & 57 & 0 & 1\end{array}$

Witnesses: : : 1100

By Amount paid to Employers mader Pule ol to

$\begin{array}{lll}75 & 2 & 6\end{array}$

By Railway Fares-

Operatives . 3916 (

Employers . . 27180

By Secretaries' Salaries - - 67140

By , Travelling Expenses . $28 \quad 5 \quad 10$

By Postages, Telegrams and Office Expenses:-(Secretaries) 12198

(Representatives) $4 \begin{array}{rrr}4 & 5 & 0\end{array}$

By Printing and Stationery . $17 \quad 2 \quad 10$

By Office Rent . . . . $\quad 2000$

by Rooms for Meetings: . . . $\quad \begin{array}{rrr}6 & 0 & 6\end{array}$

By Reporting . . . . 5130

By Accountant's fee for getting out Certificates of average net selling prices

By Aurlitors' and Treasurers' Fees By N.P. Bauk for Receipt Stamps

By Balance

$£ 1,463 \quad 19 \quad 7$

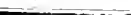

$\begin{array}{lll}125 & 0 & 0\end{array}$

$4+0$

$\begin{array}{lll}0 & 3 & 2\end{array}$

$£ 1,46310 \quad 7$

A uditel and found correet, January 24, 1903. B. A. AвBOTT,
T. B. PUgh, 
Statement showing the Amounts received by the Employer and Operative Representatives during the twelve months ending December 31, 1902 (Railway fares excluded).

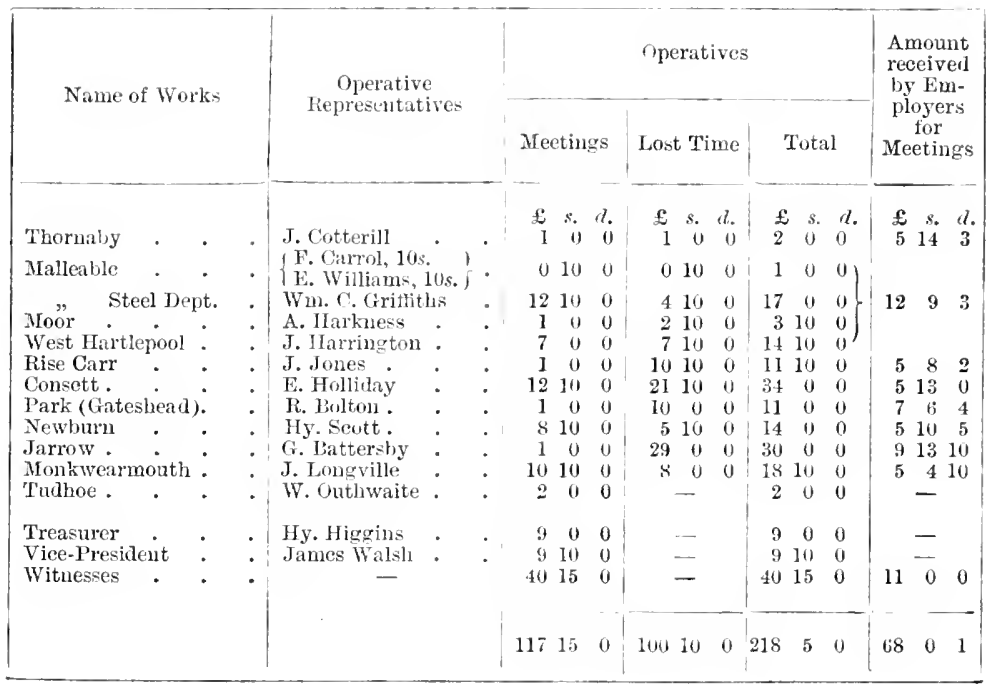

Election of Officers and Standing Committee.

The officers and standing committee were elected as follows:-Referee, Sin David Dale, Bart. President, Mr. Wx. Whitwelu. Vice-President, Mr. Jas. Walsh. Secretaries, Messrs. J. R. Winpenny and James Cox. Auditors, Messis. B. A. Авbott and T. B. Pugh. Treasurers, Messis. Willian Thachray and Henry Higgins, with power to attend board and standing committee meetings and to take part in discussions, but not to vote.

Standing (onmitee.-Employers.-Messis. C. J. Bagley, J. Reay, R. W. Davies, Geo. Ainsworth, Edward Towers, J. W. Spencer, Douglas Upton, W. Thackray, and Thomas Williams. (Mr. Philip Hopkins to have the right of attending in place of Mr. Reay, Mr. S. S. Horsfield or Mr. J. Heymer in place of $\mathrm{Mr}$. Ainsworth, Mr. R. B. Ferry or Mr. A. Fairbairn in place of Mr. Towers, Mr. James Davis or Mr. H. C. McBeath in place of Mr. J. IV. Spencer, Mr. Arthur J. While or Mr. A. Sopwith in place of Mr. Upton, and Mr. W. G. C. 
Wylde in place of Mr. Thackray.) Operatives.-Messrs. Wm. C. Griffiths, E. Holliday, H. Scott, J. Longville, and J. Harrington.

\section{Vote of Thanks.}

The best thanks of the meeting were accorded to the chairman for his conduct in the chair, and for his services to the board during the past year.

\section{William Whitwell, President. Janes WaLsh, Vice-President. \\ J. R. WinPENnY, \\ JAMES Cox, Secretaries.}

3. Rules of the Scottish Manufactured Iron Trade Conciliation and Arbitration Board. Amended and adopted by the Board on Jamuary 23, 1899, and aguin amended on January 30, 1902.

1. Title.-The title of the board shall be, "The Scottish Manufactured Iron Trade Conciliation and Arbitration Board.'

2. Objects. - The objects of the board shall be to discuss, and if necessary to arbitrate, on wages or any other matters affecting the respective interests of the employers or operatives, and by conciliatory means to interpose its influence to avert stoppages, prevent disputes, and put an end to any that may arise.

3. Constitution of Board.-The board shall consist of one employer representative and one operative representative from each works joining the board. Where two or more works belong to the same proprietors, each may claim to be represented at the board.

4. Representatives. - The employers shall be entitled to send one duly accredited representative from each works to each meeting of the board. The operatives of each works shall elect their representative to the board, who must be a subscriber to the board.

5. Election of Operative Representatives.--The secretaries shall, in the month of November in each year, issue a notice to each works connected with the board, requesting 
the election of a representative in the succeeding month of December. The employers will have the notices posted in their works, and will, if desired by the acting representative, appoint a person to assist at the election if more than one candidate be nominated. The notice will call a meeting of the operatives for such day or days in the month of December, and at such place or places as the standing committee hereinafter mentioned may appoint, when candidates shall be nominated. If only one person be nominated, he shall be considered to be duly elected. If more than one person be nominated, an election by ballot shall be held on an early convenient day, to be fixed by the acting representative and the operatives' secretary, the candidate receiving the largest number of votes to be declared duly elected. The acting representative shall on or before the first day of January next ensuing send to the secretaries the name of the representative so chosen and of the works he represents. The secretaries will supply all printed forms necessary for the election.

6. Term of Office.-The operative representative so chosen shall assume office at the next ensuing annual meeting of the board, and shall retain office until the succeeding annual meeting. Both old and new representatives shall be present at each annual meeting, but only the old representatives shall vote on the adoption of the annual report and accounts. This being done, they shall at once demit office, and be immediately succeeded by the new representatives. Riepresentatives shall be eligible for re-election.

7. Interim Elections.-If any operative representative die, or resign, or cease to be qualified, or terminate his comnection with the works he represents, a successor shall be chosen within one month, in the same manner as is provided in the case of annual elections, and shall remain in office over the same period as would the representative in whose room he was elected.

8. Representatives disqualified by Stoppage of Works; Committees to fill up Vacancies.-In case of the total stoplage of any works connected with the board, except from temporary causes, both employer and operative representa- 
tives shall, at the end of one month from the date of such stoppage, cease to be members of the board, and of any committee on which they may have been elected. Any vacancies resulting from this or any other cause shall be filled up by the committee affected.

9. Powers of Representatives.-Each representative shall be deemed fully authorised to act for the works which has elected him, and the decision of a majority of the board shall be binding upon the employers and operatives of all works connected with the board.

10. Board Meetings.-The annual meeting of the board attended by new and old members shall be held in January of each year, when the accounts for the previous year shall be submitted. By order of the standing committee the secretaries shall convene a meeting of the board at any time, giving at least seven days' notice. The circular calling such meeting shall state in general terms the nature of the business for consideration.

11. Election of Officers; Casual Vacancies.-At the annual meeting the new members shall elect an arbiter, a president, a vice-president, two treasurers, two secretaries, and two anditors, who shall continue in office till the corresponding meeting of the following year, but shall be eligible for reelection. All except the arbiter and secretaries shall be elected from the members of the board. The secretaries shall be appointed, one by the employers' representatives and one by the operatives' representatives, and woth shall be paid by the board. Neither of the secretaries shall be an employer or an employee of the trade. Any casual vacancies in the offices of treasurers or auditor's which may occur during the year may be filled up by the standing committee; and any casual vacancy in the office of employer's' or operatives' secretary may be filled up by the representatives on the standing committee of the employers or of the operatives, as the case may be.

12. Duties of Officers.-The president and vice-president shall be ex-officio members of all committees, but without a casting vote. It shall be the duty of the president to preside over all meetings of the board and of the standing com- 
mittee, except in cases that require the arbiter. In the absence of the president and vice-president a temporary chairman shall be elected by the meeting; but in no case, whoever presides, shall the chairman have a casting vote. The secretaries shall be appointed as paid officials of the board without power to vote; they may, however, take part in all discussions.

13. Appointment of Standing Committee.-At the annual meeting of the board a standing committee shall be appointed as follows: The employers shall nominate twelve of their number (not more than one from each firm), exclusive of the president (not more than six of whom shall be entitled to vote or take part in any discussion at any meeting of the committee), and the operatives six of their number, exclusive of the vice-president. Six to form a quorum.

14. Standing Committee Meetings.-The standing committee shall meet as often as business requires. The time and place of meeting shall be arranged by the secretaries, in default of any special direction by the board or the president and vice-president.

15. Powers of Standing Committee, of Board, and of Arbiter.-All questions, including any not settled at the works, shall, in the first instance, be referred to the standing committee, who shall investigate and have power to settle all matters so referred to them (except a general rise or fall of wages, which shall be referred to a special meeting of the board). In any case where the standing committee fails to agree, or its decision is not accepted by either party, the question in dispute shall be submitted to the board; and, if not decided by the board, it may then be submitted to the arbiter, whose decision in all cases submitted to him shall be final and binding on all parties.

16. System of Voting.-All votes at the board and standing committee shall be taken by show of hands. If at any meeting of the board either the employer representative, or the operative representative, of any works be absent, the other representative of such works shall not be entitled to vote.

17. Method of Procedure in Disputes.-Questions re- 
quiring investigation by the standing committee or the board shall be submitted in writing through the secretaries. Either secretary receiving a complaint shall forward a copy of the same to the other secretary, and the matter referred to shall be considered as officially before the committee from that date. Before any question be considered, an agreement of submission shall be signed by the employer and operative representatives of the works affected, and given to the secretaries, who shall bring the same before the committee. Forms for these purposes shall be supplied by the secretaries.

18. Witnesses may be Summoned.-The committee or the board, or the secretaries in their discretion, may summon from the works affected, witnesses to give evidence in any case submitted to them. Such witnesses to be paid by the board such allowances and expenses as the committee may direct.

19. Notrce required by Standing Committee.-No case referred to the standing committee, nor any subject of dispute, shall be considered at any meeting unless notice thereof has been given to the secretaries four clear lawful days before such meeting, but this is not to apply to routine business nor to matters the investigation of which may be considered necessary by the standing committee.

20. General Wages Questions.-When the question is a general rise or fall of wages, a board meeting shall be held; and in case no agreement can be arrived at, it shall be referred to the arbiter, and his decision shall be final and binding on all parties.

21. No Suspension of Work.-No suspension of work shall take place pending the consideration or settlement of any question in dispute.

22. Contributions to the Board; Bankers; Operators of Banking Account.-The sum of one penny per head per fortnight (which sum may be altered if found necessary) shall be deducted from the wages of all puddlers (forehand, levelhand, and underhand), bushellers, scrap furnacemen and assistants, shinglers and assistants, forge rollers and assistants, puddled-bar bankmen, cutters-down, heaters and assistants, rollers and all assistants, finished- 
bar bankmen, pig-iron wheelers, and tap or cinder wheelers, earning over three shillings per shift. Each firm shall pay an amount corresponding to the total sum deducted from the workmen. The contributions, along with the official forms to be supplied by the secretaries, shall be forwarded to the bankers (the National Bank of Scotland, Limited, Glasgow), within one week from the pay when the money is deducted from the operatives. The banking account of the board shall be liept in the name of the treasurers, and all accounts shall be paid by cheque signed by them.

23. Expenses of Board.-All expenses incurred by the board shall be borne equally by the employers and operatives.

24. Allowances to Members for Attending Meetings.The sum of ten shillings shall be paid to each member attending a meeting of the board, or of the standing committee. The sum of fifteen shillings shall be paid to each member attending a meeting of subcommittee. In addition, each member shall be allowed travelling expenses at the rate of three-halfpence per mile, and when an operative member is engaged on the night-shift following the day on which a meeting is held, he shall be allowed payment for a second shift.

25. Allowances to Representatives for attending to Grievances; Concurrent Allowances to Employers' Representatives. - The sum of $£ 210 \mathrm{~s}$. per annum shall be paid to each employers' and operatives' representative, as in full compensation for all time lost by him attending to grievances at the works with which he is connected. In the case of any representative who has held office during part of a year only, he shall receive a proportionate amount, corresponding to the time during which he has held office. In the case of any sums being in any way paid to operatives' representatives in excess of what is paid to employers' representatives (railway fares alone excepted), a sum equal to such excess shall concurrently be credited to the employers collectively.

26. Mcmbers preventing Decisions being carried out.Should it be proved to the satisfaction of the Standing Committee that any member of the board has used his influence in endeavouring to prevent the decisions of the board or 
standing committee from being carried out, he shall forthwith cease to be a representative, and shall be liable to forfeit any fees which might otherwise be due to him from the board.

27. Alteration of Rules.-No alteration or addition shall be made to these rules, except at the meeting of the board held in January in each year, and unless notice in writing of the proposed alteration be given to the secretaries at least one calendar month before such meeting. The notice convening the annual meeting shall state fully any alteration that may be proposed.

28. Power to make Bye-laus.-The standing committee shall have power to make, from time to time, such bye-laws as they may consider necessary, provided the same are not inconsistent with or at variance with these rules.

29. Works wishing to join Board.-If the employers and operatives at any works not connected with the board desire to join the same, such desire shall be notified to the secretaries, and by them to the standing committee, who shall have power to admit them to membership on being satisfied that these rules have been or will be complied with.

\section{Instructions.}

The board earnestly invites the attention of all who belong to it to the following instructions :-

[Then follow the same instructions as in the Rules of the North of England and Midland Boards. See above, p. 272.]

4. Rules of the Board of Conciliation and Arbitration for the Manufactured Steel Trade of the West of Scotland.

I. The title of the board shall be, 'The Board of Conciliation and Arbitration for the Manufactured Steel Trade of the West of Scotland.'

II. The object of the board shall be to arbitrate on wages or any other matters affecting the respective interests of the employers or operatives, and by conciliatory means to interpose its influence to prevent disputes and put an end to any that may arise. 
III. The board shall consist of one employer and one operative representative from each works joining the board. Where two or more works belong to the same proprietors, each works may claim to be represented at the board.

IV. The employers shall be entitled to send one duly accredited representative from each works to each meeting of the board.

$T$. The operatives of each works shall elect a representative by ballot at a meeting held for the purpose, on such day or days as the board may fix, in the montl of December in each year. At the same time and in the same manner they shall also elect a substitute representative, who shall attend all meetings in the absence, through illness or otherwise, of the representative; the names of the representative and substitute representative, and of the works they represent, being given in to the secretaries, on or before January 1 next ensuing.

VI. If any operative representative die, or resign, or cease to be qualified by terminating his connection with the works he represents, a successor shall be chosen within one month, in the same manner as is provided in the case of annual elections, and shall remain in office till date of next general election.

VII. The operative representatives so chosen shall continue in office for the calendar year immediately following their election, and shall be eligible for re-election.

VIII. In case of the total stoppage of any worlis connected with the board, both employer and operative representatives shall, at the end of one month from the date of such stoppage, cease to be members of the board and of any committee on which they may have been elected. Any vacancies so resulting from this or any other cause shall be filled up by the committee affected.

IX. Each representative shall be deemed fully authorized to act for the works which has elected him; and the decision of a majority of the board, or in case of equality of votes, of its referee, shall be binding upon the employers and operatives of all works connected with the board.

$\mathrm{X}$. 'The board shall meet for the transaction of business 
four times a year, in January, April, July, and October ; but the secretaries may, with the sanction of the president and vice-president, convene special meetings at any time to deal with matters of urgency. Seven days' notice shall be given of the date of such meeting; and the circular calling such meeting shall express in general terms the nature of the business for consideration.

XI. At the meeting of the board, to be held in January in each year, it shall elect a referee, a president, and vicepresident, two secretaries, two auditors, and two treasurers, who shall continue in office till the corresponding meeting of the following year, but shall be eligible for re-election. The president and vice-president shall be ex-officio members of all committees, but without casting vote.

XII. The president shall preside over all meetings of the board, except in cases that require the referee. In the absence of the president and vice-president, a temporary chairman shall be elected by the meeting; but in no case shall the chairman have a casting vote.

XIII. All questions requiring investigation shall be stated in writing to the board, and shall be supplemented by such verbal evidence or explanation as the board may think needful.

XIV. The employer and operative representative of the works affected shall each make out and sign a statement of the matters in dispute; and this shall be given to the board. In case of the board failing to agree, the question in dispute shall be submitted to the referee, who shall be requested to decide the same; but in all such cases witnesses from all the works affected may be summoned to attend and give evidence in support of their case.

XV. No subject shall be brought forward at any meeting of the board unless notice thereof be given to the secretaries seven clear days before the meeting at which it is to be introduced.

XVI. All votes at the board shall be taken by show of hands, unless any member calls for a ballot. If, at any meeting of the board, the employer representative or the operative representative of any works be absent, the other 
representative of such works shall not, under the circumstances, be entitled to rote.

XVII. When the question is a general rise or fall of wages, a board meeting shall be held, at which the referee may be invited to preside; and in case no agreement be arrived at, a single arbitrator shall be appointed, and his decision at, $\mathrm{or}^{\circ}$ after, a special arbitration held for the purpose, shall be final, and binding on all parties. The referee may, by special vote of a majority of the board, he appointed arbitrator.

XVIII. Any expenses incurred by the board shall be borne equally by the employers and operatives. The banking account of the board shall be kept in the name of the treasurers, and all accounts shall be paid by cheque signed by them.

XIX. The sum of ten shillings for each member of the board shall be allowed for each meeting of the board. This sum shall be divided equally between the employers and operatives, and shall be distributed by each side in proportion to the attendances of each member. In addition, each member shall be allowed second-class railway fare each way, and when an operative member is engaged on the night-shift following the day on which a meeting is held, he shall be allowed payment for a second shift.

XX. The operative representative shall be paid for time lost in attending to grievances at the works to which he belongs, at the rate of ten shillings for each shift actually and necessarily lost. Should he, however, lose more time than is reasonably necessary in the opinion of the manager, the latter shall fill up the certificate only for such amount as he considers due before signing it. Whaterer sum or sums in this or any other way be paid to operative representatives, in excess of what is paid to employer representatives, the amount of such excess shall concurrently be credited to the employers collectively. An account of attendances and fees paid to each representative shall be kept; and the secretaries shall call the attention of the board to any case where the cost of adjusting disputes at any works exceeds, in their opinion, a proper amount in proportion to the number of operatives employed.

XXI. Should it be proved to the satisfaction of the board 
that any member of the board has used his influence in endeavouring to prevent the decisions of the board from being carried out, he shall forthwith cease to be a representative.

XXII. If the employers and operatives at any works not connected with the board should desire to join the same, such desire shall be notified to the secretaries, and by them to the board, who shall have power to admit them to membership on being satisfied that these rules have been, or are about to be, complied with.

XXIII. No alteration or addition shall be made to these rules, except at the meeting of the board to be held in January in each year, and unless notice in writing of the proposed alteration be given to the secretaries at least one calendar month before such meeting. The notice convening the annual meeting shall state fully the nature of any alteration that may be proposed.

XXIV. The board shall have posver to make, from time to time, such bye-laws as they may consider necessary, provided the same are not inconsistent with, or at variance with, these rules.

\section{Bye-laws.}

Rule V. The secretaries shall, in the month of November in each year, issue a notice to each works connected with the board, requesting the election of representatives in the month of December, and shall supply the requisite forms. It is understood that the substitute representative shall only act, either in the works or at the board, in the absence of the representative.

Piule VIII. No section of men in any works connected with the board shall have power to sever their connection with same without first giving six months' notice of their intention to do so, and no employer shall have the power to remove any section of men from the jurisdiction of the board unless with the consent of two-thirds of its members. Should any section of men cease work and thus sever their connection with the board, they shall not again be allowed to become members without the consent of at least two- 
thirds of the board, and on such conditions as the board may decide.

Pule XIII. An official form shall be supplied to each representative, on which complaints can be entered. Either secretary receiving a complaint shall be required to forward a copy of the same to the other secretary; and the complaint shall be considered as officially before the board from the date of such notice.

Rule XVIIr. The sum of one penny per head per fortnight shall be deducted from the wages of each operative earning tro shillings and sixpence per day and upwards. Each firm shall pay an amount corresponding to the total sum deducted from the workmen. The contributions shall be forwarded on official forms, to be supplied by the secretaries, to the bankers (the Bank of Scotland, Glasgow), within one week from the pay when the money is deducted from the operatives.

The board earnestly invites the attention of all who belong to it, either as subscribers or as members, to the following instructions:-

[These are the same as in the Rinles of the North of England, Midland, and Scotch Manufactured Steel Board. See above, p. 272.]

4a. Foril of Stateuent of Case.

A copy of this statement to be sent to each of the secretaries of the board-Mr.W.H. Pearson, 23 Royal Exchange Square, Glasgow, and Mr. John Cronin, 144 West Regent Street, Glasgow; one copy to be lept by the employers' representative and one by the operatives' representative.

BOARD OF CONCILIATION AND ARBITRATION FOR THE MANUFACTURED STEEL TRADE OF THE WEST OF SCOTLAND.

Case from Works. Relative to 
We, the undersigned representatives of these works, having made inquiry into dispute which has arisen between the employers and employed, and which we are unable to settle, desire, in accordance with the rules and bye-laws, that the board should take the matter up, and with this view we hereby submit statement of the subject in dispute from each side.

Signed this day of 190 Employers' representative. Operatives' representative.

\begin{tabular}{|l|c|}
\hline Exployers' Statenent. & Operatives' Statemext. \\
\hline & \\
\hline
\end{tabular}

5. Rules of Procedure for the Bodrd of Conciliation established between the Owners of Blast Furnaces in Scotland and the Scottish Blastfurnacenien.

\section{Established April 13, 1900.}

1. Title.-The title of the board shall be "The Board of Conciliation for the Regulation of Wages in the Pig-Iron Trade of Scotland.'

2. Objects.-The board shall have for its object the regulation of furnacemen's wages. Furnacemen's wages shall, until August 1, 1901, be regulated in terms of schedule hereto annexed.

3. Constitution of Board; Election of Furnacemen's Representatives.-The board shall consist of a representative of the owners and a representative of the furnacemen from each of the pig-iron works in Scotland. The same person may act as representative for more than one work. The furnacemen's representative at each work shall be elected from among their own number by the furnacemen who contribute to the board in terms of rule 16 , and he shall cease to be qualified if he terminates his connection with the works. 
4. Chairman and Vice-Chairmon.-The chairman and vice-chairman shall be elected by the representatives to the board at the first meeting, the one being an owners' representative and the other a furnacemen's representative.

5. Place of Board Mlectings.-The meetings of the board shall be held in Glasgow or such other place as the board shall from time to time determine.

6. Interpretation of Terms.-.The constituents of the board, i.e. the owners or owner's' representatives and furnaceliren or furnacemen's representatives, are, for brevity, herein referred to as 'the parties.'

7. Election of Officials; Duties and Remuneration.The parties shall each elect a secretary to represent them in the transaction of the business of the board, also a treasurer and an auditor; and each party shall give written notice thereof to the secretary of the other party, and such secretaries, treasurers, and auditors shall remain in office until they shall resign or be withdrawn by the parties electing them. The secretaries shall attend all meetings of the board, and shall be entitled to take part in the discussions, but they shall have no power to move or second any resolution, or to vote on any question before the board, unless they are duly elected members of the board. The same party may be appointed secretary and treasurer. The board shall fix the remuneration of the secretaries, treasurers, and auditors.

8. Convening of Board Meetings-Minutes.-The secretaries shall conjointly convene all meetings of the board and take minutes of the proceedings, which shall be entered in ctuplicate books, and each of these books shall be signed by the chairman, vice-chairman, or other person, as the case may be, who shall preside at the meeting at which such minutes are read and confirmed. One of such minute-books shall be kept by each of the secretaries.

9. Requisitions to call Meetings.-The secretaries, on the written application of the chairman or vice-chairman and the secretary of either party, for an alteration in the rate of wages, for considering any question falling to be brought before the board in terms of rule 18, or for an 
alteration of these rules, shall call a meeting of the board within fourteen days, at such time and place as may be agreed upon. The application for the meeting shall state clearly the object of the meeting.

10. Chairman to preside at Board Meetings.-The chairman, or, in his absence, the vice-chairman, shall preside at all the meetings of the board. In the absence of both chairman and vice-chairman, a member of the board shall be elected by the majority to preside at that meeting. The chairman or vice-chairman, or other person presiding, shall vote as a representative, but shall not have any casting vote.

11. Procedure in Disputes; Nentral Chairman may be called in.-All questions as to general advances or general reductions in the rate of wages, and any question arising under rule 18, shall, in the first instance, be submitted to and considered by the board, it being the desire and intention of the parties to settle any such general advances or general reductions and such questions ly friendly conference if possible. If the parties cannot agree, then the meeting shall be adjourned for a period not exceeding fourteen days, to allow the matter to be discussed by the constituents of the two parties. In the event of a disagreement at the second meeting a neutral chairman may be called in to settle the matter, but only if both parties agree to that course. If it is agreed to call in a neutral chairman, he shall be nominated at the second meeting, or an adjournment thereof, and a third meeting of parties shall be held not later than fourteen days thereafter. The decision of the neutral chairman shall be final and binding on both parties.

12. Questions to be stated in Writing-Evidence.-All questions submitted to the board under rule 11 shall be stated in writing, and may be supported by such verbal, documentary, or other evidence and explanation as either party may submit, subject to the approval of the board.

13. System of Voting.-All votes shall be taken at the meetings of the board by show of hands. Each representative on the board shall have one vote for each work which he represents. If at any meeting of the board the representative 
of one of the parties for any work shall be absent, the other party's representative for such work shall have right to take part in the discussion, but he shall not be entitled to vote.

14. Expenses.-All expenses incurred by the board, including the remuneration of the secretaries, treasurers, and auditors, as the same shall be fixed by the board, shall be defrayed out of a fund contributed by the owners and furnacemen as provided by rule $\mathbf{1 6}$.

15. Allowances to Furnacemen's Represcntatives attending Mectings ; Concurrent Payment to Owners collectively.Each furnacemen's representative shall receive out of the funds of the board the sum of $10 \mathrm{~s}$. for each day occupied in attending meetings of the board, or of any committee appointed by the board, and in addition return railway fare from the place where the work which he represents is situated to the place of meeting. When the representative is engaged on the night-shift following the day on which the meeting is held, he shall receive the further sum of $10 \mathrm{~s}$. A sum equal to that which is paid to the furnacemen's representatives for attending each meeting (railway fares excepted) shall concurrently be credited to the owners collectively.

16. Contributions to Expenses Fund.-To provide a fund to meet the expenses of the board, the sum of one penny per fortnight shall be paid by all keepers, assistants, fillers, chargers, pig-lifters, gasmen, ammonia-worlss men, furnace labourers, and other's directly employed about the blast furnaces. The said contributions shall be collected by the owners at each work, and shall be paid by them into an account to be opened with the Clydesdale Bank, Limited, Glasgow. The owner's of each work shall concurrently pay into said account an amount equal to the total contributions of the furnacemen at each work. When the funds in bank amount to $300 l$. the contributions thereto may be suspended, to be resumed when the funds fall below $150 \mathrm{l}$.

17. Bankers-Accounts - Audit.-The bank account shall be kept in the name of the treasurers, and all accounts shall be paid by cheque signed by them. Proper books of account shall be kept by the secretaries, which shall be 
examined and certified by the auditors at the end of each year.

18. Freedom of Employment and Labour; No Collective Action to leave Employment until Dispute brought before Board.-The orners will employ union and non-union men impartially, and no union member or official shall use threats or violence to influence any other workman to join the union, who has conscientious objections against doing so. Every union workman who elects to work in any ironwork shall, on giving the usual notice, be free to leave the employment, but while he remains in the employment he shall work in harmony with the non-union men. In the event of friction arising between workmen from any cause, the parties reserve freedom of action; but before any collective action is taken on the part of workmen to leave the employment the matter shall be brought before the board, in terms of rule 11, and an attempt made to have it adjusted.

\section{Schedule veferred to.}

(1) Wages to August 1, 1900.-The present rate of furnacemen's wages shall be increased by 5 per cent. on the basis rates as from May 1, 1900, and the wage so fixed shall remain in force until August 1, 1900.

(2) Sliding Scale to regulate Wages.-Thereafter, and until August 1, 1901, wages shall be regulated by the average selling price of Scotch pig-iron warrants in the Glasgow market, and shall rise or fall 5 per cent. on the basis rates for every $4 s .6 d$. of rise or fall in the price of pig-iron as above, the wage fixed in article No. 1 hereof being understood to be the wage applicable to a selling price of Scotch pig-iron warrants over $75 s$. $8 d$., and not over $80 s .2 d$. per ton, but in no case shall the wages so to be fixed fall below a point 15 per cent. over the basis rates ruling at January 1 , 1899 , nor rise above a point 10 per cent. on basis rates over the wage fixed in article No. 1 hereof, and the labouring wage shall not fall below $3 s$. per shift for efficient furnacemen.

(3) Ascertainment of Average Selling Price.--The average selling price of Scotch pig-iron warrants shall be ascer- 
tained by two accountants chosen one by either party, or by one accountant chosen mutually, and shall be struck every three months, the ascertained price for each three months to regulate the wages for the succeeding three months. The daily average shall be the mean of the highest and the lowest price paid for the day, and the three months' average shall be the average of the total daily averages for the three months.

6. Agreement entered into Deceuner 7, 1897, Between the Cleveland Ironmasters' Association of the one part and the Representatives of the Blastfurnacemen employed at the Associated Works of the other part.

The wagres of all classes of men working blastfurnace shifts shall, from December 31, 1897, till the agreement be determined by either party giving to the other three calendar months' notice-which, however, may not be given before September 30, 1900-be regulated by the following sliding scale :-

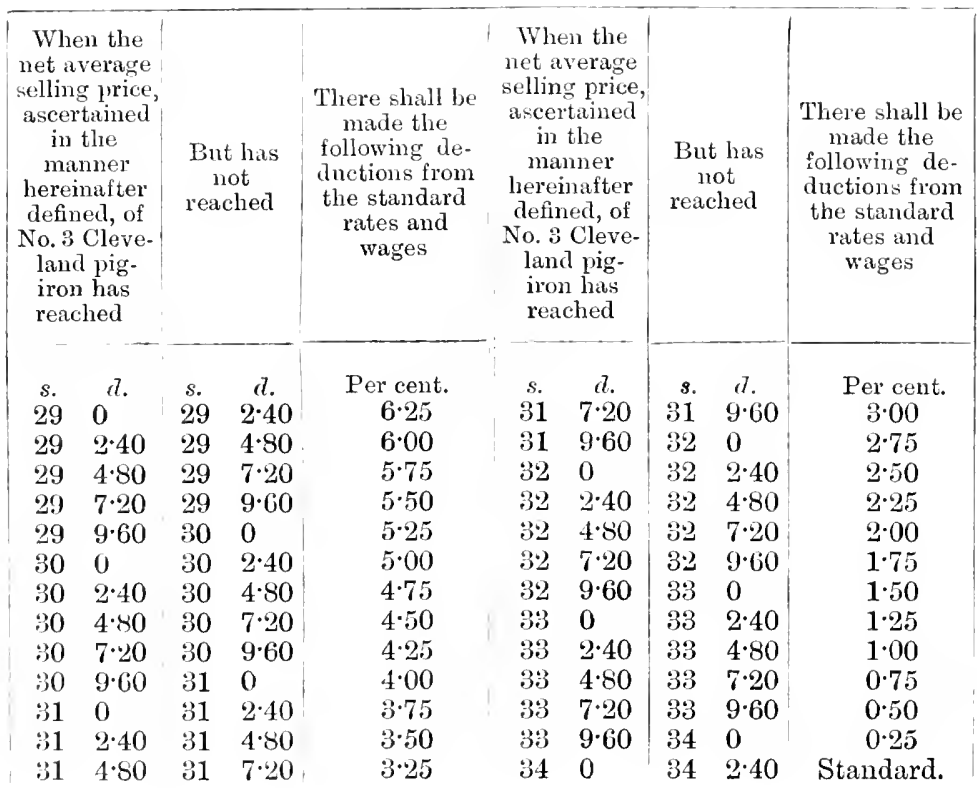




\begin{tabular}{|c|c|c|c|c|c|}
\hline $\begin{array}{l}\text { When the } \\
\text { net average } \\
\text { selling price, } \\
\text { ascertained } \\
\text { in the } \\
\text { manner } \\
\text { hereinafter } \\
\text { defined, of } \\
\text { No. } 3 \text { Cleve- } \\
\text { land pig- } \\
\text { iron has } \\
\text { reached }\end{array}$ & $\begin{array}{l}\text { But has } \\
\text { not } \\
\text { reached }\end{array}$ & $\begin{array}{l}\text { There shall be } \\
\text { made the } \\
\text { following addi- } \\
\text { tions to } \\
\text { the standard } \\
\text { rates and } \\
\text { wages }\end{array}$ & $\begin{array}{l}\text { When the } \\
\text { net average } \\
\text { selling price, } \\
\text { ascertained } \\
\text { in the } \\
\text { manner } \\
\text { hereinafter } \\
\text { defined, of } \\
\text { No. } 3 \text { Cleve- } \\
\text { land pig- } \\
\text { iron has } \\
\text { reached }\end{array}$ & $\begin{array}{l}\text { But has } \\
\text { not } \\
\text { reached }\end{array}$ & \begin{tabular}{|} 
There shall be \\
made the \\
following addi- \\
tions to \\
the standard \\
rates and \\
wages
\end{tabular} \\
\hline s. $\quad d$. & s. $\quad d$. & Per cent. & s. $\quad d$. & $s$. & Per cent. \\
\hline $34 \quad 2 \cdot 40$ & $34 \quad 4 \cdot 80$ & $0 \cdot 25$ & $42 \quad 4 \cdot 80$ & $42 \quad 7 \cdot 20$ & $13 \cdot 00$ \\
\hline $34 \quad 4 \cdot 80$ & $34 \quad 7 \cdot 20$ & 0.50 & $42 \quad 7 \cdot 20$ & $42 \quad 9 \cdot 60$ & $13 \cdot 25$ \\
\hline $34 \quad 7 \cdot 20$ & $34 \quad 9 \cdot 60$ & 0.75 & $42 \quad 9 \cdot 60$ & $\begin{array}{ll}43 & 0\end{array}$ & $13 \cdot 50$ \\
\hline $34 \quad 9 \cdot 60$ & $\begin{array}{ll}35 & 0\end{array}$ & $1 \cdot 00$ & 430 & $43 \quad 2.40$ & $13 \cdot 75$ \\
\hline 350 & $35 \quad 2 \cdot 40$ & $1 \cdot 25$ & - & & - \\
\hline- & - & - & 440 & $44 \quad 2 \cdot 40$ & $15 \cdot 00$ \\
\hline $\begin{array}{ll}36 & 0\end{array}$ & $36 \quad 2 \cdot 40$ & $2 \cdot 50$ & - & - & - \\
\hline - & & - & 450 & $45 \quad 2 \cdot 40$ & $16 \cdot 25$ \\
\hline 370 & $\begin{array}{ll}37 & 2.40\end{array}$ & $3 \cdot 75$ & - & - & - \\
\hline & - & - & $\begin{array}{ll}46 & 0\end{array}$ & $46 \quad 2 \cdot 40$ & $17 \cdot 50$ \\
\hline $\begin{array}{ll}38 & 0\end{array}$ & $38 \quad 2 \cdot 40$ & $5 \cdot 00$ & $77-$ & $15 \quad 0.10$ & $\overline{10.75}$ \\
\hline $39 \overline{0}$ & $39-2.40$ & $\overline{6 \cdot 25}$ & $\begin{array}{c}47 \quad 0 \\
-\end{array}$ & $\begin{array}{c}47 L^{2 \cdot 10} \\
{ }^{2}\end{array}$ & $\begin{array}{c}18 \cdot 75 \\
-\end{array}$ \\
\hline $\begin{array}{ll}39 & 2 \cdot 40\end{array}$ & $394 \cdot 80$ & $6 \cdot 50$ & $48 \quad 0$ & $48 \quad 2 \cdot 40$ & $20 \cdot 00$ \\
\hline $39 \quad 4 \cdot 80$ & $39 \quad 7 \cdot 20$ & $6 \cdot 75$ & & - & - \\
\hline $39 \quad 7 \cdot 20$ & $39 \quad 9 \cdot 60$ & $7 \cdot 00$ & $49 \quad 0$ & $49 \quad 2 \cdot 40$ & $21 \cdot 25$ \\
\hline $\begin{array}{ll}39 & 9 \cdot 60\end{array}$ & $40 \quad 0$ & $7 \cdot 25$ & - & - & - \\
\hline 400 & $40 \quad 1 \cdot 20$ & $7 \cdot 50$ & $50 \quad 0$ & $50 \quad 2 \cdot 40$ & $22 \cdot 50$ \\
\hline $40 \quad 1 \cdot 20$ & $40 \quad 2.40$ & $7 \cdot 75$ & - & - & - \\
\hline $40 \quad 2 \cdot 40$ & $40 \quad 3 \cdot 60$ & $8 \cdot 00$ & 510 & $51 \quad 2 \cdot 40$ & $23 \cdot 75$ \\
\hline $40 \quad 3 \cdot 60$ & $40 \quad 4 \cdot 80$ & $8 \cdot 25$ & - & - & - \\
\hline $40 \quad 4 \cdot 80$ & $40 \quad 6$ & 8.50 & 520 & $52 \quad 2 \cdot 40$ & $25 \cdot 00$ \\
\hline 406 & $40 \quad 7 \cdot 20$ & 8.75 & - & - & - \\
\hline $40 \quad 7 \cdot 20$ & $40 \quad 8 \cdot 40$ & $9 \cdot 00$ & 530 & $53 \quad 2 \cdot 40$ & $26 \cdot 25$ \\
\hline $40 \quad 8 \cdot 40$ & $40 \quad 9 \cdot 60$ & $9 \cdot 25$ & - & - & - \\
\hline $\begin{array}{ll}40 & 9 \cdot 60\end{array}$ & $40 \quad 10 \cdot 80$ & $9 \cdot 50$ & $54 \quad 0$ & $54 \quad 2 \cdot 40$ & $27 \cdot 50$ \\
\hline $40 \quad 10 \cdot 80$ & 410 & $9 \cdot 75$ & $\ldots-$ & & - \\
\hline 410 & $41 \quad 1 \cdot 20$ & $10^{\circ} 00$ & 550 & $55 \quad 2 \cdot 40$ & $28 \cdot 75$ \\
\hline $41 \quad 1 \cdot 20$ & $41 \quad 2 \cdot 40$ & $10 \cdot 25$ & - & - & - \\
\hline $41 \quad 2 \cdot 40$ & $413 \cdot 60$ & $10 \cdot 50$ & $\begin{array}{ll}56 & 0\end{array}$ & $56 \quad 2 \cdot 40$ & $30 \cdot 00$ \\
\hline $41 \quad 3 \cdot 60$ & $41 \quad 4 \cdot 80$ & $10 \cdot 75$ & - & - & - \\
\hline $41 \quad 4 \cdot 80$ & 416 & 11.00 & 570 & $57 \quad 2 \cdot 40$ & $31 \cdot 25$ \\
\hline 416 & $41 \quad 7 \cdot 20$ & 11.25 & - & - & - \\
\hline $41 \quad 7 \cdot 20$ & $418 \cdot 40$ & $11 \cdot 50$ & $58 \quad 0$ & $58 \quad 2 \cdot 40$ & $32 \cdot 50$ \\
\hline $41 \quad 8 \cdot 40$ & $41 \quad 9 \cdot 60$ & $11 \cdot 75$ & - & - & - \\
\hline $41 \quad 9 \cdot 60$ & $4110 \cdot 80$ & $12 \cdot 00$ & $\begin{array}{ll}59 & 0\end{array}$ & $59 \quad 2 \cdot 40$ & 33.75 \\
\hline $41 \quad 10 \cdot 80$ & 420 & $12 \cdot 25$ & - & - & - \\
\hline 420 & $42 \quad 2 \cdot 40$ & 12.50 & $60 \quad 0$ & $60 \quad 2 \cdot 40$ & $35 \cdot 00$ \\
\hline $42 \quad 2 \cdot 40$ & $42 \quad 4 \cdot 80$ & $12 \cdot 75$ & & & \\
\hline
\end{tabular}

And so on in either direction in the same ratio. 
The first ascertainment of price shall be for the three months of October, November, and December, 1897. Such ascertainment to take place as early as possible in January, 1898, and to regulate wages for January, February, and IIarch, 1898. And so on every three months. The changes in the wages shall take effect as soon in the month of January, April, July, or October (as the case may be) as the time of ascertaining the price will reasonably admit of, but not later than the 7 th of the month.

The net average selling price of No. 3 Cleveland pig-iron shall be confidentially ascertained by two properly accredited and certificated accomtants, one chosen by the irommasters and the other by the blastfurnacemen and at their respective charges, with whom there shall be associated any accountant who may be appointed by the North-Eastern Railway Company. Snch price shall be ascertained from the books of the following firms :-Messrs. Bolckow, Vaughan, \& Co., Limited ; Messrs. Bell Brothers, Limited; Messrs. Cochrane \& Co., Limited; Cargo Fleet Iron Co., Limited; Messrs. Wilsons, Pease, \& Co. ; Sir B. Samuelson \& Co., Limited ; and Edward Williams. The price shall be the actual net average invoice price at the works for each period of ascertainment.

Should any dispute arise as to the earrying out of any of these arrangements or as to the rates of wages at particular works, the question in difference shall be submitted to the decision of a committee comprising not more than six ironmasters, and not more than six blastfurnacemen, who, if they camnot agree, shall appoint an umpire to settle the matter; but no alteration shall during the currency of this agreement be made in the rates now prevailing at any of the works of the ironmasters parties hereto, unless such alteration is sought on the ground of the working conditions or the working appliances having changed.

If for any reason either party to this agreement desire to omit any of the firms above-named or to add thereto, the matter shall in case of difference be referred to the said committee.

It is agreed that $3 s$. per day shall be the minimum rate of wages for any workman employed to take blastfurnace shifts, 
and it is understood that this clause applies to spare furnacemen only.

\begin{tabular}{|c|c|c|c|c|}
\hline \multicolumn{2}{|c|}{ Works. } & \multicolumn{2}{|c|}{ Emplosers' Representatives. } & $\begin{array}{c}\text { Workmen's } \\
\text { Representa iives. }\end{array}$ \\
\hline Ayresome & . & . J. V. Cooper . & & . T. LAWRENCE. \\
\hline Acklam & - & . Hy. T. Allison & & . E. Rogers. \\
\hline Cleveland & . & $\cdot 1$ & & (E. Grahami. \\
\hline South Bank & $\cdot$ & & & J. Conner. \\
\hline Steel Works & Furnaces & - David Evans & - & J. Marney. \\
\hline Middlesbrous & gh & - & & J. Fiтсн. \\
\hline Lackenby & . & .1 & & John Hall. \\
\hline Cargo Fleet & . & - John G. Swan & . & J. SANDELL. \\
\hline Clarence & . & - Hugh Bell & . & Thos. McElhone. \\
\hline Tees Bridge & . & - Jos. E. Brooks & . & - Geo. Dickinson. \\
\hline Thornaby & 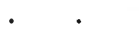 & - William Whitwell & & . W. Cork. \\
\hline Newport & . & - Francis A. E. Sauiuf & ELSON & . L. FENwICK. \\
\hline Consett . & . & . Geo. Ainsworth & . & Hy. Jones. \\
\hline Tees & . & . JOHN F. WILSON & . & Geo. Hurst. \\
\hline Clay Lane & . & . E. Намilton & ${ }^{\circ}$ & J. FoWLER. \\
\hline Redcar & . & - W. Eden Walker & e & J. HILDRICK. \\
\hline Jarrow & . & . F. W. Dick & $\theta$ & P. Treanor. \\
\hline Skinningrove & e & T. C. Hutchinson & . & W. WaLlace. \\
\hline
\end{tabular}

\section{The South Wales Tinplate and Sheet Mill Workers' Wages and Disputes Board.}

Rules of the Workmen's Section.

1. Name.-The name of this board shall be "The Tinplate and Sheet Mill Worker's' Wages and Disputes Board.'

2. Representation.-The representation shall be three from each society affiliated with the board, the voting power to be one for each delegate present. On all questions embracing a vital principle of wages or altered conditions of employment any society shall have the right of demanding a vote of the members of the societies aftiliated to the board. When such a vote is taken, the ballot boxes must be sealed, locked, or closed, and the unopened ballot boxes must be forwarded to an independent person appointed by the board who shall open and count the same on the date fixed, in the presence of one delegate from each society affiliated.

3. Officers.-The officers shall consist of a president, vice-president, secretary, and treasurer. 
4. Disputes.--In any grievance arising out of any department connected with the trade, no one society affiliated shall be allowed to hand in notices or stop work before first submitting such grievance for the consideration of the board.

5. Meetings.-The meetings of the board shall be held quarterly on the first Thursday in February, May, August, and November. The November meeting shall be the annual meeting.

6. All business for the agenda to be in the hands of the secretary of the board 14 days before the day of meeting. The agenda to be in the hands of the general secretaries of the unions affiliated 7 clear days before the date of meeting.

7. Emergency.-Any matter of importance, and not appearing on the agenda, to be dealt with subject to the decision of the meeting.

8. In cases of emergency the president and secretary shall have power to convene a special meeting.

9. Financial.--The expenses of management of the board shall be equally divided between the unions affiliated.

10. The minutes of all meetings shall be printed and sent to the unions aftiliated within 7 days from date of meeting, not less than 60 copies to be printed.

11. The remuneration for services rendered by the secretary shall be $12 l$. per annum.

12. Election of Officers.--All officers shall be elected every 12 months; nominations to be sent in 14 days before the annual meeting. 
8. Conciliation Board for the Ironfounding Indestril of the North-East Coast. Established October 22, 1894. BOARD AND OFFICERS, 1902.

Mr. S. Hunter, Chairman. Mr. J. LaIdLER, Vice-Chairman.

Employers' Representatives:

*Mr. D. S. MarJoribanks. Elswick Works, Newcastle. *Mr. P. Blair, Stockton-on-Tees.

*Mr. Ford S. Joblivg, Sunderland. Mr. J. IV. REED, Jarrow.

*Mr. R. Roger. Stockton-on-Tees.

"Mr. C. W. Taylor, South Shields. Mr. J. IV. Тномpson, Sunderland. Mr. A. Laing, Wallsend.

Mr. J. Walier, Newcastle.

Mr. G. O. Wallis, sunderland.

Employers' Secretary: MIr. James Robreson, Clarendon House, Clayton Street West, Newcastle.
Monlders' Representatives:

Mr. R. Brshop, Gateshead.

Mr. J. Liddele, Hartlepool. "Mr. Jajes Clasper, Stockton-on-Tees.

*Mr. Alf. Burn, Darlington.

*Mr. T. R. Johnstone, Sunderland. "Mr. R. Lawson, South Shields. Mr. G. Noble, Jarrow.

* Mr. T. Reid, Wallsend.

Mr. M. Waddington, Blaydon.

Mr. J. Laidler, Newcastle.

Mr. M. Stoves, Durham.

Moulders' Secretary: Mr. Artuur Henderson, Windsor Terrace, Park Lane, Darlington.

* Members of Standing Committee.

CONSTITUTION AND RULES.

1. Title.-The title of the board shall be 'The Board of Conciliation for the Ironfounding Industry of the North-East Coast.'

2. Parties. - The parties to the board are the Associated Employer's of the Tyne, Wear, and Tees and Hartlepool districts, and the Friendly Society of Iron Founders of England, Ireland, and Wales.

3. Constitution.--(a) The board shall consist of eleven employers and an equal number of moulder's' representatives.

(b) Each party shall elect its own representatives to act on the board, and they shall be deemed to have power to bind their respective constituents.

The representatives so elected shall from their own 
number elect five representatives to act on the standing committee named in Sub-section C.

(c) The standing committee shall consist of five employers and an equal number of moulders annually elected as aforesaid.

(d) The board shall from their number annually elect a chairman who shall be an employer, and a vice-chairman who shall be a moulder.

(e) In addition to the standing committee provided by Sub-section $\mathrm{C}$, the chairman and vice-chairman of the board shall be $c x$-officio members of the same, and when present at any meeting of the standing committee shall occupy the chair by virtue of their office.

( $f$ ) No matter or question before the board shall be submitted to vote unless by mutual agreement of both parties.

4. Objects. - The object of the board is to regulate general advances or reductions in the wages of the moulders; but any other general question may by common consent be brought before the board.

If any question arises which one of the parties considers it desirable to submit to the board, although the question may not be of a general nature, the same may be submitted by the secretary of the one party to the secretary of the other party to be considered; and if both parties agree, it may thereafter be brought before the board.

There shall be no stoppage of work in the nature of a strike or lock-out; and pending the decision of the board upon any question, all working conditions shall be those current at time of notice given.

5. Notice.-Four weeks' notice in writing, terminating on a total time day, shall be given by the secretary of one party to the secretary of the other party, of any question intended to be dealt with by the board.

6. Treatment.--All questions shall in the first instance be referred to the standing committee, who shall investigate and endeavour to settle the same. In the event of the standing committee being unable to settle a question, it shall, as early as possible, be referred to the entire board.

7. Meetings.-A meeting of the standing committee 
shall be called, after notice in writing, stating the business to be transacted thereat, given by the secretary or secretaries of one party to the secretary or secretaries of the other party. Such meeting shall be held not earlier than seven days, nor later than fourteen days, after receipt of notice of a question as provided in Rule 5. But the parties may mutually agree to alter time of meeting.

8. Quorum.- - Not less than three representatives for each party, inclusive of the chairman or vice-chairman of the board, shall constitute a quorum for a meeting of the standing committee; not less than six representatives for each party a quorum at any general meeting of the board.

9. Working Expenses.- Each party shall bear costs and expenses of its own representatives, and the other expenses incidental to the ordinary working of the board shall be borne equally by both parties.

10. First Board. - The first board shall be formed as early as possible, and continue in office till December 3, 1895. On that day the board shall meet to pass the accounts and close the business of the past year; and the new board shall then proceed to elect chairman and vicechairman for the next twelve months.

Names of representatives to act both on the board and the standing committee, together with name and addresses of secretaries, shall be handed in at the first and any subsequent annual meeting of the board. Any change in the rules or constitution of the board, of which at least four weeks' previous notice in writing has been given by one party to the other, may then be considered and disposed of as deemed most expedient.

11. Death, dc.-If any representative die, resign, $\mathrm{or}^{\circ}$ otherwise cease to be qualified, another shall be appointed within four weeks, and should any representative be unable to attend a meeting, a substitute may attend in his stead.

12. References.-Failing settlement by the board of any question referred to it by the standing committee, the same may, by common consent, be submitted to three disinterested 
gentlemen mutually approved by the board, the decision of whom, or of the majority of whom, shall be binding and conclusive. But if the board fail to agree in the choice of three gentlemen willing to act, each party shall elect its own referee, and the two referees so elected shall nominate a third to sit with them, and their decision, or the decision of the majority of them, shall in like manner be binding and conclusive.

13. Proceedings on a Reference.-Upon any submission or reference under the board, the referees shall arrange the place, day, and hour of hearing, and may adjourn as to them may seem most expedient. It shall be competent for either side to present its case by a legal adviser, but notice of intention so to do shall be given to the other party at least seven days before the hearing. It shall, however, not be obligatory upon the party receiving such notice to send the like to the other party.

Both parties are to obey notices of meetings issued by the referee, and to attend the same.

Any facts, considerations, or elements, may by mutual consent be agreed upon or eliminated from any reference.

The referees may examine any witness or witnesses on oath, or may allow any fact or facts to be proved by affidavit, provided that a copy of or the substance of an affidavit to be used at any reference shall be sent by the party intending to use it to the other party at least five clear days before the hearing day.

The cost and expenses of a reference shall be in the discretion of the referees, who may order that the same be paid equally by both parties, or that either party bear the whole or any particular part or parts of the entire costs.

Overtime Regulations for Tyne, Wear, and Tees Foundries, Agreed to on November 1, 1894.

The employers undertake to discountenance systematic overtime as much as possible.

Overtime to be paid for at the same rates as at present, but to be subject to the following restrictions:- 
New Work.-No man to be required to work more than sixty-five hour's in any one week, nor more than 230 hour's in any four weeks calculated from total time to total time.

Commercial Repairs. - No man to be required to work more than sixty-five hours per week, but systematic overtime to be avoided.

Break-downs in Plant or usual Shop Repairs.-According to previous custom, and therefore exempt from above restrictions, but overtime under this head to be discountenanced as much as possible.

\section{Definitions.}

For the purpose of computing overtime the following definitions are adopted :-

New Work.--That all work required in the construction of ships, engines, machinery, or other work appertaining to the engineering trade, or work required for a complete renewal of the same, shall be classed as new work. Converting old engines and supplying new engines to old ships shall be classed as new work.

Commercial Repairs.-That all work required in the repairs of ships, engines, machinery, or other work appertaining to the engineering trade that does not require a complete renewal, shall be classed as commercial repairs.

It is agreed that the above overtime regulations do not apply in case of emergency or necessity, such as the closing of a mould or casting, or when the work is in such an advanced state as to necessitate its completion without exposing it to the danger of being spoiled.

(Signed) A. Noble, Chairman, Conciliation Board.

T. R. Johnstone, Vice-Chairman.

T. Scarth, Arthur Henderson, $\}$ Delegates,

Friendly Society of Iron Founders. 


\section{VI.-IRON AND STEEL IN THE UNITED STATES: JOINT AGPEEMENTS, \&C.}

1. Statement concerning the Sliding Scale in the Iron and Steel Industriy and concerning Wages, 1837-97.

Presented by Mr. Garland, late President of the Amalgamated Association of Iron and Steel Workers of America, to the United States Industrial Commission, March 6, 1899.

THe diversities of wages and methods of payment to the working classes for labour of the present century are so complex that it would require much study of each trade and calling in each part of the country to get at the origin of the controlling cause of the present wages.

A part of the functions of organised labour is to arrange a specific price for labour for each position and the material or ware worked, and to curtail the supply of labour so far as possible except at this specified price. The demand for labour controls the employer to a large degree in the acceptance of the price established by organised labour; but if the trade or locality be unorganised, the natural law of supply and demand asserts full sway, and the necessities of starving humanity during times of depression and a surplus of labour alone forms the basis of minimum of wage, while in times of prosperity the necessity of the employer fixes the maximum. The simple idea of giving and getting employment at a stated sum per day, without specific agreement as to time and continuance, gives assurance to neither employer nor employee. The employer may attempt to reduce wages at any time that conditions or climatic changes are favourable, and may refuse to advance the wages when prosperity warrants him in doing so. On the other hand, the employee may demand better pay when conditions may not warrant it, or on the eve of a depression in prices. In fact, he is quite likely to do so, as he judges of ability to get more by past prosperity rather than by considering the future.

Fixing wages for a period of time by agreement, while 
being in advance of the system just described, inasmuch as it does not permit unwarrantable demands by either, does not give the possibility of sharing in prosperity by the workmen when the advanced price of the article warrants the payment of a better wage; and a system that does not give a share of prosperity to those who ereate the wealth of the land as well as those who hold the wealth, certainly cannot be recommended as the means of harmony.

Sliding scales, as they have been termed, are, in our estimation, a step in advance of any system now in use. The wages of the iron and steel worker have been based on and determined by this plan till 1866, and in fact the iron and steel workers claim to be the pioneers of the sliding-scale system. As a test of its efficiency, when fair employers are concerned, we recall to mind some of the most successful firms in the iron and steel trade that have been treating with labour in this way during all that period and who participated in drawing up the conditions of the first sliding scale.

Since its first adoption by the iron and steel workers, new features have been introduced from time to time, as it was necessary to adjust the system to new conditions as they arose. Under this system of sliding scale a rate of wages is agreed upon for each position, to be governed by the scale, and then a selling price for the material is selected as being a fair minimum price while that particular rate of wages is paid; a percentage of advance in the selling price of material is then listed as requiring a slight percentage of advance in the wages of the men in the several positions. The ratio of advance in wages is thus listed with the advance in material until the probable highest figure the material will sell at has been reached. A corresponding reduction of wages is agreed to as the material recedes in price. But a minimum price is agreed to as representing a stopping point in the decline in wages; and although the employer is free to sell his material lower than the minimum, he is not permitted a further reduction in wages. Certainly there can be no plan more equitable than one under which, when the price of material or goods goes up, the labourer's wages advance as well ; and if prices fall, he shares in the decline. But to adopt this 
system without establishing a minimum to its downward tendency shifts the effect described in disorganised trades and localities from advantage taken of necessity to advantage taken because of competition in trade, or, in other words, from wanton attack to competitive manipulation.

Experience in the sliding scale has taught that a cheapening in price may be the means of enhancing the profit of the employer and reducing the wages of labourers at one and the same time, unless proper safeguards are embodied. As an instance of this, the discovery of the great steel ore mines in the Masaba and other ranges of mountains in the North-west has had a very decided effect in reducing the price of both steel and iron. This is due to the fact that before these discoveries were made steel ore was not found in plenty and was expensive to mine and haul. These new mines were easily operated, and created an abundance of ore in market, introduced new and improved methods of handling, created competition in the hauling lines and built new ones, and gave to ore buyers a cheaper material. This enabled the manufacturers to convert this cheaper ore into pig iron and sell to the steel or iron rolling mills and yet retain their former margin or even a greater margin, as it suited them, to give to the consumer or not the benefit of the difference in the cost of ore. The same rule can be carried on by the manufacturer who purchases the pig iron and transforms it into steel or iron, as the case may be. The sliding scale, by reason of the cheapening of the article, would of necessity reduce wages to the minimum established. And were there none established, the wage-earner would be reduced to the extreme limit governed by the prosperity of the employer.

One of the advantages, and perhaps one of the chief advantages, of the sliding-scale system is the bringing together of employer and employee in conference and discussion of trade, duties, conditions, prospects, and ability to pay a fair wage. The intricacies and details of the sliding scale required full investigation into all these points and many other's. After all, it is the getting together of employer and employee with fair intentions that cultivates reason on both sides. . . 
Comparison of Scale, Selling Rate, and Material for Past Years.

\begin{tabular}{|c|c|c|c|c|c|c|c|c|}
\hline Year & Month & $\begin{array}{l}\text { selling } \\
\text { price } \\
\text { bar } \\
\text { iron } \\
\text { per ton }\end{array}$ & $\begin{array}{l}\text { Pluk- } \\
\text { dling } \\
\text { rates }\end{array}$ & $\begin{array}{c}\text { Bar } \\
\text { mill } \\
\text { heating } \\
\text { aud } \\
\text { rolling }\end{array}$ & $\begin{array}{l}\text { Selling } \\
\text { price } \\
2 \pm(6 . \\
\text { sheet }\end{array}$ & $\begin{array}{l}\text { Rolling } \\
\text { price } \\
24 \mathrm{G} \text {. } \\
\text { sheet }\end{array}$ & $\begin{array}{c}\text { Tin } \\
\text { plate } \\
\text { box IC, } \\
\text { full } \\
\text { weight }\end{array}$ & $\begin{array}{l}\text { Rolling } \\
\text { IO, } \\
\text { full } \\
\text { weight }\end{array}$ \\
\hline & & s & 8 & 5 & s & $\$$ & $\$$ & $\$$ \\
\hline 1837 & - & - & 7.00 & - & - & - & - & - \\
\hline 1838 & - & - & 7.00 & - & - & - & - & - \\
\hline 1839 & 一 & - & 6.50 & - & - & - & - & - \\
\hline 1840 & - & - & 6.00 & - & - & - & - & - \\
\hline 1841 & - & - & 5.50 & - & - & - & - & - \\
\hline 1842 & - & - & 5.00 & - & - & - & - & - \\
\hline 1844 & - & 89.92 & 5.00 & - & - & - & - & - \\
\hline 1845 & - & 95.75 & 6.00 & - & - & - & - & - \\
\hline 1846 & - & $91.66^{\circ}$ & 6.00 & - & - & - & - & - \\
\hline 1847 & - & 86.04 & 6.00 & - & - & - & - & - \\
\hline 1848 & - & 79.33 & 6.00 & - & - & - & - & $\ldots$ \\
\hline 1849 & - & 67.50 & 6.00 & - & - & - & - & - \\
\hline 1850 & - & 59.54 & 4.50 & - & - & - & - & - \\
\hline 1851 & - & 54.66 & 4.50 & - & - & - & - & - \\
\hline \multirow[t]{2}{*}{1852} & - & 58.79 & 1.50 & - & - & - & - & 一 \\
\hline & October & 56.00 & 4.50 & - & 一 & - & - & - \\
\hline \multirow[t]{3}{*}{1853} & March & . 100.80 & 4.50 & .70 & - & - & - & - \\
\hline & June . & . 100.80 & 4.50 & .70 & - & - & 一 & - \\
\hline & September & . 78.40 & 5.00 & .70 & - & - & 一 & 一 \\
\hline 1854 & & 78.40 & 5.00 & .70 & $\ldots$ & - & - & - \\
\hline \multirow[t]{3}{*}{1855} & February & 78.40 & 4.00 & .75 & - & - & - & - \\
\hline & March & 67.20 & 4.00 & .75 & - & - & - & - \\
\hline & May. & - & 5.50 & .75 & - & - & 一 & - \\
\hline 1856 & March & 61.60 & 4.50 & $.62 \frac{1}{2}$ & - & - & - & 一 \\
\hline 1857 & February & 95.20 & 4.50 & $.75^{5}$ & - & - & - & 一 \\
\hline \multirow[t]{2}{*}{1858} & , & 95.20 & 3.50 & $.62 \frac{1}{2}$ & 一 & - & - & - \\
\hline & Norember & - & 3.25 & $.62 \frac{1}{2}$ & 一 & - & 一 & 一 \\
\hline \multirow[t]{2}{*}{1859} & March & 95.20 & 3.75 & $.60^{\circ}$ & - & 一 & - & 一 \\
\hline & October & 61.60 & 3.75 & .60 & 一 & - & 一 & 一 \\
\hline \multirow[t]{6}{*}{1860} & February & 50.40 & 3.75 & $.62 \frac{1}{2}$ & - & - & - & - \\
\hline & May . & 95.20 & 3.75 & $.62 \frac{1}{2}$ & - & - & - & 一 \\
\hline & July . & 89.60 & 3.75 & $.62 \frac{1}{2}$ & 一 & - & - & 一 \\
\hline & August & 95.20 & 3.75 & $.62 \frac{1}{2}$ & - & - & 一 & - \\
\hline & September & 95.20 & 3.75 & $.62 \frac{1}{2}$ & 一 & 一 & - & - \\
\hline & December & - & 4.00 & $.62 \frac{1}{2}$ & - & 一 & - & - \\
\hline \multirow[t]{3}{*}{1861} & January & 50.40 & 4.00 & $.60^{2}$ & 一 & 一 & 一 & - \\
\hline & February & - & 3.75 & .60 & - & - & $\ldots$ & - \\
\hline & October & 50.40 & 3.56 & .60 & - & - & - & - \\
\hline \multirow[t]{6}{*}{1862} & April . & . 100.80 & 4.00 & .70 & - & - & - & - \\
\hline & July . & . $\quad 61.60$ & 4.50 & .70 & - & - & - & - \\
\hline & August & 67.20 & 4.50 & .70 & - & - & - & 一 \\
\hline & September & - & 5.00 & .70 & - & - & - & 一 \\
\hline & October & 72.80 & 5.00 & .70 & - & - & - & - \\
\hline & December & 89.60 & 5.00 & .70 & - & - & - & - \\
\hline \multirow[t]{2}{*}{1863} & February & 95.20 & 5.50 & .70 & 一 & - & - & - \\
\hline & April . & . $\quad-$ & - & .70 & 一 & 一 & - & 一 \\
\hline
\end{tabular}


Comparison of Scale, Sefling Rate, \&c.-continued.

\begin{tabular}{|c|c|c|c|c|c|c|c|c|c|}
\hline Year & Mouth & & $\begin{array}{c}\text { Selling } \\
\text { price } \\
\text { bar } \\
\text { iron } \\
\text { per ton }\end{array}$ & $\begin{array}{l}\text { Pud- } \\
\text { dIIins } \\
\text { rates }\end{array}$ & $\begin{array}{l}\text { Bar } \\
\text { mill } \\
\text { lueating } \\
\text { all1 } \\
\text { rolling }\end{array}$ & $\begin{array}{l}\text { Selling } \\
\text { lrice } \\
24 \mathrm{G} . \\
\text { shreet }\end{array}$ & $\begin{array}{l}\text { Rolling } \\
\text { price } \\
24 \mathrm{G} . \\
\text { sheet }\end{array}$ & $\begin{array}{c}\text { Tin } \\
\text { plate } \\
\text { box IO, } \\
\text { full } \\
\text { weight }\end{array}$ & $\begin{array}{c}\text { Rolling } \\
\text { IC, } \\
\text { full } \\
\text { weight }\end{array}$ \\
\hline \multirow{5}{*}{1863} & & & $\$$ & $a^{7}$ & & $\$$ & $\$$ & $\$$ & $\$$ \\
\hline & $\mathrm{May}^{\circ}$ & - & 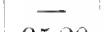 & 6.00 & .90 & 一 & 一 & 一 & - \\
\hline & August & - & 95.20 & 6.00 & .90 & - & - & $\cdots$ & 一 \\
\hline & September & - & 95.20 & 6.00 & .90 & - & - & - & - \\
\hline & Decermber & - & 123.20 & 6.58 & .90 & - & 一 & - & - \\
\hline \multirow[t]{8}{*}{1864} & January & - & 134.40 & 6.50 & .90 & - & - & 一 & - \\
\hline & February & - & 134.40 & 6.50 & .90 & 一 & - & 一 & - \\
\hline & March & - & 145.60 & 6.50 & 1.25 & 一 & - & 一 & - \\
\hline & May. & - & 156.80 & 7.00 & 1.25 & - & 一 & $\ldots$ & - \\
\hline & , & . & 156.80 & 7.50 & 1.25 & - & - & - & - \\
\hline & June & . & 156.60 & 8.00 & 1.25 & - & - & 一 & 一 \\
\hline & September & . & 156.80 & 9.00 & 1.5. & - & - & 一 & 一 \\
\hline & December & . & 168.00 & 9.00 & 1.20 & - & - & - & - \\
\hline \multirow[t]{6}{*}{1865} & January & . & - & 8.00 & 1.20 & - & - & - & - \\
\hline & March & . & $12: 30$ & 7.00 & 1.00 & - & - & 一 & - \\
\hline & April . & . & - & - & $1 \cdot 00$ & - & - & - & - \\
\hline & May . & . & - & 6.00 & - & - & - & - & - \\
\hline & August & . & 103.48 & 5.75 & - & - & - & - & - \\
\hline & September & . & 123.20 & 8.00 & 一 & - & - & 一 & - \\
\hline \multirow[t]{2}{*}{1866} & July : & . & 112.00 & 8.00 & $\dot{\vec{c}}$ & 一 & - & - & - \\
\hline & November & - & 112.00 & 9.00 & $\tilde{s}$ & - & - & - & 一 \\
\hline \multirow[t]{3}{*}{1867} & Aurgust & . & 100.80 & 8.00 & $\approx$ & 一 & - & - & - \\
\hline & October & . & 95.20 & 7.50 & 8 & 一 & - & - & - \\
\hline & , & - & 95.20 & 7.25 & 远 & 一 & - & 一 & - \\
\hline \multirow[t]{3}{*}{1868} & January & . & - & 6.75 & 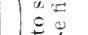 & - & - & - & - \\
\hline & February & . & 78.40 & 6.75 & 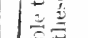 & - & - & - & - \\
\hline & March & 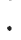 & 84.00 & 6.75 & $=$ & 一 & 一 & - & 一 \\
\hline 1869 & - & & 78.40 & 6.75 & $\tilde{E}$ & - & - & - & - \\
\hline 1870 & Inne . & . & 72.80 & 6.25 & .80 & - & - & 一 & 一 \\
\hline \multirow[t]{2}{*}{1871} & July . & . & 72.80 & 6.25 & .80 & - & - & - & 一 \\
\hline & September & . & 78.40 & 6.50 & .80 & - & - & - & - \\
\hline \multirow[t]{8}{*}{1872} & January & - & 85.12 & 6.75 & .80 & - & 一 & - & - \\
\hline & February & . & 92.96 & 7.00 & .80 & - & - & - & - \\
\hline & March & . & 100.80 & 7.50 & .80 & $\longrightarrow$ & - & - & - \\
\hline & April . & . & 107.52 & 7.75 & .80 & - & - & - & - \\
\hline & July . & - & 112.00 & 8.00 & .80 & - & - & - & - \\
\hline & August & - & 112.00 & 8.00 & .80 & - & 一 & - & - \\
\hline & September & . & 116.48 & 8.00 & .80 & 一 & - & - & - \\
\hline & December & . & 103.04 & 7.50 & .80 & 一 & - & - & - \\
\hline \multirow[t]{2}{*}{1873} & June . & . & 85.12 & 6.75 & .86 & 一 & $\ldots$ & - & - \\
\hline & October & . & 73.92 & 6.25 & .86 & 一 & 一 & 一 & 一 \\
\hline \multirow[t]{2}{*}{1874} & March & 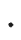 & 67.20 & 6.00 & .68 & - & - & - & - \\
\hline & December & . & 56.00 & 6.00 & .68 & 一 & 一 & - & - \\
\hline \multirow[t]{3}{*}{1875} & January & 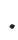 & 56.00 & 6.00 & .68 & - & 一 & - & - \\
\hline & August & 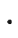 & 56.00 & 5.50 & .68 & - & - & - & - \\
\hline & November & • & 56.00 & 5.50 & .68 & - & - & - & - \\
\hline \multirow[t]{2}{*}{1876} & March & • & 56.00 & 4.75 & .70 & - & $\cdots$ & - & 一 \\
\hline & April . & $\cdot$ & 56.00 & 4.75 & .70 & - & - & - & - \\
\hline
\end{tabular}


Comparison of Scale, Seling Rate, \&c.-continued.

\begin{tabular}{|c|c|c|c|c|c|c|c|c|}
\hline Year & Month & $\begin{array}{c}\text { Selling } \\
\text { price } \\
\text { bar } \\
\text { iroul } \\
\text { per ton }\end{array}$ & $\begin{array}{l}\text { Pud- } \\
\text { dling } \\
\text { rates }\end{array}$ & $\begin{array}{c}\text { Bar } \\
\text { mill } \\
\text { heating } \\
\text { and } \\
\text { rolling }\end{array}$ & $\begin{array}{c}\text { Selling } \\
\text { price } \\
24 \mathrm{G} \\
\text { sheet }\end{array}$ & $\begin{array}{c}\text { Rolling } \\
\text { price } \\
24 \mathrm{G} . \\
\text { sheet }\end{array}$ & $\begin{array}{c}\text { Tin } \\
\text { plate } \\
\text { box IC, } \\
\text { full } \\
\text { weight }\end{array}$ & $\begin{array}{c}\text { Rolling } \\
\text { IC, } \\
\text { fuli } \\
\text { weight }\end{array}$ \\
\hline & & $\$$ & 8 & .80 & 8 & $\$$ & $\$$ & $\$$ \\
\hline $\begin{array}{l}1816 \\
1877\end{array}$ & $\begin{array}{l}\text { June } \\
\text { February }\end{array}$ & - $\quad \overline{44.80}$ & $\begin{array}{l}5.00 \\
5.00\end{array}$ & .70 & - & - & - & - \\
\hline \multirow{4}{*}{1877} & April. & $\begin{array}{l}\cdot 39.20 \\
. \quad 390\end{array}$ & 5.00 & .65 & - & - & - & - \\
\hline & , & . 44.80 & 5.00 & .65 & 一 & - & - & - \\
\hline & October & 44.80 & 5.00 & .65 & - & - & 一 & - \\
\hline & December & 44.80 & 5.00 & .65 & - & - & - & - \\
\hline \multirow[t]{2}{*}{1878} & January & 44.80 & 5.00 & .65 & - & - & - & - \\
\hline & December & 44.80 & 5.00 & .65 & - & 一 & - & - \\
\hline \multirow[t]{6}{*}{1879} & January & 39.20 & 5.00 & .65 & - & - & - & - \\
\hline & & 35.84 & 5.00 & .65 & - & 一 & - & 一 \\
\hline & July & 42.56 & 5.00 & .65 & - & - & - & - \\
\hline & August & 56.00 & 5.00 & .65 & - & - & - & 一 \\
\hline & September & 67.20 & 5.50 & .65 & - & - & - & 一 \\
\hline & Deccmber & 76.16 & 5.50 & .65 & - & - & 一 & 一 \\
\hline \multirow[t]{10}{*}{1880} & January & 78.40 & 6.00 & $.72 \frac{1}{2}$ & - & - & - & 一 \\
\hline & February & 89.60 & 7.00 & .91 & - & - & - & 一 \\
\hline & March & 89.60 & 7.00 & .91 & - & - & - & - \\
\hline & April. & 71.68 & 5.70 & .68 & - & - & - & - \\
\hline & May. & 56.00 & 5.00 & .65 & 4.30 & 8.00 & - & - \\
\hline & August & 50.40 & 5.50 & .65 & 4.30 & 8.00 & - & - \\
\hline & September & 50.40 & 5.50 & .65 & 4.30 & 8.00 & - & - \\
\hline & October & 50.40 & 5.50 & .65 & 4.30 & $\begin{array}{l}0.00 \\
8.00\end{array}$ & 一 & 一 \\
\hline & November & 50.40 & 5.50 & .65 & 4.30 & $\begin{array}{l}8.00 \\
8.00\end{array}$ & 一 & - \\
\hline & December & 50.40 & 5.50 & .65 & 4.30 & $\begin{array}{l}8.00 \\
8.00\end{array}$ & 一 & - \\
\hline \multirow[t]{19}{*}{1881} & January & 50.40 & 5.50 & .65 & 4.00 & $\begin{array}{l}8.00 \\
8.00\end{array}$ & - & - \\
\hline & & 47.04 & 5.50 & .65 & 4.00 & $\begin{array}{l}8.00 \\
8.00\end{array}$ & 一 & - \\
\hline & February & 47.04 & 5.50 & .65 & 4.00 & & - & - \\
\hline & & 57.12 & 5.50 & .65 & 3.90 & $\begin{array}{l}8.00 \\
8.00\end{array}$ & 一 & - \\
\hline & March & 47.04 & 5.50 & .65 & 3.90 & $\begin{array}{l}8.00 \\
8.00\end{array}$ & - & - \\
\hline & & 50.40 & 5.50 & .65 & 3.65 & $\begin{array}{l}8.00 \\
8.00\end{array}$ & - & 一 \\
\hline & April. & 50.40 & 5.50 & .65 & 3.75 & $\begin{array}{l}8.00 \\
8.00\end{array}$ & — & - \\
\hline &, & 48.16 & 5.50 & .65 & 3.75 & $\begin{array}{l}8.00 \\
8.00\end{array}$ & - & - \\
\hline & May. & 48.16 & 5.50 & .65 & 3.7 .5 & 8.00 & - & - \\
\hline &, & 50.40 & 5.50 & .65 & $\begin{array}{l}0.1 .3 \\
3.75\end{array}$ & 8.00 & - & - \\
\hline & June . & 50.40 & 5.50 & .70 & $\begin{array}{l}3.15 \\
3.75\end{array}$ & 8.00 & - & - \\
\hline & July . & 50.40 & 5.50 & .70 & $\begin{array}{l}3.75 \\
4.00\end{array}$ & 8.00 & - & 一 \\
\hline &,$\quad$. & 53.76 & $5 \cdot 50$ & .70 & $\begin{array}{l}4.00 \\
4.00\end{array}$ & 8.00 & - & 一 \\
\hline & August & 53.76 & 5.50 & .70 & $\begin{array}{l}4.00 \\
4.00\end{array}$ & 8.00 & 一 & - \\
\hline & , & 56.00 & 5.50 & .70 & $\begin{array}{l}4.00 \\
4.20\end{array}$ & 8.00 & - & - \\
\hline & September & 56.00 & 5.50 & .70 & & 8.00 & - & - \\
\hline & October & 56.00 & 5.50 & .70 & $\begin{array}{l}4.30 \\
4.30\end{array}$ & 8.00 & - & - \\
\hline & November & 56.00 & 5.50 & .70 & 4.30 & 8.00 & - & - \\
\hline & December & 56.00 & 5.50 & .70 & 4.30 & 8.00 & - & 一 \\
\hline \multirow[t]{4}{*}{1882} & January & 56.00 & 5.50 & $\begin{array}{r}.70 \\
70\end{array}$ & 4.30 & 8.00 & - & - \\
\hline & February & 56.00 & 5.50 & .70 & 4.30 & 8.00 & - & - \\
\hline & March & 53.76 & $\begin{array}{l}. .50 \\
5.50\end{array}$ & .70 & 4.30 & 8.00 & - & - \\
\hline & April . & 58.76 & $\begin{array}{l}5.50 \\
5.50\end{array}$ & .70 & 4.30 & 8.00 & - & - \\
\hline & & & 5.50 & .70 & 4.30 & 8.00 & - & - \\
\hline
\end{tabular}


Codiparison of Scale, Selling Rate, dc.-continued.

\begin{tabular}{|c|c|c|c|c|c|c|c|c|c|}
\hline Year & \multicolumn{2}{|l|}{ Month } & $\begin{array}{l}\text { Selling } \\
\text { price } \\
\text { bar } \\
\text { iron } \\
\text { per ton }\end{array}$ & $\begin{array}{l}\text { Pud- } \\
\text { dling } \\
\text { rates }\end{array}$ & $\begin{array}{c}\text { Bar } \\
\text { mill } \\
\text { heating } \\
\text { and } \\
\text { rolling }\end{array}$ & $\begin{array}{l}\text { Selling } \\
\text { price } \\
24 \text { G. } \\
\text { sheet }\end{array}$ & $\begin{array}{l}\text { Rolling } \\
\text { price } \\
24 \mathrm{G} \text {. } \\
\text { sheet }\end{array}$ & $\begin{array}{c}\text { Tin } \\
\text { plate } \\
\text { box IC, } \\
\text { full } \\
\text { weight }\end{array}$ & $\begin{array}{l}\text { Rolling } \\
\text { IO, } \\
\text { fuil } \\
\text { weight }\end{array}$ \\
\hline \multirow{10}{*}{1882} & & & $\$$ & $\$$ & $\$$ & 8 & $\$$ & $\$$ & $\$$ \\
\hline & May . & - & 50.40 & 5.50 & .70 & 4.30 & 8.00 & - & 一 \\
\hline & June. & . & 56.00 & 5.50 & .70 & $\begin{array}{l}4.30 \\
4.30\end{array}$ & 8.00 & 一 & - \\
\hline & July. & - & 56.00 & 0.50 & .70 & $\begin{array}{l}4.30 \\
4.30\end{array}$ & 8.00 & - & 一 \\
\hline & August & $\cdot$ & $\begin{array}{l}56.00 \\
56.00\end{array}$ & $\begin{array}{l}5.50 \\
5.50\end{array}$ & $\begin{array}{l}.70 \\
.70\end{array}$ & $\begin{array}{l}4.00 \\
4.30\end{array}$ & $\begin{array}{l}0.00 \\
8.00\end{array}$ & - & - \\
\hline & October & . & 53.76 & 5.50 & .70 & 4.30 & 8.00 & - & - \\
\hline & November & . & 51.52 & 5.50 & .70 & 4.30 & 8.00 & - & - \\
\hline & December & 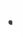 & 50.40 & 5.50 & .70 & 4.30 & 8.00 & - & - \\
\hline & , & - & 48.16 & 5.50 & .70 & 4.30 & 8.00 & 一 & 一 \\
\hline & January & . & $\begin{array}{c}\text { Per } \\
100 \text { lbs. } \\
2.25\end{array}$ & 5.50 & .70 & 4.03 & 8.00 & - & - \\
\hline & February & & 2.20 & 5.50 & .70 & 4.03 & 8.00 & - & - \\
\hline & March & . & 2.15 & 5.50 & .70 & 4.03 & 8.00 & 一 & 一 \\
\hline & April . & & $2 \cdot 10$ & 5.50 & .70 & 3.70 & 8.00 & - & 一 \\
\hline & May . & • & 2.00 & 5.50 & .70 & 3.70 & 8.00 & 一 & 一 \\
\hline & June . & - & 1.94 & 5.50 & .70 & 8.60 & 8.00 & - & 一 \\
\hline & July . & • & 1.90 & 5.50 & .70 & 3.60 & 8.00 & - & 一 \\
\hline & August. & - & 1.90 & 5.50 & .70 & 3.60 & 8.00 & 一 & 一 \\
\hline & September & . & 1.88 & 5.50 & .70 & 3.40 & 8.00 & 一 & - \\
\hline & October & $\bullet$ & 1.90 & 5.50 & .70 & 3.40 & 8.00 & - & 一 \\
\hline & November & . & 1.85 & 5.50 & .70 & 3.40 & 8.00 & 一 & 一 \\
\hline & December & - & 1.85 & 5.50 & .70 & 3.80 & 8.00 & - & 一 \\
\hline 1884 & January & • & 1.85 & 5.50 & .70 & 3.80 & 8.00 & 一 & 一 \\
\hline & February & - & 1.85 & 5.50 & .70 & 3.30 & 8.00 & 一 & 一 \\
\hline & March & - & 1.85 & 5.50 & .70 & 3.30 & 8.00 & 一 & 一 \\
\hline & April . & • & 1.85 & 5.50 & .70 & 3.25 & 800 & - & 一 \\
\hline & May . & - & 1.85 & 5.50 & .70 & 3.25 & 8.00 & - & 一 \\
\hline & June . & • & 1.80 & 5.50 & .70 & 3.06 & 8.00 & - & - \\
\hline & July . & - & 1.80 & 5.50 & .70 & 3.00 & 8.00 & - & - \\
\hline & August & . & 1.75 & 5.50 & .70 & 2.90 & 8.00 & - & 一 \\
\hline & September & • & 1.65 & 5.50 & .70 & 2.90 & 8.00 & - & - \\
\hline & October & . & 1.65 & 5.50 & .70 & 2.85 & 8.00 & - & 一 \\
\hline & November & - & 1.65 & 5.50 & .70 & 2.85 & 8.00 & - & 一 \\
\hline & December & - & 1.65 & 5.50 & .70 & 2.85 & 8.00 & - & - \\
\hline 1885 & January & • & 1.65 & 5.50 & .70 & 2.85 & 8.00 & - & - \\
\hline & February & • & 1.65 & 5.50 & .70 & 2.85 & 8.00 & - & 一 \\
\hline & March & & 1.65 & 5.50 & .70 & 2.85 & 8.00 & - & 一 \\
\hline & April . & & 1.65 & 5.50 & .70 & 2.85 & 8.00 & - & - \\
\hline & May. & - & 1.65 & 5.50 & .70 & 2.85 & 8.00 & - & - \\
\hline & June . & • & 1.65 & 5.00 & .63 & 2.85 & 8.00 & 一 & 一 \\
\hline & July . & - & 1.65 & 5.00 & .63 & 2.85 & 8.00 & - & 一 \\
\hline & August & . & 1.65 & 5.00 & .63 & 2.85 & 8.00 & - & - \\
\hline & September & . & 1.65 & 5.00 & .63 & 2.90 & 8.00 & - & 一 \\
\hline & October & • & 1.65 & 5.00 & .63 & 2.90 & 8.00 & - & - \\
\hline & November & - & 1.65 & 5.00 & .63 & 2.90 & 8.00 & - & 一 \\
\hline & December & 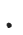 & 1.65 & 5.00 & .63 & 2.90 & 8.00 & -- & - \\
\hline
\end{tabular}


Compatison of Scale, Selling Rate, de.-continued.

\begin{tabular}{|c|c|c|c|c|c|c|c|c|c|}
\hline Year & Month & & $\begin{array}{c}\text { Selling } \\
\text { price } \\
\text { bar } \\
\text { iron } \\
\text { per } \\
\text { 1uv lbs. }\end{array}$ & $\begin{array}{l}\text { Pui- } \\
\text { dling } \\
\text { rates }\end{array}$ & $\begin{array}{c}\text { Bar } \\
\text { mill } \\
\text { heating } \\
\text { and } \\
\text { rolling }\end{array}$ & $\begin{array}{l}\text { Selling } \\
\text { price } \\
246 . \\
\text { sheet }\end{array}$ & $\begin{array}{l}\text { Rolling } \\
\text { price } \\
34 \mathrm{ft} \\
\text { sheet }\end{array}$ & $\begin{array}{c}\text { Tin } \\
\text { plate } \\
\text { box IO, } \\
\text { full } \\
\text { weight }\end{array}$ & $\begin{array}{c}\text { Rolling } \\
\text { IC, } \\
\text { full } \\
\text { weight }\end{array}$ \\
\hline \multirow{12}{*}{1886} & Jannary & & 1.70 & 5.00 & $\stackrel{\$}{63}$ & 2.90 & 8.00 & $\$$ & $\$$ \\
\hline & February & & 1.70 & 5.00 & .63 & 2.90 & 8.00 & - & - \\
\hline & March & . & 1.70 & 5.00 & .63 & 2.90 & 8.00 & _- & - \\
\hline & April . & . & 1.70 & 5.00 & .63 & 2.90 & 8.00 & 一 & - \\
\hline & May. & & 1.70 & 5.00 & .63 & 2.90 & 8.00 & - & - \\
\hline & June . & . & 1.70 & 5.00 & .63 & 2.90 & 8.00 & - & - \\
\hline & July . & • & 1.70 & 5.00 & .63 & 2.85 & 8.00 & - & - \\
\hline & August & . & 1.70 & 5.00 & .63 & 2.85 & 8.00 & - & - \\
\hline & September & . & 1.70 & 5.00 & .63 & 2.85 & 8.00 & - & - \\
\hline & October & . & 1.75 & 5.00 & .63 & 2.85 & 8.00 & - & - \\
\hline & November & . & 1.80 & 5.00 & .63 & 2.85 & 8.00 & - & - \\
\hline & December & . & 1.85 & 5.00 & .63 & 2.95 & 8.00 & - & - \\
\hline \multirow{12}{*}{1887} & January & . & 2.00 & 5.00 & .63 & 3.00 & 8.00 & - & - \\
\hline & February & . & 2.00 & 5.00 & .63 & 3.00 & 8.00 & 一 & - \\
\hline & March & . & 2.00 & 5.00 & .63 & 3.00 & 8.00 & - & — \\
\hline & April. & & 2.00 & 5.00 & .63 & 3.00 & 8.00 & - & $\ldots$ \\
\hline & May. & & 2.00 & 5.00 & .63 & 3.00 & 8.00 & - & - \\
\hline & Jnne . & . & 2.00 & 5.50 & .70 & 2.80 & 8.00 & - & - \\
\hline & July & ${ }^{\circ}$ & 2.00 & 5.50 & .70 & 2.90 & 8.00 & 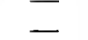 & - \\
\hline & Angust & . & 1.90 & 5.50 & .70 & 2.90 & 8.00 & 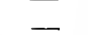 & - \\
\hline & September & • & 1.90 & 5.50 & .70 & 2.90 & 8.00 & - & - \\
\hline & October & 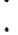 & 1.90 & 5.50 & .70 & 2.90 & 8.00 & - & - \\
\hline & Novenber & . & 1.90 & 5.50 & .70 & 2.90 & 8.00 & - & - \\
\hline & December & . & 1.90 & 5.50 & .70 & 2.90 & 8.00 & - & - \\
\hline \multirow[t]{12}{*}{1888} & January & . & 1.90 & 5.50 & .70 & 2.90 & 8.00 & - & - \\
\hline & February & . & 1.85 & 5.50 & .70 & 2.90 & 8.00 & 一 & $\ldots$ \\
\hline & March & & 1.80 & 5.50 & .70 & 2.80 & 8.00 & $\ldots$ & - \\
\hline & April . & & 1.80 & 5.50 & .70 & 2.75 & 8.00 & $\ldots$ & - \\
\hline & May. & . & 1.80 & 5.50 & .70 & 2.75 & 8.00 & - & - \\
\hline & June. & & 1.75 & 5.50 & .70 & 2.70 & 8.00 & - & - \\
\hline & July . & . & 1.75 & 5.50 & .70 & 2.70 & 8.00 & - & — \\
\hline & Angust & . & 1.5 & 5.50 & .70 & 2.70 & 8.00 & 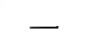 & -_ \\
\hline & September & . & 1.80 & 5.50 & .70 & 2.80 & 8.00 & 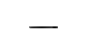 & - \\
\hline & October & . & 1.80 & 5.50 & .70 & 2.85 & 8.00 & 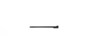 & 一 \\
\hline & November & . & 1.80 & 5.50 & .70 & 2.85 & 8.00 & 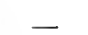 & - \\
\hline & December & 。 & 1.80 & 5.50 & .70 & 2.85 & 8.00 & - & - \\
\hline \multirow[t]{11}{*}{1889} & January & • & 1.80 & 5.50 & .70 & 2.85 & 8.00 & - & - \\
\hline & February & & 1.75 & 5.50 & .70 & 2.80 & 8.00 & - & - \\
\hline & Mareh & & 1.75 & 5.50 & .70 & 2.50 & 8.00 & - & 一 \\
\hline & April . & & 1.70 & 5.50 & .70 & 2.70 & 8.00 & - & - \\
\hline & May . & & 1.70 & 5.50 & .70 & 2.70 & 8.00 & - & - \\
\hline & June. & & 1.70 & 5.50 & .70 & 2.70 & 8.00 & - & - \\
\hline & July : & & 1.70 & 5.50 & .70 & 2.70 & 8.00 & - & - \\
\hline & August & & 1.75 & 5.50 & .70 & 2.70 & 8.00 & - & - \\
\hline & September & & 1.80 & 5.50 & .70 & 2.85 & 8.00 & $\ldots$ & — \\
\hline & October & & 1.80 & 5.50 & .70 & 2.90 & 8.100 & - & - \\
\hline & November & . & 1.85 & 5.50 & .70 & 2.95 & 8.00 & - & — \\
\hline
\end{tabular}


Comparison of Scale, Seluing Rate, \&c.-continued.

\begin{tabular}{|c|c|c|c|c|c|c|c|c|}
\hline Year & Montli & $\begin{array}{c}\text { Selling } \\
\text { price } \\
\text { bar } \\
\text { iron } \\
\text { fer } \\
\text { 100 lbs. }\end{array}$ & $\begin{array}{l}\text { Pul- } \\
\text { dling } \\
\text { rates }\end{array}$ & $\begin{array}{c}\text { Bar } \\
\text { mill } \\
\text { leating } \\
\text { andi } \\
\text { rollurg }\end{array}$ & $\begin{array}{l}\text { Selling } \\
\text { price } \\
21 \mathrm{r} \text {. } \\
\text { sheet }\end{array}$ & $\begin{array}{l}\text { Rolling } \\
\text { mrire } \\
24 \mathrm{G} \\
\text { slitet }\end{array}$ & $\begin{array}{c}\text { Tin } \\
\text { plate } \\
\text { box IC, } \\
\text { full } \\
\text { weight }\end{array}$ & $\begin{array}{c}\text { Rolling } \\
\text { IC, } \\
\text { full } \\
\text { weight }\end{array}$ \\
\hline 1889 & December & 1.90 & 5.50 & .70 & $\begin{array}{l}\dot{x} \\
3.00\end{array}$ & 8.00 & 8 & 8 \\
\hline \multirow{12}{*}{1890} & Tannary & 1.90 & 5.50 & .70 & $\because 3.10$ & 8.00 & 4.79 & 5.30 \\
\hline & February & 1.90 & 5.50 & .70 & 3.00 & 8.00 & 4.61 & 5.30 \\
\hline & Narch & 1.85 & 5.50 & .70 & 2.90 & $\$ .00$ & 4.46 & 5.30 \\
\hline & April . & 1.85 & 5.50 & .70 & 2.90 & 8.00 & 4.39 & 5.30 \\
\hline & May. & 1.80 & 5.50 & .70 & 2.85 & 8.00 & 4.35 & 5.30 \\
\hline & Tnine. & 1.85 & 5.50 & .70 & 2.85 & 8.00 & 4.39 & 5.30 \\
\hline & July & 1.85 & 5.50 & .70 & 2.85 & 8.00 & 4.45 & 5.30 \\
\hline & August & 1.85 & 5.50 & .70 & 2.55 & 8.00 & 4.65 & 5.30 \\
\hline & September & 1.85 & 5.50 & .70 & 2.85 & 8.00 & $5.17 \frac{1}{3}$ & 5.30 \\
\hline & Octuber & 1.85 & 5.50 & .70 & 2.85 & 8.00 & $5.41^{2}$ & 5.30 \\
\hline & November & 1.85 & 5.50 & .70 & 2.85 & 8.00 & 5.41 & 5.30 \\
\hline & Decentber & 1.85 & 5.50 & .70 & 2.85 & 8.00 & 5.25 & 5.30 \\
\hline \multirow{12}{*}{1891} & January & 1.80 & 5.50 & .70 & 2.80 & 8.00 & 5.34 & 5.30 \\
\hline & Felumary & 1.80 & 5.50 & .70 & 2.80 & 8.00 & 5.41 & 5.30 \\
\hline & March & 1.75 & 5.50 & .70 & 2.80 & 8.00 & 5.35 & 5.30 \\
\hline & April. & 1.70 & 5.50 & .70 & 2.80 & 8.00 & 5.23 & 5.30 \\
\hline & May. & 1.70 & 5.50 & .70 & 2.80 & 8.00 & 5.10 & 5.30 \\
\hline & Jume. & 1.70 & 5.50 & .70 & 2.80 & 8.00 & 5.30 & 5.30 \\
\hline & Tilly & 1.70 & 5.50 & .70 & 2.80 & 8.00 & 5.28 & 5.30 \\
\hline & Angust & 1.65 & 5.50 & .70 & 2.75 & 8.00 & 5.35 & 5.30 \\
\hline & September & 1.65 & 5.50 & .70 & 2.75 & 8.00 & $5.37 \frac{1}{2}$ & 5.30 \\
\hline & October & 1.6 .5 & 5.50 & .70 & 2.75 & 8.00 & $5.32^{2}$ & 5.30 \\
\hline & November & 1.65 & 5.50 & .70 & 2.75 & 8.00 & 5.25 & 5.30 \\
\hline & December & 1.65 & 5.50 & .70 & 2.60 & 8.00 & 5.25 & 5.30 \\
\hline \multirow[t]{12}{*}{1892} & Jannary & 1.65 & 5.50 & .70 & 2.60 & 8.00 & 5.25 & 5.30 \\
\hline & February & 1.65 & 5.50 & .70 & 2.60 & 8.00 & 5.25 & 5.30 \\
\hline & March & 1.60 & 5.50 & .70 & 2.55 & 8.00 & 5.25 & 5.30 \\
\hline & April . & 1.60 & 5.50 & .70 & 2.55 & 8.00 & 5.25 & 5.30 \\
\hline & May. & 1.60 & 5.50 & .70 & 2.55 & 8.00 & 5.25 & 5.30 \\
\hline & June & 1.60 & 5.50 & .70 & 2.55 & 8.00 & 5.25 & 5.30 \\
\hline & July & 1.60 & 5.50 & .70 & 2.55 & 8.00 & 5.25 & 5.30 \\
\hline & Angust & 1.60 & 5.50 & .63 & 2.55 & 8.00 & 5.20 & 5.30 \\
\hline & September & 1.60 & 5.50 & .63 & 2.55 & 8.00 & 5.18 & 5.30 \\
\hline & October & 1.60 & 5.50 & .63 & 2.70 & 8.00 & 5.20 & 5.30 \\
\hline & November & 1.60 & 5.50 & .63 & 2.70 & 8.00 & 5.45 & 5.30 \\
\hline & December & 1.60 & 5.50 & .63 & 2.75 & 8.00 & 5.50 & 5.30 \\
\hline \multirow[t]{10}{*}{1893} & Jannary & 1.60 & 5.50 & .63 & 2.70 & 8.00 & 5.35 & 5.30 \\
\hline & February & 1.60 & 5.50 & .63 & 2.70 & 8.00 & 5.35 & 5.30 \\
\hline & March & 1.60 & 5.50 & .63 & 2.70 & 8.00 & 5.35 & 5.80 \\
\hline & April . & 1.60 & 5.50 & .63 & 2.70 & 8.00 & 5.50 & 5.30 \\
\hline & May. & 1.55 & 5.50 & .63 & 2.65 & 8.00 & 5.50 & 5.30 \\
\hline & June. & 1.55 & 5.50 & .63 & 2.65 & 8.00 & 5.42 & 5.30 \\
\hline & July . & 1.55 & 5.00 & .63 & 2.65 & 8.00 & 5.30 & 5.30 \\
\hline & Ausust & 1.55 & 5.00 & .63 & 2.65 & 8.00 & 5.25 & 5.30 \\
\hline & September & 1.50 & 5.00 & .56 & 2.60 & 8.00 & 5.20 & 5.30 \\
\hline & October & 1.50 & 5.00 & .56 & 2.60 & 8.00 & $5.27 \frac{1}{2}$ & 5.30 \\
\hline
\end{tabular}


Comparison of Scale, Selling Rate, \&c.-continued.

\begin{tabular}{|c|c|c|c|c|c|c|c|c|c|}
\hline Year & Month & & $\begin{array}{c}\text { Selling } \\
\text { yrice } \\
\text { bar } \\
\text { iron } \\
\text { per } \\
100 \mathrm{lbs} .\end{array}$ & $\begin{array}{l}\text { Pud- } \\
\text { dling } \\
\text { rates }\end{array}$ & $\begin{array}{l}\text { Bar } \\
\text { mill } \\
\text { heating } \\
\text { and } \\
\text { rolling }\end{array}$ & $\begin{array}{l}\text { Selling } \\
\text { price } \\
24 \mathrm{G} \text {. } \\
\text { sheet }\end{array}$ & $\begin{array}{l}\text { Rolling } \\
\text { price } \\
24 G \text {. } \\
\text { sheet }\end{array}$ & $\begin{array}{c}\text { Tin } \\
\text { plate } \\
\text { box IO, } \\
\text { full } \\
\text { weight }\end{array}$ & $\begin{array}{c}\text { Rolling } \\
\text { IO, } \\
\text { full } \\
\text { weight }\end{array}$ \\
\hline \multirow{14}{*}{1894} & November & . & $\$$ & 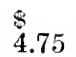 & .56 & $\stackrel{\$}{2.57}$ & $\$$ & $\begin{array}{c}\$ \\
5.32\end{array}$ & $\begin{array}{l}\$ \\
5.30\end{array}$ \\
\hline & December & . & 1.47 & 4.75 & .56 & 2.52 & 7.20 & 5.30 & 5.30 \\
\hline & January & . & 1.32 & 4.75 & .56 & 2.37 & 7.20 & 5.26 & 5.30 \\
\hline & February & & 1.25 & 4.75 & .56 & 2.30 & 7.20 & 5.26 & 5.30 \\
\hline & March & . & 1.25 & 4.75 & .56 & 2.30 & 7.20 & 5.20 & 5.30 \\
\hline & April & . & 1.25 & 4.00 & .56 & 2.30 & 7.20 & 5.18 & 5.30 \\
\hline & May & . & 1.17 & 4.00 & .56 & 2.30 & 7.20 & 5.15 & 5.30 \\
\hline & June . & & 1.10 & 4.00 & .56 & 2.30 & 7.20 & 5.14 & 5.30 \\
\hline & July . & & 1.10 & 4.00 & .56 & 2.30 & 7.20 & $5.12 \frac{1}{2}$ & 5.30 \\
\hline & August & . & 1.10 & 4.00 & .56 & 2.30 & 7.20 & $5.12^{2}$ & 5.30 \\
\hline & September & . & 1.07 & 4.00 & .56 & 2.30 & 7.20 & $4.71 \frac{1}{2}$ & 5.30 \\
\hline & October & . & 1.01 & 4.00 & .56 & 2.26 & 7.20 & $4.09 \frac{1}{4}$ & 5.30 \\
\hline & November & . & .96 & 4.00 & .56 & 2.25 & 7.20 & $4.10^{x}$ & 5.30 \\
\hline & December & . & .95 & 4.00 & .56 & 2.25 & 7.20 & 4.00 & 5.30 \\
\hline \multirow[t]{12}{*}{1895} & January & . & 1.00 & 4.00 & .56 & 2.25 & 7.20 & 3.96 & 4.50 \\
\hline & February & • & 1.00 & 4.00 & .56 & 2.25 & 7.20 & $3.87 \frac{1}{2}$ & 4.50 \\
\hline & March & 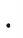 & 1.00 & 4.00 & .56 & 2.25 & 7.20 & $3.80^{\circ}$ & 4.50 \\
\hline & April . & . & 1.00 & 4.00 & .56 & 2.15 & 7.20 & 3.80 & 4.50 \\
\hline & May. & . & 1.05 & 4.00 & .56 & 2.07 & 7.20 & 3.80 & 4.50 \\
\hline & June. & . & $1.16 \frac{1}{4}$ & 4.00 & .56 & 2.17 & 7.20 & 3.80 & 4.50 \\
\hline & July . & . & $1.16_{4}^{7}$ & 4.00 & .56 & 2.27 & 7.20 & $3.82 \frac{1}{2}$ & 4.50 \\
\hline & August & . & $1.22^{*}$ & 4.25 & .56 & 2.42 & 7.20 & $3.90^{-}$ & 4.50 \\
\hline & September & . & $1.3 \% 3.3$ & 4.25 & $.59 \frac{9}{10}$ & 2.50 & 7.20 & 3.95 & 4.50 \\
\hline & October & . & $1.35^{1}$ & 4.25 & $.59 \frac{0}{10}$ & 2.50 & 7.20 & 4.00 & 4.50 \\
\hline & November & . & 1.35 & 4.25 & $.59^{9} \frac{9}{10}$ & 2.45 & 7.34 & $3.92 \frac{1}{2}$ & 4.50 \\
\hline & December & . & $1.31 \frac{1}{4}$ & 4.25 & $.59 \frac{9}{10}$ & 2.45 & 7.34 & $3.80^{\circ}$ & 4.50 \\
\hline \multirow[t]{12}{*}{1896} & January & . & 1.15 & 4.25 & $.59 \frac{1}{10}$ & 2.37 & 7.20 & 4.00 & 4.50 \\
\hline & February & & 1.15 & 4.25 & $.59_{10}^{\frac{1}{1}}$ & 2.23 & 7.20 & 3.93 & 4.50 \\
\hline & March & 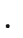 & 1.10 & 4.00 & $.56_{\frac{7}{10}}^{7}$ & 2.13 & 7.20 & 3.80 & 4.50 \\
\hline & April & 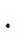 & 1.10 & 4.00 & $.56 \frac{7}{10}$ & 2.06 & 7.20 & 3.70 & 4.50 \\
\hline & May & & 1.10 & 4.00 & $.56_{\frac{7}{10}}^{7}$ & 2.10 & 7.20 & 3.55 & 4.50 \\
\hline & June . & $\cdot$ & 1.10 & 4.00 & $.56 \frac{7}{10}$ & 2.15 & 7.20 & 3.55 & 4.50 \\
\hline & July & $\cdot$ & 1.10 & 4.50 & $.56_{10}^{70}$ & 2.10 & 7.20 & 3.56 & 4.50 \\
\hline & August & & 1.10 & 4.50 & $.56 \frac{7}{10}$ & 2.10 & 7.20 & 3.60 & 4.50 \\
\hline & September & . & 1.10 & 4.50 & $.56 \frac{7}{10}$ & 2.10 & 7.20 & 3.58 & 4.50 \\
\hline & October & & 1.10 & 4.50 & $.56_{10}^{7}$ & 2.10 & 7.20 & 3.56 & 4.50 \\
\hline & November & • & 1.10 & 4.50 & $.56 \frac{70}{10}$ & 2.10 & 7.20 & 3.63 & 4.50 \\
\hline & December & & 1.15 & 4.50 & $.56_{\frac{7}{10}}^{10}$ & 2.10 & 7.20 & 3.55 & 4.50 \\
\hline \multirow[t]{6}{*}{1897} & January & . & 1.13 & 4.50 & $.56 \frac{7}{10}$ & 2.07 & 7.20 & 3.55 & 4.50 \\
\hline & February & & 1.10 & 4.50 & $.56 \frac{7}{10}$ & 2.05 & 7.20 & 3.23 & 4.50 \\
\hline & March & 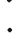 & 1.10 & 4.50 & $.56_{\frac{10}{1} \sigma}^{7}$ & 1.95 & 7.20 & $3.17 \frac{1}{2}$ & 4.50 \\
\hline & April . & $\bullet$ & 1.01 & 4.50 & .5670 & 1.85 & 7.20 & $3.33^{2}$ & 4.50 \\
\hline & May . & & $.93 \frac{1}{2}$ & 4.50 & $.56 \frac{7}{10}$ & 1.80 & 7.20 & 3.34 & 4.50 \\
\hline & June . & & $.90^{-}$ & 4.50 & $.56_{\overline{1}}^{7}$ & 1.75 & 7.20 & 3.55 & 4.50 \\
\hline
\end{tabular}

The first general guide, hoop and cotton-tie mill scale for 
the Pittsburg district, was made April 2, 1872, and the base price was $\$ 4$ per ton on a $4 \frac{1}{2}$-cent card-rate, with a minimum card-rate of $2 \frac{1}{4}$ cents. The rates were for working billets, and 50 cents per ton extra for working piles. This made a complication in understanding the card, as the price of iron was usually below the $4 \frac{1}{2}$ rate, and a percentage taken from the card was necessary to determine the rate; for instance, $2 \frac{1}{2}$ card-rate was 40 per cent. less than the $\$ 4$ base. The scale was placed on the regular bar-iron card in June, 1886.

First scales were made for the following departments in Pittsburg :-

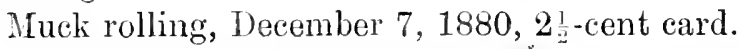

Bar and nail plate, rolling and heating, October 17, 1879, 2 -cent card.

Sheet and jobbing mill, rolling, \&c., March 1, 1880, based on $3 \frac{1}{2}$-cent card, minimum of $2 \frac{1}{2}$-cent card.

Sheet mill, roughing and catching, May 15, 1880, same card as sheet rolling.

Scrapping and busheling and heating in a scrap furnace,

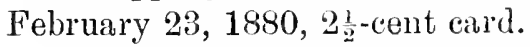

Knobbling, February 23, 1880, $2 \frac{1}{2}$-cent card.

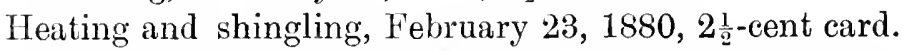

Tin and black plate mills, March 15, 1880, $2 \frac{1}{2}$-cent card.

Puddling scale in 1866.

The above data have been secured only after a great deal of research, and will pirobably never again be produced in this concise form for so many past years, unless taken from this list. It would, therefore, be well for all interested in the history of these rates to lay this away in a safe place for reference.

(Printed in the Report of the Industrial Commission, vol. vii. 1901.) 
2. Agreements for 1900-1901 between the Manufacturers and the Amalgaisated Association of Iron, Steel, and Tin Workers.

As set forth in the Report of the Industrial Commission, $\mathrm{x}$ vii. 342 .

The agreement of 1900-1901 provided that when the price of bar iron should be 1.4 cents per pound, the rate for boiling a ton of 2,240 pounds should be $\$ 5.00$. The changes in rates as prices fall or advance are shown in the following table:-

\section{Boiling.}

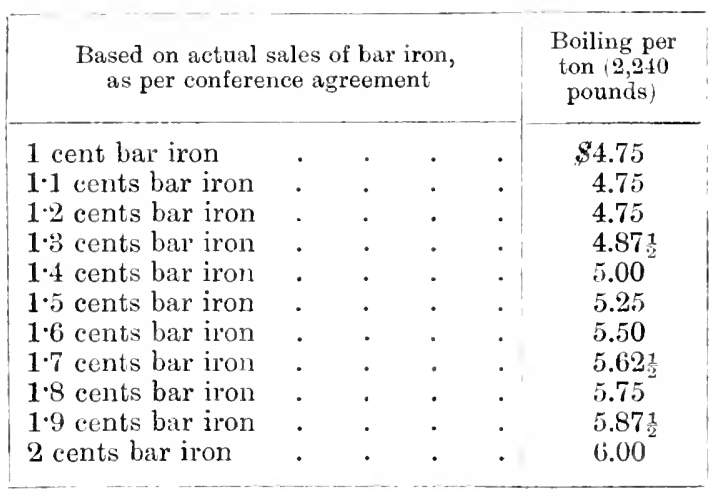

It will be observed that the rate of increase in wages is less rapid when prices are above 1.7 cents than when they are below that rate. It will also be observed that there is no provision for lowering wages if prices fall below $1 \cdot 2$ cents.

In several of the scales fixing the rates for other classes of work there is a minimum below which wages shall not fall. Thus, in the case of the agreement regarding wages in tinplate mills, the basing rates are fixed on the price of $\$ 4$ per box of 100 pounds of coke tinplates. As prices rise 10 cents per box ( $2 \frac{1}{2}$ per cent.) wages increase 2 per cent., but it is stated in the agreement that the wage fixed on the basis of $\$ 4$ per box is the minimum for the year. 
In the case of several classes of iron and steel manufacture, the wage scales become highly elaborate. Not only are the rates for three or four different classes of workmen prescribed, but there are many different sizes and linds of articles manufactured for each of which the rates are fixed. All of these rates then rise and fall in proportion to prices. As an illustration of the complexity of these scales, a part of the table for guide, 10-inch, hoop, and cotton-tie mills is inserted below (scale of 1900-1901) :-

Guide, 10-Inch, Hoop, and Cotton-Tie Mills.

It is agreel that the base price at a one and four-tenths $\left(1_{1 \%}^{\left.\frac{4}{1}\right)}\right.$ cent card-rate based on actual sales of bar iron, as per conference agreement, with extras, shall be the straight one dollar and twenty-five cents $(\$ 1.25)$ per ton for rolling, sixty-

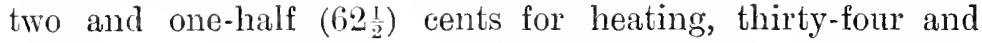
three-fourths (34) cents for roughing, and thirty-four and

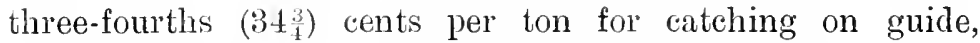
10-inch, hoop, and cotton-tie mills, with two (2) per cent. additional for each one-tenth $\left(\frac{1}{11}\right)$ advance or decline on said card from one and four-tenths $\left(1_{10}^{\left.\frac{4}{1}\right)}\right.$ to tro (2) cent card.

The rollers, heaters, roughers, and catchers shall each be paid by the company. It is understood, however, that this arrangement shall in no way detract from the authority of the roller in controlling all hands on mill, including hiring and discharging, and, as heretofore, the roller shall be held responsible for the work done.

The following figures to be advanced ten (10) per cent.

\begin{tabular}{|c|c|c|c|c|c|}
\hline & Sizes & Total & Roller & Heater & $\begin{array}{l}\text { Rougher } \\
\text { and } \\
\text { catcher, } \\
\text { each }\end{array}$ \\
\hline 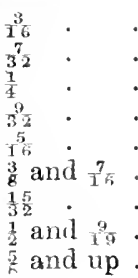 & Rounds and squares & $\begin{array}{l}\$ 8.35 \\
6.71 \\
5.19 \\
4.52 \\
3.87 \\
3.08 \\
2.95 \\
2.81 \\
2.55\end{array}$ & $\begin{array}{l}\$ 4.08 \\
3.28 \\
2.54 \\
2.21 \\
1.89 \\
1.51 \\
1.44 \\
1.38 \\
1.25\end{array}$ & \begin{tabular}{|l}
$\$ 2.04$ \\
1.64 \\
1.27 \\
$1.10 \frac{1}{2}$ \\
$.94 \frac{1}{2}$ \\
$.75 \frac{1}{2}$ \\
.72 \\
.69 \\
$.62 \frac{1}{2}$
\end{tabular} & \begin{tabular}{|}
$\$ 1.11 \frac{1}{2}$ \\
$.89 \frac{1}{2}$ \\
.69 \\
$.60 \frac{1}{4}$ \\
$.51 \frac{3}{4}$ \\
$.40 \frac{3}{4}$ \\
$.38 \frac{1}{2}$ \\
.37 \\
$.33 \frac{3}{4}$
\end{tabular} \\
\hline
\end{tabular}




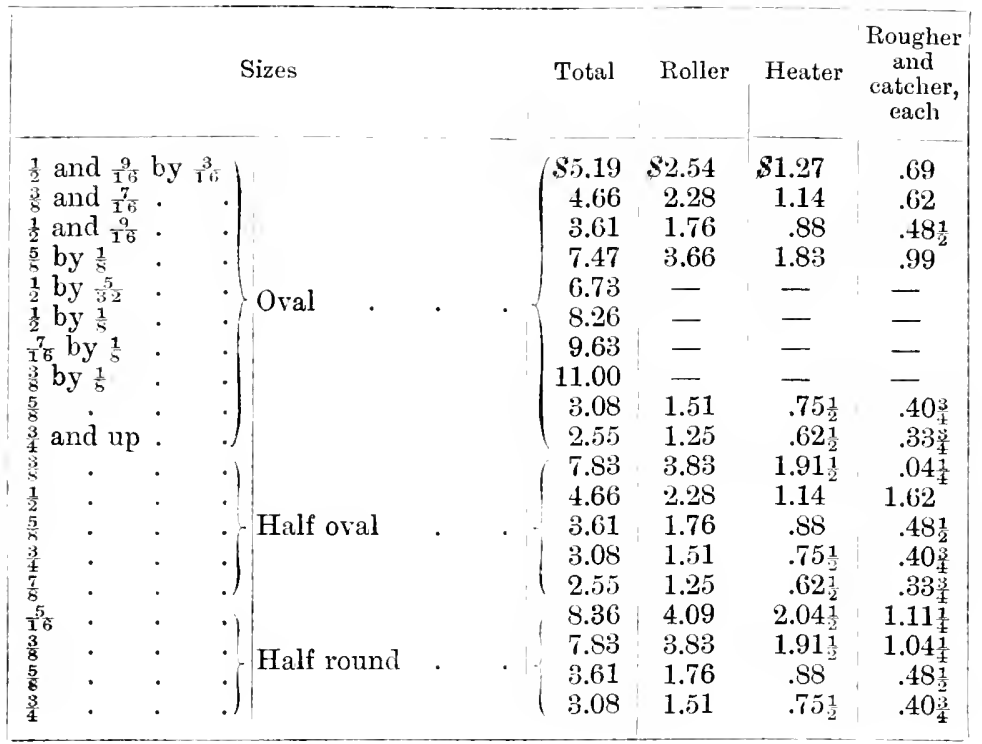

The rates of progression in wages as compared with the progression in prices differ considerably on different classes of articles, depending, of course, largely on the proportion which the labour cost of the articles bears to the entire cost. The more common provision seems to be that wages shall advance by 2 per cent. steps for increases of from 3 to 5 per cent. in prices. Of course an advance in prices may be accompanied by so great an advance in the cost of raw materials that the worling men gain more than the employer by a rise in prices, while in other cases the employer may get more advantage than the working men.

In the case of steel-rail mills and various other classes of mills not covered by the uniform scale, the local agreements establish sliding scales based either upon the general scales above described, with allowances for local conditions and peculiarities, or based upon the prices of steel rails and other articles as published in some standard trade journal. The methods are very similar to those already outlined.

It is customary in mills where the sliding-scale system 
prevails to make changes of wages once in two months on the basis of prices during the preceding two months.

3. Account of the Sratey of Adjugting Scale of Wages, \&c., in certain Polding Milds. By James H. Nutt, Adjuster.

Having been employed in Juine, 1892, and continuously since, by certain mills manufacturing bar-iron and steel as an adjuster of wage scales and other differences that have arisen between the manufacturers and the employees, it seems probable that an account of the system under which my duties have been performed and my experiences, together with some expression of opinion as to the results and benefits of such system, would be of interest to those whose attention has been directed toward the conditions of the labour interests of the country.

The concerns for which I have worked were all independent until recently, when they formed what is known as the 'Labour Burean Association.' The mills contained therein are all situated west of Pittsburg, Pa., and include nearly all the bar-iron manufacturers doing lusiness west and south of Pittsburg. These mills all negotiate with the Amalgamated Association of Iron, Steel, and Tin Workers.

The method by which differences between the parties are settled and adjusted may be described as follows: In June of each year the manufacturers meet in conference with a committee representing the workmen and make an agreement for the year beginning on the first day of July following, concerning the scale of wages, \&c. The duties of the adjuster require him to be present and assist in the making of the scale of wages, which is based upon the sales and shipments of base sizes of bar-iron. The price per pound received for material shipped during May and June will fix the price per ton that the workmen will receive for their labour during July and August, and so on for every two months during the year.

At the end of each bi-monthly period the manufacturers make sworn statements to the adjuster, and, together with a 
committee of three, one of whom must be an officer of the National Lodge of the Amalgamated Association of Iron, Steel, and Tin Workers, he goes over these sworn statements, and, according to what the price at which the material was sold is found to be, it is decided whether or not there shall be an advance or reduction in the wages of the workmen.

Under the agreement made in the annual June conference, if for any reason the committee of three are not satisfied with the sworn reports, they have the right to examine the books and accounts from which these reports are made. In case of any disagreement in any of the mills as to the construction of the agreement made in the annual June conference, the matter is referred to the adjuster by the manufacturers, and it then becomes his duty to visit the works and endeavour to make a settlement with the parties interested. If a failure results from this attempt at adjustment, the proper officer or officers of the amalgamated association are brought in, and the question is taken up and discussed from a national standpoint, and, as a rule, a satisfactory adjustment is arrived at.

In addition to the question of the wage scale, the enforcement of rules and cases where workmen are discharged form the major part of the differences adjusted.

The contract with the amalgamated association under the agreement made at the annual conference expires on the 30th of June in each year, and sometimes it has proved impossible to reach an agreement upon the terms for the coming year by that date. In such a case the mills all close down pending nerotiations, but a strike is not declared until the representatives of the manufacturers and of the workmen fail to agree and adjourn without date. Sometimes the negotiations have kept up for over a month after the mills have closed down, and still no strike takes place. This method preserves the funds of the union, as no strike benefits are paid until negotiations are broken off.

During the time that this system of adjustment of differences has been in operation-since 1892 -in but one of the many differences which have arisen has there been a failure to arrive at an adjustment, and there has been but one strike through a disagreement where the nogotiations have been 
conducted by the adjuster. He has been able to prevent many troubles for the men and many petty strikes which would otherwise have caused much annoyance to the manufacturers.

Being an ironworker himself, the adjuster knows the difficulties with which the workmen have to contend, and from his position in the employ and the confidence of the manufacturers, he receives from them full explanations of their side of the question in dispute. On this account he is prepared to give the workmen the employer's' side of the question, and, as he discusses it with them from a practical rather than a business standpoint, he can usually state it in a way that appeals to them more than if the employer himself were to lay it before them.

Many employers have not the patience to listen to and argue a point with an employee. They firmly believe themselves to be in the right and cannot understand why the employee does not grasp the situation and see it as they do. The average workman only wants what is fair and right, but often it requires time and patience to demonstrate the right to him. In these adjustments the result of the deliberations is generally in the nature of a compromise, as there is almost always right on both sides which has to be respected.

Both the employers and the employees seem to be very well satisfied with this method of adjustment of differences. This is shown on the part of the employees by the fact that the officers of the union have often notified the adjuster that they have been called to a certain mill before he has been notified by the firm, and by the further fact that in certain instances the workmen have left it to his decision, in case of disputes, thereby putting him on his honour to deal fairly with both sides.

Experience in the methods employed to adjust disputes between the ironworkers and the manufacturers has brought me to the conclusion that this system, as here described, is by no means perfect, but is, at the same time, a great improvement upon the methods adopted by a good many labour organisations. When once the scale of wages agreed on is signed, it is quite certain that the mills will run for the year 
without interruption, so far as labour difficulties are concerned; for if any difficulty arises the rules of the amalgamated association provide that work shall be continued pending an investigation by both parties to the controversy, and for this reason most of the disputes lose that bitterness which is caused by the sudden stoppage of the works. Such a stoppage seriously interferes with the plans of the employers, and always causes more or less serious financial loss to both parties to the controversy.

As has been stated, the contract between the manufacturers and the workmen expires on June 30 of each year, and if an agreement is not arrived at by that time, all mills controlled by the Amalgamated Association stop work until an agreement is reached. This plan has several faults, in that it often interferes with the placing of contracts that run past July 1, and in that way discriminates against the employer who recognises organised labour and in favour of the one who does not. Again, by stopping work a large body of men who have no interest in the result of the negotiations, and will not be benefited, no matter what the result may be, are thrown ont of work, and these very men are the poorest paid of all labourers in the mill, and can ill afiord to live in enforced idleness.

It would be much better could work be continued until an agreement was reached or negotiations broken off. If this could be done, and then on the failure of negotiations the matter in dispute referred to arbitration, both parties to abide by the decision, it seems as though we should come about as near to a solution of the labour problem as we can expect to do so long as human beings are actuated by the same selfish motives that they are to-day.-Bulletin of the Department of Labour, No. 28, May, 1900.

4. Agreejent for 1901-1902 between the Anerican Tin Plate Company and the Tin Plate Worleers' Association.

Scale of Prices, 1901-1902.

We, the American Tin Plate Company, parties of the first part, and the Tin Plate Workers' International Protective 
Association of America, parties of the second part, do hereby agree that in all mills recognised by the parties of the first part as now organised, the following scale of prices shall govern the wages of employees, commencing July 16, 1901, and ending July 15, 1902.

Section 1. Tinners shall receive on Jumbo stacks $5 \frac{1}{8}$ cents per box and risers $3 \frac{5}{15}$ cents per box for all plates occupying over 36 inches of the rolls. For all plates occupying 36 inches and less of the rolls, tinners shall receive $6 \frac{7}{8}$ cents per hox and riser's $4 \frac{5}{8}$ cents per box.

[Numerous details as to special classes of work omitted.]

Section 12. That all rates shall be advanced 5 per cent. for the following employees:--

Plate wheelers earning less than $\$ 2.00$ per day.

Assorters earning less than 1.25 per day.

Boxers, shearmen, and pickling hands earning less than 1.75 per day.

Scrapers, gatherers, branners, floor sweepers, janitors, tin-house greasemen, palm oil, metal, storehouse, and lime men, and all truckers in and around tin house and assorting room earning less than $\$ 1.45$ per day.

Reckoners earning $\$ 1.15$ per day and less.

It being understood that there shall be no advances on 1900-1901 scale rates for the following: cranemen, bosh truckers, tin weighmen, cold-roll and annealing department employees.

That men working on scruff furnaces at American and Anderson works shall be paid $\$ 1.52$ per day.

Section 13. That, at the option of the American Tin Plate Company, a box or tonnage rate not in excess of the adjusted day rate may be fixed to govern all operatives named in Clause 12.

This box or tonnage rate to be established locally by the district manager representing the American Tin Plate Company, and the national president and district vice-president representing the Tin Plate Workers' International Protective Association.

Section 14. It is further agreed to that no tinner shall be 
required to tin plates on Saturday later than 12 noon or earlier than 5 o'clock on Monday morning.

Section 16. The American Tin Plate Company shall, in such works as it deems expedient, arrange that eight hours shall constitute a day's work on all timning machines, it being agreed, however, that where the eight-hour system at present obtains it shall be continued, and that where two turns of ten hours each are worked the turns shall not be increased.

Where two turns exceeding ten hours are worked the day turn shall be reduced to ten hours and the night turn to eleven hours, and the turns shall alternate.

Section 17. The rates for openers shall be the same as those in scale 1900-1901, it being agreed that the parties of the first part shall handle all iron, both before and after being opened in the Indiana and Muskegon mills.

Section 18. 2,240 pounds shall constitute a ton.

Section 19. That in case of disagreement between the workmen and the foreman the appeal shall be to the mill superintendent. In case of no agreement, the workmen shall appeal to their committee, who shall submit the matter to the local management. In case no local settlement can be effected, the question shall be referred to the district executive committee of the Tin Workers' Union, who shall confer with the district manager. Should no settlement be reached and a strike be deemed necessary by the party of the second part, before such strike is declared the question shall be finally submitted by the Tin Workers' national executive committee to the manufacturers' executive committee, and in case of disagreement ten days' notice of intention to strike shall be given, and work shall be continued in the interim, it being distinctly agreed that no strike shall occur unless aforesaid mode of procedure be followed. Should a strike occur, without such procedure having been followed, this entire agreement shall be considered null and void.

Section 20. That foremen and assistant foremen of all departments governed by this contract, including head annealers, pickers, and cold rollers, shall not be eligible as 
members of the Tin Plate Workers' International Protective Association of America.

Scction 21. That the parties of the second part shall appoint a mill committee on each turn, who, in connection with the superintendent or manager, shall investigate all complaints and will be allowed in all departments of the works for such purpose.

\section{Footnotes.}

(a) That in all mills where tinners do not run their own patches and same are collected and run on certain stacks the rates shall be $27 \frac{1}{2}$ cents per hour for timners and 20 cents per hour for risers, the management of the works of the American Tin Plate Company reserving the option of requiring the tinners and risers to work all of their own patches on their own thinning machines at the box rate as fixed and agreed in the scale for year commencing July 16, 1901.

(b) In cases where the employees under the jurisdiction of this association are required to stay in the mill longer than two and one-half hours on account of breakage or shortage of material they shall be paid $16 \frac{2}{3}$ cents per hour after that time.

(c) Tinners, redippers, and risers shall be paid for all primes, and wasters.

The American Tin Plate Company, By Warner Arus, Second Vice-President.

Tin Plate Workers' International Protective Association, By Geonge Powell, President.

$$
\text { Appendix. }
$$

The following are the verbal agreements entered into by and between the representatives of the American Tin Plate Company and the representatives of the Tin Plate Workers' International Protective Association of America.

It is understood by both parties to this contract that the advances named in clause 12 are to apply to employees only who are members of the Tin Plate Worhers' International Protective Association. 


\section{REPORT AND AWARDS OF THE ANTHRACITE COAL STRIKE COMMISSION.}

To the President, - -

Washington, D.C. : March 18, 1903.

The undersigned, constituting the Commission appointed by you October 16, 1902, "at the request of both the operators and of the miners,' ' to inquire into, consider, and pass upon the questions in controversy in connection with the strike in the anthracite regions' of Pennsylvania, 'and the causes out of which the controversy arose,' have the honor to make to you and, through you, to the parties to the submission the following report, findings, and award:

The authority of the Commission . . . to make a binding award is found in the letter of certain of the anthracite coal operators addressed to the public a few days prior to the said 16 th of October, 1902; in your telegram of that date to Mr. John Mitchell . . . and in his reply, with the subsequent action of the employees of the various coal companies engaged in operating mines in the anthracite coal fields of Pennsylvania, as represented in a convention held at Wilkesbarre, Pa., October 21, 1902, certified to you by the officers of said convention.

In this respect the pertinent parts of the correspondence aforesaid are as follows:

Extract from Coal Operators' Letter relative to Submission.

We suggest a Commission be appointed by the President of the United States (if he is willing to perform that public service) to whom shall be referred all questions at issue between the respective companies and their own employees, whether they belong to a union or not, and the decision of that Commission shall be accepted by us.

The Commission to be constituted as follows: 
1. An officer of the engineer corps of either the military or naval service of the United States.

2. An expert mining engineer, experienced in the mining of coal and other minerals and not in any way connected with coal mining properties, either anthracite or bituminous.

3. One of the judges of the United States courts of the eastern district of Pennsylvania.

4. A man of prominence eminent as a sociologist.

5. A man who by active participation in mining and selling coal is familiar with the physical and commercial features of the business.

It being the understanding that immediately upon the constitution of such Commission, in order that idleness and non-production may cease instantly, the miners will return to work, and cease all interference with or persecution of any non-union men who are working or shall hereafter work. The findings of this Commission shall fix the date when the same shall be effective, and shall govern the conditions of employment between the respective companies and their own employees for a term of at least three years.

Geo. F. Baer,

President Philadelphia and Reading Coal

and Iron Company,

Lehigh and Wilkesbarre Coal Company,

Temple Iron Company.

E. B. Thomas,

Chairman Pennsylvania Coal Company,

Hillside Coal and Iron Company.

W. H. Truesdale,

President Delaware, Lackawanna and

Western Railroad Company.

T. P. Fowler,

President Scranton Coal Company,

Elk Hill Coal and Iron Company.

R. M. Olypirant,

President Delaware and Hudson Company.

Alfred Walter,

President Lehigh Valley Coal Company. 
Telegram of the President to John Mitehell.

White Hocse, Wasingatox: October 16, 1902.

Мв. Јонn Mrtcheld, President United Mine Workers

of America, Williesbarre, Pa.:-

I have appointed as commissioners Brig. Gen. John M. Wilson, Mr. E. W. Parker, Judge George Gray, Mr. E. E. Clark, Mr. Thomas H. Watlins, and Bishop John L. Spalding, with Hon. Carroll D. Wright as recorder. These names are accepted by the operators, and I now most earnestly ask and urge that the miners likewise accept this Commission. It is a matter of vital concern to all our people, and especially to those in our great cities who are least well off, that the mining of coal should be resumed without a day's unnecessary delay.

Theodore Roosevelt.

Extract from Letter of John Mitchell to the President.

Wilkesbafre, Pa.: October 16, 1902.

Hon. Theodone Roosevelt, President of the United States, Washington, D.C.

Dear Sir,-

Replying thereto [to the above telegram], I beg to inform you that your recommendations were submitted to the members of the executive boards of districts 1, 7, and 9, United Mine Workers of America, and they have unanimously agreed to call a delegate convention, to be held next Monday, and will recommend to the convention that all men now on strike return to the positions and working places formerly occupied by them, and submit to the Commission appointed by you all questions at issue between the operators and mine workers of the anthracite coal fields.

John Mrtchell, President United Mine Workers of America. 
Action of the Mine Workers' Representatives in Convention, agreeing to the submission, as certified by the officers of said Convention.

Wilmesbarre, Pa.: October 21, 1902.

Hon. Theodore Roosevert, President of the United States, Dear Sir,Washington, D.C.

We, the representatives of the employees of the various coal companies engaged in operating mines in the anthracite coal fields of Pennsylvania, in convention assembled, having under consideration your telegram of October 16, 1902, addressed to John Mitchell, President United Mine Workers of America, have decided to accept the proposition therein embodied and submit all the questions at issue between the operators and mine workers of the anthracite coal region for adjustment to the Commission which you have named. In pursuance of that decision we shall report for work on Thursday morning, October 23, in the positions and working places occupied by us prior to the inauguration of the strike. We have authorised John Mitchell, President of the United Mine Workers of America, with such assistants as he may select, to represent us in all hearings before the Commission.

Jolin Mitcheli, Chairman of Convention. W. B. Wilson, Secretary of Convention.

It will thus be seen that the Commission is authorised by two parties to a controversy to make, as to them, a binding award. ...

Mr. Carroll D. Wright having been, with the consent of both sides, added to the Commission, the undersigned received from you the following letter :

President's Appointment of the Commission.

Vhite Hodse, Washington: October 23, 1902.

To the Anthracite Coal Strike Commission.

Gentlemen,--

At the request both of the operators and of the miners, I have appointed you a Commission to inquire into, consider, 
and pass upon the questions in controversy in connection with the strike in the anthracite region, and the causes out of which the controversy arose. By the action you recommend, which the parties in interest have in advance consented to abide by, you will endeavour to establish the relations between the employers and the wage workers in the anthracite fields on a just and permanent basis, and, as far as possible, to do away with any causes for the recurrence of such difficulties as those which you have been called in to settle. I submit to you herewith the published statement of the operators, following which I named you as the members of the Commission.

Theodore Poosevelt.

The Commission caused letters to be sent in its name to all the coal companies and individual operators of the anthracite region of Pennsylvania not already parties to the submission, inviting them severally to become parties, by intervention and agreement to be bound by the award to be made, and by filing written notice to that effect with the recorder of the Commission.

The following list comprises all the independent operators, so called, known to the Commission, and to whom the letter cited above was sent:

[74 names follow.]

From time to time during the progress of the hearings interventions were made by the parties as named above, and they were added to the original signatory companies proposing the submission. The following independent or individual operators, some of whom filed answers and all of whom agreed to abide by the award of the Commission, were represented by counsel :

[41 names follow.]

The following companies stated their willingness to abide by the award of the Commission, but were not represented before it by counsel or otherwise:

[10 names follow. 
Upon the opening of the hearings an application to be heard before the Commission was presented by Messrs. Lenahan and O'Brien, as counsel for certain non-union mine workers. . . It was ordered that the counsel aforesaid file their authority for their appearance, together with an agreement to be bound by the award of the Commission. In compliance with this order, a power of attorney executed by more than two thousand persons, representing themselves to be nonunion mine workers, was filed, with an agreement on their part to be bound by the award ; and in the subsequent proceedings said counsel appeared and took part. . . .

The total number of witnesses examined before the Commission was 558. . . . The record of testimony makes 10,047 pages, besides a vast quantity of exhibits, statistics, and other pertinent matter.

\section{Demands of the Mine Workers.}

... For the purpose of securing an orderly procedure, the Commission ordered that the mine workers should be considered as the pursuing party, and they accordingly opened and closed the case. It also required that their statement of claims should be specifie enough to give fair notice to the other side of the grievances complained of, and of the general contentions to be urged in the premises.

The statements so filed on behalf of the mine workers disclosed four general demands, accompanied by specific arguments in support of the same. All the original parties and many of the intervening parties filed answers to this statement of claim. . . .

The demands in the statement of claim made by the union mine workers are as follows:-

First. An increase of 20 per cent. upon the prices paid during the year 1901 to employees performing contract or piece work.

This demand is made on account of the following reasons:

1. The present rate of wages is much lower than the rate 
of wages paid in the bituminous coal fields for substantially similar work.

2. The present rate of wages is lower than is paid in other occupations requiring equal skill and training.

3. The average annual earnings in the anthracite coal fields are much less than the average annual earnings in the bituminous coal fields for substantially similar work.

4. The average annual earnings in the anthracite coal fields are much less than the average annual earnings for occupations requiring equal skill and training.

5. The rate of wages in the anthracite coal fields is insufficient to compensate the mine workers in view of the dangerous character of the occupation, in relation to accidents, the liability to serious and permanent disease, the high death rate and the short trade life incident to this employment.

6. The annual earnings of the mine workers are insufficient to maintain the American standard of living.

7. The increased cost of living has made it impossible to maintain a fair standard of life upon the basis of present wages, and has not only prevented the mine workers from securing any benefit from increased prosperity, but has made their condition poorer on account of it.

8. The wages of the anthracite mine workers are so low that their children are prematurely forced into the breakers and mills instead of being supported and educated upon the earnings of their parents.

9. Wages are below the fair and just earnings of mine workers in this industry.

Second. A reduction of 20 per cent. in hours of labor without any reduction of earnings for all employees paid by the hour, day, or week.

The second demand is similar to the first in that it is designed to increase the hourly rate of wages of mine workers employed by the hour, day or week, and all the reasons applicable to the first demand are asked to be applied to the second without repetition.

In addition thereto we submit the following :-

10. The ten-hour day is detrimental to the health, life, safety, and well-being of the mine workers. 
11. Shorter hours improve the physical, mental, and moral condition of the workers.

12. Shorter hours increase the intensity and efficiency of labor.

13. The tendency of national and State governments, of organised trades and of production generally, is towards shorter hours.

14. A working day of eight hours is sufficiently long for the best interests of the worlingmen and of the community.

Third. The adoption of a system by which coal shall be weighed and paid for by weight wherever practicable; the minimum rate per ton to be 60 cents for a legal ton of 2,240 pounds; the differentials now existing at the various mines to be maintained.

This demand is made on account of the following reasons:-

1. Measurement by the legal ton wherever practicable is the only honest and just system of measuring the earnings of the mine workers.

2. When the operators sell or transport coal it is on the basis of a legal ton of 2,240 pounds.

3. The excessive ton was originally intended to compensate the operator for the weight of the small sizes of coal which were then discarded, but which are now utilised and sold, and therefore there is no present necessity for the use of any other than the legal ton.

4. The adoption of this system would remove an incentive, both to the operator and the worker, to cheating and dishonesty, and would allay jealousy among the miners and prevent unjust discrimination and favoritism.

(5) The change of the present system to the one asked for would prove a strong factor in allaying suspicion and discontent amongst the mine workers.

Fourth. The incorporation in an agreement between the United Mine Worker's of America and the anthracite coal companies of the wages which shall be paid and the conditions of employment which shall obtain, together with satisfactory methods for the adjustment of grievances which may arise 
from time to time, to the end that strikes and lockouts may be unnecessary.

In support of this demand we submit the following reasons :

(1) The anthracite mine workers should not be compelled to make or sign individual agreements, but should have the right to form such organisation and choose such agents and officers as they desire to act collectively instead of individually whenever they deem that their best interests are subserved thereby.

(2) Agreements between employers and employees through workingmen's organisations are the ordinary method of regulating production and wages in the bituminous coal fields and in other large industries, and are beneficial, successful, and in keeping with the spirit of the times.

(3) Unions of workingmen tend to better discipline of the men and to the improvement of their physical, moral, and mental condition, and to the preservation of friendly relations between employer and employee.

(4) Experience shows that the trade agreement is the only effective method by which it is possible to regulate questions arising between employers and employed in large industries, and that is trade agreement is the only possible way 'to establish the relations between employers and the wage workers in the anthracite fields on a just and permanent basis, and as far as possible to do away with any causes for the recurrence of such difficulties as those you (the Anthracite Coal Strike Commission) have been called in to settle.'

\section{Answer's of Mine Operaturs.}

To these demands and the reasons in support thereof the several answers of the operators nnake general and specific denial. No good purpose would be accomplished by here reciting even a summary of these answers on this point, even if their volume did not forbid. These answers all agree in characterising the demands as unreasonable and unjust, and unsupported by facts. . . .

These claims and contentions on the part of the mine workers and the answers thereto, together with the testimony 
in their support . . have been considered by the Commission, with the following results:-

\section{Findings of thit Comuission.}

1. Demand for Higher Wages for Contract Miners.

The Commission finds that the conditions of the life of mine workers outside the mines do not justify, to their full extent, the adverse criticisms made by their representatives, in their contentions at the hearings and in their arguments before the Commission in support of the proposition 'that the amnal earnings of the mine workers are insufficient to maintain the American standard of living.' . . .

The contention that the increased cost of living has made it impossible to maintain a fair standard of life, ... and has not only prevented the mine workers from securing any benefit from increased prosperity and from the increase in wages made in 1900, but has rendered their condition poorer, cannot be fully allowed in the terms in which it is made, although the increased cost of living since 1900 is an element that has been carefully considered. This increase for the past few years, as ascertained by an investigation made by the United States Department of Labor, . . . and taking into consideration the leading articles of consumption for food, amounts to 9.8 per cent. A summary of this investigation . . . will be found in the appendix. . . From this it will be seen that, taking the average quantity of articles consumed per family and assuming prices for 1901 to be 100, in 1898 they were 96.5 ; in $1899,94.5$; in $1900,96.7$, and in 1902 , 106.2, the relative increase in cost between 1900 and 1902, therefore, heing as stated, 9.8 per cent. These conclusions are based on retail prices secured by special agents of the Department of Labor from fifty-eight establishments, representing thirteen rities or towns in the anthracite regions, and are trustworthy so far as they go....

Statisties of this lind, however, are rather too inexact for a satisfuctory basis on which to make precise calculations when considering the question of an increase of wages, for there are some elements entering into the ascertainment of 
an average rise of prices in such a period as that we are considering, which are temporary in their effect. . . . We may cite the rise in price of one of the prime necessaries of life-meat-during 1902, which was sudden and serious and which had its effect on other prime necessaries, and yet recent experience has demonstrated its temporary character.

Another contention of the miners, to wit, that the wages of contract miners are necessarily so low that their children are prematurely forced into breakers and mills, has not been fully sustained, and the Commission does not think that the testimony warrants it in finding as a fact the allegations so made.

So much is said on these points, because a disproportionate length of time was occupied in giving testimony, and in making arguments before the Commission in regard to them, and it is desired to dispose of them here, that we may consider more closely the more important factors that should influence a proper judgment as to the merits of the demand made for higher wages.

As to the general contention that the rates of compensation for contract miners in the anthracite region are lower than those paid in the bituminous fields for work substantially sirnilar, or lower than are paid in other occupations requiring equal skill and training, the Commission finds that there has been a failure to produce testimony to sustain either of these propositions.

As to the bituminous fields, we have no satisfactory evidence upon which to base a comparison between the standard of earnings there and in the anthracite fields, neither miner's nor operators adducing evidence upon which an intelligent judgment on that point might be formed. There was, however, a good deal of testimony upon the second proposition, that the present rates of compensation in the anthracite region are lower than those in other occupations requiring equal skill and training. It is difficult to institute a comparison, owing to the fact that the contract miners, who constitute approximately 26 per cent. and their laborers 18 per cent. of the mine workers, are paid according to contract-so much for a given amount of coal produced. As to this class, 
of course, the conditions on which a rate of daily or monthly earnings depends are so variant that a deduction of a uniform daily or monthly rate can not well be obtained or expected.

To some extent the contract miner has within his own control the number of hours he shall work each day, and consequentiy the amount of work he shall perform. He is paid by the mine car, yard, or ton for the coal he blows down, the loading of which into the mine car is generally the work of a laborer, who is paid by the contract miner, who also pays for powder, oil, and tools, so that in many respects he may be called an independent contractor. For our present purpose it is important to ascertain, first, the net earnings he is able to malie for the day or the year, and, second, what he actually does make. We find some, though not a great, difference in the answers to these two inquiries. It is not surprising to find that there is much difference in the annual earnings of such miners. Experience, natural capacity, aptitude for the rork, individual industry, and habits of sobriety materially affect the amount that is earned.

In addition to these causes of difference, which are more or less in the control of the miner, there are others inherent in the nature of the work, which, though there is a tendency to overcome them by differential rates of payment and by allowances, still constitute serious obstacles to uniformity in the miners' monthly or yearly earnings. Such are the variation in thickness and pitch of the coal seams, faults, and the greater or less impurity of the coal owing to the presence of rock, slate, and other foreign substances. Although there is an endeavor, as has been said, to overcome these difficulties by allowances, there still must remain, when the best has been done, inequality arising from these causes in the aggregate yearly earnings of the miner.

Compilations have been made, at the request of the Commission, by the various operators, parties to the submission, showing the gross and net earnings of the contract miners, practically covering the year 1901. These compilations, with the tables of wages paid all mine workers, have been prepared at great expense, and have been accepted, for the most part, 
by the representatives of the miners as showing truly what they purport to show....

It is readily seen from what has been said that the diffculty of comparing the rate of earnings of contract miners with the rate of wages paid in other occupations requiring equal skill and training is serious.... In attempting a comparison with other occupations, we are met at once with the embarrassing condition that in such occupations the rate of wages paid by the day or the month is uniform, and the labor is generally continuous throughout the year, while in the work of contract miners, who are paid by the yard, car, or ton, the number of days or hours represented by the earnings is a varying quantity, and the number of days in which he is actually employed at all, may be much ferrer than the average number of days constituting a year's work in most other employments.

We have already said that the personal element constantly enters into the case. The miner who by special aptitude or training knows how to economise powder and other supplies, and who is willing to devote two or three hours more a day than the average to his work, can and does make a larger income than his fellows who fail in these respects. Nevertheless, we have ... made some comparison and have sought to arrive at such general results as would fairly represent the average earnings of the contract miner. We have endeavoured to base our judgment, not upon semi-monthly or monthly returns, but upon the earnings of those who have labored throughout the year, only a part of whom may have availed themselves of all their opportunities.

It is impossible to be accurate in this matter. The conditions that make accuracy impossible are inherent in the nature of the subject with which we are dealing. Neither contract miners nor mine workers can work the full number of days in a year which it is possible to work in other callings; that is to say, owing to causes beyond the control of either miner or operator-such as breakage of machinery inside or outside the mine, disarrangement of pumps, storms, repairs, \&c.--opportunity to work in the mines, without fault of either operator or miner, does not present itself on each working day of the year. On the other hand, for causes 
within the control of the operator or miner, the number of idle days at the mines is, or may be, increased.

Talie for example the year 1901, a year of more than usual activity in mining operations, the average number of days throughout the region on which work was started was approximately 260 . The number may have been less. So that the yearly income of the contract miner, as well as that of the others, is the product of work done in parts of days fewer by fifty than the number of working clays in the year ; and for the contract miner the hours worked in each of the days in which a start is made, are fewer than 10, and from the evidence we feel warranted in saying that they certainly do not exceed, on the average, eight hours, there being much testimony to show that many of the miners go into the mines between six and seven in the morning and come out before two o'clock in the afternoon. This is a fact, of course, to be taken into consideration in determining a fair rate of compensation or a fair amnual earning.

We find that the average daily rate of earnings, as nearly as can be ascertained, does not compare unfavourably with that in other industries requiring substantially equal skill and training. It is more instructive, of course, to compare anmual earnings of the contract miner with the annual earnings of those employed in other occupations. We find that these annual earnings of contract miners, based upon returns for the year 1901, range between $\$ 550$ and $\$ 600$. Perhaps it would be safe to put the average at $\$ 560$.

We have also considered the contention ... that the mining industry is perilons and extra hazardous, and find that it should be classed as one of the dangerous industries of the country, ranling with several of the most dangerous. The statistics so far available do not show a greater hazard than obtains in some other occupations, notably in the fisheries and in those of switchmen and freight-train crews on our railroads. Still, the requirements are exacting, and this fact has been duly weighed by the Commission, in coming to a decision upon the demand for an increase in the rate of compensation of contract miners.

Reviewing the whole case, and acting upon the conviction 
produced by the hearing of testimony, and the examination of statistics, the Commission is of the opinion that, in view of the interruptions incident to mining operations, the increased cost of living, the uncertainty as to the number of days during the year presenting an opportunity for work, and the inequalities of physical conditions affecting the ability to earn, and not overlooking the hazardous nature of the employment, some increase in the rate of compensation to contract miners should be made.

The Commission, therefore, considers, and so adjudges and awards :

[See No. 1 under 'Recapitulation of Awards' below. The Report on the next two demands is here omitted. The Awards relative to each will be found below.]

4. Demand for an Agreement with United Mine Worliers of America.

The fourth and last demand of the miners is as follows:

The incorporation in an agreement between the United Mine Workers of America and the anthracite coal companies of the wages which shall be paid and the conditions of employment which shall obtain, together with satisfactory methods for the adjustment of grievances which may arise from time to time, to the end that strikes and lockouts may be unnecessary.

The Commission is constrained to decline making an award which would compel an agreement by the operators with the United Mine Workers of America; for howerer importantly that order may have participated in the strike which was inangurated on May 12 last, and in its subsequent conduct, it is not a party to this submission. It was distinctly stated at the first meeting of the Commission, that the president of the United Mine Workers of America appeared before the Commission as the representative of the mine workers in the anthracite region, on whose behalf had been made the demands which have since been incorporated in the formal statement of claim filed. It is the striking anthracite mine workers, who appear before the Commission as the pursuing party. It is true that they have been represented, and ably 
represented, before the Commission by Mr. Mitchell, but in so representing them he appeared ' as the representative of the anthracite coal mine workers,' and not in his official character as president of the United Mine Workers of America. :

Nor does the Commission consider that the question of the recognition of the United Mine Workers of America is within the scope of the jurisdiction conferred upon it by the submission... .

The Commission feels, however, that it is incumbent upon it to give some expression to its views on the general question. From the correspondence which passed between the coal operator's and the officer's of the United Mine Workers prior to the strike, . . f from the voluminors testimony presented during the hearings, . . . and from the arguments of counsel and others,... the Commission is led to the conviction, that the question of the recognition of the union and of dealing with the mine workers through their union, was considered by both operators and miners to be one of the most important involved in the controversy. . . .

The order, as its name implies, is in organisation to membership in which all workers who "produce or" handle coal or coke in or around the mines' are eligible. It claims a

' At the hearing before the Commission on October 27, Mr. Baer, representing the Philadelphia and Reading Coal and Iron Company, made the following statement :-

- I am anxions to have one thing clearly understood, because it may lead to complications, and it might as well be stated now as at any other time. We have no objection to Mr. Mitchell appearing here to represent miners in the Schuylkill region; but under the terms of the submission to you we have expressly excluded the miners' organisation, because it is a bituminous organisation partly, and we can not consent to Mr. Mitchell's appeariug bere as the representative and as the president of that organisation. So far as he appears bere to represent any of the miners in the anthracite region that are in our employ, we have no objection, and we raise no question about it; but we do not want him to appear on the record as president of the United Mine Workers, becanse we have distinctly stated in the paper from which you have derived your anthority to the President that we will not deal with that organisation.'

In reply to the foregoing, Mr. Mitchell said :

'As to the natter of my status before the Commission, I desire to say that the objections that have been filed are not involved. I appear here as the representative of the anthracite coal mine workcrs.' 
jurisdiction coextensive with the coal-producing industry in America. Its purpose, as stated in its constitution, is to unite the mine workers and 'ameliorate their condition by methods of conciliation, arbitration, or strikes.' The members of the union assert, that they have a right to form themselves into a union, choose their officers, and delegate to those officers authority to represent and speak or bargain for them. They contend that if a majority of the employees of a colliery, or a mining company, are members of the union, the union has a right to negotiate for the services of the employees of that colliery or company, in their collective capacity.

The operators assert that they have no objection to their employees joining a union or labor organisation. They say their refusal to recognise and deal with the United Mine Workers, as at present constituted, is based on the fact that the majority of the members of the union are employed in the bituminous coal fields; that the officers are chiefly from those fields and not well acquainted with the work of mining anthracite coal ; that to deal with them would be dealing with an organisation which is controlled by men engaged in a rival industry, bituminous and antlrracite coal mining being considered by them as competitive or rival industries, so far as the use of anthracite for steam-producing purposes is concerned. The assertion is made that operators in bituminous fields contributed liberally to the striking anthracite miners, in order to continue the advantages which accrued to the bituminous coal industry from the suspension of work in the anthracite region; and it is also alleged and proved, that the local unions in the anthracite fields are, to some extent, controlled by the votes of young boys, who are admitted to membership and who are, throngh their youth and lack of experience, wanting in judgment, and, so far, irresponsible.

Great stress is laid upon the accusation that the United Mine Workers' union resorts to and encourages lawlessness and violence in its efforts to accomplish its purposes or ciesires.

The demands of the mine workers having been made through their union, any adjustment which might have been effected between the operators and the officers of the organisa- 
tion would have carried with it more or less direct recognition of the union. The agreement to submit the disputed points to the decision of this Commission was subscribed to by the presidents of the large anthracite mining and transportation companies on the one side, and by a convention of anthracite mine workers, members of the union, on the other. The submission provides that this Commission shall determine the questions at issue between the several operators and 'their respective employees, whether the latter belong to a union or not,' and shall fix the rate of wages and hours and conditions of labor for a period of not less than three years.

Whatever the jurisdiction of this Commission under the submission may be, the suggestion of a working agreement between employers and employees embodying the doctrine of collective bargaining is one which the Commission believes contains many hopeful elements for the adjustment of relations in the mining regions, but it does not see that, under the terms of the submission from which the powers of the Commission are derived, such an agreement can be made to take the place of, or become part of, its award.

In the days when the employer had but few employees, personal acquaintance and direct contact of the employer and the employee resulted in mutual knowledge of the surrounding conditions and the desires of each. The development of the employers into large corporations, lras rendered such personal contact and acquaintance between the responsible employer and the individual employee no longer possible in the old sense. The tendency towards peace and good-fellowship which grows out of personal acquaintance or direct contact should not, however, be lost through this evolution to greater combinations. There seems to be no medium through which to preserve it, so natural and efficient as that of an organisation of employees governed by rules which represent the rule of a properly constituted majority of its members, and officered by members selected for that purpose, and in whom authority to administer the rules and affairs of the union and its member's is vested.

The men employed in a certain line of work or branch of industry have similar feelings, aspirations, and convictions, 
the natural outgrowth of their common work and common trend or application of mind. The union, representing their community of interests, is the logical result of their community of thought. It encourages calm and intelligent consideration of matters of common interest. In the absence of a union, the extremist gets a ready hearing for incendiary appeals to prejudice or passion, when a grievance, real or fancied, of a general nature, presents itself for consideration.

The claim of the worker that he has the same right to join with his fellows in forming an organisation, through which to be represented, that the stockholder of the corporation has to join others in forming the corporation, and to be represented by its directors and other officers, seems to be thoroughly well founded, not only in ethies but under economic considerations. Some employers say to their employees: "We do not object to your joining the union, but we will not recognise your union nor deal with it as representing you.' If the union is to be rendered impotent, and its usefulness to be nullified by refusing to permit it to perform the functions for which it is created, and for which alone it exists, permission to join it may well be considered as a privilege of doubtful value.

Trades unionism is rapidly becoming a matter of business, and that employer who fails to give the same careful attention to the question of his relation to his labor or his employees, which he gives to the other factors which enter into the conduct of his business, makes a mistake, which sooner or later he will be obliged to correct. . . . Experience shows that the more full the recognition given to a trades union, the more businesslike and responsible it becomes. Through dealing with business men in business matters, its more intelligent, conservative, and responsible members come to the front and gain general control and direction of its affairs. If the energy of the employer is directed to discouragement and repression of the union, he need not be surprised if the more radically inclined members are the ones most frequently heard.

The Commission agrees that a plan, under which all questions of difference between the employer and his 
employees shall first be considered in conference between the employer or his official representative and a committee, chosen by his employees from their own ranks, is most likely to produce satisfactory results and harmonious relations, and at such conference the employees should have the right to call to their assistance such representatives or agents as they may choose, and to have them recognised as such.

In order to be entitled to such recognition, the labor organisation or union must give the same recognition to the rights of the employer and of others, which it demands for itself and for its members. The worker has the right to quit or to strike in conjunction with his fellows, when by so doing he does not violate a contract made by or for him. He has neither right nor license to destroy or to damage the property of the employer; neither has he any right or license to intimidate or to use violence against the man who chooses to exercise his right to work, nor to interfere with those who do not feel that the union offers the best method for adjusting grievances.

The union must not undertake to assume, or to interfere with, the management of the business of the employer. It should strive to make membership in it so valuable as to attract all who are eligible; but in its efforts to build itself up, it must not lose sight of the fact that those who may think differently have certain rights guaranteed them by our free government. However irritating it may be to see a man enjoy benefits to the securing of which he refuses to contribute, either morally, or physically, or financially, the fact that he has a right to dispose of his personal services as he chooses cannot be ignored. The non-union man assumes the whole responsibility which results from his being such, but his right and privilege of being a non-union man are sanctioned in law and morals. The rights and privileges of nonunion men are as sacred to them as the rights and privileges of unionists. The contention that a majority of the employees in an industry, by voluntarily associating themselves, in a union, acquire authority over those who do not so associate themselves is untenable.

We believe it is unwise and impolitic to permit boys of 
immature age and judgment to participate in deciding the policy and actions of a labor union. We think that no one should have such voice in the affairs of a union until he has reached his legal majority .. . This does not mean, of course, that minors should not belong to the union, but they should not act as, nor vote for, delegates to conventions which consider or determine strikes.

The present constitution of the United Mine Worker's of America does not present the most inviting inducements to the operators to enter into contractual relations with it. Minors are represented in conventions called for the consideration of strikes; while boys do not go as delegates, only one case having been noted, they send delegates to such conventions; and as the boys in the union in the anthracite region constitute about 20 per cent. of the membership, it is easily seen that their representatives, who may be obliged to act on instructions, may have the balance of power, and thus carry a vote for a strike when the more conservative and experienced members might be opposed to it.

Under the recently amended constitution of the United Mine Workers of America, strikes must originate with the locals or districts; but before final action is taken by any district upon questions that directly or indirectly affect the interests of the mine workers of another district, or that require a strike to determine such questions, the president and secretary of the aggrieved district must jointly prepare, sign, and forward to the national president, a written statement setting forth the grievance complained of, the action contemplated by the district, and the reasons therefor; and the national president must, within five days after the receipt of such statement, either approve or disapprove of the action contemplated by the aggrieved district, such approval or disapproval to be made in writing and a copy forwarded to the secretary of the complaining district. If the national president approve, the district is free to act; but should he disapprove the contemplated strike, the district may appeal to the national executive board, which must be convened to consider such appeal within five days after its receipt. Until the national president has approved or the national executive 
board has sustained the appeal, no district is free to enter upon a strike, mnless it be general or national, ordered by a national convention.

These provisions give the districts in the anthracite region quite independent powers relative to the initiation of a strike, and their powers are in a measure safeguarded by the necessity of first securing the approval of the national president, or, in case of his disapproval, of the national executive board. The difficulty does not lie so much in the method now pursued as in the fact that a strike may be undertaken by a majority vote of the members of a district convention called for the purpose of considering the strilie. This is considered a wealness in the present method. Instead of a majority vote there should be at least a two-thirds vote of all the delegates in the convention considering the question of a strike. The vote should be by ballot, and not by voice, or show of hands. An amendment to the constitution, making such provisions as those just indicated, and creating a separate anthracite department, so far as strikes are concerned, would remove some of the serious objections that have been urged by the operators.

An independent and autonomous organisation of the anthracite mine workers of Pennsylvania, however affiliated, in which the oljectionable features above alluded to should be absent, would deserve the recommendation of this Commission, and, were it within the scope of its jurisdiction, the said fourth demand of the statement of claim, for collective bargaining and a trade agreement, might then be reasonably granted.

The Commission has carefully considered and has outlined a plan for an organisation for the execution of trade agreements in the anthracite region,... . which is printed in full as an appendix. ${ }^{1}$

'[Of this 'Plan recommended by the Commission' the following are the most important clauses:--

1. An organisation of anthracite mine workers, governed by the anthracite mine workers and free from control or dictation of bituminous mine workers.

This can be effected by making the anthracite mine workers a separate department of the union, or by such other modification of rules and laws as will best effect the purpose. 
When under the award the parties have faithfully obeyed its terms and thus learned to deal with each other, a trade agreement between operators and an anthracite mine workers' organisation may commend itself to both sides. We believe this, especially when it is considered that in other directions, and in other industries, such agreements have been made

2. All workers in and about the anthracite mines, excepting foremen, assistant foremen, and other bosses, clerks, and office employees, to be eligible to membership in the organisation and entitled to its privileges and benefits; provided that boys under 21 years of age should not have voice or vote on propositions pertaining to strikes.

3. A local body of the organisation for each colliery, composed of the employees of that colliery and officered by officers chosen by them from their own ranks.

4. A local committee in each local, composed of its own members, emplojees of the colliery, whose duty it shall be to seek adjustment at the hands of the local ofticials, of any local complaints which the local may refer to the committee, and which the aggrieved member is unable to adjust with his immediate superior officer.

5. A general committee for each company's employees composed of one representative from each colliery, if there be three or more collieries. If less than three collieries, the general committee to be composed of two or three members from each colliery.

Complaints which local committees are unable to adjust to be referred to the general committee, which should have authority to dismiss or settle the complaint and have their decision binding upon the organisation and its members.

General committees to seek adjustments of complaints at the hands of the general officers of the employing company.

If the general officers of the company and the general committee are unable to reach an agreement, the general committee should have the right to call into the conference, to assist and advise them, such general officer of the organisation as may be selected and to whom such duties are delegated, regardless of whether or now such general officer is an employee of the company interested.

6. Agreements between the organisation and the employers of its members, governing terms or conditions of employment, should provide that any matter in dispute which the general officers of the company and the general committee of the organisation, accompanied by their general officer, are unable to reach an adjustment of shall be submitted to fair arbitration, the award to be accepted by both.

7. No strike to be inaugurated until the committees and officers of the organisation have complied with all their rules and have exhausted all other honorable efforts to reach an agreement and have failed; nor then, until proposal to strike has been submitted to all the members employed in that colliery or by that company who are entitled to vote on strike questions, and two-thirds of them have voted by ballot in favour of the proposal.] 
and adhered to for terms of years, completely avoiding strikes and lahor controversies generally. Of course, here and there in the lituminous regions, these agreements may not have worked with perfect satisfaction to hoth parties, and in some districts they have been abandoned after a brief trial, but on the whole the experience under them in this country, and in England, testifies to their great usefulness in preserving peace and harmony.

The Commission is of opinion, nevertheless, that some satisfactory method for the adjustment of grievances which may arise from time to the the end that strikes and lockouts may be unnecessary, the demand for which as part of an arreement with the United Mine Workers of America is made in the fourth claim, just referred to, should be imposed by its award upon the parties to this submission.

It, accordingly, hereby adjudges and awards :

[Sce No. 4 under 'Recapitulation of Awards' below.]

\section{Sliding Scale.}

The attention of the Commission during the argument was called to a proposition for the establishment of the sliding scale, as a basis of payment or as an adjunct to any general system of payment adopted. It has many attractive features and is, in its essence, a profit-sharing device. The testimony shows that it was in operation for many years in the Lehigh and Schuyllill regions. As it existed in the latter it seems to have given measurable satisfaction. It appears, however, to have had a confessed defect, in that there was no minimum basis of earnings for the miner.

No sliding scale can be of permanent value, unless there be established a minimum basis of earnings, and a minimum price of the article on which the scale is constructed. The statistics of the prices of coal, f.o.b. New York Harbor, have enabled the Commission to arrive at what seems to be a just basis, so far as price is concerned, while the minimum basis of earnings must necessarily be that established in the award.

The Commission has not thought it wise to adopt an arrangement for a sliding scale as a substitute for an increase 
in the compensation of mine workers, and has, accordingly, in its preceding awards, provided for such direct increase as in its judgment is fair to both operator and mine worker, for the period of three years. Therefore, in prescribing the following sliding scale, the Commission does not do so with the expectation that it means any immediate addition to the increases already provided for in the earnings and wages of mine workers, or that it necessarily means an increase at all, but with the thought that if in the future the price of coal should become what might be called abnormally high, there might be participation by miners and mine workers in the profits derived from such inereased price.

The Commission, therefore, adjudges and awards :

[See No. 8 under ' Recajitulation of Awards' below.]

\section{Piecaptuclation of Awards.}

1. The Commission adjudges and awards: That an increase of 10 per cent. over and above the rates paid in the month of April, 1902, be paid to all contract miners for cutting coal, yardage, and other work for which standard rates or allowances existed at that time, from and after November 1, 1902, and during the life of this award; and also to the legal representatives of such contract miners as may have died since November 1, 1902. The amount of increase under the award due for work done between November $\mathbf{1}$, 1902, and April 1, 1903, to be paid on or before June 1, 1903.

2. The Commission adjudges and awards: That engineers who are employed in hoisting water shall have an increase of 10 per cent. on their earnings between November 1, 1902, and April 1, 1903, to be paid on or before June 1, 1903; and a like allowance shall be paid to the legal representatives of such employees as may have died since November 1, 1902 ; and from and after April 1, 1903, and during the life of the award, they shall have eight-hour shiits, with the same pay which was effective in April, 1902; and where they are now working eight-hour shifts, the eight-hour shifts shall be continued, and these engineers shall have an increase of 10 per cent. on the wages which were effective in the several positions in April, 1902. 
Hoisting engineers and other engineers and pumpmen, other than those employed in loisting water, who are employed in positions which are manned continuously, shall have an increase of 10 per cent. on their earnings between November 1, 1902, and April 1, 1903, to be paid on or before June 1, 1903; and a like allowance shall be paid to the legal representatives of such employees as may have died since November 1, 1902 ; and from and after April 1, 1903, and during the life of the award, they shall have an increase of 5 per cent. on the rate of wages which were effective in the several positions in April, 1902; and in addition they shall be relieved from duty on Sundays, without loss of pay, by a man provided by the employer to relieve them during the hours of the day shift.

The Commission adjudges and awards: That firemen shall have an increase of 10 per cent. on their earnings between November 1, 1902, and April 1, 1903, to be paid on or before June 1, 1903 ; and a like allowance shall be paid to the legal representatives of such employees as may have died since November 1, 1902 ; and from and after April 1, 1903, and during the life of the award, they shall have eight-hour shifts, with the same wages per day, week, or month as were paid in each position in April, 1902.

The Commission adjudges and awards: That all employees or company men, other than those for whom the Commission makes special awards, he paid an increase of 10 per cent. on their earnings between November 1, 1902, and April 1, 1903, to be paid on or before June 1, 1903; and a like allowance shall be paid to the legal representatives of such employees as may have died since November 1, 1902 ; and that from and after April 1, 1903, and during the life of this award, they shall be paid on the basis of a nine-hour day, receiving therefor the same wages as were paid in April, 1902, for a ten-hour day. Overtime in excess of nine hours in any day to be paid at a proportional rate per hour.

3. The Commission adjudges and awards: That during the life of this award the present methods of payment for coal mined shall be adhered to, unless changed by mutual agreement. 
4. The Commission adjudges and awards: That any difficulty or disagreement arising under this award, either as to its interpretation or application, or in any way growing out of the relations of the employers and employed, which can not be settled or adjusted by consultation between the superintendent or manager of the mine or mines, and the miner or miners directly interested, or is of a scope too large to be so settled or adjusted, shall be referred to a permanent joint committee, to be called a board of conciliation, to consist of six persons, appointed as hereinafter provided. That is to say, if there shall be a division of the whole region into three districts, in each of which there shall exist an organisation representing a majority of the mine workers of such district, one of said board of conciliation shall be appointed by each of said organisations, and three other persons shall be appointed by the operators, the operators in each of said districts appointing one person.

The board of conciliation thus constituted, shall take up and consider any question referred to it as aforesaid, hearing both parties to the controversy, and such evidence as may be laid before it by either party; and any award made by a majority of such board of conciliation shall be final and binding on all parties. If, however, the said board is unable to decide any questions submitted, or point related thereto, that question or point shall be referred to an umpire, to be appointed, at the request of said board, by one of the circuit judges of the third judicial circuit of the United States, whose decision shall be final and binding in the premises.

The membership of said board shall at all times be kept complete, either the operators' or miners' organisations having the right, at any time when a controversy is not pending, to change their representation thereon.

At all hearings before said board the parties may be represented by such person or persons as they may respectively select.

No suspension of work shall take place, by lockout or strike, pending the adjudication of any matter so taken up for adjustment.

5. The Commission adjudges and awards: That whenever 
requested by a majority of the contract miners of any colliery, check weighmen or check docking bosses, or both, shall be employed. The wages of said check weighmen and check docking bosses shall be fixed, collected, and paid by the miners in such manner as the said miners shall by a majority vote elect; and when requested by a majority of said miners, the operators shall pay the wages fixed for check weighmen and check docling bosses, ont of deductions made proportionately from the earnings of the said miners, on such basis as the majority of said miners shall determine.

6. The Commission adjudges and awards: That mine cars shall be distributed among miners, who are at work, as uniformly and as equitably as possible, and that there shall be no concerted effort on the part of the miners or mine workers of any colliery or collieries, to limit the output of the mines or to detract from the quality of the work performed, unless such limitation of output be in conformity to an agreeinent between in operator or operators, and an organisation representing a majority of said miners in his or their employ.

7. The Commission adjudges and awards: That in all cases where miners are paid by the car, the increase awarded to the contract miners is based upon the cars in use, the topping required, and the rates paid per car which were in force on April 1, 1902. Any increase in the size of car, or in topping required, shall be accompanied by a proportionate increase in the rate paid per car.

8. The Commission adjudges and awards: That the following sliding scale of wages shall become effective April 1, 1903, and shall affect all miners and mine workers included in the awards of the Commission :

The wages fixed in the awards shall be the basis of, and the minimum under, the sliding scale.

For each increase of five cents in the average price of white-ash coal of sizes above pea coal, sold at or near New York, between Perth Amboy and Edgewater, and reported to the Bureau of Anthracite Coal Statistics, above $\$ 4.50$ per ton f.o.b., the employees shall have an increase of 1 per cent. 
in their compensation, which shall continue until a change in the average price of said coal works a reduction or an increase in said additional compensation hereunder ; but the rate of compensation shall in no case be less than that fixed in the award. That is, when the price of said coal reaches 4.55 per ton, the compensation will be increased 1 per cent., to continue until the price falls below $\$ 4.55$ per ton, when the 1 per cent. increase will cease, or until the price reaches $\$ 4.60$ per ton, when an additional 1 per cent. will be added, and so on.

These average prices shall be computed monthly, by an accountant or commissioner, named by one of the circuit judges of the third judicial circuit of the United States, and paid by the coal operators such compensation as the appointing judge may fix, which compensation shall be distributed among the operators in proportion to the tonnage of each mine.

In order that the basis may be laid for the successful working of the sliding scale provided herein, it is also adjudged and awarded: That all coal-operating companies file at once with the United States Commissioner of Labor, a certified statement of the rates of compensation paid in each occupation known in their companies, as they existed April 1, 1902.

9. The Commission adjudges and awards: That no person shall be refused employment, or in any way discriminated against, on account of nembership or non-membership in any labor organisation: and that there shall be no discrimination against, or interference with, any employee who is not a member of any labor organisation by members of such organisation.

10. The Commission adjudges and awards: That all contract miners be required to furnish within a reasonable time before each pay day, a statement of the amount of money due from them to their laborers, and such sums shall be deducted from the amount due the contract miner, and paid directly to each laborer by the company. All employees when paid shall be furnished with an itemised statement of account.

11. The Commission adjudges and awards: That the awards herein made shall continue in force until March 31, 
1906 ; and that any employee, or group of employees, violating any of the provisions thereof, shall be subject to reasonable discipline by the employer ; and, further, that the violation of any provision of these awards, either by employer or employees, shall not invalidate any of the provisions thereof. 


\section{POLITICAL ECONONY \& ECONONICS.}

ECONOMIC STUDIES. By WaLter Bagehot. Crowu 8 vo. $3 s .6 d$.

PRACTICAL SOCIALISM. Essays on Social Reform. By SAMcel A. and Hexrietta BARNeTr. Crown 8vo. $6 s$.

POLITICAL ECONOMY. By Charles S. Devas, M.A. Crown svo. 7s.6d.

LOCAL VARIATIONS IN WAGES. By F. W. La wrence, M.A. With Index and 18 Maps and Diagrams. Merium 4to. $8 s .6 d$.

ESSAYS ON POLITICAL ECONOMY. ByT.E. Cliffe Leslie, Hou. LI.D. Dubl. 8vo. 10s. $6 d$.

POLITICAL ECONOMY. By John Stuart Mill. Popular Edition. Crown 8vo. 3s.6d. | Library Edition. 2 vols. 8 vo. $30 s$.

INDUSTRIES AND WEALTH OF NATIONS. By MICHAEL G. MulHall, F.S.S. With 32 full-page Diagrams. Crown 8vo. $8 s .6 d$.

POLITICAL ECONOMY: a Short Text-book of Politieal Economy. With Problems for Solution. Hints for Supplementury Rearliug, and a Supplementary Chapter ou Sucialism. By J. E. SYMEs, M.A. Crown 8vo. $2 s .6 d$.

LECTURES ON THE INDUSTRIAL REVOLUTION OF THE 18TH CENTTRY IN ENGLAND. Popular Adidresses, Notes, and other Fragments. By Arxold Torisee. With a Memoir of the Author by BexJameN JoWETT, D.D. 8vo. 10s. 6d.

\section{By W. J. ASHLEY.}

ENGLISH ECONOMIC HISTORY AND THEORY. Crown 8vo. Part I., 5s. Part II., 10s. 6 d.

SURVEYS, HISTORIC AND ECONOMIC. Crown 8 vo. $9 s$. net.

\section{By HENRY DUNNING MACLEOD.}

BIMETALISM. 8vo. 5s. net.

THE ELEMENTS OF BANKING. Cr. 8vo. 3s. 6d. THE THEORY AND PRACTICE OF BANKING. Vul. I. 8vo. 12s. Vol. II. 14s.

THE THEORY OF CREDIT. 8vo. In 1 vol. 30s. net; or separately, Vol. I., 10s. net. Vol. II., Part I., 10s. net. Vol. II., Part II., 10s. net.

INDIAN CURRENCY. 8vo. 2s. 6d. net.

BY SYDNEY and BEATRICE WEBB.

THE HISTORY OF TRADE UNIONISM. With Maap and full Bibliography of the Subjeet. $8 v 0.7 s .6 d$. net.

INDUSTRIAL DEMOCRACY : a Study in Trade Unionisn. 8vo. 12s, net.

PROBLEMS OF MODERN INDUSTRY: Essays. 8 vo. 5 s. net.

LONGMANS, GREEN, \& CO., 39 Paternoster Row, London, New York, and Bombay. 
, 


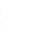


UNIVERSITY OF CALIFORNIA, LOS ANGELES

THE UNIVERSITY LIBRARY

This book is DUE on the last date stamped below

jus

UPL

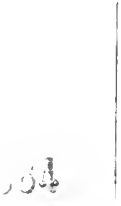

this

F, : I,

$2+-i \quad+140+1+2$

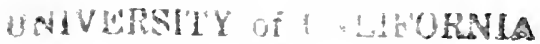

L人S ANGHLES

重IBRABX 
UC SOUTHERN RE GIONAL LIBRARY FACILITY

AA $000906133 \quad 4$ 
